\title{
Forebay Computational Fluid Dynamics Modeling for The Dalles Dam to Support Behavior Guidance System Siting Studies
}

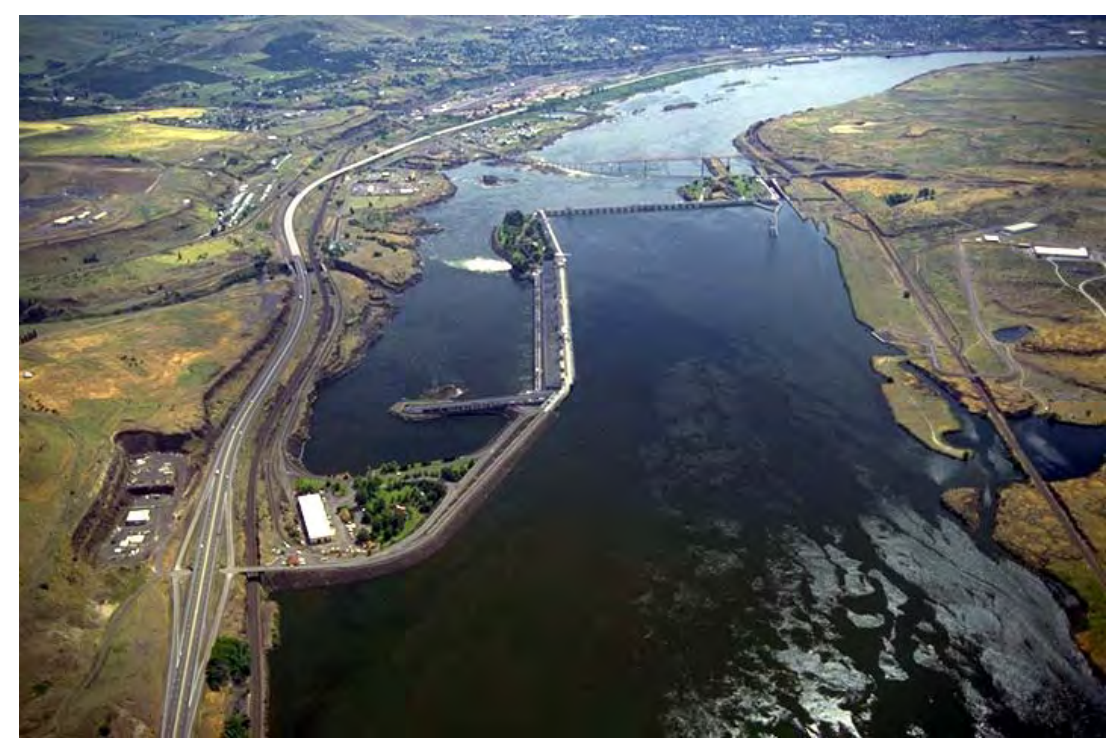

C.L. Rakowski

M.C. Richmond

J.A. Serkowski

G.E. Johnson

Final Report

March 2006

Prepared for the U.S. Army Corps of Engineers

Portland District, Portland, Oregon

Under a Related Services Agreement

with the U.S. Department of Energy

Contract DE-AC05-76RL01830

\section{Pacific Northwest National Laboratory}

Operated by Battelle for the

U.S. Department of Energy 


\title{
DISCLAIMER
}

This report was prepared as an account of work sponsored by an agency of the United States Government. Neither the United States Government nor any agency thereof, nor Battelle Memorial Institute, nor any of their employees, makes any warranty, express or implied, or assumes any legal liability or responsibility for the accuracy, completeness, or usefulness of any information, apparatus, product, or process disclosed, or represents that its use would not infringe privately owned rights. Reference herein to any specific commercial product, process, or service by trade name, trademark, manufacturer, or otherwise does not necessarily constitute or imply its endorsement, recommendation, or favoring by the United States Government or any agency thereof, or Battelle Memorial Institute. The views and opinions of authors expressed herein do not necessarily state or reflect those of the United States Government or any agency thereof.

\author{
PACIFIC NORTHWEST NATIONAL LABORATORY \\ operated by \\ BATTELLE \\ for the \\ UNITED STATES DEPARTMENT OF ENERGY \\ under Contract DE-AC05-76RL01830
}

Printed in the United States of America
Available to DOE and DOE contactors from the Office of Scientific and Technical Information, P.O. Box 62, Oak Ridge, TN 37831-0062;
ph: (865) 576-8401
fax: (865) 576-5728
email: reports@adonis.osti.gov

\begin{abstract}
Available to the public from the National Technical Information Service, U.S. Department of Commerce, 5285 Port Royal Rd., Springfield, VA 22161 ph: (800) 553-6847 fax: (703) 605-6900 email: orders@ntis.fedworld.gov online ordering: http://www.ntis.gov/ordering.htm
\end{abstract}


PNNL-15689

\title{
Forebay Computational Fluid Dynamics Modeling for The Dalles Dam to Support Behavior Guidance System Siting Studies
}

\author{
C.L. Rakowski \\ M.C. Richmond \\ J.A. Serkowski \\ G.E. Johnson
}

Final Report

March 2006

Prepared for the U.S. Army Corps of Engineers

Portland District, Portland, Oregon

Under a Related Services Agreement

with the U.S. Department of Energy

Contract DE-AC05-76RL01830

Pacific Northwest National Laboratory

Richland, Washington 99352 



\section{Summary}

Computational fluid dynamics (CFD) models were developed to support the siting and design of a behavioral guidance system (BGS) structure in The Dalles Dam (TDA) forebay on the Columbia River. The work was conducted by Pacific Northwest National Laboratory for the U.S. Army Corps of Engineers, Portland District (CENWP). The CFD results were an invaluable tool for the analysis, both from a Regional and Agency perspective (for the fish passage evaluation) and a CENWP perspective (supporting the BGS design and location).

The new CFD model (TDA forebay model) included the latest bathymetry (surveyed in 1999) and a detailed representation of the engineered structures (spillway, powerhouse main, fish, and service units). The TDA forebay model was designed and developed in a way that future studies could easily modify or, to a large extent, reuse large portions of the existing mesh. This study resulted in these key findings:

- The TDA forebay model matched well with field-measured velocity data.

- The TDA forebay model matched observations made at the 1:80 general physical model of the TDA forebay.

- During the course of this study, the methodology typically used by CENWP to contour topographic data was shown to be inaccurate when applied to widely-spaced transect data. Contouring methodologies need to be revisited - especially before such things as modifying the bathymetry in the 1:80 general physical model are undertaken.

Future alignments can be evaluated with the model staying largely intact. The next round of analysis will need to address fish passage demands and navigation concerns. CFD models can be used to identify the most promising locations and to provide quantified metrics for biological, hydraulic, and navigation criteria. The most promising locations should then be further evaluated in the 1:80 general physical model. 



\section{Acknowledgments}

Financial support was provided by U.S. Army Corps of Engineers Portland District. This work was funded under the Columbia River Fish Mitigation (CRFM) Program and specifically The Dalles Juvenile Fish Passage Program. 



\section{Abbreviations and Acronyms}

$\begin{array}{ll}\text { ADCP } & \text { acoustic Doppler current profiler } \\ \text { BGS } & \text { Behavior Guidance System } \\ \text { CAD } & \text { Computer-aided design } \\ \text { CENWP } & \text { U.S.Army Corps of Engineers, Portland District } \\ \text { CFD } & \text { computational fluid dynamics } \\ \text { ERDC } & \text { Engineer Research and Development Center } \\ \text { kcfs } & \text { thousand cubic feet per second } \\ \text { PNNL } & \text { Pacific Northwest National Laboratory } \\ \text { STL } & \text { stereolithography } \\ \text { TDA } & \text { The Dalles Dam } \\ \text { USACE } & \text { U.S. Army Corps of Engineers } \\ \text { USGS } & \text { U.S. Geological Survey }\end{array}$





\section{Contents}

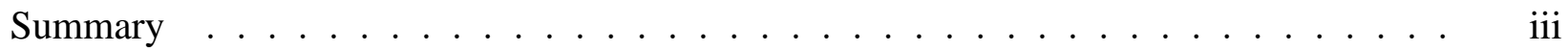

Acknowledgments ......................... . . . . . .

Abbreviations and Acronyms . . . . . . . . . . . . . . vii

1.0 Introduction $\ldots \ldots \ldots \ldots \ldots \ldots \ldots$

2.0 Methods . . . . . . . . . . . . . . . . . . . . . . . . . 2.1

2.1 River Bathymetry and the Geometry of Engineered Structures . . . . . . . . . . 2.1

2.2 Bathymetry Assessment . . . . . . . . . . . . . . . . . 2.1

2.3 Computational Mesh . . . . . . . . . . . . . . . . . . . 2.1

2.3 .1 Forebay Mesh $\ldots \ldots \ldots \ldots \ldots . \ldots \ldots . \ldots \ldots$

$2.3 .2 \quad$ Engineered Structures Meshes . . . . . . . . . . . . . . . . . . . . . 2.4

2.4 Validation of STAR-CD models $\ldots \ldots \ldots$

2.5 Structural and Operational Scenarios . . . . . . . . . . . . . . . . . . . 2.4

2.5 .1 Preliminary Behavioral Guidance System Options . . . . . . . . . . . 2.5

2.5 .2 Options 1 to $5 \ldots \ldots \ldots \ldots \ldots \ldots$

2.5 .3 Option 14. . . . . . . . . . . . . . . . . . 2.8

2.5 .4 Additional Option 14 Simulations $\ldots \ldots \ldots \ldots$

3.0 Results and Discussion . . . . . . . . . . . . . . . . . . . . . . 3.1

3.1 Comparison of Bathymetry Data $\ldots \ldots \ldots \ldots \ldots . \ldots \ldots$

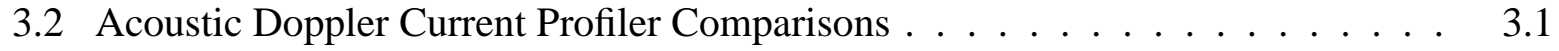

3.3 Preliminary Options $\ldots \ldots \ldots \ldots . \ldots \ldots$

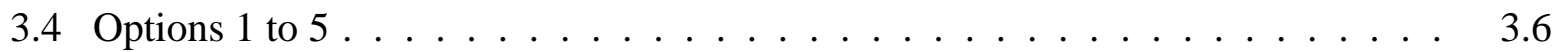

3.4 .1 Evaluation Metrics $\ldots \ldots \ldots \ldots$ 
$3.4 .2 \quad$ Simulation Results . . . . . . . . . . . . . . . . . . . . . . . . 3.10

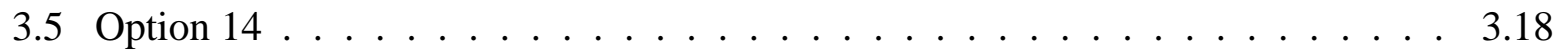

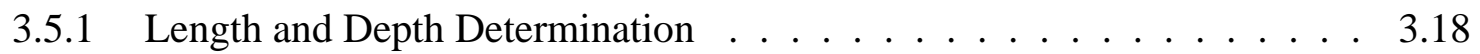

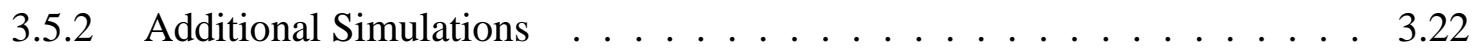

$\begin{array}{lc}3.5 .3 & \text { Simulations to Investigate Navigation Issues }\end{array} \ldots \ldots \ldots \ldots \ldots$

4.0 Conclusions and Recommendations $\ldots \ldots \ldots \ldots$

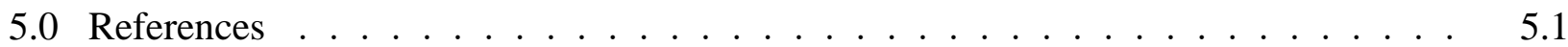

Appendix A - Preliminary Results $\ldots \ldots \ldots \ldots \ldots$ A.1

Appendix B - BGS Figures for Options 1 to $5 \ldots \ldots \ldots$ B.1

Appendix C - Option 14 Results . . . . . . . . . . . . . . . . . . . C.1

Appendix D - Option 14 Navigation Runs and Miscellaneous Runs $\quad \ldots \ldots \ldots$ 


\section{Figures}

$1.1 \quad$ Location of The Dalles Project $\ldots \ldots \ldots \ldots \ldots \ldots$

$2.1 \quad$ Extent of the long (top) and short (bottom) CFD models $\ldots \ldots \ldots \ldots$

2.2 Computational mesh for the preliminary options $\ldots \ldots \ldots \ldots \ldots$

$2.3 \quad$ Proposed locations for BGS placement (Options 1 to 4$) \ldots \ldots \ldots \ldots$

$2.4 \quad$ Location of the Option 14 BGS placement $\ldots \ldots \ldots \ldots \ldots$

$3.1 \quad$ Comparison of bathymetry point data for the physical model and surveyed topography for The Dalles forebay $\ldots \ldots \ldots \ldots \ldots . \ldots \ldots$

3.2 Comparison of ADCP measurements (black) to results from the numerical model (blue) and the numerical model with an added upstream section (red) for April $6,2003 \quad \ldots \ldots \ldots \ldots \ldots \ldots . \ldots \ldots$

3.3 Comparison of ADCP measurements and numerical model results

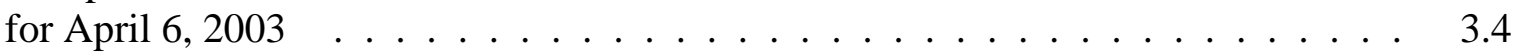

3.4 Comparison of velocity magnitudes for the ADCP measurements and numerical model results for April 6,2003$] \ldots \ldots \ldots \ldots \ldots . \ldots \ldots$

$3.5 \quad$ Preliminary clean forebay run for a Total River of $294 \mathrm{kcfs}, 42 \%$ spill $\ldots \ldots \ldots \ldots \ldots$

3.6 Preliminary run for a 45-degree BGS for a Total River of $294 \mathrm{kcfs}$,

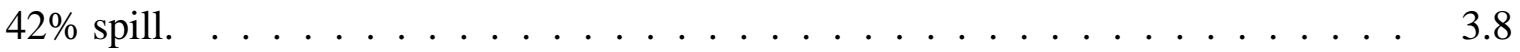

3.7 Preliminary run for a 30-degree BGS for a Total River of $294 \mathrm{kcfs}$,

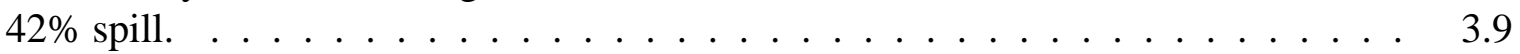

$3.8 \quad$ Helical recirculation along the backside of the BGS was a consistent

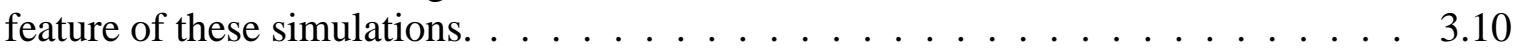

3.9 Particle tracks for Total River $250 \mathrm{kcfs} 40 \%$ spill, standard power-

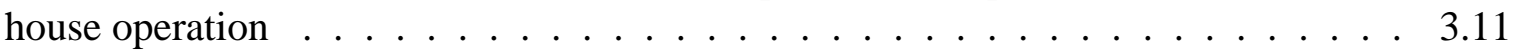

3.10 Comparison for Option 3, Total River $250 \mathrm{kcfs} 20 \%$ spill, standard powerhouse loading to the clean forebay $\ldots \ldots \ldots \ldots \ldots \ldots \ldots$

3.11 Option 1 streamlines for Total River $250 \mathrm{kcfs} 20 \%$ spill, standard powerhouse loading at elevation $148 \mathrm{ft}$ (top) and $138 \mathrm{ft}$ (bottom) $\ldots \ldots \ldots \ldots . . .14$ 
3.12 Particle tracking in The Dalles forebay for particles with a strong depth preference and a weak depth preference. . . . . . . . . . . . . 3.16

3.13 Streamlines from BGS ends for a Total River of $250 \mathrm{kcfs}, 20 \%$ spill,

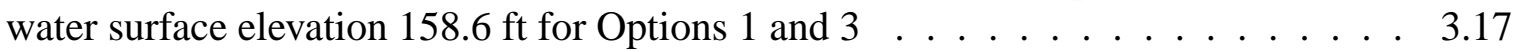

3.14 Streamlines from BGS ends for a Total River of $200 \mathrm{kcfs}, 30 \%$ spill . . . . . . . . . 3.19

3.15 Streamlines from BGS ends for a Total River of $200 \mathrm{kcfs}, 30 \%$ spill . . . . . . . . . 3.20

3.16 Sensitivity to seed location for streamlines from the end of a 1600-

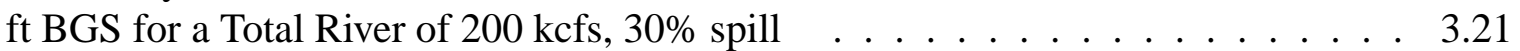

3.17 Simulation results for a 1800 -ft BGS for a Total River of $680 \mathrm{kcfs}$

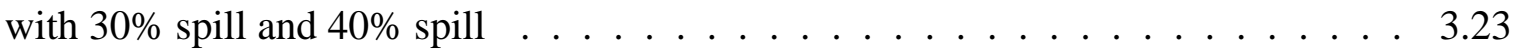

3.18 Simulation results for a BGS slightly angled at the upstream end for a Total River of $200 \mathrm{kcfs}$ with $30 \%$ spill, at elevation $150 \mathrm{ft}$. . . . . . . . . . . 3.24

3.19 Simulation results for a BGS slightly angled at the upstream end for a Total River of $400 \mathrm{kcfs}$ with $30 \%$ spill and $680 \mathrm{kcfs}$ with $62 \%$ spill

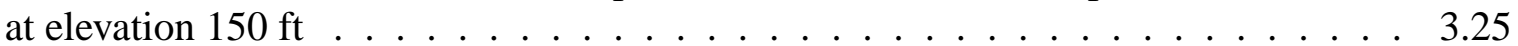

3.20 Simulation results for a 1600-ft BGS with 2-ft gaps every $100 \mathrm{ft}$ for a Total River of $150 \mathrm{kcfs}$ with $30 \%$ spill and a Total River of $200 \mathrm{kcfs}$

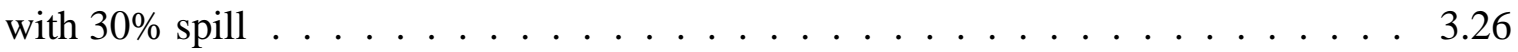

3.21 Simulation results for a 1600-ft BGS with 2-ft gaps every $100 \mathrm{ft}$ for a Total River of $250 \mathrm{kcfs}$ with $30 \%$ spill and a Total River of $300 \mathrm{kcfs}$

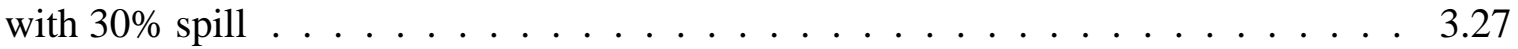

3.22 Simulation results for a Total River of $400 \mathrm{kcfs}$ with $35 \%$ spill for a 1000-ft length and 1100-ft length $\ldots \ldots \ldots \ldots . \ldots \ldots . \ldots \ldots$ 


\section{Tables}

$2.1 \quad$ Document sources for bathymetry data $\ldots \ldots \ldots \ldots \ldots$

$2.2 \quad$ Document sources for TDA structures $\ldots \ldots \ldots \ldots \ldots \ldots$

2.3 Operational scenarios for the CFD simulations of the clean forebay scenario and Options 1 to $5 \ldots \ldots \ldots \ldots$

$2.4 \quad$ Lengths and depths of Option 14 Scenarios . . . . . . . . . . . . . . . . . . . . 2.10

2.5 Option 14 miscellaneous scenarios . . . . . . . . . . . . . . . . 2.10

$2.6 \quad$ Option 14 Navigation evaluation runs $\ldots \ldots \ldots \ldots \ldots$. . . . . . . . . . . 2.11

3.1 Streamline fate from the end of the BGS . . . . . . . . . . . . . . . 3.15 



\subsection{Introduction}

The Dalles Dam (TDA) was constructed during 1952-1957 at river mile 191.5 (Figure 1.1) on the Columbia River. When TDA was constructed, passage facilities for downstream migrant juvenile salmonids were not included. Presently, the only means to pass downstream migrant salmonids at The Dalles Dam through non-turbine routes are spillway and sluiceway operations. Using these routes, fish passage efficiency (FPE) - the proportion of fish passing the dam through non-turbine routes - is about $80-90 \%$. Survival estimates of $92-96 \%$ for spill and $81-86 \%$ for turbine passage are among the lowest in the Columbia River Basin (Ploskey et al.|2001). Thus, there is a definite need to improve passage conditions for juvenile salmon at The Dalles Dam.

In the past 10 years, substantial efforts have been made to enhance spill and sluice passage and to reduce turbine entrainment of downstream migrating salmonids. At the turbine intakes, preliminary work toward development of a turbine intake screen bypass system has been accomplished and is being held in stand-by mode pending results of other efforts. Recently, emphasis was placed on evaluating steel plates that occluded the upper half of the intakes at Main Units 1 to 5. The available data, however, indicate that the occlusion plates did not reduce turbine entrainment rates as intended (Johnson et al. 2003). Sluiceway operations were optimized during evaluations in 2004 and 2005, producing increases (less than 7\%) in sluiceway passage efficiency relative to the powerhouse (Johnson et al. (2005a) and Johnson et al. (2005b)). Therefore, new measures to protect juvenile salmon at TDA need to be developed.

A Behavioral Guidance System (BGS) has been proposed for the forebay of the TDA powerhouse. The BGS is intended to intercept juvenile salmon and guide them to a location that enhances the probability of the salmon passing the project via the spillway rather than through the turbines. The study reported herein supported the siting, configuration, and engineering design of the BGS. Pacific Northwest National Laboratory (PNNL) used computational fluid dynamics (CFD) simulations of the hydraulic conditions in The Dalles forebay for a suite of flow conditions for multiple proposed BGS locations. This study is part of the site selection in the Feasibility Phase of the U.S. Army Corps of Engineers' (USACE) design process.

The primary objective of this study was to create a new numerical model for The Dalles Project forebay that includes the up-to-date bathymetry, extended further upstream, and had a more accurate representation of the powerhouse and spillway structures than previous numerical models for this location. The current need for the numerical model is to support the siting of a BGS structure in The Dalles forebay, but the numerical model was configured in such a way that it can be reused for other analyses in the future. 

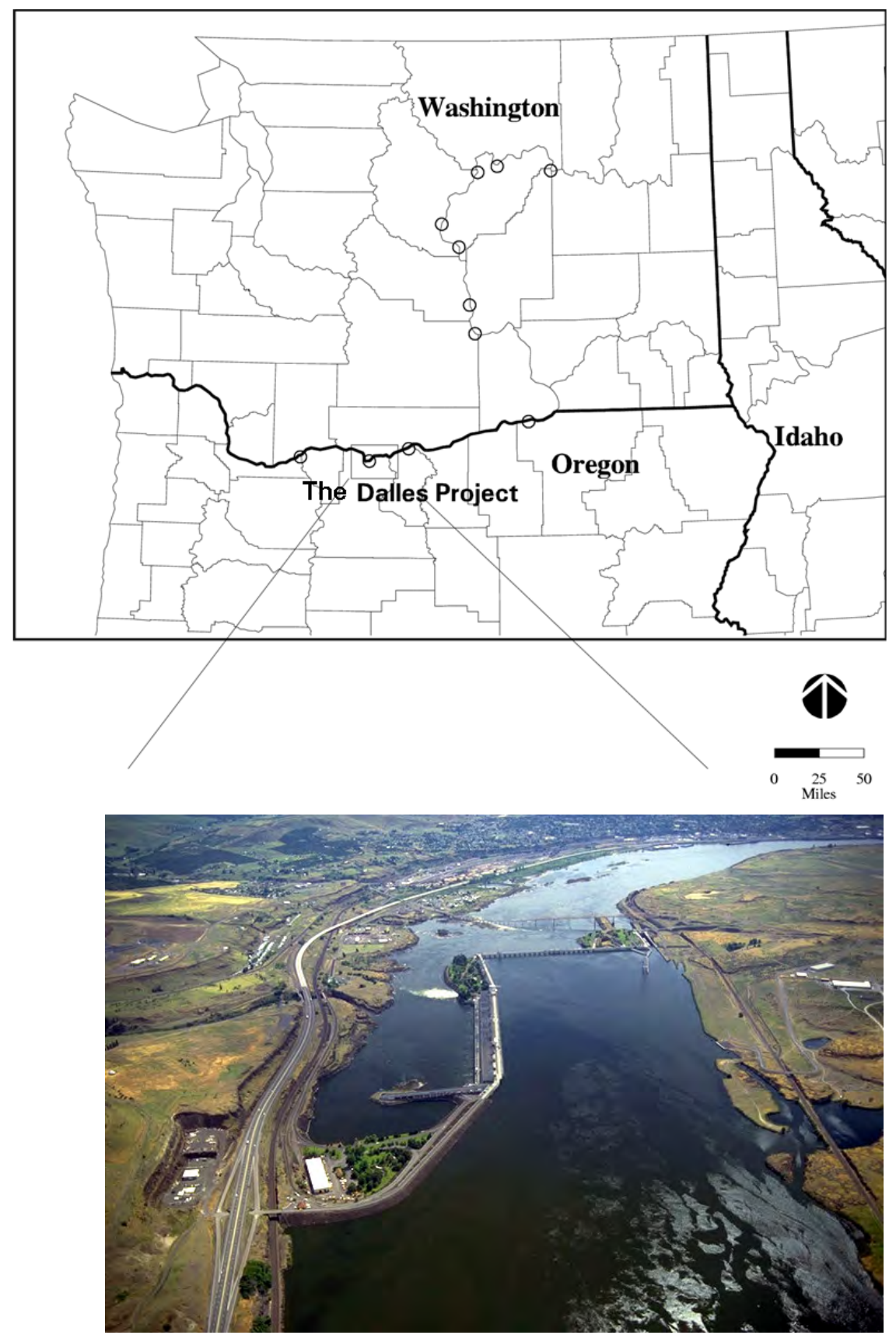

Figure 1.1. Location of The Dalles Project. Looking downstream, the powerhouse is on river left, running parallel to the shoreline; the spillway is across the channel. 


\subsection{Methods}

In this section are the descriptions of the development of the computational mesh, the underlying bathymetry on which the forebay mesh is based, the representation of the engineered structures, and the evolution of the models as needed to fit the changing requirements of this study.

\subsection{River Bathymetry and the Geometry of Engineered Structures}

This work used the bathymetric surface stereolithography (STL) file developed for previous studies at The Dalles Dam (a) The bathymetric surface was developed from the integration of multiple field-surveyed data sets into a single-valued bathymetric surface. The geometry for the engineered structures was updated in the course of other work by PNNL staff for The Dalles sluiceway (Johnson et al. 2005a). Some of those computational meshes were re-used, and other meshes were developed from the updated geometry for the engineered structures as detailed below. In addition, an upstream section of bathymetry was developed based on more widely spaced bathymetry transects measured in 1997 . Contours were added by hand to these data to improve the resultant processed bathymetric surface.

\subsection{Bathymetry Assessment}

One of the first tasks of this project was to assess the differences between the most recent bathymetric data, the data used in the previous CFD model, and the bathymetry that exists at the USACE's Engineer Research and Development Center (ERDC) 1:80 reduced-scale physical model ("the general model") of The Dalles. There were issues that needed to be resolved with the underlying data provided for the general model.

The bathymetry data from the general model were delivered as AutoCAD drawing with contours and point data for elevation. Initially, a continuous surface was made from the contour data. However, it compared very poorly to the newest bathymetric survey, so additional work was done to determine the source of the disparity. When the raw data points from the general model were compared to the surveyed points, the comparison was good. It was determined that the placement of the contour lines did not necessarily represent the bathymetry but rather was an artifact of automatic contouring on widely spaced cross-section lines. Thus, we determined we needed to work from the point data only.

\subsection{Computational Mesh}

One of the prime functions of the new computational grid was to apply it to the BGS studies. The BGS concept is a curtain or wall from the surface to a depth needed to divert surfaceoriented juvenile salmon from the powerhouse to the spillway. Given that objective, it was necessary that there be good vertical resolution in the upper elevations of the water column $(0$ to $12 \mathrm{~m}$ ). It was determined, in consultation with the USACE Portland District, that the upper elevations of the computational grid should be hexadedrals or prisms with the vertical axis as the short axis of the cell. This requirement determined much of the approach used to create the

(a) MC Richmond, PNNL, unpublished data. 
computational mesh for the forebay.

\subsubsection{Forebay Mesh}

The detailed bathymetric surveys of The Dalles forebay (conducted in 1999) were the basis for computational mesh. The surveyed points were used to create a triangular network (TIN) of points. Those points were smoothed in Tecplot (www.tecplot.com) with a relaxation coefficient of 0.5 , and a single-valued continuous surface was created. From this continuous surface, a regularly spaced set of points was sampled and written in an STL format. A complete listing of surveys used in the creation of the STLs is in Table 2.1. Drawings used to created the STLs for the engineered structure are detailed in Table 2.2 .

Table 2.1. Document sources for bathymetry data

\begin{tabular}{|l|l|l|}
\hline \multicolumn{1}{|c|}{ Dataset } & \multicolumn{1}{|c|}{ Source } & \multicolumn{1}{c|}{ Description } \\
\hline PTS-DEM & USGS & $\begin{array}{l}\text { 10-meter digital elevation model used for } \\
\text { topography. }\end{array}$ \\
\hline PTS-MAY2000 & $\begin{array}{l}\text { USACE Arc- } \\
\text { Info cover: } \\
\text { addsurvey }\end{array}$ & $\begin{array}{l}\text { Additional points from the May 24, } \\
\text { 2000, hydrographic survey. }\end{array}$ \\
\hline PTS-99222FORE-TAIL & $\begin{array}{l}\text { USACE file: } \\
\text { 99222Dal- } \\
\text { points.dgn }\end{array}$ & $\begin{array}{l}\text { Detailed bathymetry survey conducted } \\
\text { in September 1999 by Minister-Glaeser } \\
\text { Surveying, Inc covering areas above and } \\
\text { below dam. Some anomalous points } \\
\text { removed. }\end{array}$ \\
\hline PTS-FORE160 PTS-TAIL74 & $\begin{array}{l}\text { USGS } \\
\text { DOQQ }\end{array}$ & $\begin{array}{l}\text { Columbia River shoreline points devel- } \\
\text { oped from digital orthoquad image. }\end{array}$ \\
\hline
\end{tabular}

Table 2.2. Document sources for TDA structures

\begin{tabular}{|l|rl|}
\hline \multicolumn{1}{|c|}{ Structure } & \multicolumn{2}{|c|}{ Document } \\
\hline Spillway & USACE drawings: & DDD-1-4-1/1 \\
& & DDD-1-4-2/1 \\
& & DDD-1-4-4/1 \\
& & DDD-1-4-8-9i \\
\hline Powerhouse & USACE drawings: & DDP-1-0-0/2 \\
& & DDP-1-0-0/7 \\
& & DDP-8-0-0/7 \\
\hline Non-Spill Dam & USACE drawings: & DDD-1-4-3.1/1 \\
\hline
\end{tabular}

Gridgen software (www.pointwise.com) was used to create the computational mesh. First, the STL for the bathymetric surface was imported into Gridgen. It was necessary to extract lines of constant elevation (e.g., shorelines) of a specified elevation to delineate the canyon sections and the lateral spatial extent of the numerical model. However, these iso-elevation lines cannot be 
extracted from the STL surface directly; a multi-step process was required. A set of structured domains was created that encompassed the complete extent of the river and some of the upland area. The domains were then projected onto the STL surface and the Gridgen solver run to improve the mesh quality and its representation of the underlying bathymetry. These structured domains were exported as domains and then imported into Gridgen as a database. Planes of constant elevation (120 ft and $150 \mathrm{ft}$ ) were created and intersected with the structured domains. The resulting intersection lines from the 150-ft elevation were used as shorelines. The 150-ft elevation was chosen to delineate the lateral extent of the river. The final water surface elevation was $158.6 \mathrm{ft}$; using the 150 - $\mathrm{ft}$ elevation for the shoreline eliminates only a very small area but provides an adequate depth for the mesh creation. The forebay elevation at TDA can range from 155 to $160 \mathrm{ft}$, but is typically 158 to $159 \mathrm{ft}$. The $158.6-\mathrm{ft}$ elevation was used throughout this study, as it corresponds to a field-measured validation data set (see Section 2.4 as well as being representative of a typical forebay elevation.

To create hexahedral and prism cells in the upper elevations and resolve the very complex canyon areas, we created the computational mesh for the forebay in multiple parts. In the canyon areas, which are upstream of the powerhouse and BGS location, a tetrahedral mesh was developed for the areas (typically) less than 120-ft elevation. It was necessary to subdivide the surface to be meshed into many unstructured domains to ensure the accurate projection of each domain onto the STL surface. The canyon areas were enclosed with a "lid" with its edge at elevation 120 $\mathrm{ft}$. The interior points of the lid were projected to an elevation of $130 \mathrm{ft}$ to allow successful filling of the volume with tetrahedrals, even in the shallower areas. Unstructured domains were created for the areas between the 120-ft and 150-ft elevation shorelines for the forebay. The upper elevation of the water column (120 elevation and above) was then extruded in STAR-CD to a final water surface elevation of $158.6 \mathrm{ft}$.

The forebay between the most upstream end of the powerhouse and the spillway has less topographic relief than the upstream canyon areas of the river thalweg. There is an excavated edge on the approach to the spillway on the Washington shore side of the spillway that extends from about elevation $100 \mathrm{ft}$ to $136 \mathrm{ft}$. The area between the powerhouse and the excavated slope was represented by extruding five layers from unstructured domains projected onto the bathymetric surface up to an elevation of $120 \mathrm{ft}$. A small triangular wedge was created to represent the wedge between the extruded zone upstream of the spillway and the excavated sloped area. Unstructured domains were used for the sloped edge and top surface. A vertical structured mesh equivalent to that created by the cell extrusion was used for the vertical edge abutting the extruded cells upstream of the spillway. Tetrahedral cells were used to fill in the wedge shaped transitional area. The lower and transitional element faces were integrated into a connect volume by merging the vertices in STAR-CD. A single-shell surface of unstructured elements representing the bathymetry of the elevation above $120 \mathrm{ft}$ and the top of the extruded areas below 120 $\mathrm{ft}$ was then used to extrude the rest of the forebay in nine layers to a water surface elevation of $158.6 \mathrm{ft}$.

To most efficiently include overlapping proposed BGS locations, the numerical model was created with a section that was easily replaced for each BGS option. Consequently, most of the computational mesh was unchanged between different BGS options. The end points of the BGS alignments were provided by the USACE, Portland District. 


\subsubsection{Engineered Structures Meshes}

The TDA Powerhouse is composed of different types of turbine units. The main, service, and fish unit computational meshes were developed from STLs created in a CAD from the paper drawings of the units. In addition, a much more detailed version of a main unit, developed for other work (Johnson et al.2005a), was used to represent the most upstream Main units (Units 17-22) with greater accuracy. The powerhouse units were meshed in a rectangular coordinate system, and then the meshes rotated, replicated, and translated to appropriate locations for the full forebay model. These units were integrated into a continuous computational mesh. The detailed powerhouse units are composed of approximately 189,000 cells; however, the gatewell cells and the cells downstream of the gatewell could be eliminated from the model, leaving about 128,000 cells per unit. The determination that the cells downstream of the gatewell could be removed was made from looking at previous simulation results that used this version of the turbine intake. These results showed that the velocities were nearly uniform across the line of truncation.

\subsection{Validation of STAR-CD models}

STAR-CD (ADAPCO 2004) has been applied to the forebays of both Bonneville (e.g., Rakowski et al. (2000)) and The Dalles (e.g., Johnson et al. (2005a), ENSR (2001)) dams for several studies for CENWP. Experience to date is that no calibration is necessary if the model geometry is correct and a high-Reynold's number two-equation turbulence model is used. Typically, only sparse validation data are available. Measurements of velocities in The Dalles forebay, measured with an acoustic Doppler current profiler (ADCP), were collected on April 6, 2003 (Mannheim and Sweeney 2003). These ADCP data were provided to PNNL in an Excel spreadsheet with a timeaveraged velocity and standard deviation for each location and depth. Validation simulations were made for

- the new TDA mesh including the preliminary options

- the new mesh with an added upstream section.

The project operations were those for the simulations for April 6, 2003, and were taken from Mannheim and Sweeney (2003). The numerical model, for validation runs and all other cases, was run using a k-epsilon high-Reynolds number turbulence closure. The flow through the model domain was specified using a velocity at each outflow boundary. The specified velocity was determined by dividing the desired outflow by the boundary area. The upstream boundary was set to a pressure boundary.

\subsection{Structural and Operational Scenarios}

There were several phases to CFD modeling for the BGS site selection process:

1. Create a CFD model for the preliminary proposed BGS locations.

2. Create CFD models for the BGS locations developed during the first ERDC physical model 
trip.

3. Create CFD models for the final alignment chosen during the second ERDC physical model trip.

4. Perform simulations as requested.

5. Perform simulations to support navigation studies.

The CFD model results were used in concert with trips to the ERDC to examine the 1:80 scale general physical model of TDA. All CFD models, simulation results, and evaluation metrics extracted from the results were provided to CENWP in electronic format.

\subsubsection{Preliminary Behavioral Guidance System Options}

The BGS in the proposed preliminary locations (provided by CENWP) were included in the initial numerical models. Prior to the first trip to ERDC (February 2005), the flow fields for these preliminary alignments were simulated, and the results studied during the ERDC trip. The BGS structures in the model were represented as baffles (thin walls) in the model, extending from a point at the east end of the powerhouse (Easting 1841346.9, Northing 712758.1 in Oregon North State Plane feet) across the forebay at angles of 45 and 30 degrees from the face of the powerhouse. As the mesh below the BGS location was somewhat coarse relative to the near-surface cells, the cells below the BGS and up and downstream from the BGS were refined to provide more accurate flow solutions in this area with a flow constriction and subsequent expansion.

Prior to simulating a BGS in the numerical model, we assessed the impact of moving the upstream boundary location. The upstream boundary location was further upstream than in previous models, but the area of interest for this modeling effort was also further upstream and included Big Eddy (Figure 2.1). It was determined that the planned upstream location was sufficient and that the great upstream extent was not needed. This was done by comparing the flow solutions for the ADCP validation conditions.

Both the 30-degree and 45-degree BGS options were simulated for a powerhouse flow of 167 $\mathrm{kcfs}$, spillway flow of $124 \mathrm{kcfs}$, and sluiceway flow of $3 \mathrm{kcfs}$. The objective of this part of the study was to assess the potential impact to the flow field of the BGS for multiple locations and multiple lengths.

Both of these options had a common upstream start location and were either 1700 or $2000 \mathrm{ft}$ in length. The mesh was created by creating unstructured domains in the removable BGS area (Figure 2.2). These triangles were extruded as prisms up to an elevation of $120 \mathrm{ft}$. The $120 \mathrm{ft}$ elevation surface was extruded to the water surface elevation of $158.6 \mathrm{ft}$. A baffle (a vertical impermeable layer) was added in the appropriate locations for the BGS. Cells below and adjacent to the BGS were refined to improve flow field resolution in the vicinity of the BGS. 


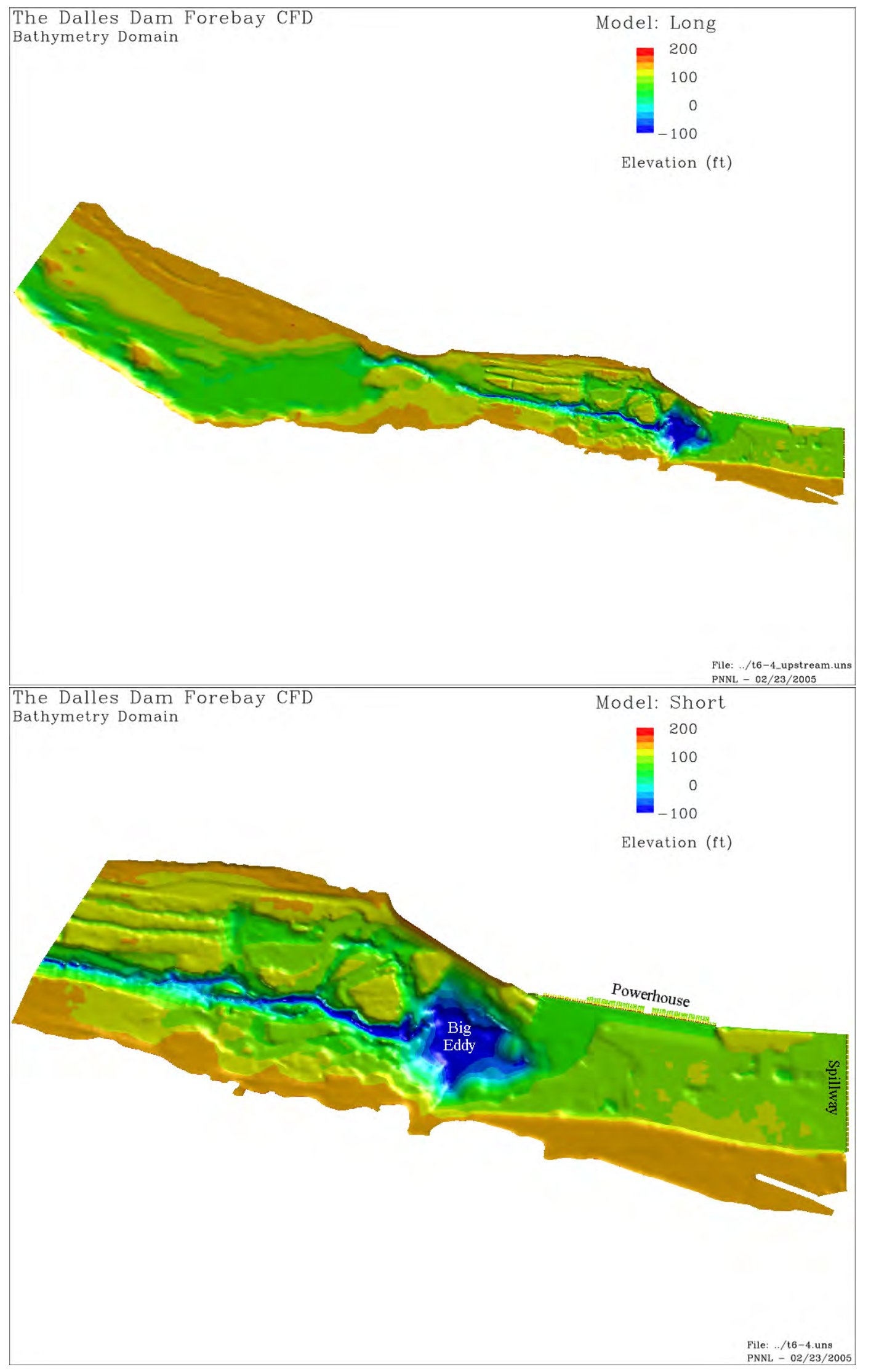

Figure 2.1. Extent of the long (top) and short (bottom) CFD models. Contours show the elevation of the river bottom. 


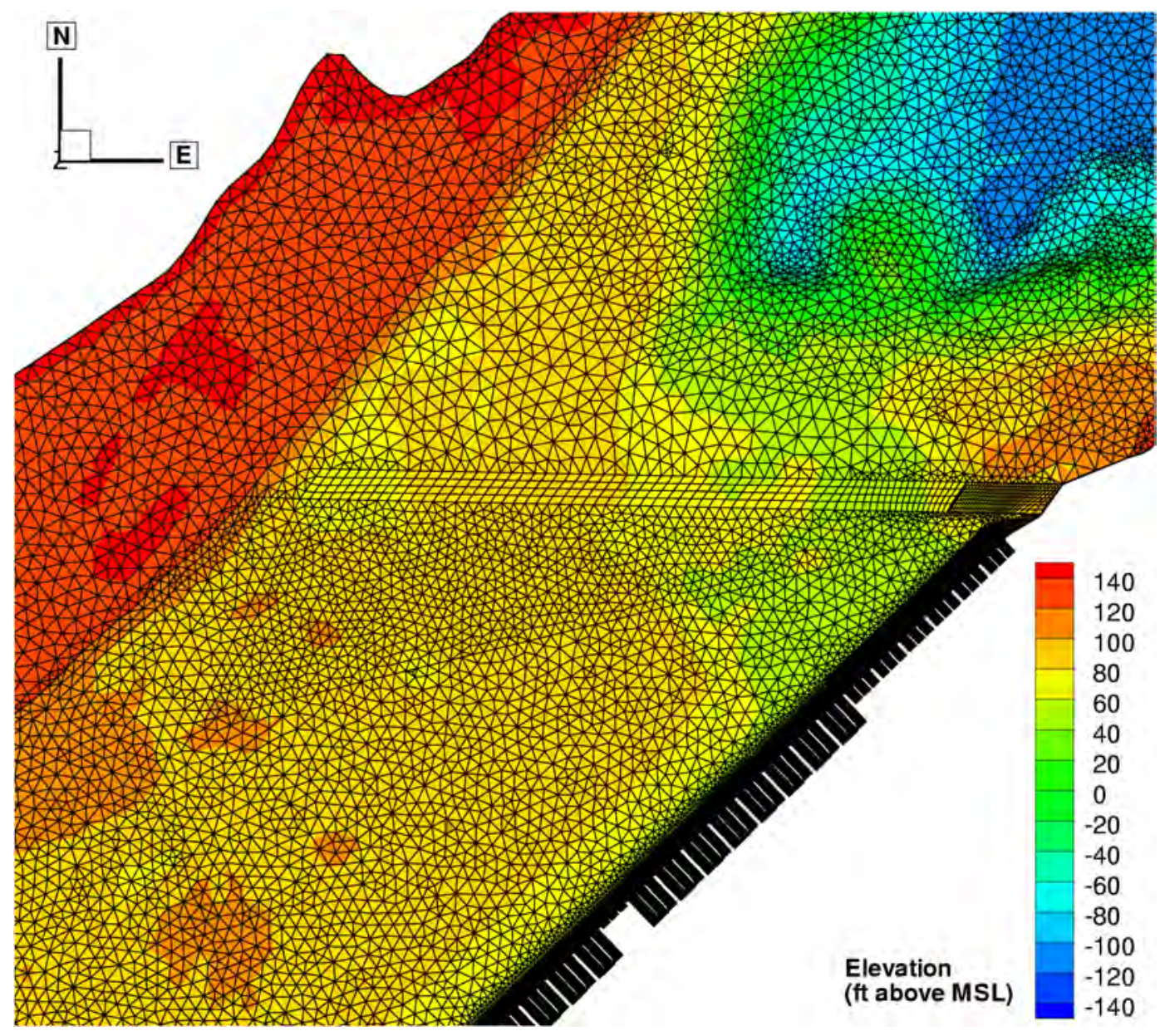

Figure 2.2. Computational mesh for the preliminary options. Contoured data show bottom elevation.

\subsubsection{Options 1 to 5}

While at the ERDC 1:80 general physical model of TDA, CENWP and agency personnel developed four proposed locations for the BGS (Figure 2.3). These locations were simulated in the numerical model and a suite of metrics developed to assess potential impact to downstream migrant juvenile salmonids. Coordinates at the ends of the proposed locations were provided by CENWP, and BGS structures at those locations were incorporated into the numerical model. Option 5 had the same location as Option 3; however, the BGS was shaped (billowed and scalloped) to represent a BGS made of flexible material that would deform both vertically and horizontally when placed in the river. The Option 5 BGS was anchored every $150 \mathrm{ft}$. A suite of operational scenarios was specified by CENWP in coordination with agency personnel (see Table 2.3 .

A separate computational mesh for the BGS area was developed for each of these options. The remainder of the computational mesh was unchanged between options. The triangles in the BGS area were extruded as discussed in Section 2.5.1, and the cells near the BGS were refined. The number of cells in each mesh for each option was about 3 million. The BGS was approx- 
imated as an impermeable vertical layer for Options 1 through 4 and a scalloped and billowed impermeable layer for Option 5.

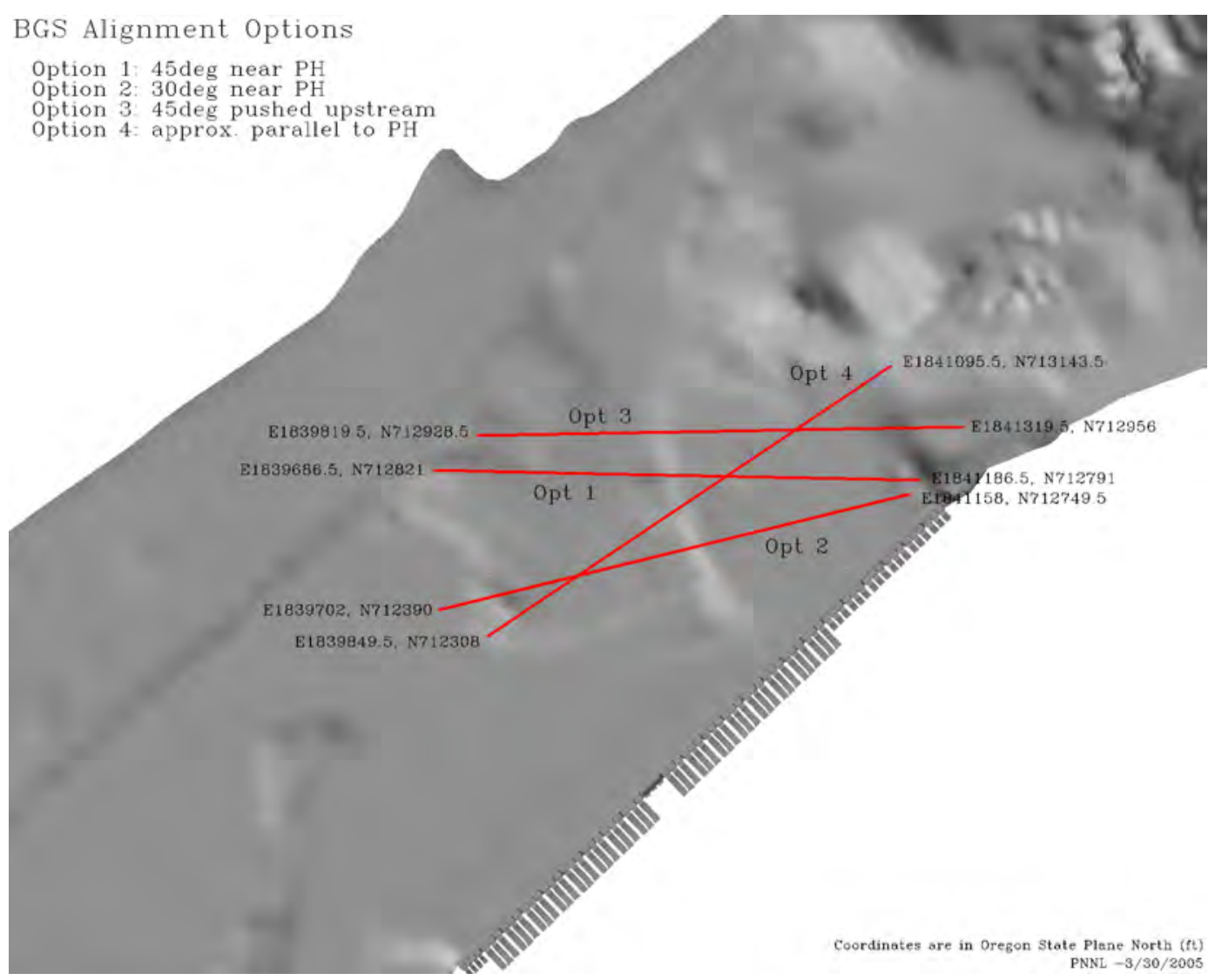

Figure 2.3. Proposed locations for BGS placement (Options 1 to 4)

\subsubsection{Option 14}

During the second trip to ERDC (June 2005), a final location for the proposed BGS was determined by CENWP personnel and agency personnel; see Figure 2.4. This final location is referred to as Option 14. The CFD model was used to determine the final length and, in conjunction with fish distribution and migration pathway data (Cash et al. 2005), the draft of the BGS. To determine the length that would guide fish to the spillway but not put them in the more predator-prone shallow areas near the Washington shore, simulations for $1500 \mathrm{ft}, 1600 \mathrm{ft}, 1700$ $\mathrm{ft}$, and $1800 \mathrm{ft}$ were run (see Table 2.4) for a single total river discharge and spill (200 kcfs with $30 \%$ spill) for 20-, 30-, and 40-ft-depth BGS configurations. In addition, simulations for an $800-\mathrm{ft}$ BGS were run as an indication of performance of an 800-ft prototype test of a BGS. There were approximately 3.4 million cells in this numerical model.

\subsubsection{Additional Option 14 Simulations}

Additional simulations were requested by CENWP (Table 2.5). The CFD simulation results for flood flows were used by USACE to assist in its load calcations required for the design of the 
Table 2.3. Operational scenarios for the CFD simulations of the clean forebay scenario and Options 1 to 5

\begin{tabular}{ccccccccc}
\hline $\begin{array}{c}\text { Total River } \\
(\mathrm{kcfs})\end{array}$ & Spill \% & PH Op & Clean & Opt 1 & Opt 2 & Opt 3 & Opt 4 & Opt 5 \\
\hline 150 & 40 & 1 & $\mathrm{x}$ & $\mathrm{x}$ & $\mathrm{x}$ & $\mathrm{x}$ & $\mathrm{x}$ & \\
150 & 20 & 1 & $\mathrm{x}$ & $\mathrm{x}$ & $\mathrm{x}$ & $\mathrm{x}$ & $\mathrm{x}$ & $\mathrm{x}$ \\
200 & 40 & 1 & $\mathrm{x}$ & $\mathrm{x}$ & $\mathrm{x}$ & $\mathrm{x}$ & $\mathrm{x}$ & \\
200 & 20 & 1 & $\mathrm{x}$ & $\mathrm{x}$ & $\mathrm{x}$ & $\mathrm{x}$ & $\mathrm{x}$ & $\mathrm{x}$ \\
250 & 40 & 1 & $\mathrm{x}$ & $\mathrm{x}$ & $\mathrm{x}$ & $\mathrm{x}$ & $\mathrm{x}$ & $\mathrm{x}$ \\
250 & 40 & 2 & $\mathrm{x}$ & & & $\mathrm{x}$ & & \\
250 & 30 & 1 & $\mathrm{x}$ & $\mathrm{x}$ & $\mathrm{x}$ & $\mathrm{x}$ & $\mathrm{x}$ & \\
250 & 30 & 2 & $\mathrm{x}$ & $\mathrm{x}$ & & & & \\
250 & 20 & 1 & $\mathrm{x}$ & $\mathrm{x}$ & $\mathrm{x}$ & $\mathrm{x}$ & $\mathrm{x}$ & $\mathrm{x}$ \\
250 & 20 & 2 & $\mathrm{x}$ & $\mathrm{x}$ & $\mathrm{x}$ & $\mathrm{x}$ & & $\mathrm{x}$ \\
300 & 40 & 1 & $\mathrm{x}$ & & & & & \\
300 & 20 & 1 & $\mathrm{x}$ & $\mathrm{x}$ & $\mathrm{x}$ & $\mathrm{x}$ & $\mathrm{x}$ & $\mathrm{x}$ \\
350 & 40 & 1 & $\mathrm{x}$ & $\mathrm{x}$ & $\mathrm{x}$ & $\mathrm{x}$ & $\mathrm{x}$ & \\
350 & 20 & 1 & $\mathrm{x}$ & $\mathrm{x}$ & $\mathrm{x}$ & $\mathrm{x}$ & $\mathrm{x}$ & $\mathrm{x}$ \\
400 & 40 & 1 & $\mathrm{x}$ & & & & & \\
\hline
\end{tabular}

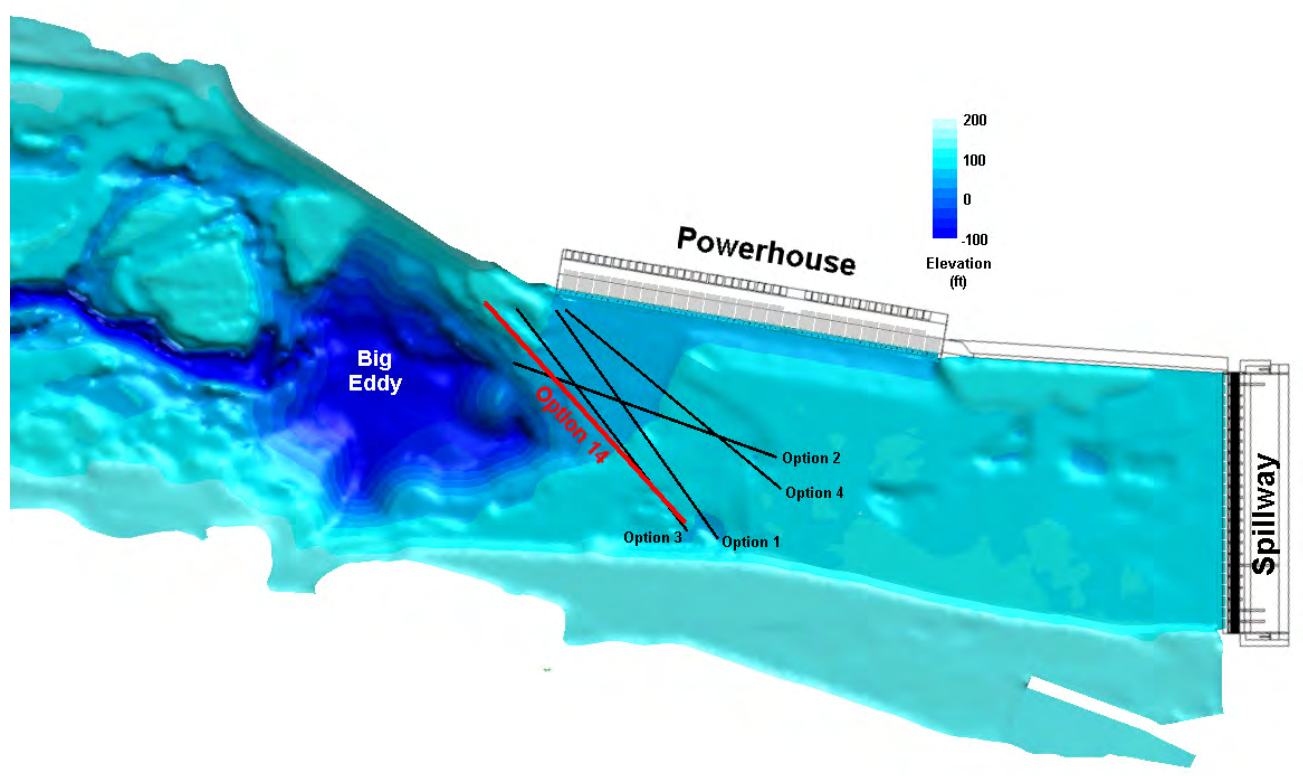

Figure 2.4. Location of the Option 14 BGS placement 
Table 2.4. Lengths and depths of Option 14 Scenarios. All simulations had a Total River of $200 \mathrm{kcfs}$ with $30 \%$ spill.

\begin{tabular}{cccc}
\hline Length & \multicolumn{3}{c}{ Draft } \\
\hline & $40 \mathrm{ft}$ & $30 \mathrm{ft}$ & $20 \mathrm{ft}$ \\
\hline clean & & & \\
800 & $\mathrm{x}$ & $\mathrm{x}$ & $\mathrm{x}$ \\
1500 & $\mathrm{x}$ & $\mathrm{x}$ & $\mathrm{x}$ \\
1600 & $\mathrm{x}$ & $\mathrm{x}$ & $\mathrm{x}$ \\
1700 & $\mathrm{x}$ & $\mathrm{x}$ & $\mathrm{x}$ \\
1800 & $\mathrm{x}$ & $\mathrm{x}$ & $\mathrm{x}$
\end{tabular}

anchoring system. The flood scenarios were for $680 \mathrm{kcfs}$ for the $1800-\mathrm{ft}$ BGS. The spillway had $15.6 \mathrm{kcfs}$ through both Bay 1 and Bay 23, and $30.9 \mathrm{kcfs}$ through each of Bays 2 through 22 . Computational meshes were created and simulations were run for a BGS tilted vertically as if by flood flows for a bottom-anchored system and for a BGS with the upstream $300 \mathrm{ft}$ angled more parallel to the flows. The latter was run for three total river flows (200, 400, and $680 \mathrm{kcfs})$ to determine if an alternative design would reduce the loading on the upstream section of the BGS. The computational mesh for the tilted BGS was created and provided to USACE CENWP. This tilted BGS simulations was used by USACE to assess the loads and effects of flood flows on a bottom-anchored BGS.

Table 2.5. Option 14 miscellaneous scenarios

\begin{tabular}{ccc}
\hline Mesh & Draft & \\
\hline & $40 \mathrm{ft}$ & $30 \mathrm{ft}$ \\
\hline flood & $\mathrm{x}$ & $\mathrm{x}$ \\
tilted & $\mathrm{x}$ & \\
slightly turned & $\mathrm{x}$ &
\end{tabular}

During a December 2005 trip to the ERDC physical model, it was found that the Option 14 BGS final length $(1600 \mathrm{ft})$ and draft $(40 \mathrm{ft})$ had a negative impact on navigation. The USACE requested additional CFD runs of a BGS in the Option 14 location but for shorter lengths (800$1200 \mathrm{ft}$ ) in 100-ft increments. In addition, CFD runs of a 1600-ft BGS with 2-ft gaps every 100 $\mathrm{ft}$ at lower total river flows were requested. The operational conditions for the navigation runs are detailed in Table 2.6 
Table 2.6. Option 14 Navigation evaluation runs. The 1600-ft BGS runs had 2-ft gaps inserted every $100 \mathrm{ft}$ along the BGS.

\begin{tabular}{cccccc}
\hline Case & $\begin{array}{c}\text { Total } \\
\text { River }\end{array}$ & $\begin{array}{c}\text { Spill } \\
\text { Percentage }\end{array}$ & $\begin{array}{c}\text { Spill } \\
\text { Flow (kcfs) }\end{array}$ & $\begin{array}{c}\text { BGS } \\
\text { Length }\end{array}$ & Draft \\
\hline 1 & 300 & 120 & 40 & Clean & NA \\
2 & 400 & 160 & 40 & Clean & NA \\
3 & 500 & 240 & 48 & Clean & NA \\
4 & 300 & 90 & 30 & 800 & 40 \\
5 & 300 & 120 & 40 & 800 & 40 \\
6 & 400 & 140 & 35 & 800 & 40 \\
7 & 400 & 160 & 40 & 800 & 40 \\
8 & 500 & 240 & 48 & 800 & 40 \\
9 & 400 & 140 & 35 & 900 & 40 \\
10 & 500 & 240 & 48 & 900 & 40 \\
11 & 400 & 140 & 35 & 1000 & 40 \\
12 & 500 & 240 & 48 & 1000 & 40 \\
13 & 400 & 140 & 35 & 1100 & 40 \\
14 & 500 & 240 & 48 & 1100 & 40 \\
15 & 400 & 140 & 35 & 1200 & 40 \\
16 & 500 & 240 & 48 & 1200 & 40 \\
17 & 150 & 45 & 30 & 1600 & 40 \\
18 & 200 & 60 & 30 & 1600 & 40 \\
19 & 250 & 75 & 30 & 1600 & 40 \\
20 & 300 & 90 & 30 & 1600 & 40
\end{tabular}





\subsection{Results and Discussion}

This work was done in many phases to accomodate the evolving needs of the siting study. Discussions of the results are included in each section as they help to explain the decisions and later phases of the siting study.

\subsection{Comparison of Bathymetry Data}

The bathymetry of The Dalles forebay is used in several different hydraulic analysis tools. When comparing results from these different tools, or putting results into context, it is important to understand how results may differ or have limitations because the underlying bathymetric data are different.

PNNL was tasked to compare the prototype bathymetry from the most recent forebay survey to the bathymetry in the ERDC 1:80 general model. To evaluate the actual differences between the physical model and the prototype bathymetry, we worked with only the point data from the survey transects. Figure 3.1 shows the point data from the physical model transects and the field-surveyed points. Figure 3.1 shows that although there is an area between Big Eddy and the Washington shore that has large differences (about $150 \mathrm{ft}$ ), the elevations are very similar for the rest of the model extent. The large bathymetric difference near Big Eddy results from the lateral extent of the deep area that was built into the general model so that it extends further toward the Washington shore than it does in the prototype.

\subsection{Acoustic Doppler Current Profiler Comparisons}

One set of velocity validation data (ADCP) was available for this work. These data were used for validation of simulated velocities using several versions of the computational mesh. Two separate issues were addressed with the validation task. First was the validation of the new computational mesh in The Dalles forebay and sensitivity testing of the results in the area of interest to the location of the upstream boundary. The latter was tested by adding the upstream section, and the results were used to ascertain if the upstream boundary in the numerical model was sufficiently far from the area of interest. In this case, the most upstream ADCP locations happen to coincide with the areas of interest for this study. If the upstream boundary location was affecting the simulated velocities in the areas of interest, the velocities would be different between the two models for the upstream ADCP measurement locations.

Simulations using the new computational mesh compared well to the ADCP measurements of Mannheim and Sweeney (2003) on April 6, 2003. The initial tests of the computational mesh compared the results for the base model and the base model with an extended upstream section. Figure 3.2 shows the most upstream locations of the ADCP measurements. The differences in model results and measured velocities are the most pronounced at these upstream locations. However, because there was very little difference in simulated velocities, it was decided, in consultation with the USACE, that the added upstream section was not necessary and that the shorter upstream extend (as shown in Figure 2.1, bottom) would be used for all subsequent simulations. 


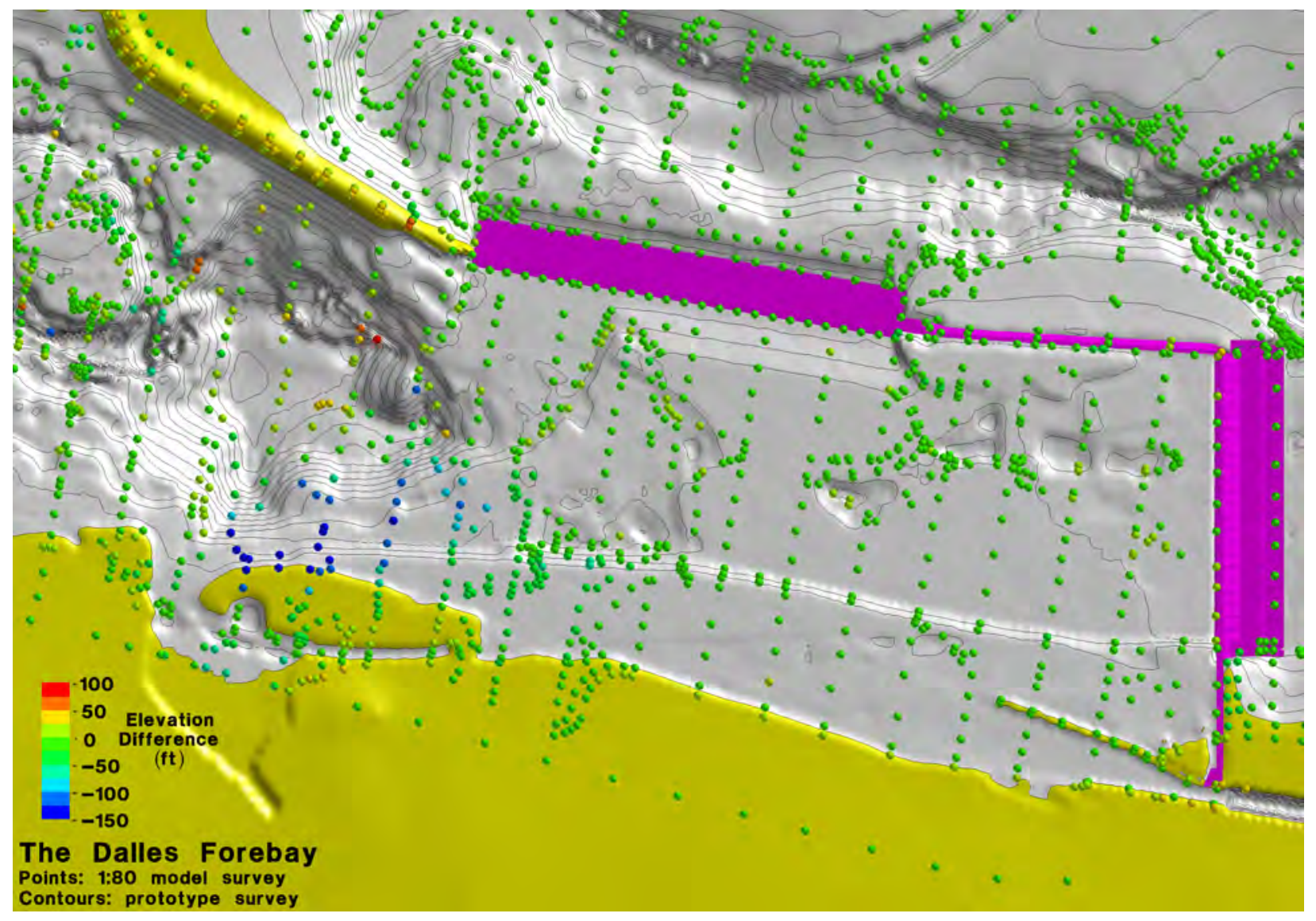

Figure 3.1. Comparison of bathymetry point data for the physical model and surveyed topography for The Dalles forebay

Figure 3.3 shows the measured and simulated velocity vectors for the other ADCP points in The Dalles forebay. Overall, the comparison was quite good. However, in areas with very low velocities (e.g., Figure 3.3), the comparison was not as good. Figure 3.4 compares the fieldmeasured and simulated velocity magnitude for each point and a 1:1 line. The $\mathrm{R}^{2}$ was 0.79 for 630 points. It should be noted that for these field-measured ADCP points, the average standard deviation in the horizontal plane was about $0.4 \mathrm{ft} / \mathrm{s}$ and was not a function of velocity magnitude; $95 \%$ of the measurements had a standard deviation between 0.25 and $0.55 \mathrm{ft} / \mathrm{s}$. In addition, most of the measurement locations had a standard deviation greater than the measured velocity magnitude. Most simulation results fell well within the standard deviation of the measurements. 


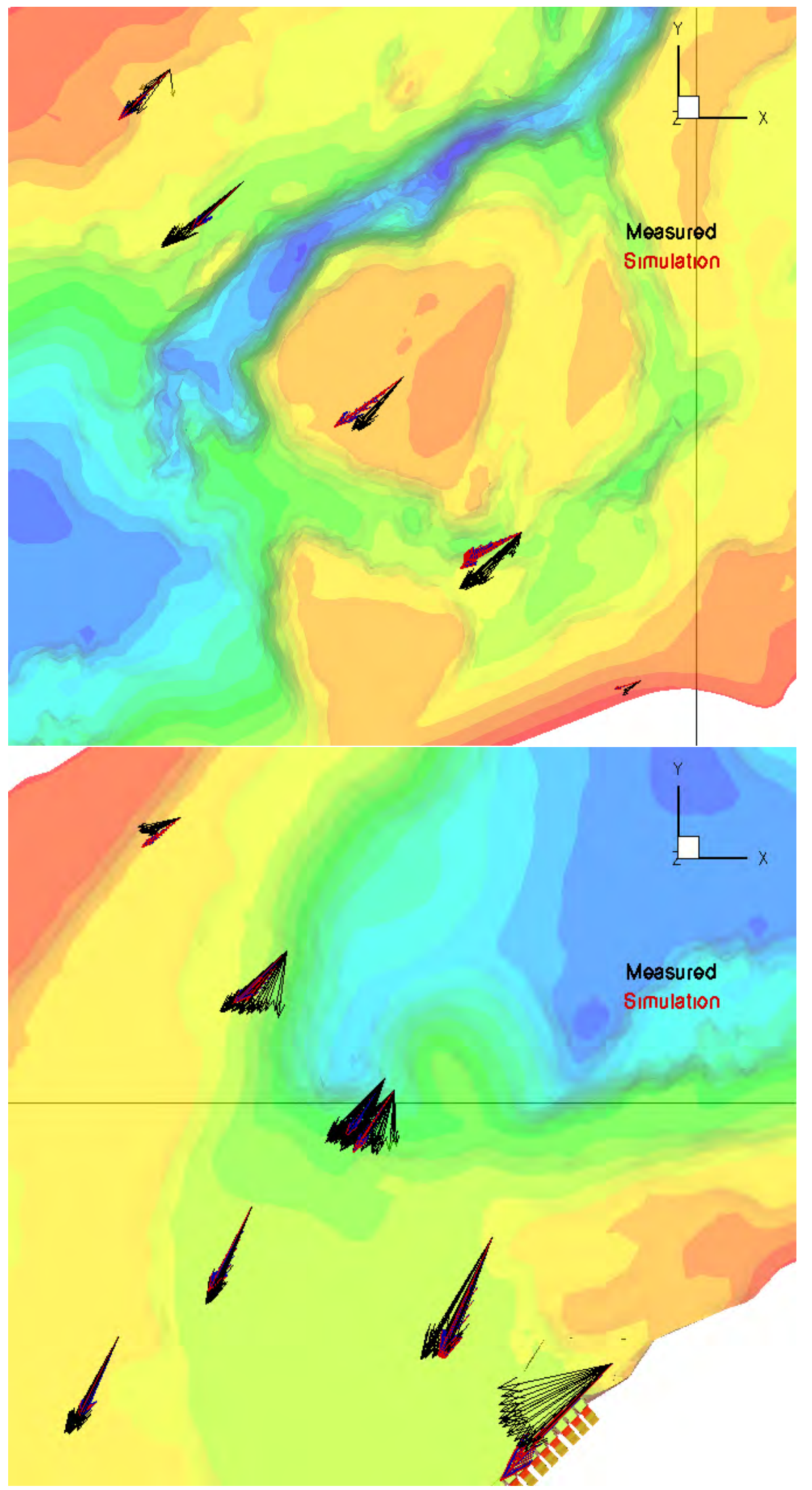

Figure 3.2. Comparison of ADCP measurements (black) to results from the numerical model (blue) and the numerical model with an added upstream section (red) for April 6, 2003 


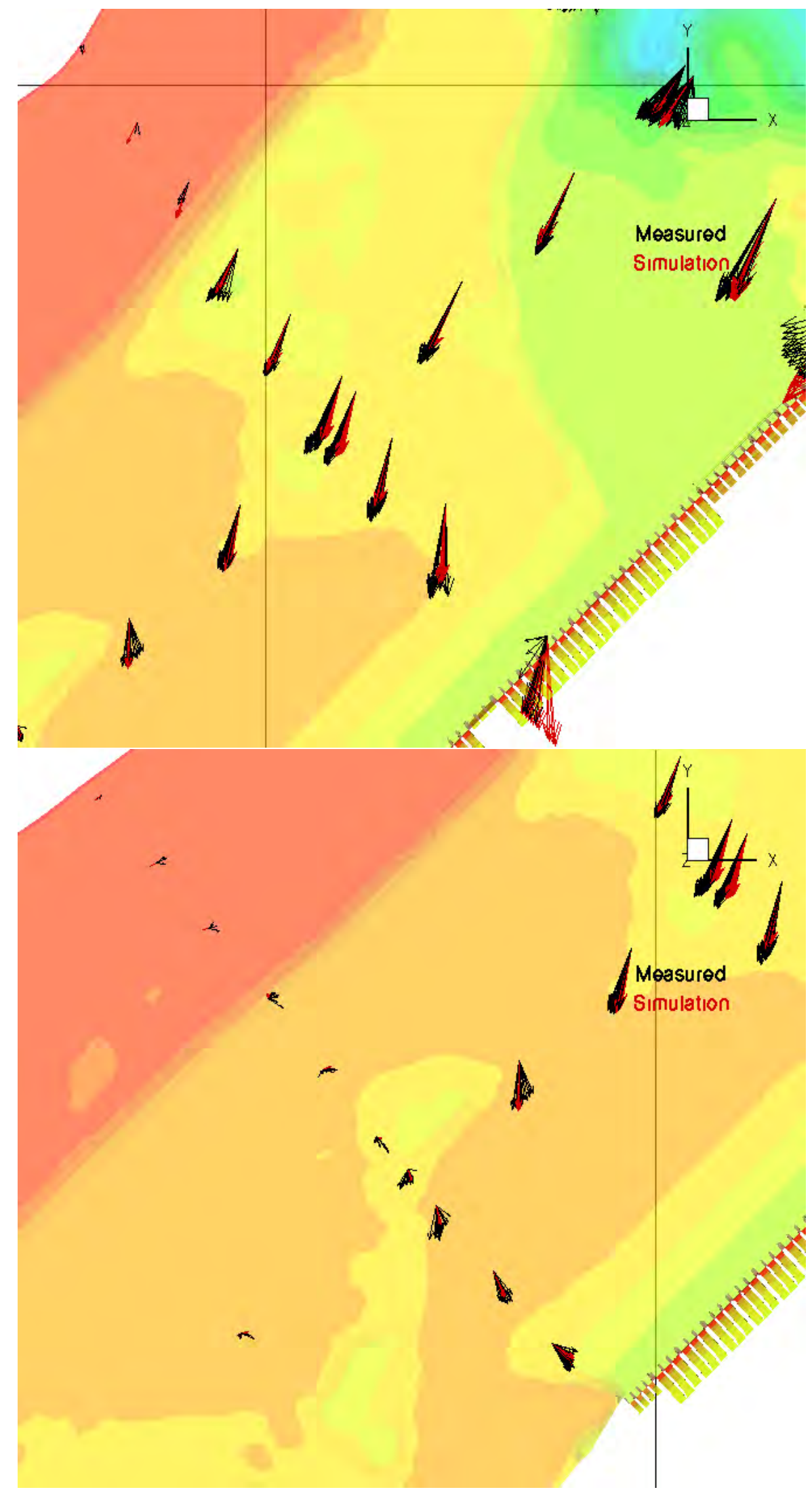

Figure 3.3. Comparison of ADCP measurements and numerical model results for April 6, 2003 


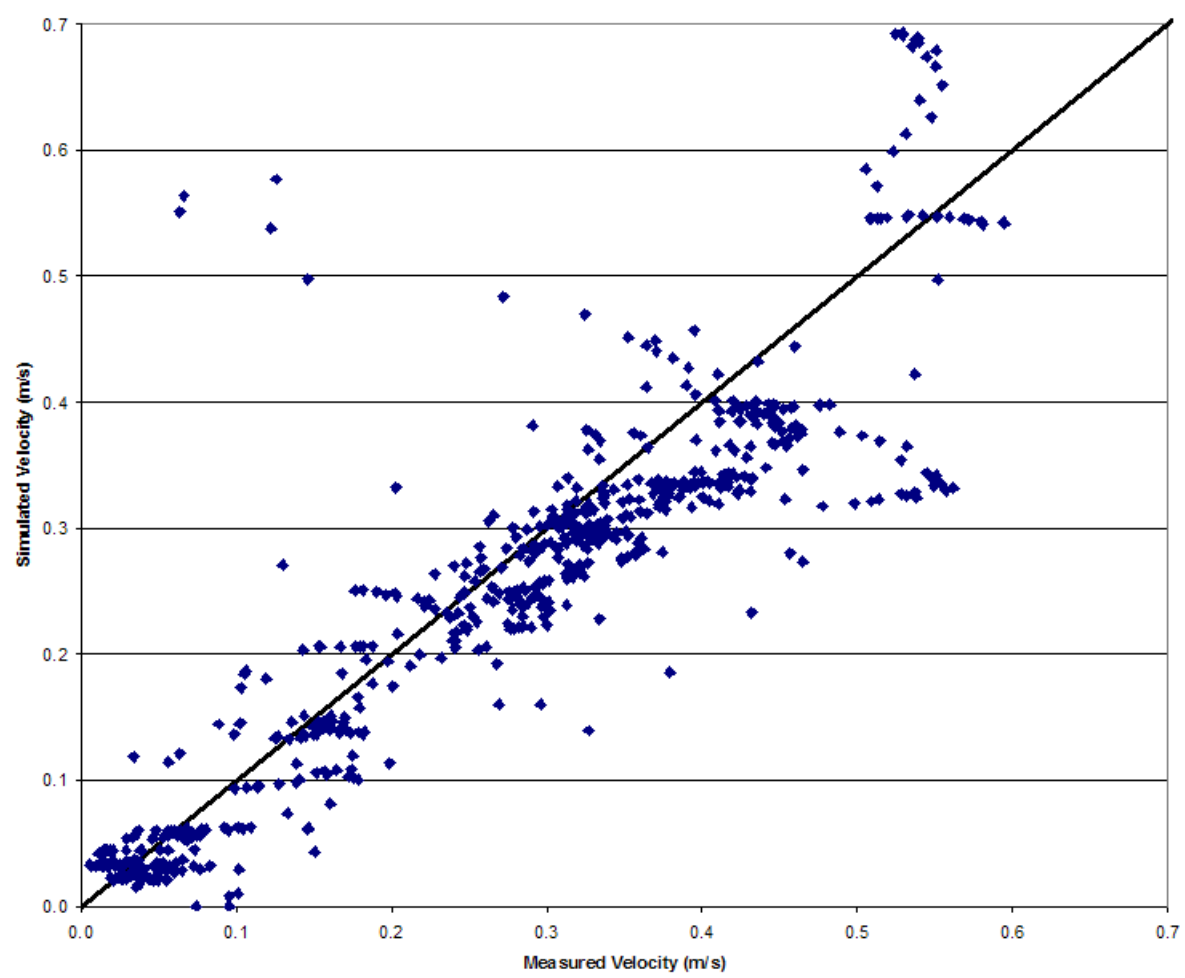

Figure 3.4. Comparison of velocity magnitudes for the ADCP measurements and numerical model results for April 6, 2003. Black line is the 1:1 line. 


\subsection{Preliminary Options}

The preliminary options were simulated for a single flow, and the results were compared for 1) the clean forebay, 2) a forebay with a BGS at a 45-degree to the powerhouse, and 3) a BGS at a 30-degree angle to the powerhouse. These runs were designed to show the potential impacts of the addition of a BGS structure on the flow field. For each run, a graphic with velocity vectors and contours of velocity magnitude was created for several elevations: 158, 150,140, 120, and $100 \mathrm{ft}$. In addition, a graphic with streamlines, colored by velocity magnitude, for massless particles released at 6-ft depth intervals was created. The complete set of graphics can be found in Appendix A. For the clean forebay, the overall flow pattern is generally determined by the total flow and the spill percentage (Figure 3.5).

Although many of the features shown in the simulation results for a structure in place were expected, the extent and persistence of the recirculation zone behind the BGS was not. The 45-degree BGS had a larger impact on the flows near the Washington shore than expected. This BGS placement had more streamlines, with higher velocities being displaced toward the Washington shore (compare Figures 3.6 and 3.7) than found in the clean forebay (Figures 3.5). Figure 3.8 shows a vertical slice through the water column perpendicular to the BGS structure with streamlines. The streamline that was seeded downstream of the structure gets entrained in recirculating flow that travels along the backside of the structure (see also Figure 3.7).

\subsection{Options 1 to 5}

Four proposed locations for a BGS structure were developed during the first trip to ERDC. These locations were incorporated into the numerical model, and runs were made for a suite of operational conditions (see Table 2.3). These CFD results were used in concert with the ERDC physical model of The Dalles forebay and to provide quantified metrics as part of the site selection process. A results package was provided to USACE CENWP and Agency (U.S. Geological Survey and NOAA's National Marine Fisheries Service) personnel prior to the June 2005 ERDC trip.

\subsubsection{Evaluation Metrics}

Evaluation metrics were developed in collaboration with USACE and Agency personnel. These metrics included evaluation of the general flow characteristics near the adult ladder (located just upstream of the powerhouse), lateral flow information along the BGS, flow velocities under the BGS, general forebay flow characteristics and impacts relative to the clean forebay, and vertical cross sections through the BGS. An elevation of $150 \mathrm{ft}$ (depth $8.6 \mathrm{ft}$ ) was chosen to be representative of the near-surface area of concern for the juvenile salmonids and was used as the elevation for visualization results and for the seeding of streamlines. In addition, the simulation results with streamlines into the non-overflow area are of concern. The non-overflow area is located between the powerhouse and the south end of the spillway. Visualizations and tabular data to address these areas were created for each simulation case and used to evaluate the options. Specifically, we used the CFD to determine the answerw to the following questions:

- General flow characteristics do or do not show an impact to the adult ladders? (yes/no) 


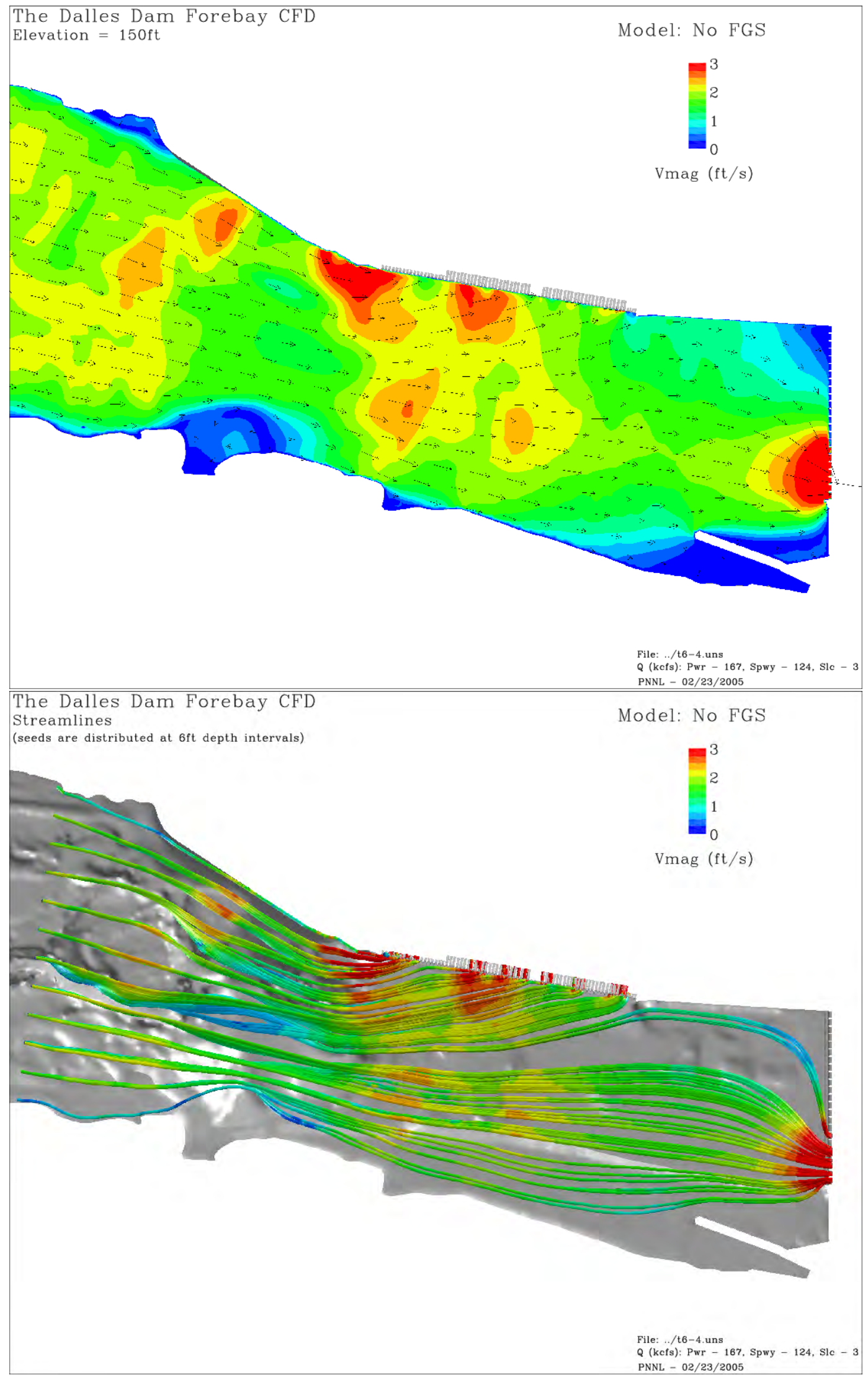

Figure 3.5. Preliminary clean forebay run for a Total River of $294 \mathrm{kcfs}, 42 \%$ spill. Vectors and contours of velocity (top) are at an elevation of $150 \mathrm{ft}$ (depth $8.6 \mathrm{ft}$ ). 


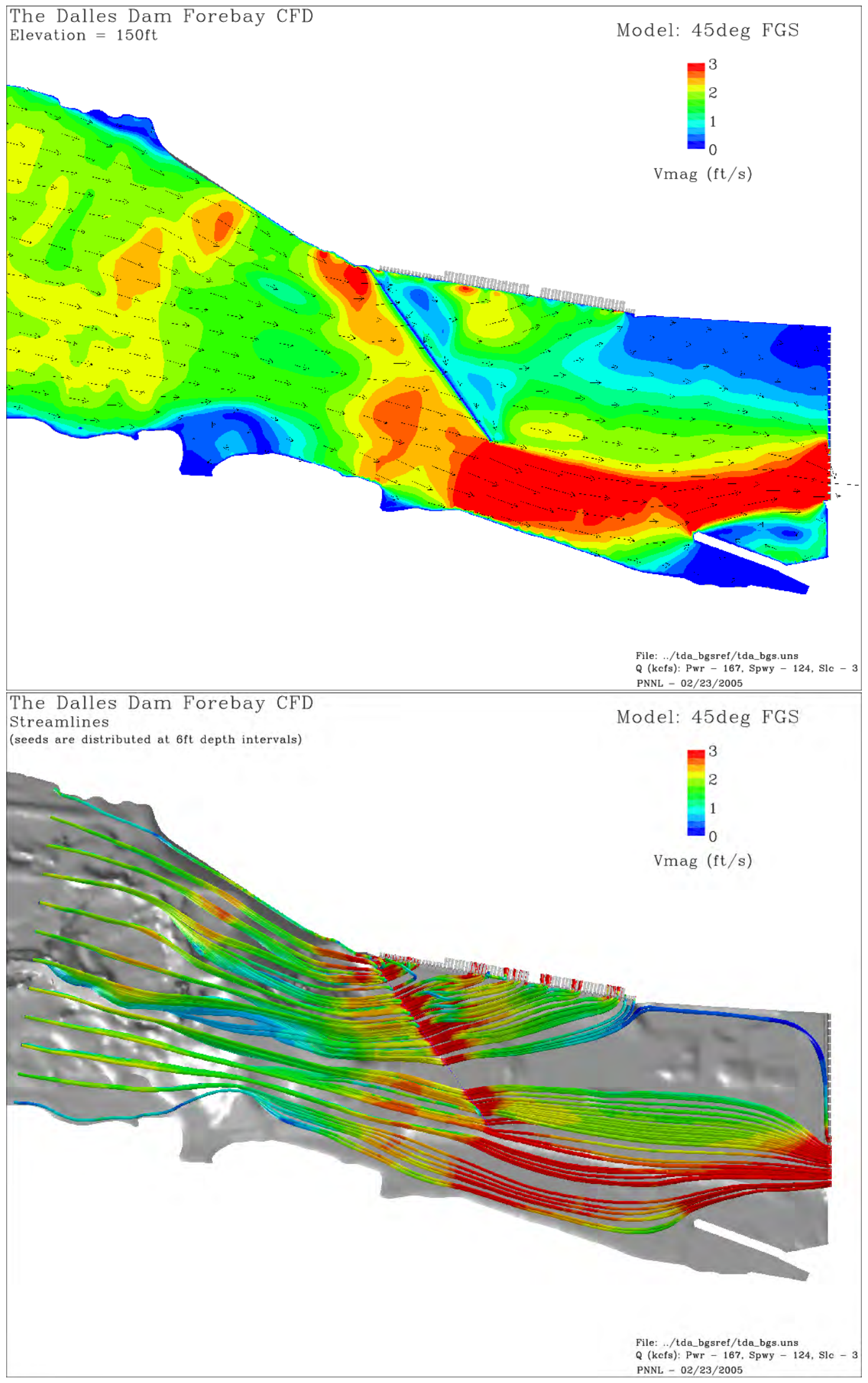

Figure 3.6. Preliminary run for a 45 -degree BGS for a Total River of $294 \mathrm{kcfs}, 42 \%$ spill. Vectors and contours of velocity (top) are at an elevation of $150 \mathrm{ft}$ (depth $8.6 \mathrm{ft}$ ). 


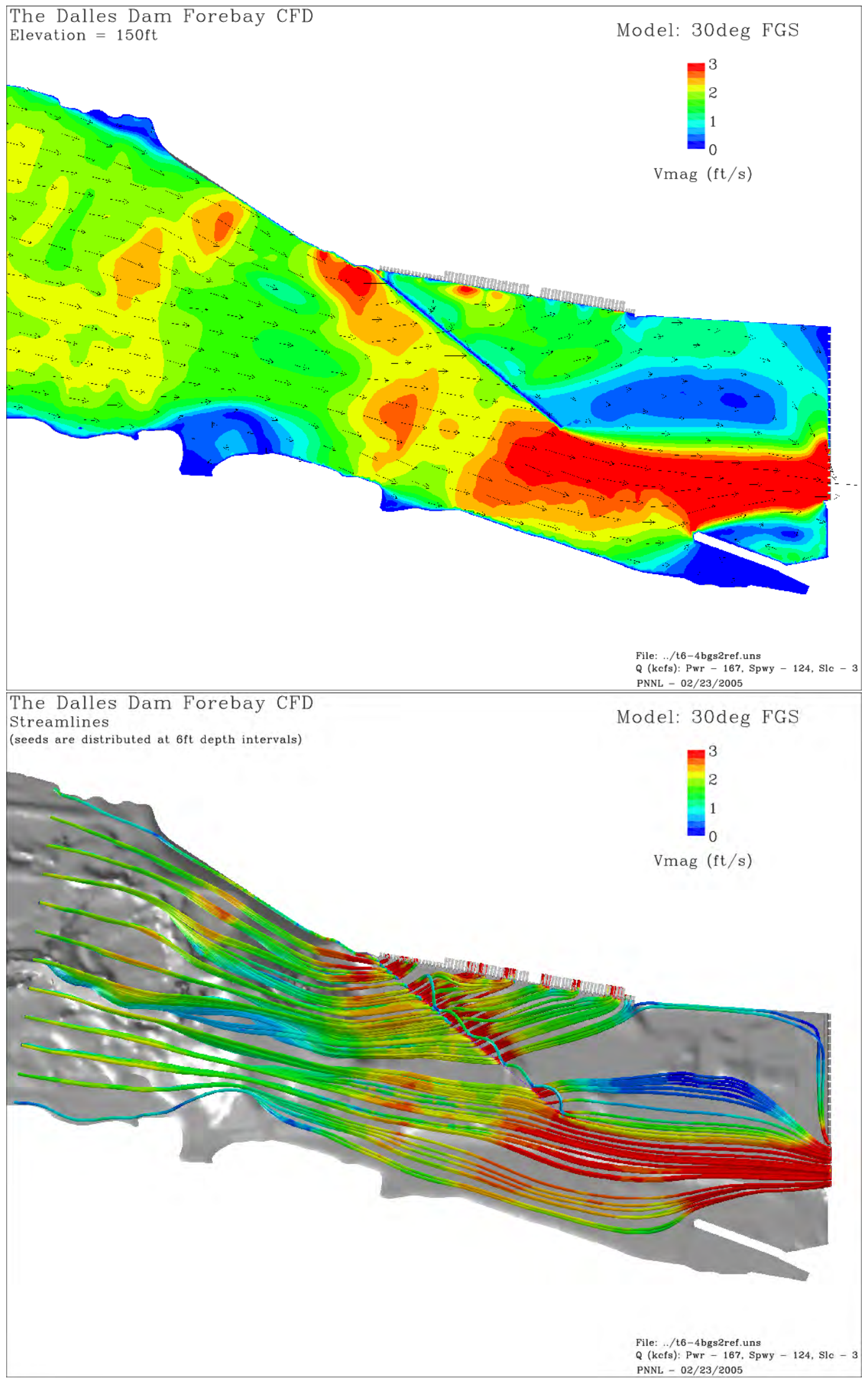

Figure 3.7. Preliminary run for a 30-degree BGS for a Total River of $294 \mathrm{kcfs}, 42 \%$ spill. Vectors and contours of velocity (top) are at an elevation of $150 \mathrm{ft}$ (depth $8.6 \mathrm{ft}$ ). 


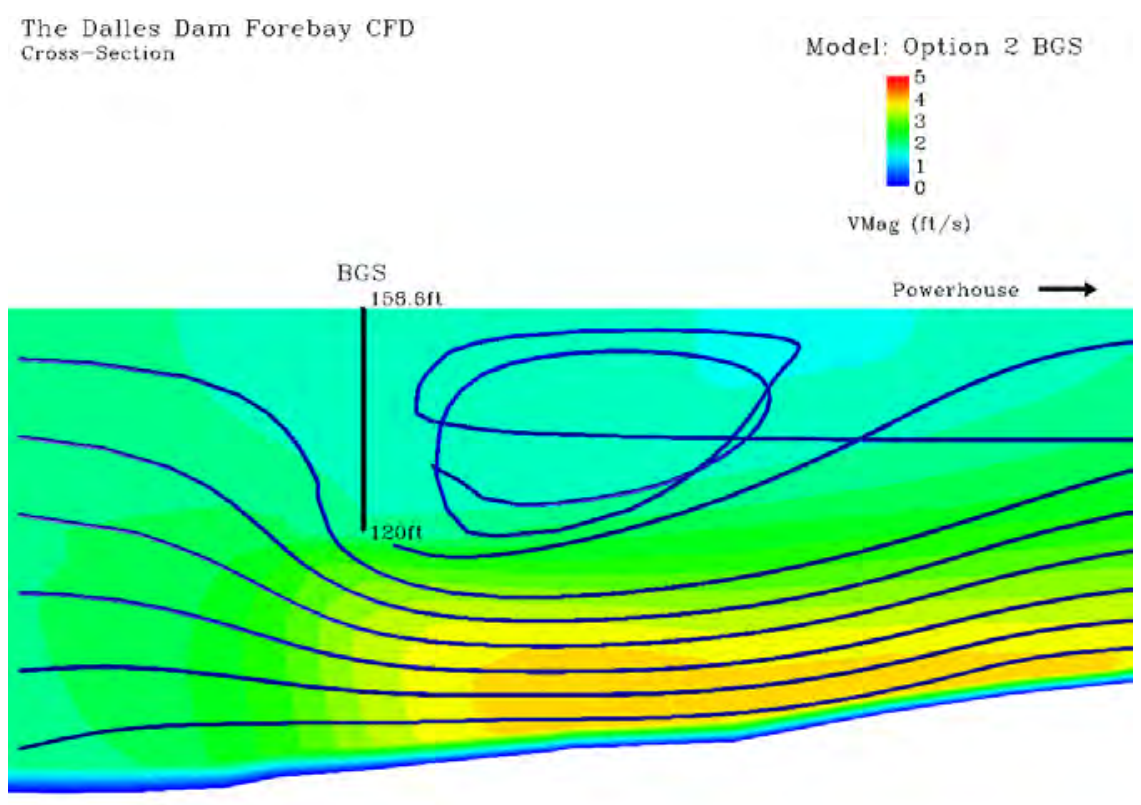

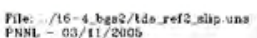

Figure 3.8. Helical recirculation along the backside of the BGS was a consistent feature of these simulations.

- Lateral flow along the BGS is larger than the perpendicular flow directed at the BGS? (yes/no)

- Flow under the BGS is 2 fps or larger? (yes/no)

- The flow characteristics along the powerhouse are impacted by the BGS relative to a clean forebay (negatively, neutral, positive)

- The vertical cross section through the BGS is similar to the Lower Granite BGS vertical cross section? (yes/no)

- Flow lines end up in the non-overflow area? (yes/no).

\subsubsection{Simulation Results}

The numerical model with a clean forebay was run to compare with the BGS scenarios for Options 1 to 4 for the potential impacts on the flow fields. In addition, the clean forebay model was run and the simulation results were "seeded" with neutrally-buoyant particles in the spillway, sluiceway, and powerhouse intakes and the streamlines from these particle propagated backward. Our purpose was to graphically show the general extent of the forebay flow field that would need to be intercepted by a BGS to have the desired result. In reality, these are only a general indication of where the particles orginate upstream, as this method ignores turbulent dispersion.

An example of this reverse streamline tracking is shown in Figure 3.9; additional figures are in 
Appendix B, Figures B.1 through B.6. The green streamlines are for particles that originate in the spillway (Bays 1 through 6), red in the turbine intakes, and blue in the open sluiceway over Main Unit 1. The proposed BGS locations were overlaid on these streamlines to indicate which alignments had potential to intercept juvenile salmonids that would pass through the powerhouse. Partly on the basis of these graphics, it was determined that the Option 4 alignment would have a low likelihood of intercepting many fish and guiding them away from the powerhouse.

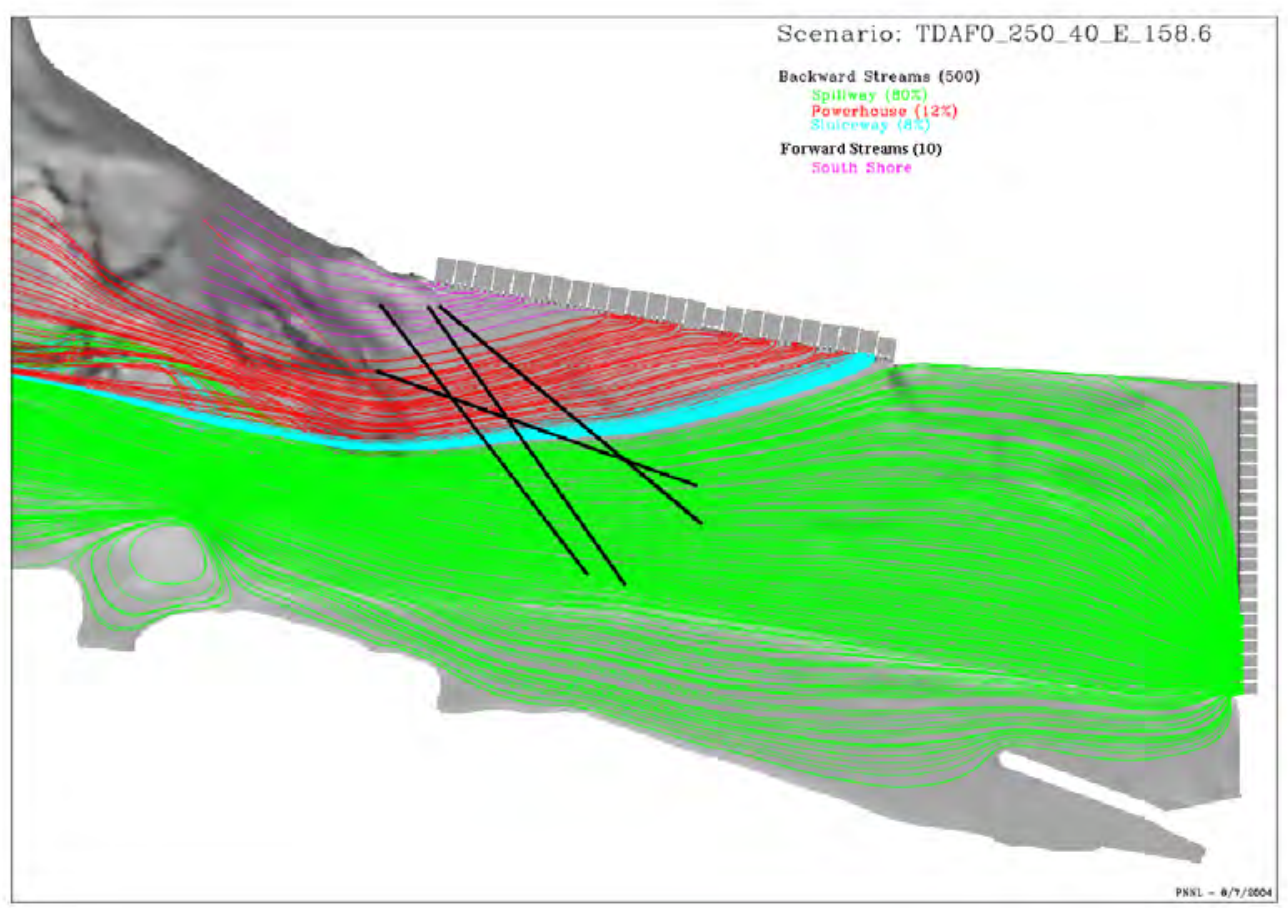

Figure 3.9. Particle tracks for Total River $250 \mathrm{kcfs} 40 \%$ spill, standard powerhouse operation

To increase the utility of the numerical results, graphics were prepared that compared the given option and total river flow at $20 \%$ spill to the clean forebay at 20 and $40 \%$ spill for the same total river flow. These visualizations were prepared as $11 \times 17$ plates (see Appendix $B$ for an $8.5 \times 11$ version of these plates); each plate consists of a 9-plot matrix of figures (e.g., Figure 3.10). The center column of figures show the simulation results for a BGS scenario. The left and right columns show the simulation results for no-BGS scenarios with 40- and 20-\% spill conditions, respectively, for the same total river flow. The first row shows velocity vectors and contoured velocity magnitude at elevation $152 \mathrm{ft}$, the second row streamlines seeded just downstream of Big Eddy at elevation $152 \mathrm{ft}$, and the third row velocities at specified locations developed as part of the evaluation metrics. One set of points lies about $30 \mathrm{ft}$ from the face of the powerhouse 
and upstream of the BGS about $4 \mathrm{ft}$ below the surface. Another set of points lies $7 \mathrm{ft}$ directly beneath the bottom of the BGS. Tables of the values of the velocity components parallel and perpendicular to the BGS and to the powerhouse at these points are presented in Appendix B, Tables B.1 through B.7. On the plates, the red and blue dots on the powerhouse and spillway indicate which units are on or off, respectively.

Additional information was desired for the effect of seed distance from the BGS for particle tracking. Figures were created with three seed locations on the upstream side of the BGS at four distances from the face of the BGS (e.g., Option 1 is shown in Figure 3.11) for the Total River 250 kcfs with $20 \%$ spill for Options 1 through 4 . These figures show the streamlines followed by neutrally buoyant particles; the streamlines are colored by the distance of the release location from the BGS. The complete set of figures is in Appendix B.

For Option 1 (Figure 3.11), the streamlines for particles released at the upstream end of the BGS went under the BGS, then spiraled along the backside of the BGS to the downstream end to egress the model (for all but one particle) through the spillway. Those released in the middle of the BGS went under the BGS and left the model through the powerhouse. The streamlines from the downstream end went directly to the spillway. For Option 2 (Figure B.18), all particles at both elevations egressed the model through the powerhouse. For Option 3 (Figure B.26), most of the particles egressed the model through the powerhouse. However, most of the particles from the higher elevation $(148 \mathrm{ft}$ ) released at the downstream end of the BGS egressed the model through the spillway. For Option 4 (Figures B.33), all particles egressed the model through the powerhouse.

The concept behind the placement of the BGS is that fish do not behave as neutrally buoyant particles but rather tend to stay nearer to the surface and be guided by the BGS to its downstream end. To illustrate this point, particle tracking simulations were performed using neutrally buoyant massless particles. Particle trajectories were computed using the velocity and turbulence fields simulated by the CFD model for the Option 2 operating conditions. A key feature included in the particle tracking code is the ability to assign a so-called depth-preference to the particle that allows a particle to move with the flow but also undergo a restoring velocity that tends to move the particle back toward its preferred depth. The "strength" is the rate at which the particle moves back toward the preferred depth. The effect is similar to observing the movement of floating confetti in a physical model. A "strong" preference will not allow the particle to wander very far from the assigned depth, while a "weak" preference may allow the particle to move to much greater depths in zones of large vertical velocities. Note that these particles are not fish and fish do not necessarily move along fluid streamlines.

Figure 3.12 shows particle tracking results that includes a depth preference of $2 \mathrm{~m}$. The particles with a strong preferred depth of $2 \mathrm{~m}$ tend to be guided along the BGS and ultimately exit the model domain through the spillway. Particles with a weak $2 \mathrm{~m}$ depth preference are delayed briefly in front of the BGS and then pass below. Increased particle dispersion behind the BGS is caused by the larger amount of turbulence generated in the wake of the BGS. Particles exit the model domain through turbine intakes and the sluiceway. Note that one particle gets caught in a dead zone in a nonoperating spillbay. These results demonstrate the importance of understanding how juvenile salmon will respond to a structure like the BGS. If juvenile salmon follow streamlines and move downward rather than being surface oriented, the BGS may not be as 


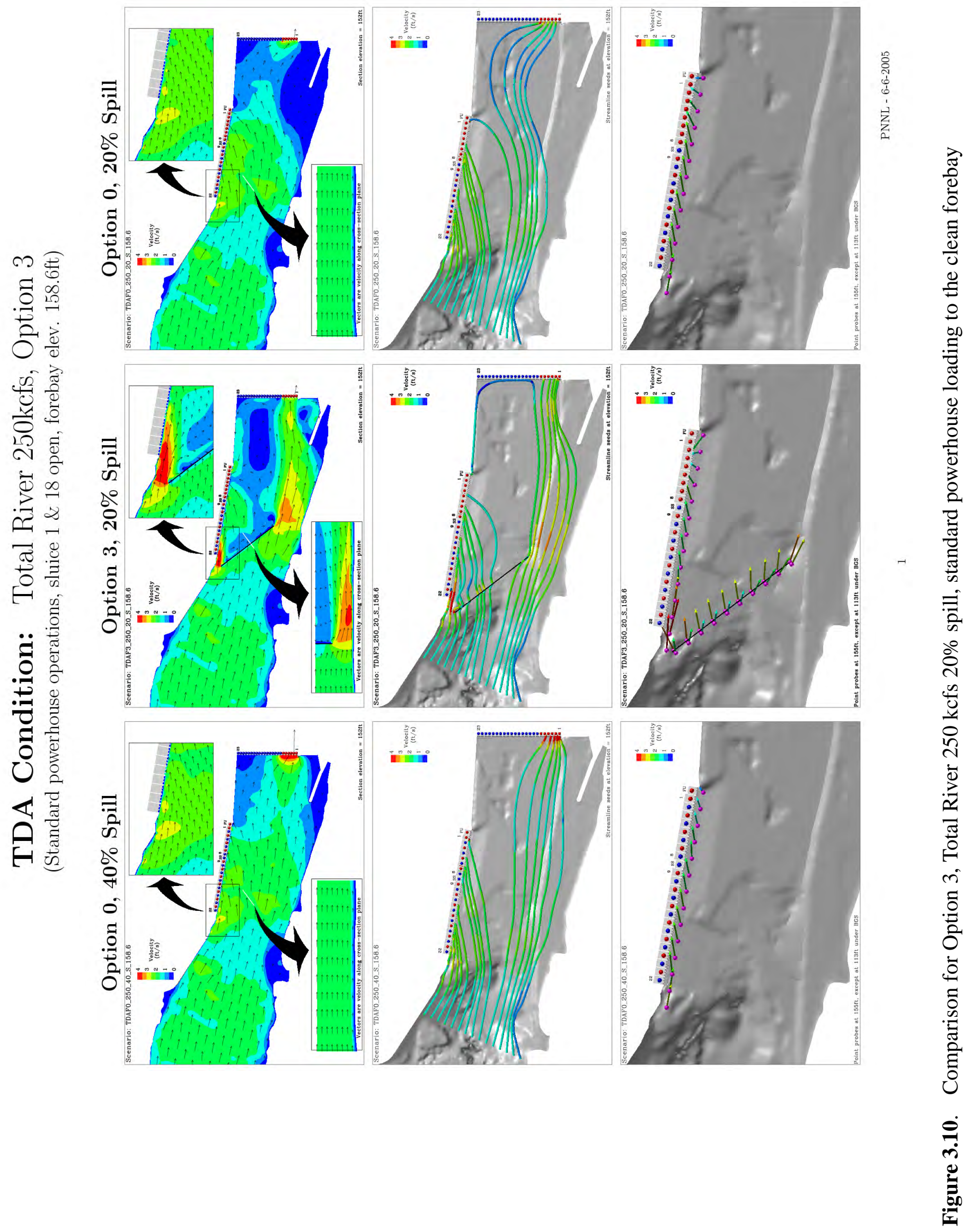



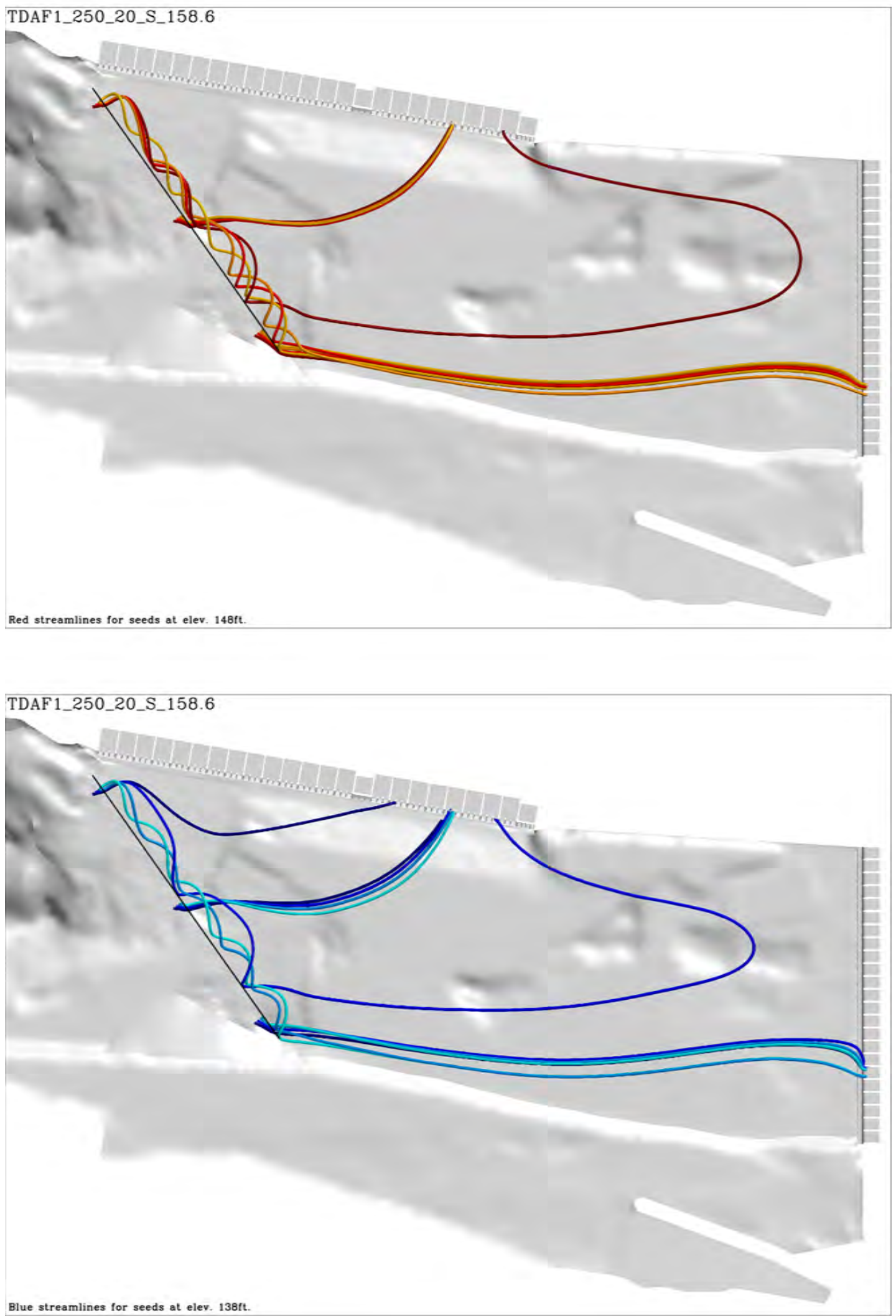

Figure 3.11. Option 1 streamlines for Total River $250 \mathrm{kcfs} 20 \%$ spill, standard powerhouse loading at elevation $148 \mathrm{ft}$ (top) and $138 \mathrm{ft}$ (bottom) 
effective in guiding fish toward the spillway bays 1 through 6 .

If juvenile salmonids are guided by the BGS structure rather than following the streamlines underneath the structure, the fate of water from the downstream end of the BGS would be an indication of the egress location of the guided fish. Table 3.4.2 summarizes the fate of streamlines from the end of the BGS for the simulated scenarios. This table was developed from the plates in Appendix B. When looking at the set of graphics in Appendix B it is important to ascertain if the streamlines are going around or passing beneath the downstream end of the BGS. This depth dependent difference is most critical for Option 3, where many of the streamlines pass underneath the BGS near its downstream end, then exit through the powerhouse. The parenthetical values in Table 3.4.2 under Option 3 indicate flow scenarios for which this is the case. Figure 3.13 shows an oblique view of streamlines seeded through the water column near the downstream end of the BGS for Option 1 and Option 3 for a total river discharge of $250 \mathrm{kcfs}$. Figure 3.13 clearly shows the depth dependence of particle fate, especially for Option 3.

Table 3.1. Streamline fate from the end of the BGS. In this table, powerhouse egress is indicated by "P", spillway egress is indicated by an " $\mathrm{S}$ ".

\begin{tabular}{ccccccc}
\hline Total River & Spill \% & PH Operation & ${ }^{(a)}$ Option 1 & Option 2 & Option 3 & (b) Option 4 \\
\hline 150 & 20 & 1 & $\mathrm{~S}$ & $\mathrm{P}$ & $\mathrm{S}(\mathrm{P})$ & $\mathrm{P}$ \\
200 & 20 & 1 & $\mathrm{~S}$ & $\mathrm{P}$ & $\mathrm{S}$ & $\mathrm{P}$ \\
250 & 40 & 1 & $\mathrm{~S}$ & $\mathrm{~S}$ & $\mathrm{~S}$ & $\mathrm{~S}$ \\
250 & 20 & 1 & $\mathrm{~S}$ & $\mathrm{P}$ & $\mathrm{S}(\mathrm{P})$ & $\mathrm{P}$ \\
250 & 20 & 2 & $\mathrm{~S}$ & & $\mathrm{~S}(\mathrm{P})$ & \\
300 & 20 & 1 & $\mathrm{~S}$ & $\mathrm{P}$ & $\mathrm{S}(\mathrm{P})$ & $\mathrm{P}$ \\
350 & 20 & 1 & $\mathrm{~S}$ & $\mathrm{P}$ & & \\
\hline
\end{tabular}

(a) PH Operation 1 indicates standard loading, Operation 2 indicates East end loading.

(b) The $(\mathrm{P}) \mathrm{s}$ indicate that the figures show particles that pass under the BGS near the downstream end that exit the model through the powerhouse. However, if particles are seeded at the end of the BGS, streamlines exit through the spillway. PH Operation 1 indicates standard loading, Operation 2 indicates East end loading.

The plates from Options 1 through 4 (shown in Appendix B) were used during the June ERDC trip to the 1:80 physical scale model during further refinement and evaluation of the proposed BGS locations. These figures and tables, in conjunction with observations of the physical model and USGS biological data, were used to winnow the proposed BGS locations and to refine the physical model scenarios.

A consistent feature of the CFD results was that a $20 \%$ spill flow produced undesirable flow features, especially in the area adjacent to the non-overflow dam. Those features included streamlines from the end of the BGS that exited the model through the powerhouse. Based on the CFD results, it was decided that the $20 \%$ spill scenarios would not provide adequate guidance from the end of the BGS to the spillway. Consequently, the lowest spill considered during June 2005 ERDC 1:80 physical model trip was $30 \%$. 
BGS Option 2

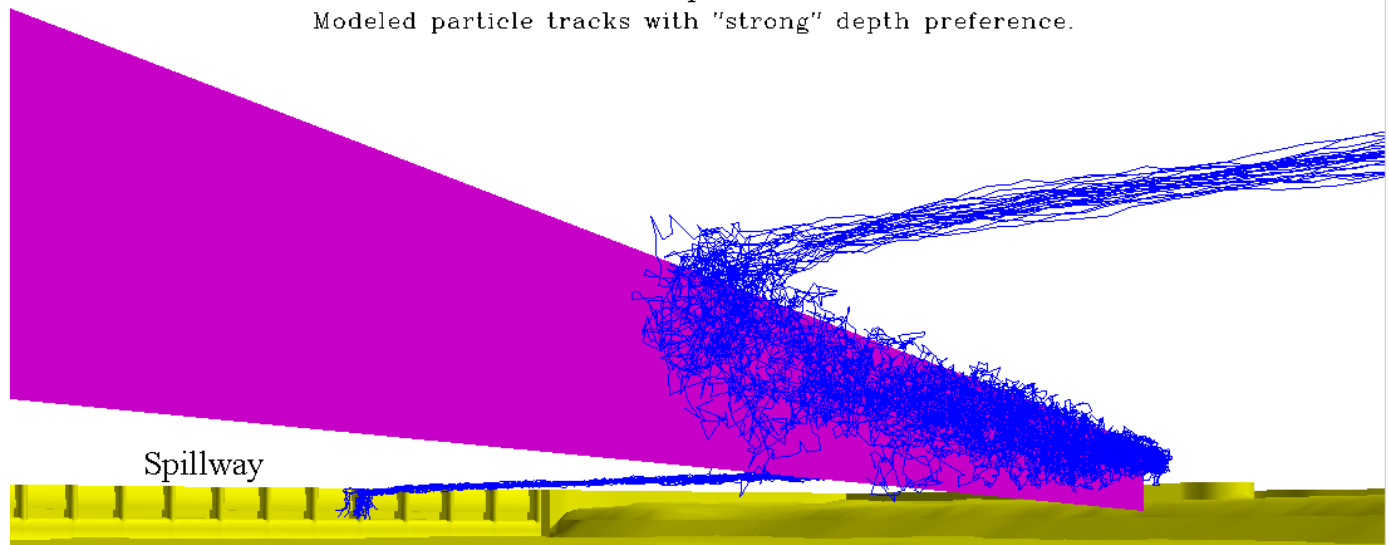

BGS Option 2

PNNL $-3 / 11 / 2005$

Modeled particle tracks with "weak" depth preference.

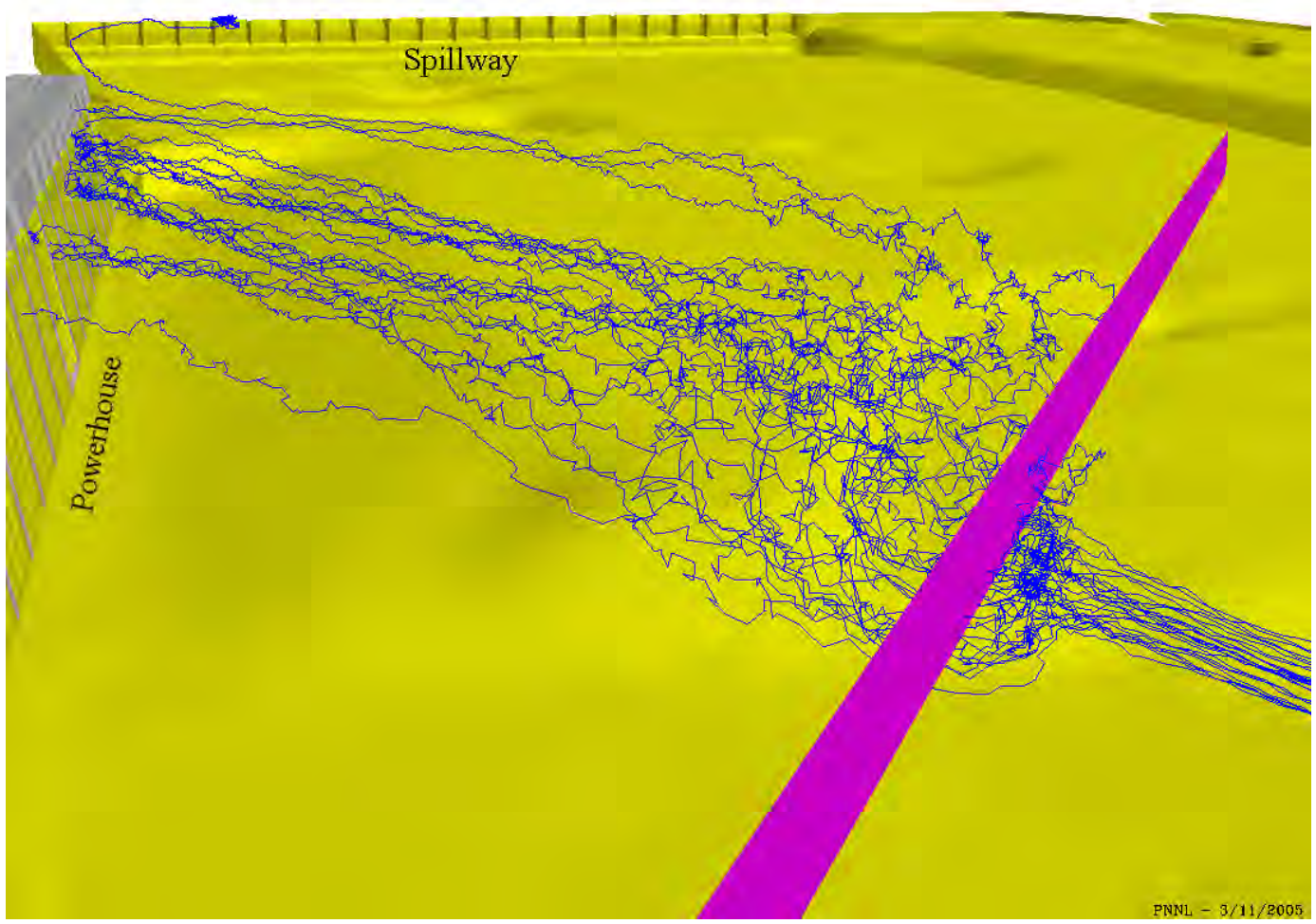

Figure 3.12. Particle tracking in The Dalles forebay for particles with a strong depth preference (top) and a weak depth preference (bottom) 


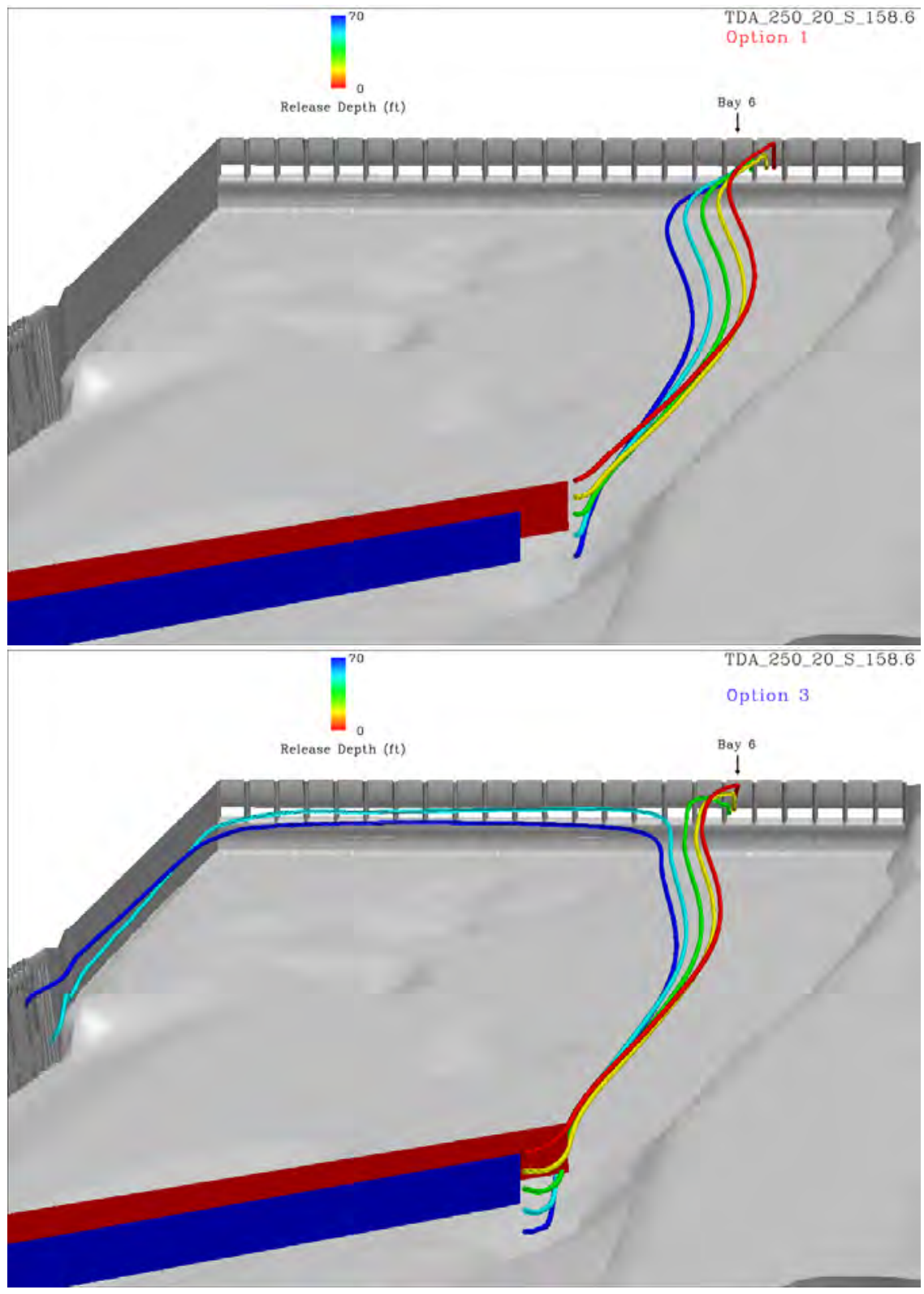

Figure 3.13. Streamlines from BGS ends for a Total River of $250 \mathrm{kcfs}, 20 \%$ spill, water surface elevation $158.6 \mathrm{ft}$ for Options 1 (top) and 3 (bottom). The streamlines are colored by release depth. Both BGS locations are shown for clarity. Option 1 is in red, Option 3 in blue. 
Good agreement was observed between the CFD results and the physical model, providing confidence in both hydraulic tools. During that trip, participants (USACE and Agency personnel) scored and eliminated options based on CFD results, 1:80 physical model observations, and USGS data from biological sampling(Cash et al.2005). The alignment selection is documented in the trip report. The final alignment was Option 14. Its final length and draft were to be subsequently determined using the CFD model.

\subsection{Option 14}

The Option 14 simulations were used to determine the minimum acceptable length of the BGS and, in conjunction with biological studies, the appropriate depth below the water surface. The complete series of visualizations is in Appendix C

\subsubsection{Length and Depth Determination}

The first task was determination of a length adequate to divert fish to the spillway. The simulations were run for a single operational scenario (200 kcfs with $30 \%$ spill) for the $20-, 30-$, and 40-ft draft BGS for the proposed lengths. Particles were seeded at the downstream end of the BGS for each length, and visualizations of the streamlines produced (Figures 3.14 and 3.15). It was determined from smolt survival studies that it is more desirable to have fish pass through the center spillway bays (and not Bay 6) because higher mortality was observed in fish passing through that bay. Bay 6 is typically the last spillway open because of the placement of the spillwall in the tailrace. The purpose of the spillwall is to enhance survival of juvenile salmon passing through the spillway by improving spillway egress. From the USGS acoustic telemetry data (Cash et al.2005), it was determined that the 40-ft draft would be needed to intercept the desired proportion of the fish.

The results from the CFD simulations showed that the 1600-ft length was the minimum length needed with a 40-ft draft (Figure 3.15, top). In addition, a sensitivity analysis was done to see if small changes in the streamline seed location affected the location of egress from the model (Figure 3.16). Even when particles were seeded with a 5-m spacing, the difference in egress location was less than half the width of a spillbay. 


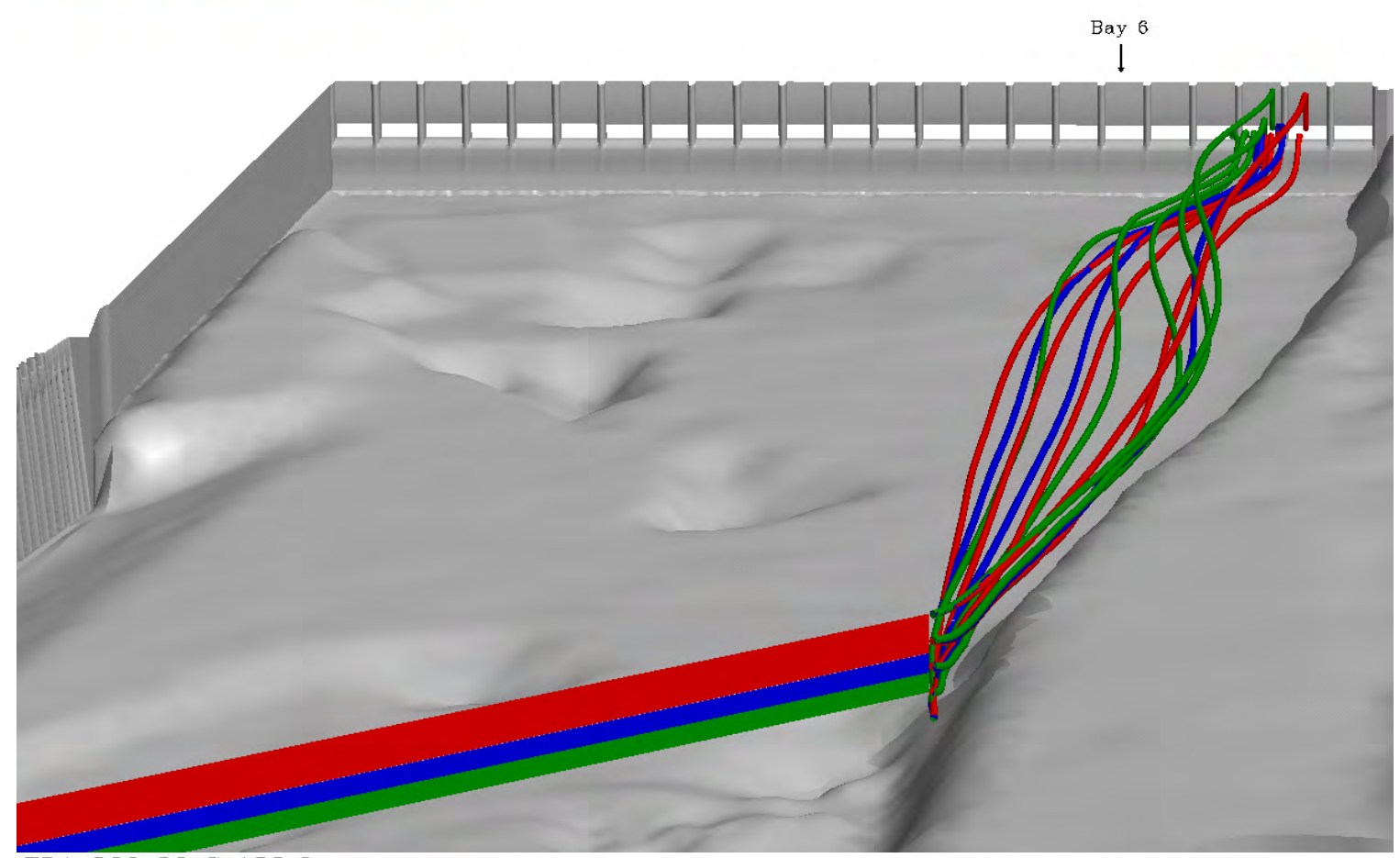

TDA_200_30_S_158.6

Option 14, Length 1700ft, Draft 20ft

Option 14, Length $1700 \mathrm{ft}$, Draft $30 \mathrm{ft}$
Option 14, Length $1700 \mathrm{ft}$, Draft $40 \mathrm{ft}$

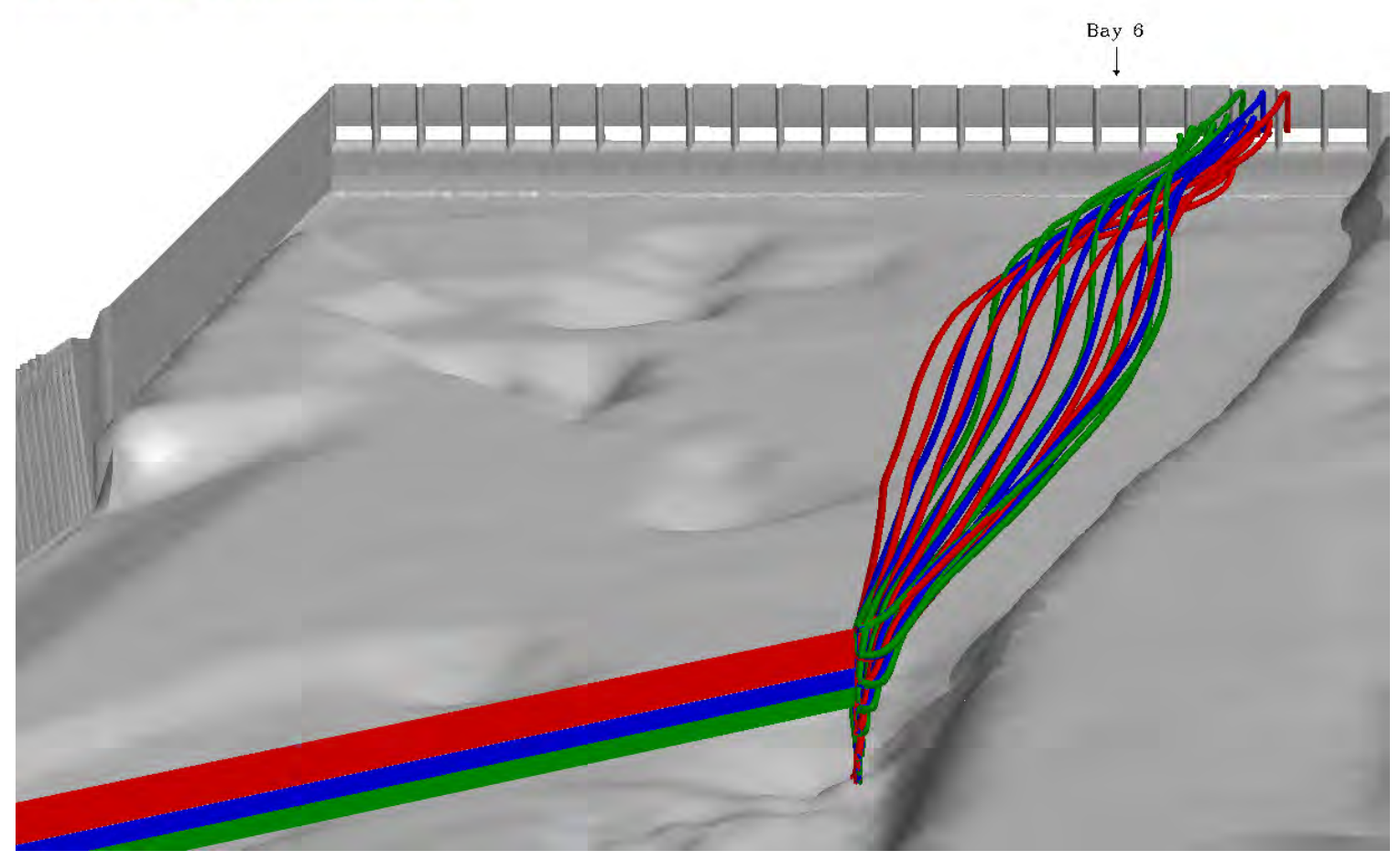

Figure 3.14. Streamlines from BGS ends for a Total River of $200 \mathrm{kcfs}, 30 \%$ spill. The streamlines are colored by release depth for the 1800-ft (top) and 1700-ft (bottom) BGS. 


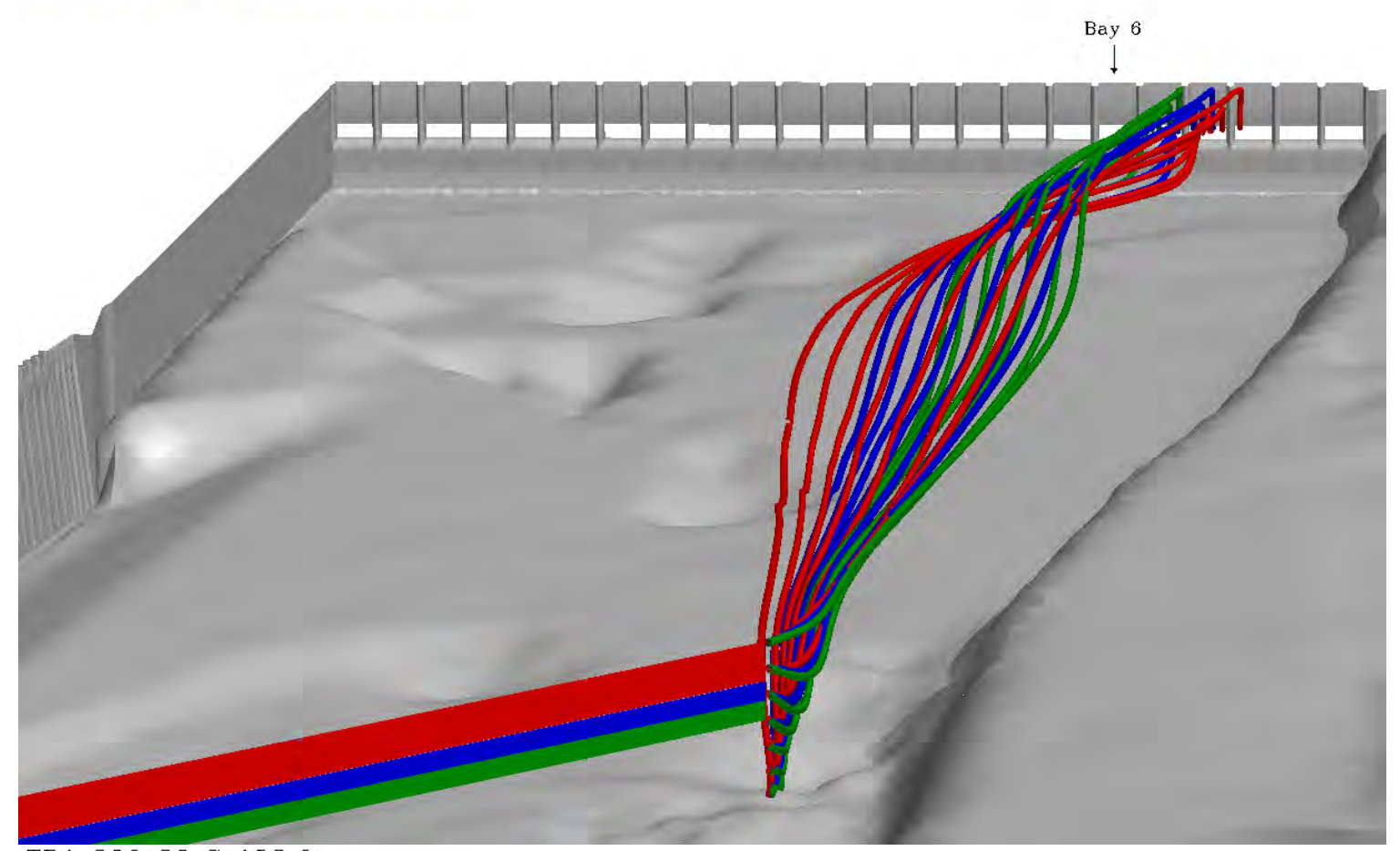

\section{TDA_200_30_S_158.6}

Option 14, Length $1500 \mathrm{ft}$, Draft $20 \mathrm{ft}$

Option 14, Length $1500 \mathrm{ft}$, Draft $30 \mathrm{ft}$

Option 14, Length $1500 \mathrm{ft}$, Draft $40 \mathrm{ft}$

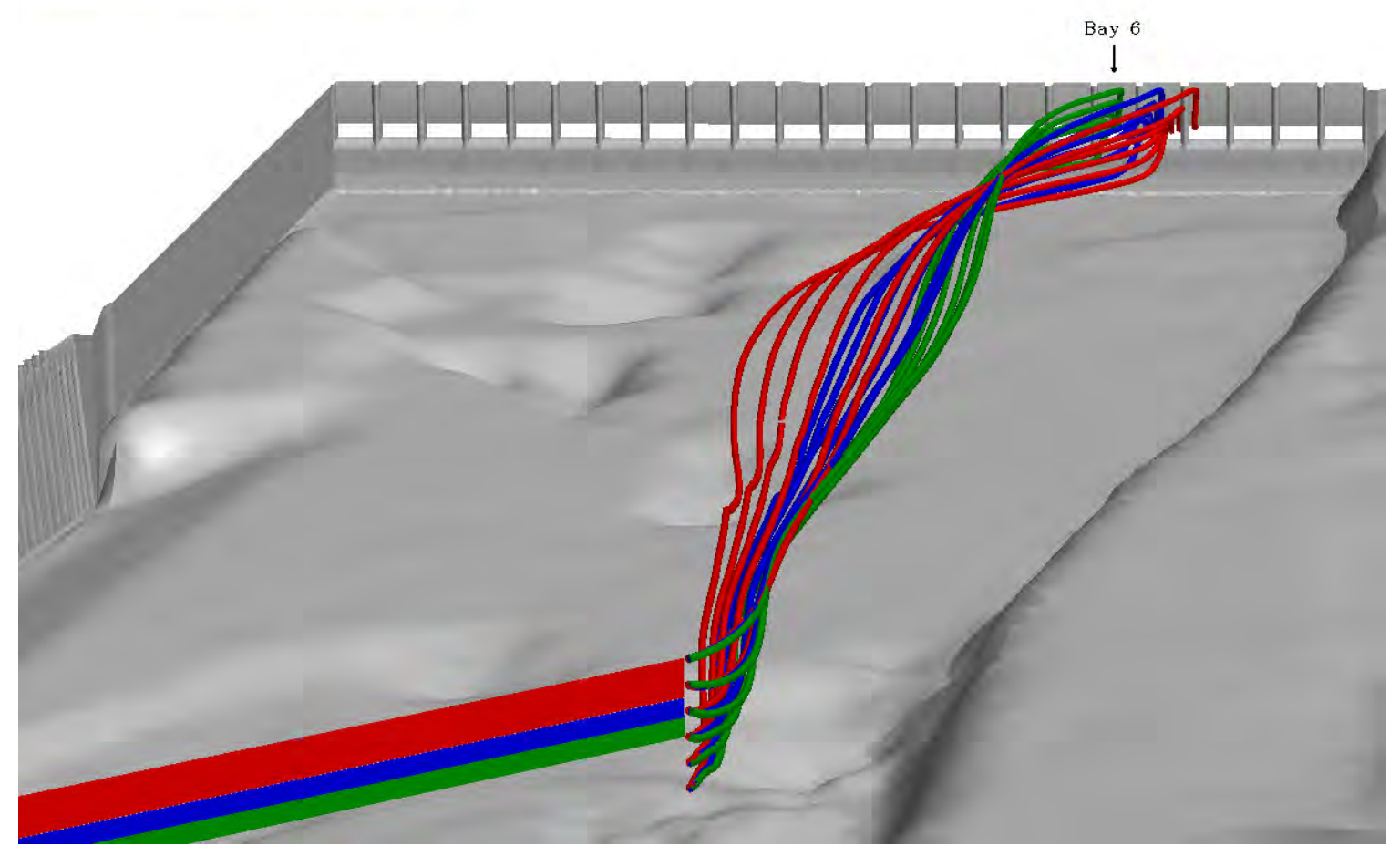

Figure 3.15. Streamlines from BGS ends for a Total River of $200 \mathrm{kcfs}, 30 \%$ spill. The streamlines are colored by release depth for the 1600-ft (top) and 1500-ft (bottom) BGS. 


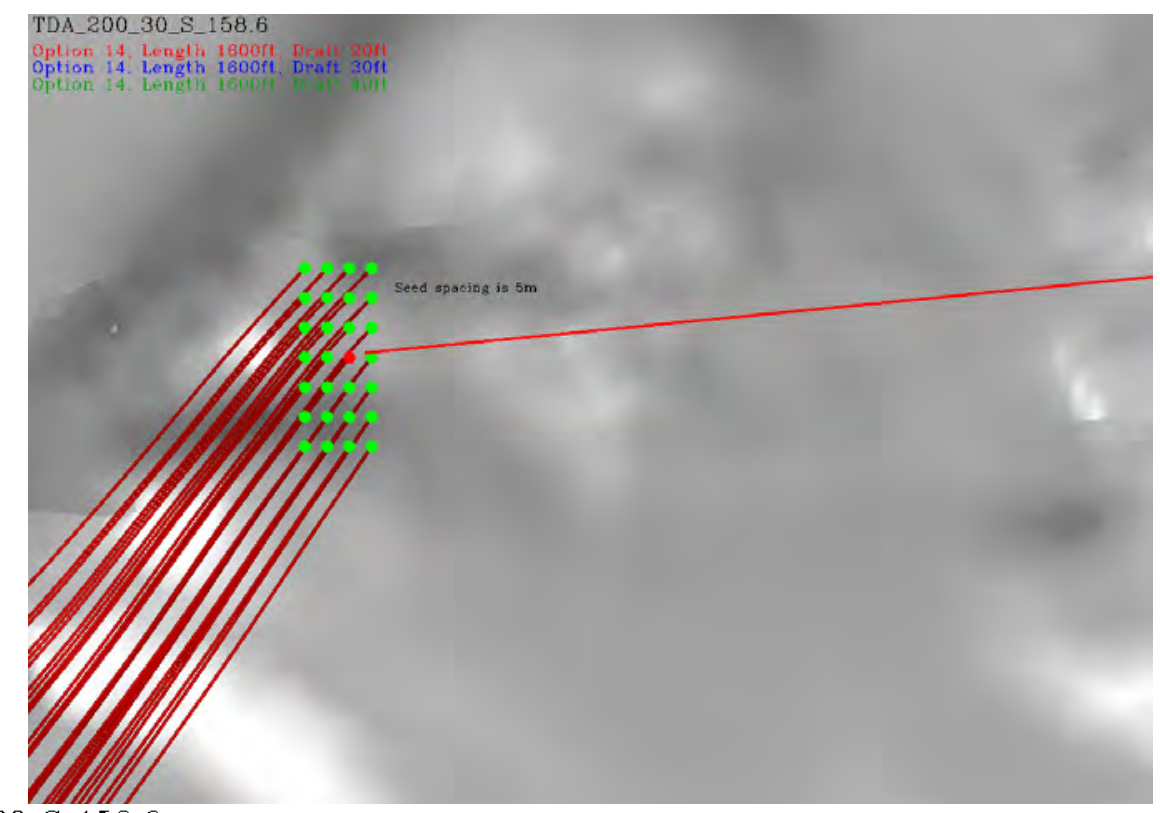

TDA_200_30_S_158.6

Option 14, Length $1600 \mathrm{ft}$, Draft $20 \mathrm{ft}$

Option 14, Length $1600 \mathrm{ft}$, Draft $30 \mathrm{ft}$

Option 14, Length $1600 \mathrm{ft}$, Draft $40 \mathrm{ft}$

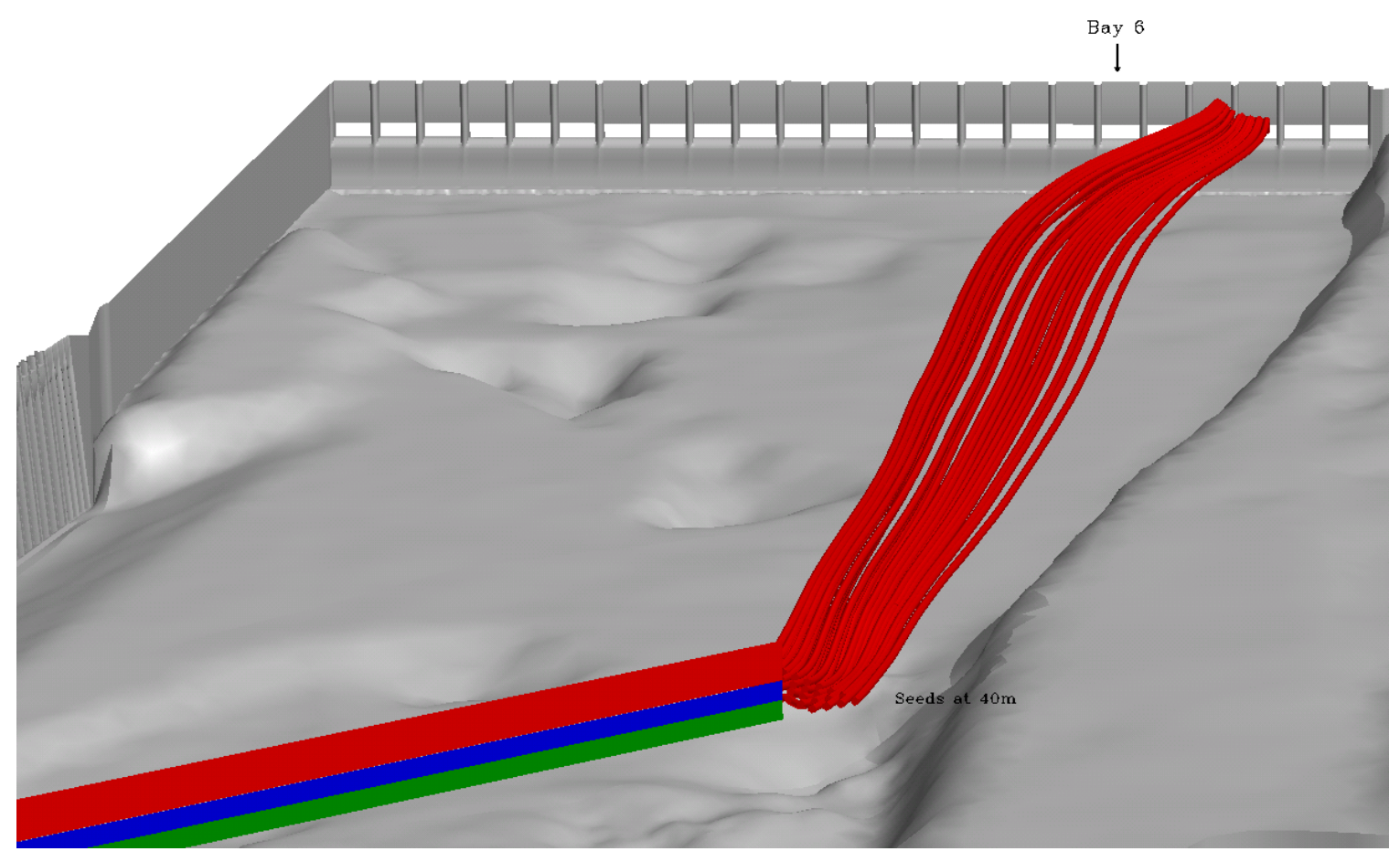

Figure 3.16. Sensitivity to seed location for streamlines from the end of a 1600-ft BGS for a Total River of $200 \mathrm{kcfs}, 30 \%$ spill 


\subsubsection{Additional Simulations}

Additional simulations of floods flows with a BGS in place were requested to support the design of the BGS by USACE CENWP. All load calculations were done by USACE engineers. Figure 3.17 shows velocity vectors and magnitudes in the forebay with a flow of $680 \mathrm{kcfs}$ for a $30-\mathrm{ft}$ (top) and 40-ft (bottom) BGS. All flow passed the project via the spillway.

An additional configuration of the Option 14 BGS, with the upstream section of the BGS angled into the flow, was modeled. This design was expected to reduce the very large loads on the upstream section of the BGS. All load analyses were performed by USACE CENWP. Figures 3.18 and 3.19 show velocity vectors and magnitude for the three simulations at an elevation of $150 \mathrm{ft}$. Note the velocity magnitudes scales differ between the figures.

A computational mesh for a tilted BGS was created for additional flood loading calculations. The computational mesh was provided to CENWP, and all simulations and load calculations were completed by USACE CENWP.

A model of a 1600-ft BGS with 2-ft gaps every $100 \mathrm{ft}$ was also requested. Separating the BGS into sections was considered as a way to reduce the connector load. Vector and contour plots at an elevation of $150 \mathrm{ft}$ are shown in Figures 3.20 and 3.21 for 150-, 200-, 250-, and 300-kcfs Total River with $30 \%$ spill.

\subsubsection{Simulations to Investigate Navigation Issues}

Further evaluation of the final Option 14 BGS length and draft at the ERDC 1:80 physical model determined that this configuration resulted in negative impacts on navigation. Experienced Columbia River pilots had difficulting successfully navigating the forebay and the navigation lock when the physical model was modified with a BGS.

Additional runs of the CFD model were requested to address the possibility of using a shorter BGS. Figure 3.22 shows vectors and velocity magnitudes for BGS lengths of 1000 and $1100 \mathrm{ft}$ at an elevation of $150 \mathrm{ft}$. It should be noted that the greatest differences between the physical model and prototype bathymetry are between Big Eddy and the Washington shore and the area just downstream (Figure 3.1). This would be and area where the CFD and 1:80 physical model would show differences in local velocities. These areas will influence the hydraulics around the BGS and the navigation channel. A complete set of figures for all lengths is in Appendix D, Figures D.1 through D.5. 

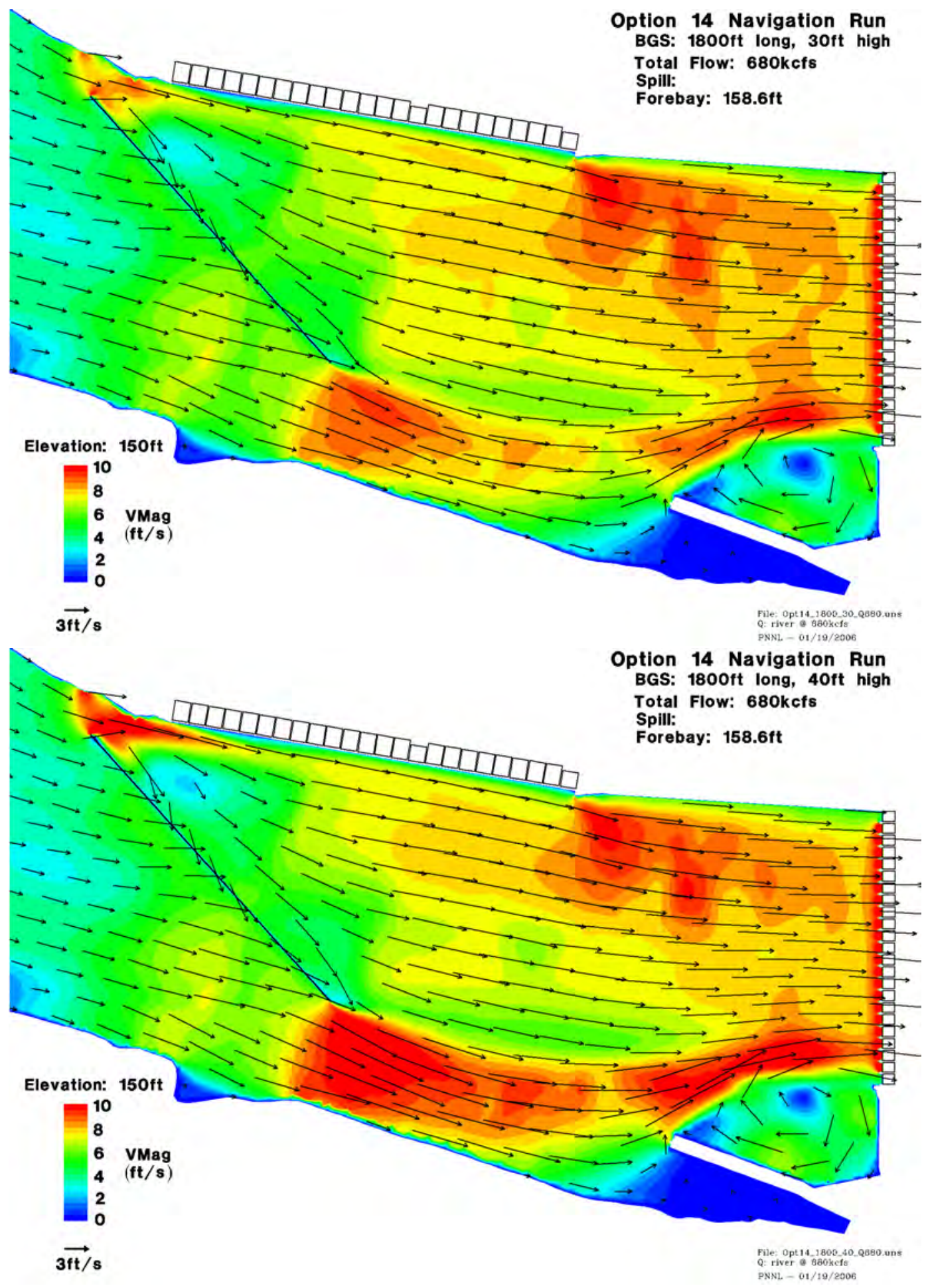

Figure 3.17. Simulation results for a 1800-ft BGS for a Total River of $680 \mathrm{kcfs}$ with $30 \%$ spill (top) and 40\% spill (bottom). 


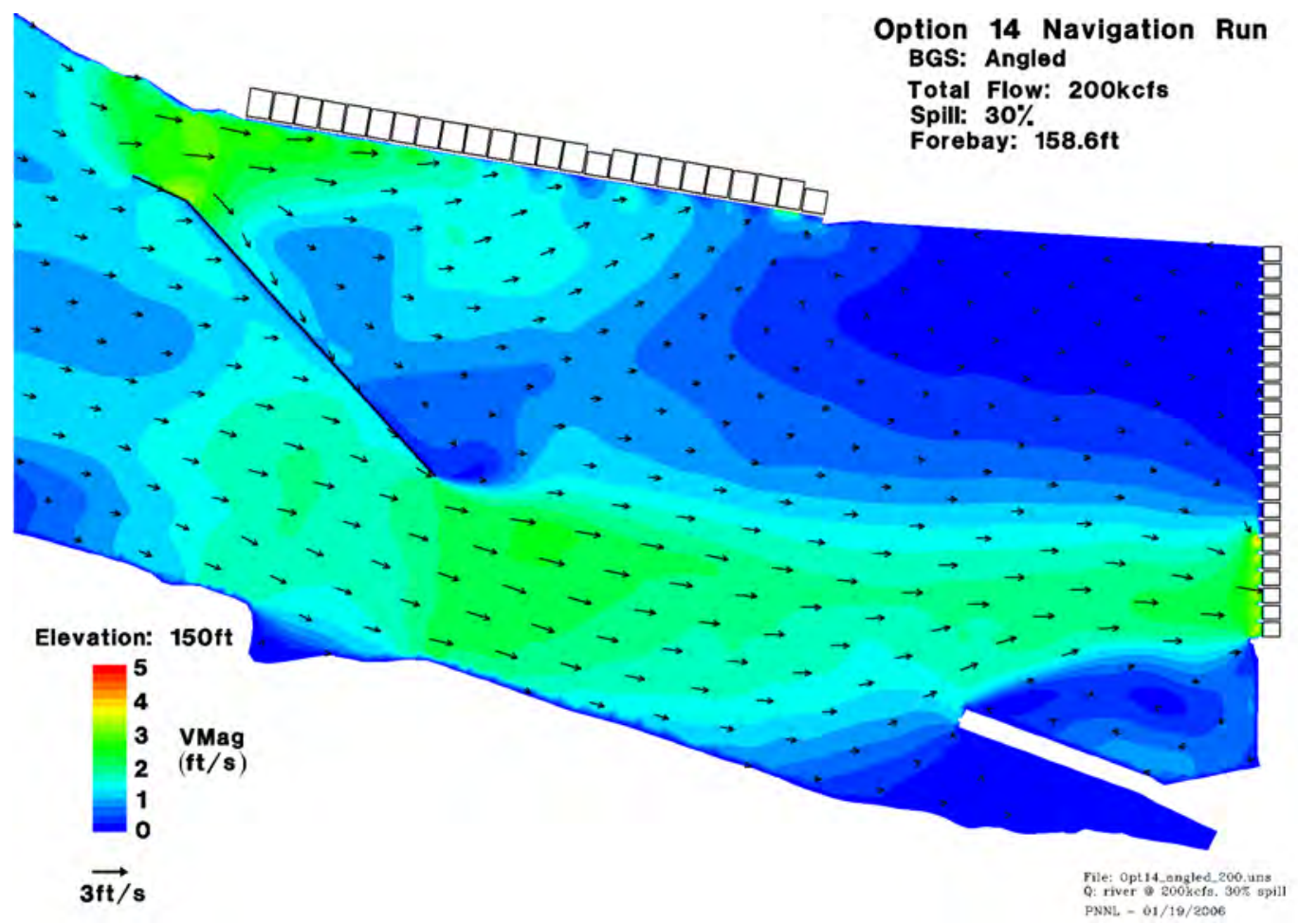

Figure 3.18. Simulation results for a BGS slightly angled at the upstream end for a Total River of $200 \mathrm{kcfs}$ with $30 \%$ spill, at elevation $150 \mathrm{ft}$ 


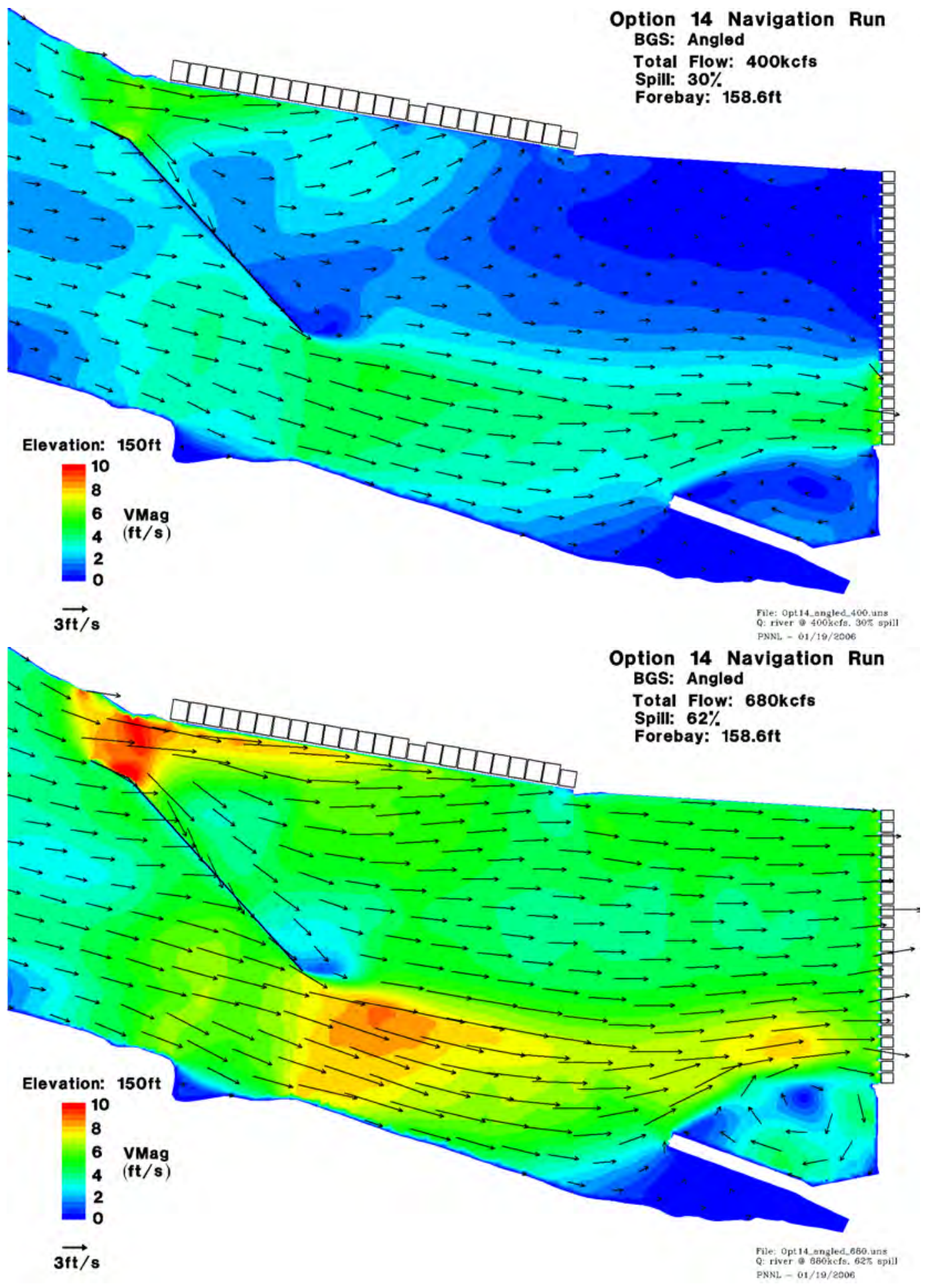

Figure 3.19. Simulation results for a BGS slightly angled at the upstream end for a Total River of $400 \mathrm{kcfs}$ with $30 \%$ spill (top), and $680 \mathrm{kcfs}$ with $62 \%$ spill (bottom) at elevation $150 \mathrm{ft}$ 


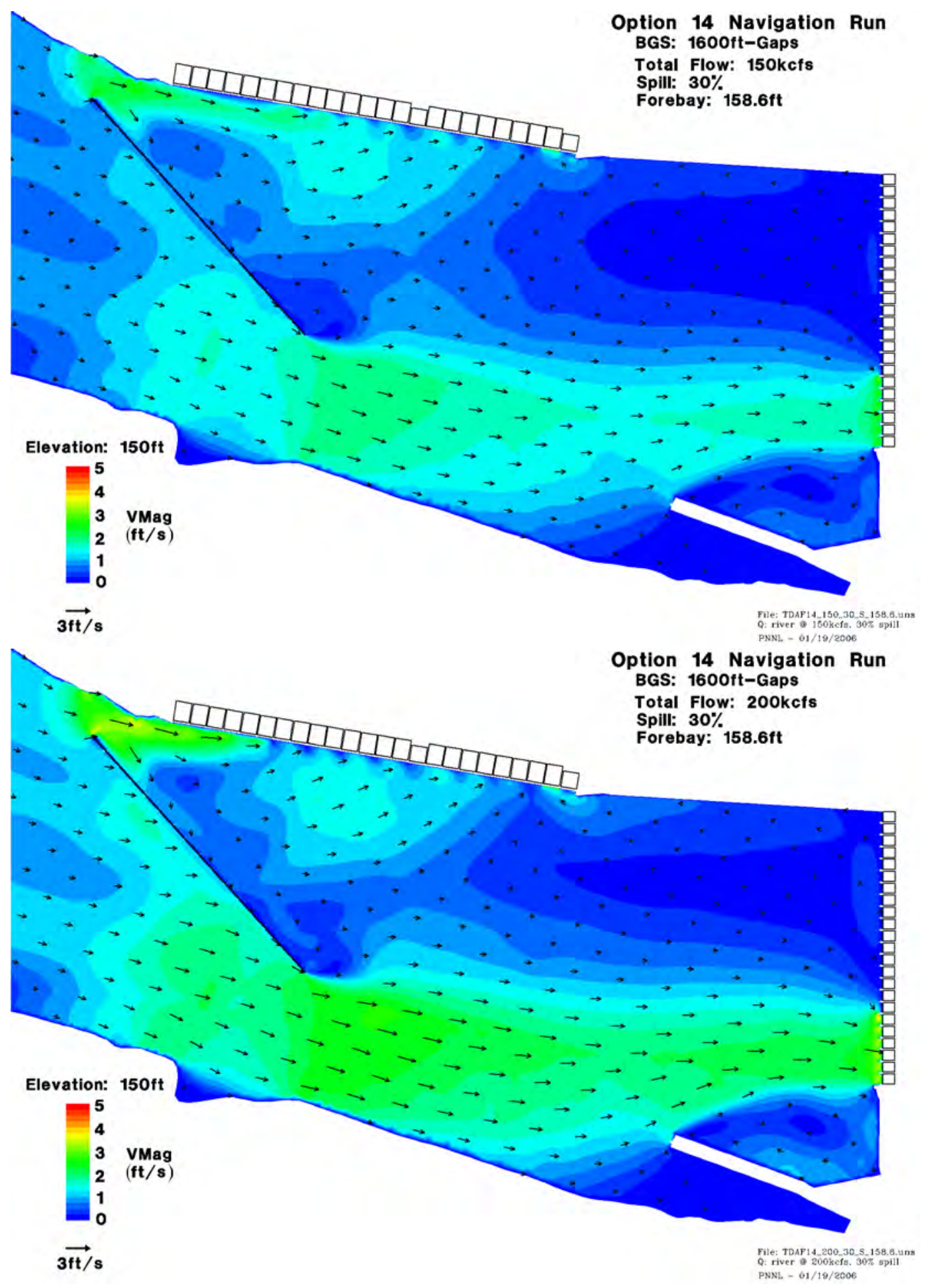

Figure 3.20. Simulation results for a $1600-\mathrm{ft}$ BGS with 2-ft gaps every $100 \mathrm{ft}$ for a Total River of $150 \mathrm{kcfs}$ with $30 \%$ spill (top) and a Total River of $200 \mathrm{kcfs}$ with $30 \%$ spill (bottom) 


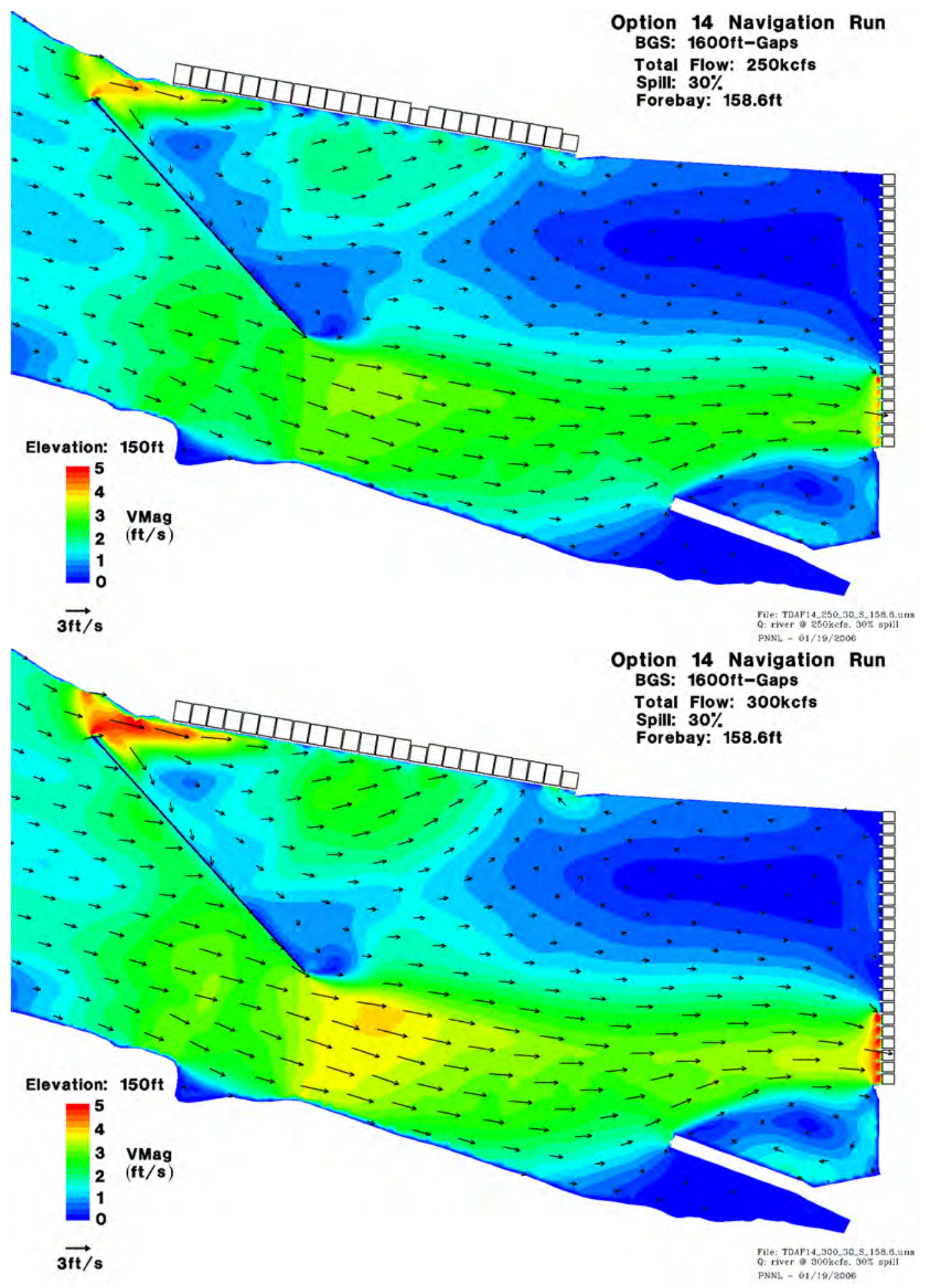

Figure 3.21. Simulation results for a $1600-\mathrm{ft}$ BGS with 2-ft gaps every $100 \mathrm{ft}$ for a Total River of $250 \mathrm{kcfs}$ with $30 \%$ spill (top) and a Total River of $300 \mathrm{kcfs}$ with $30 \%$ spill (bottom) 


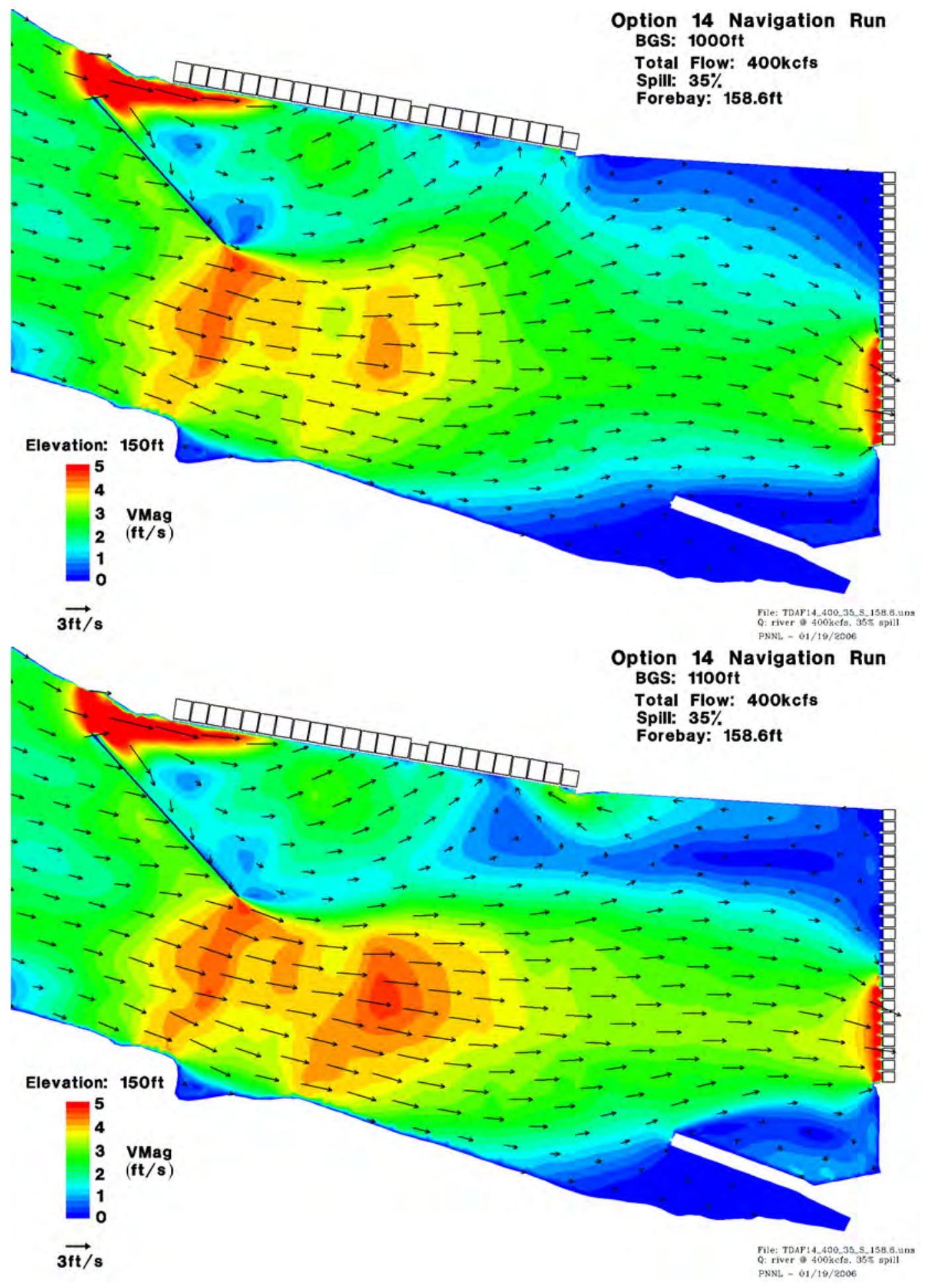

Figure 3.22. Simulation results for a Total River of $400 \mathrm{kcfs}$ with $35 \%$ spill for a 1000 -ft length (top), 1100-ft length (bottom). 


\subsection{Conclusions and Recommendations}

Flow fields in The Dalles forebay were simulated using a 3-D CFD model for a large range of operational scenarios, both for the existing forebay and for five proposed locations of a BGS. The simulation results led to the following conclusions:

- The BGS increased the flow (both the number of streamlines and flow velocities) on the shallow area of the Washington shore relative to the clean forebay. The longer the BGS, the more pronounced the effect.

- The downstream hydraulic impact of the BGS extends into the non-overflow area of the dam and is more pronounced at lower spill percentages. As this zone could be a staging area for predators, the potential biological impacts should be carefully evaluated.

- Flow patterns and velocities are important on both sides of the BGS. The extent of the helical recirculation on the downstream side of the BGS is influenced by the depth and angle of the BGS and the project operations.

- Streamlines for flows that pass under the BGS typically exit the forebay through the powerhouse.

- The location of the downstream end of the BGS is critical. Options 1 and 3 showed that a relatively small change in the location greatly impacts the fate of streamlines that start at the downstream end of the BGS.

- Project operations with $20 \%$ spill produce biologically unacceptable hydraulics in the forebay. Streamlines from the BGS pass through the non-overflow area and exit the forebay through the powerhouse for many scenarios.

- BGS location and length can influence flows to the sluiceway at the powerhouse. Flows moving downstream along the face of the powerhouse can pass the sluice gates. Other flows off the downstream end of the BGS can also intersect the sluiceway.

The determination that the BGS location deemed suitable by the engineers and biologists had negative impacts on navigation leads to the following recommendations for future work:

- A more comprehensive list of constraints for site selection should be developed. Future evaluation metrics need to include velocity criteria for navigation and delineation of areas where it is required that there be little or no impact by the BGS structure. CFD models can be used to identify the most promising locations and to provide quantified metrics for biological, hydraulic, and navigation criteria. The most promising locations should then be further evaluated in the 1:80 general physical model.

- Future fish studies should evaluate surface orientation. The strength of the preference can be incorporated into future CFD and physical model evaluations of the potential effectiveness of a BGS structure, especially its depth below the water surface. 
- Because initial navigation studies point to the need for a much shorter BGS, the potential for enhanced sluiceway passage needs to be investigated. If a much shorter BGS is required to not negatively impact navigation, is it possible to guide fish to the sluiceway entrances rather than the spillway? Again, it is crucial to know if juvenile salmon are strongly surface oriented for this approach to be viable. 


\subsection{References}

ADAPCO CDL. 2004. User Guide, STAR-CD Version 3.20. CD adapco Group, http://www.cdadapco.com.

Cash K, D Faber, T Hatton, E Jones, R Magie, N Swyers, R Burns, M Sholtis, S Zimmerman, J Hughes, T Gilbride, N Adams, and D Rondorf. 2005. Three-dimensional Behavior and Passage of Juvenile Salmonids at The Dalles Dam, 2004. USGS. Final Report by U.S. Geological Survey and Pacific Northwest National Laboratory to U.S. Army Corps of Engineers Portland, Oregon under Contract Number W66QKZ402778562.

ENSR. 2001. Three-Dimensional Computational Fluid Dynamics (CFD) Modeling of the Forebay of The Dalles Dam, Oregon. Final Report Document Number 3697-006-320, ENSR International, INCA Engineers.

Johnson G, M Hanks, J Hedgepeth, B McFadden, R Moursund, R Mueller, and J Skalski. 2003. Hydroacoustic Evaluation of Turbine Intake J-Occlusions at The Dalles Dam in 2002. PNWD3226, Pacific Northwest National Laboratory.

Johnson G, M Hanks, F Khan, C Cook, J Hedgepeth, R Mueller, C Rakowski, M Richmond, S Sargeant, J Serkowski, and J Skalski. 2005a. Hydroacoustic Evaluation of Juvenile Salmonid Passage at The Dalles Dam in 2004. PNNL-15180, Pacific Northwest National Laboratory, Richland, Washington.

Johnson G, F Khan, J Hedgepeth, R Mueller, C Rakowski, M Richmond, J Serkowski, and J Skalski. 2005b. Hydroacoustic Evaluation of Juvenile Salmonid Passage at The Dalles Dam Sluiceway, 2005. PNNL-15540, Pacific Northwest National Laboratory, Richland, Washington.

Mannheim C and C Sweeney. 2003. Acoustic Doppler Current Profiler and Point Velocity Measurement Field Data Collection Lower Columbia River Projects. ENSR International. Final Report to the U.S. Army Corps of Engineers, Portland District, Oregon under Contract Number DACW57-02-D-0001.

Ploskey G, T Poe, A Giorgi, and G Johnson. 2001. Synthesis of Radio Telemetry, Hydroacoustic, and Survival Studies of Juvenile Salmon at The Dalles Dam (1982 - 2000). Pacific Northwest National Laboratory, Richland, Washington. http://www.nwp.usace.army.mil/pm/e/reports/afep/tda/ SynthesisofRadioTelemetryHydroacousticandSurvivalStudiesofJuvenileSalmonatTheDallesDam19822000.pdf.

Rakowski C, J Serkowski, M Richmond, and K Recknagle. 2000. Development and Application of a 3D CFD Model for the Bonneville Project Powerhouse 1 and Powerhouse 2. PNNL-13593, Pacific Northwest National Laboratory, Richland, Washington. Prepared for the U.S. Army Corps of Engineers, Portland District. 

Appendix A

\section{Preliminary Results}



Appendix A - Preliminary Results

A. 1 


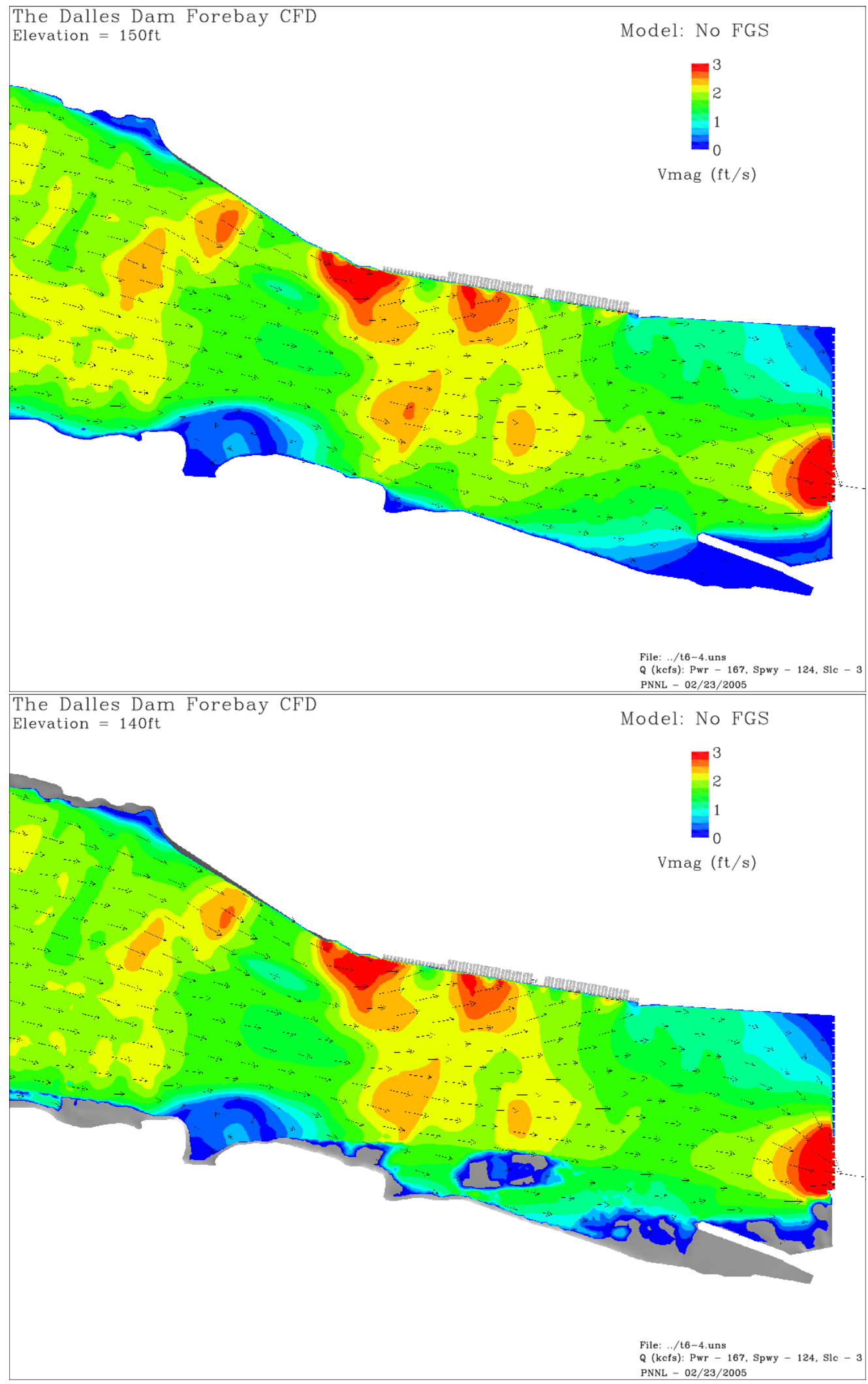

Figure A.1. Clean forebay vectors, elevation $150 \mathrm{ft}$ (top) and $140 \mathrm{ft}$ (bottom). 


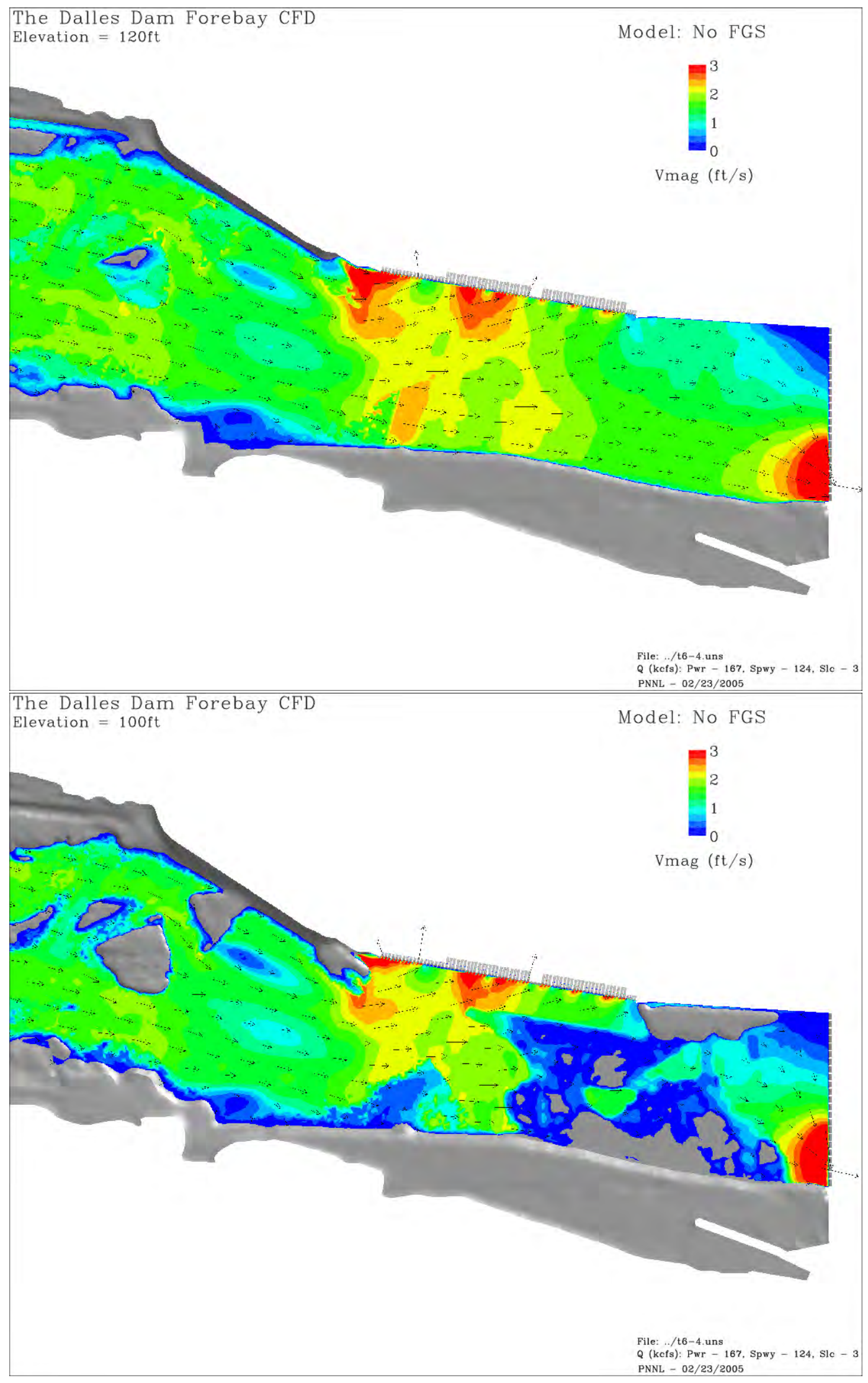

Figure A.2. Clean forebay vectors, elevation $120 \mathrm{ft}$ (top) and $110 \mathrm{ft}$ (bottom). 


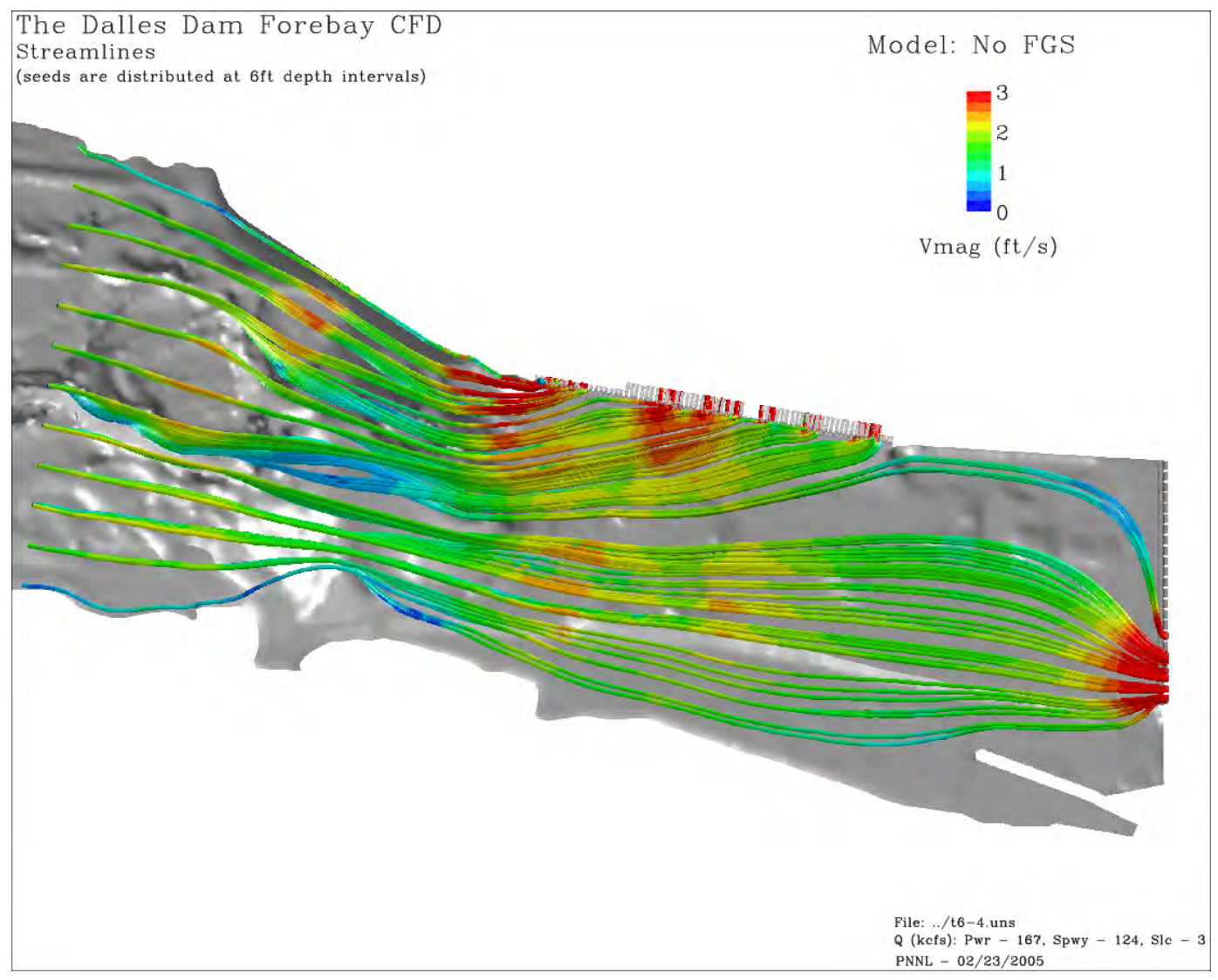

Figure A.3. Clean forebay streamlines. 


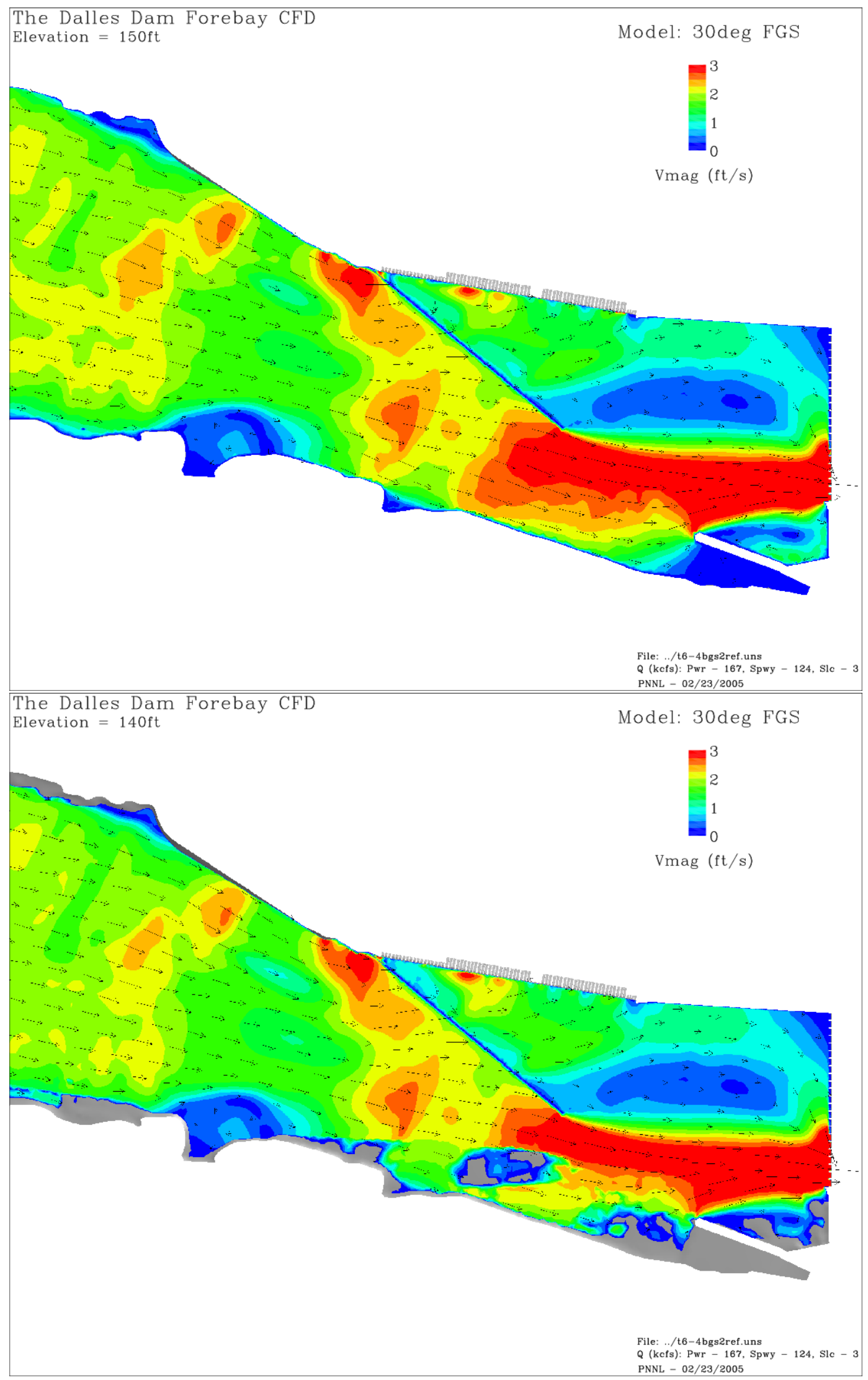

Figure A.4. Velocity vectors for a structure 30 degrees from the powerhouse, elevation $150 \mathrm{ft}$ (top) and $140 \mathrm{ft}$ (bottom). 


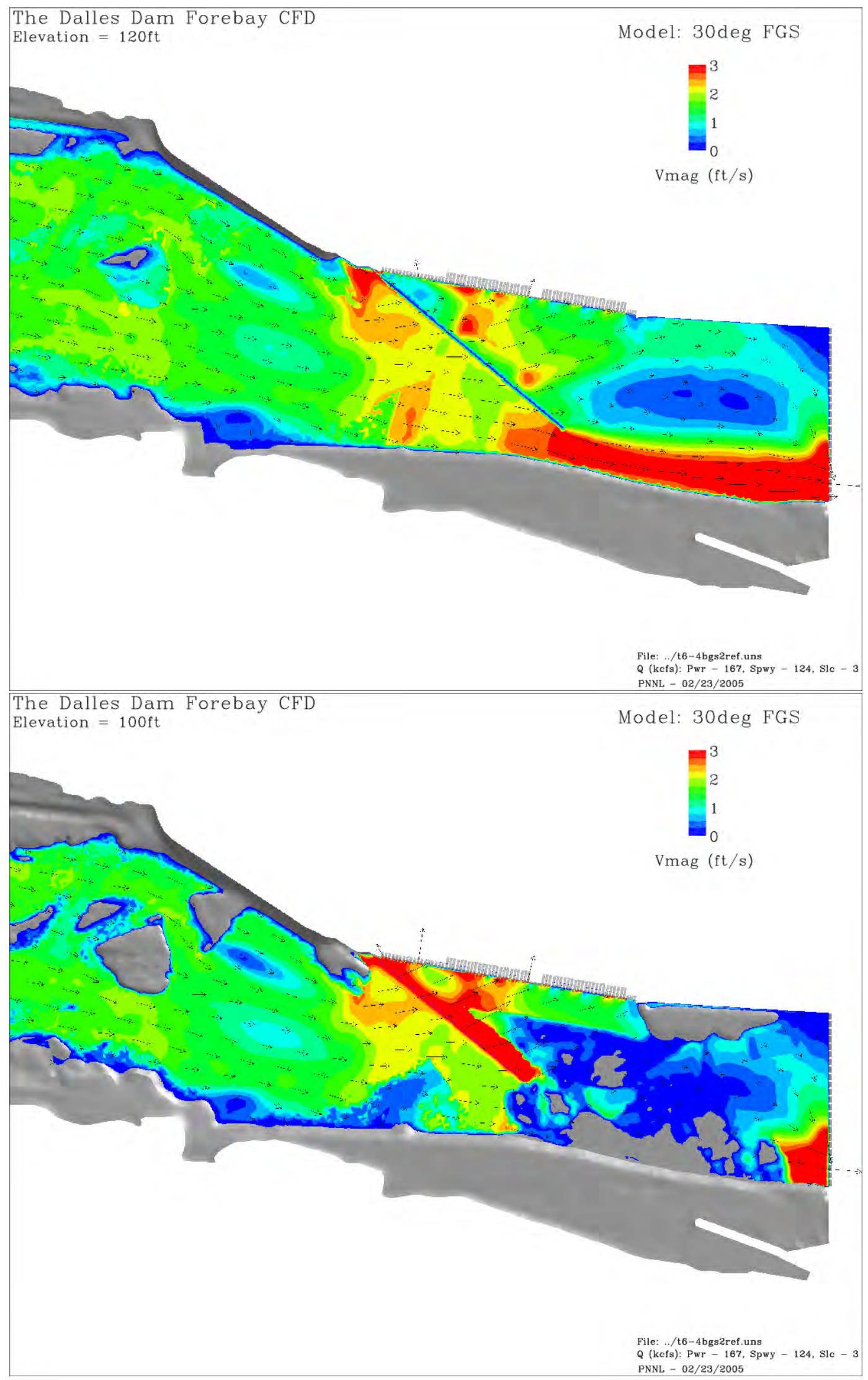

Figure A.5. Velocity vectors for a structure 30 degrees from the powerhouse, elevation $120 \mathrm{ft}$ (top) and $110 \mathrm{ft}$ (bottom). 


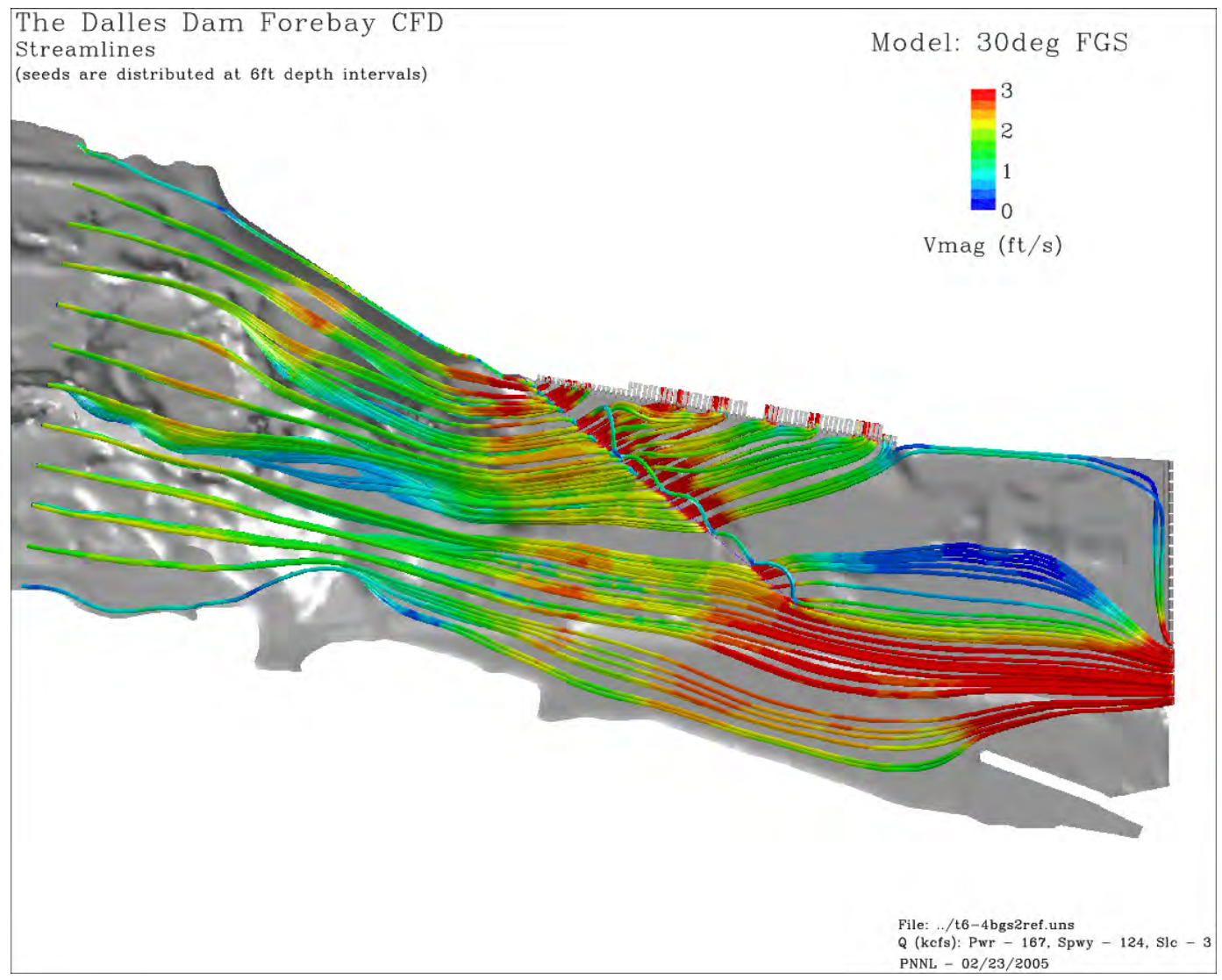

Figure A.6. Streamlines for a structure 30 degrees from the powerhouse. 


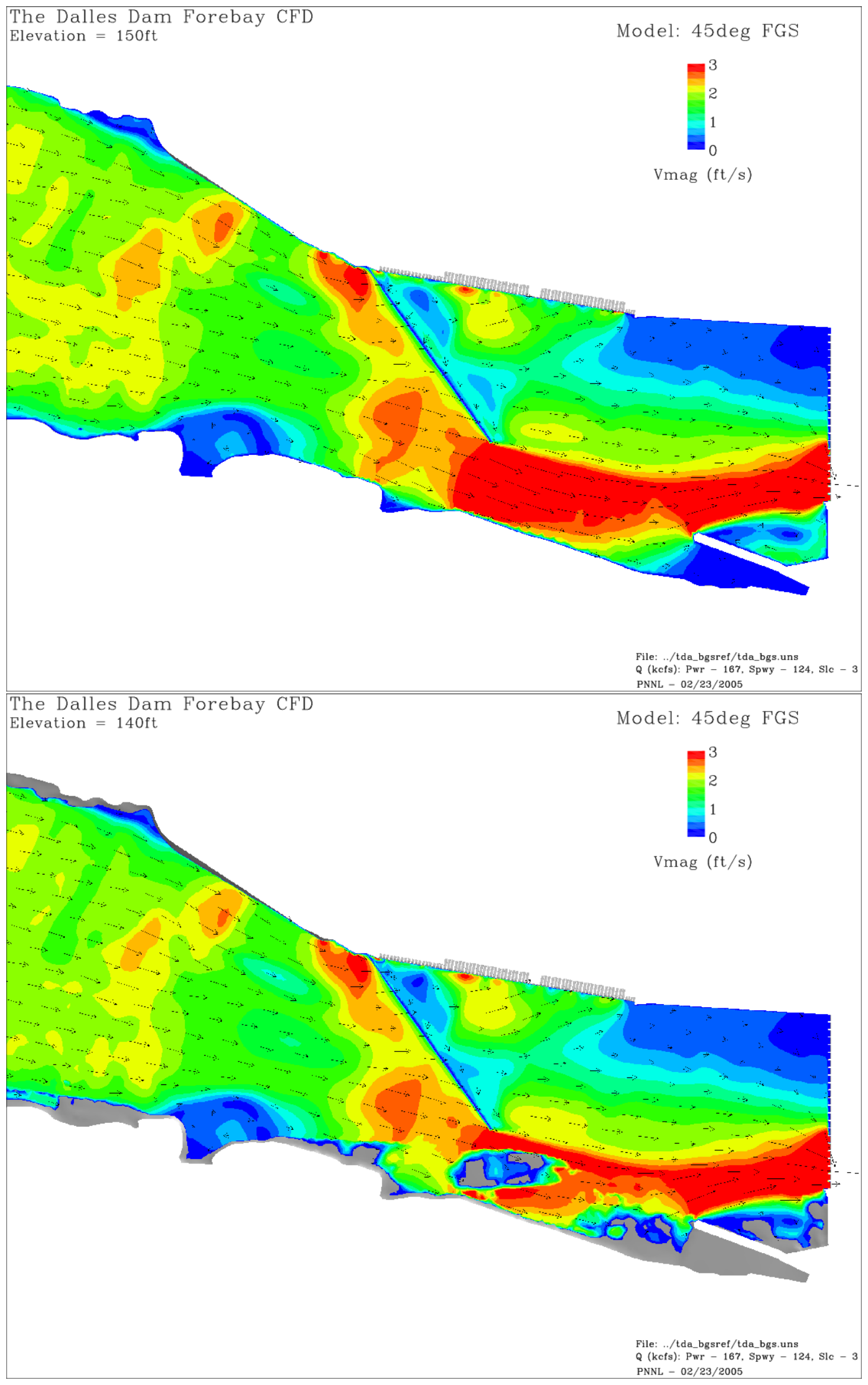

Figure A.7. Velocity vectors for a structure 30 degrees from the powerhouse, elevation $150 \mathrm{ft}$ (top) and $140 \mathrm{ft}$ (bottom). 


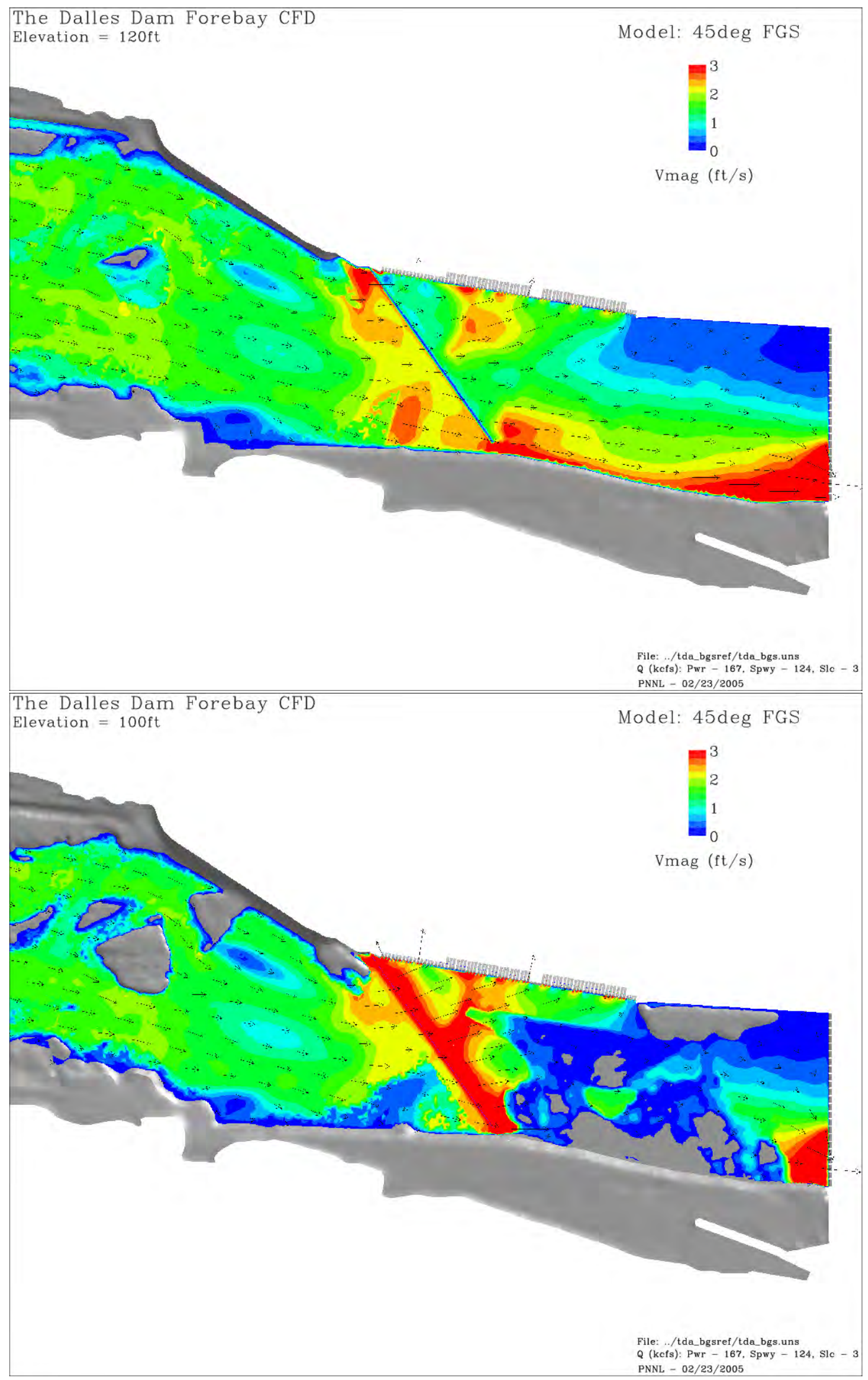

Figure A.8. Velocity vectors for a structure 30 degrees from the powerhouse, elevation $120 \mathrm{ft}$ (top) and $110 \mathrm{ft}$ (bottom). 


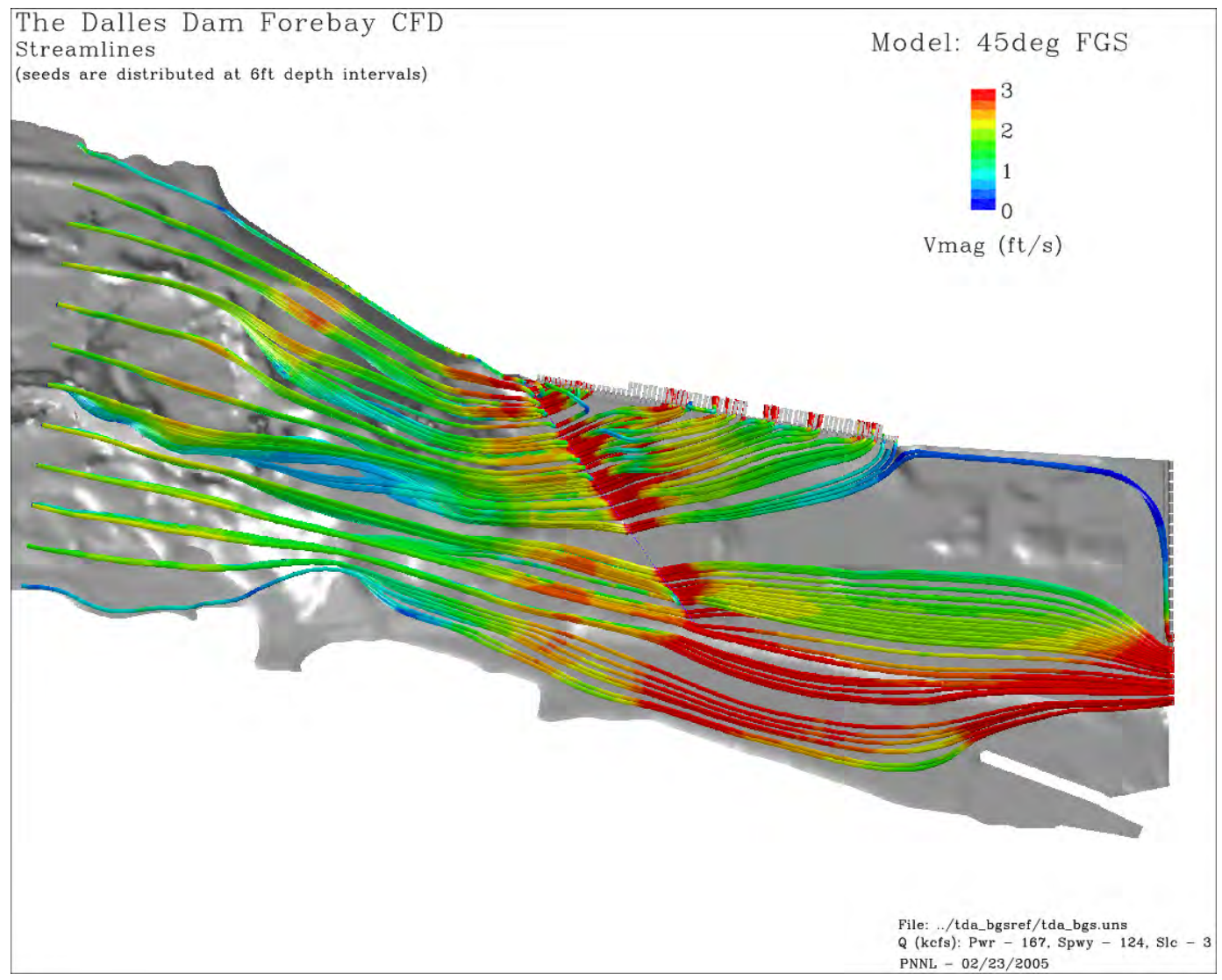

Figure A.9. Streamlines for a structure 30 degrees from the powerhouse. 
Appendix B

\section{BGS Figures for Options 1 to 5}





\section{Appendix B - BGS Figures for Options 1 to 5}

\section{B.1 Reverse Streamline Tracking}

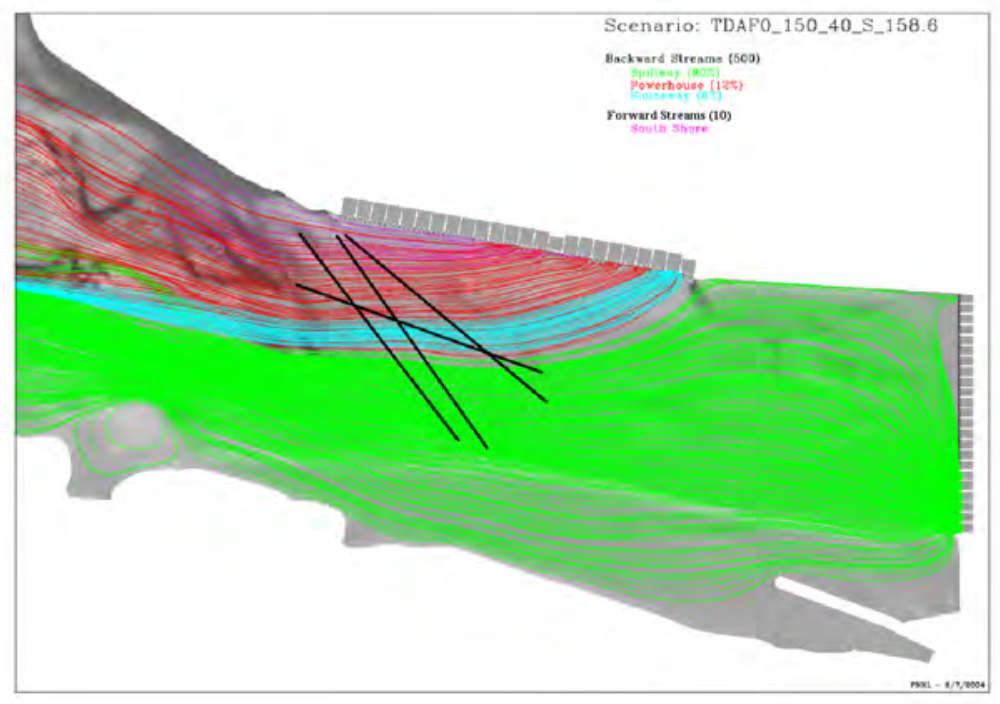

Figure B.1. Comparison for Option 14 Total River $150 \mathrm{kcfs} 40 \%$ spill, standard powerhouse loading to the clean forebay.

B. 1 


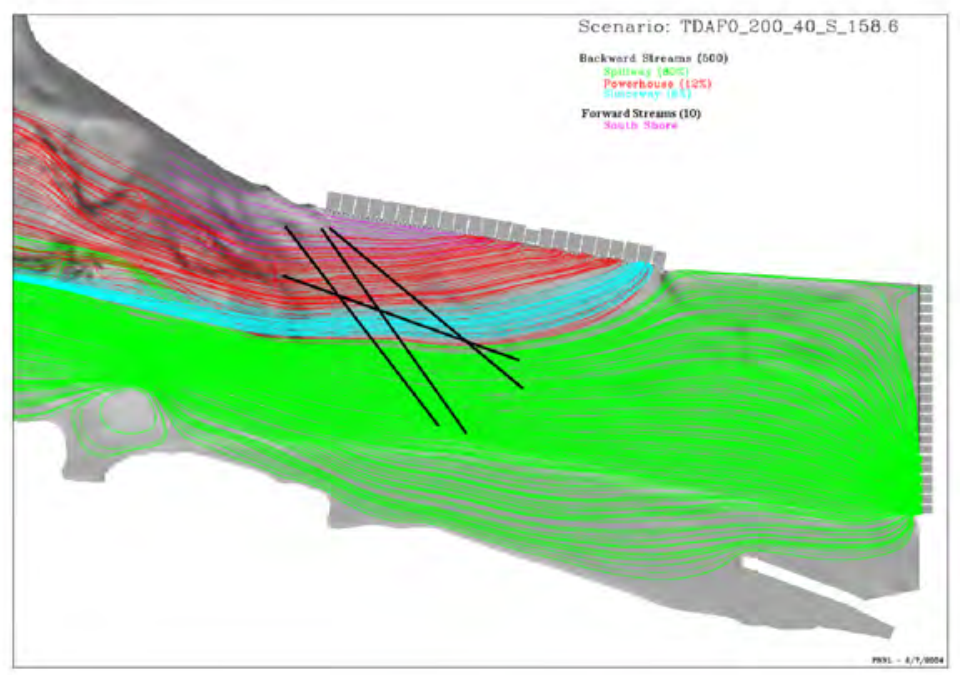

Figure B.2. Comparison for Option 14 Total River $200 \mathrm{kcfs} 40 \%$ spill, standard powerhouse loading to the clean forebay.

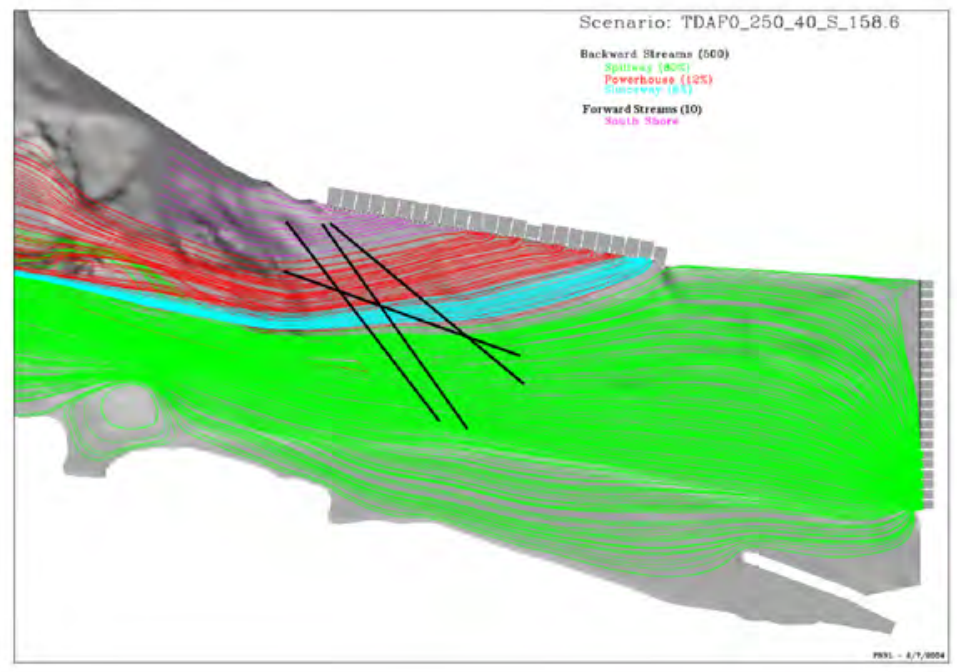

Figure B.3. Comparison for Option 14 Total River $250 \mathrm{kcfs} 40 \%$ spill, standard powerhouse loading to the clean forebay. 


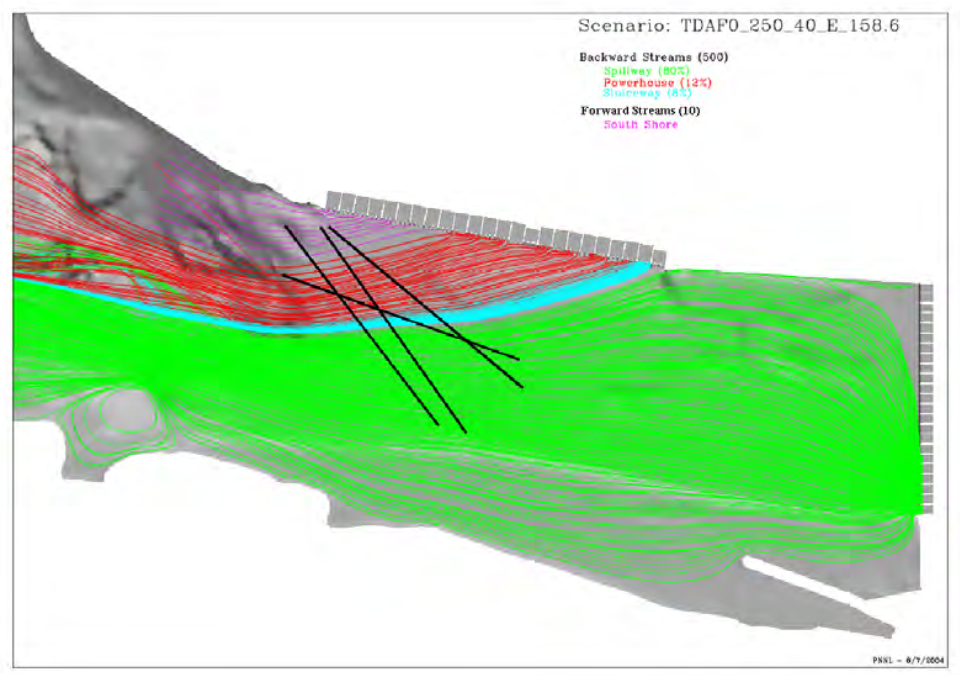

Figure B.4. Comparison for Option 14 Total River $250 \mathrm{kcfs} 40 \%$ spill, standard powerhouse loading to the clean forebay.

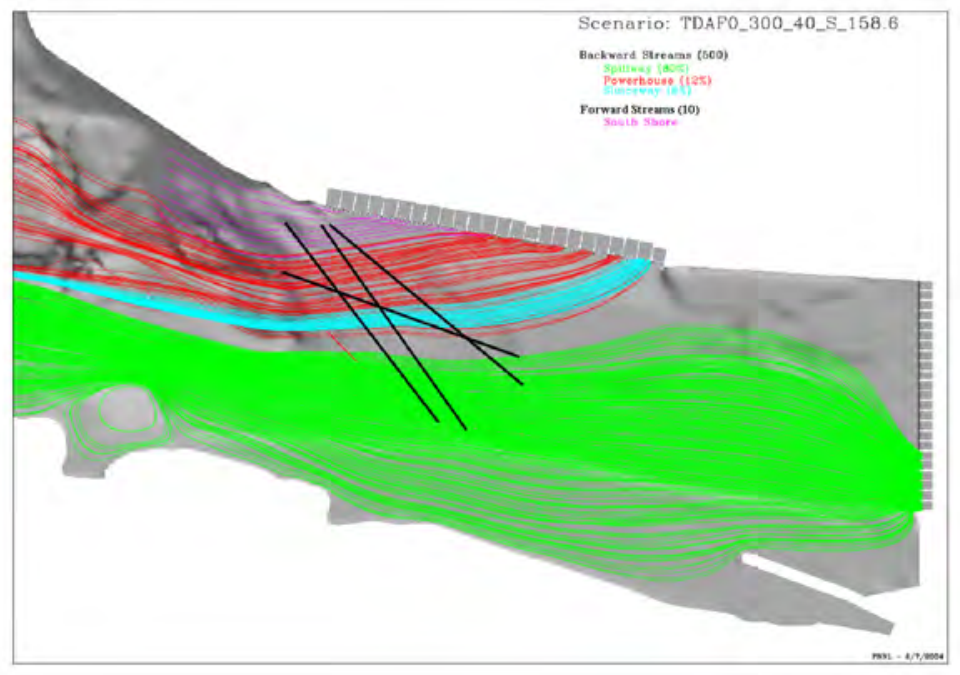

Figure B.5. Comparison for Option 14 Total River $300 \mathrm{kcfs} 40 \%$ spill, standard powerhouse loading to the clean forebay. 


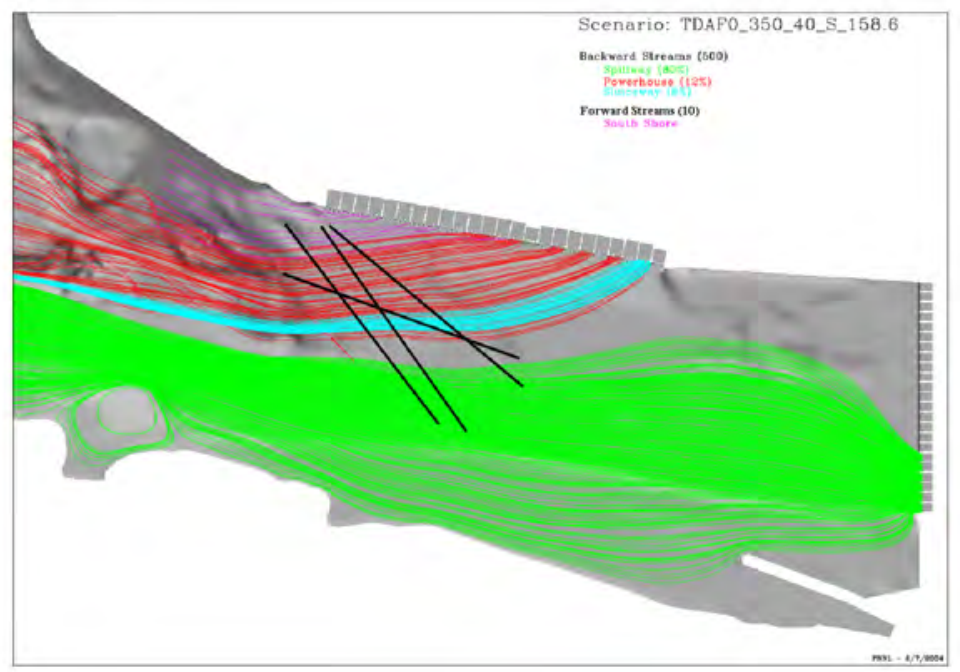

Figure B.6. Comparison for Option 14 Total River $350 \mathrm{kcfs} 40 \%$ spill, standard powerhouse loading to the clean forebay. 


\section{B.2 Scenario Comparisons}

These graphics were provided to USACE CENWP and Agency personnel as 11x17 plates for use in conjunction with ERDC physical model during the June 2005 trip. The graphics were intended help to address the biological metrics and give insight into the potential impacts of a BGS structure in The Dalles Forebay. 


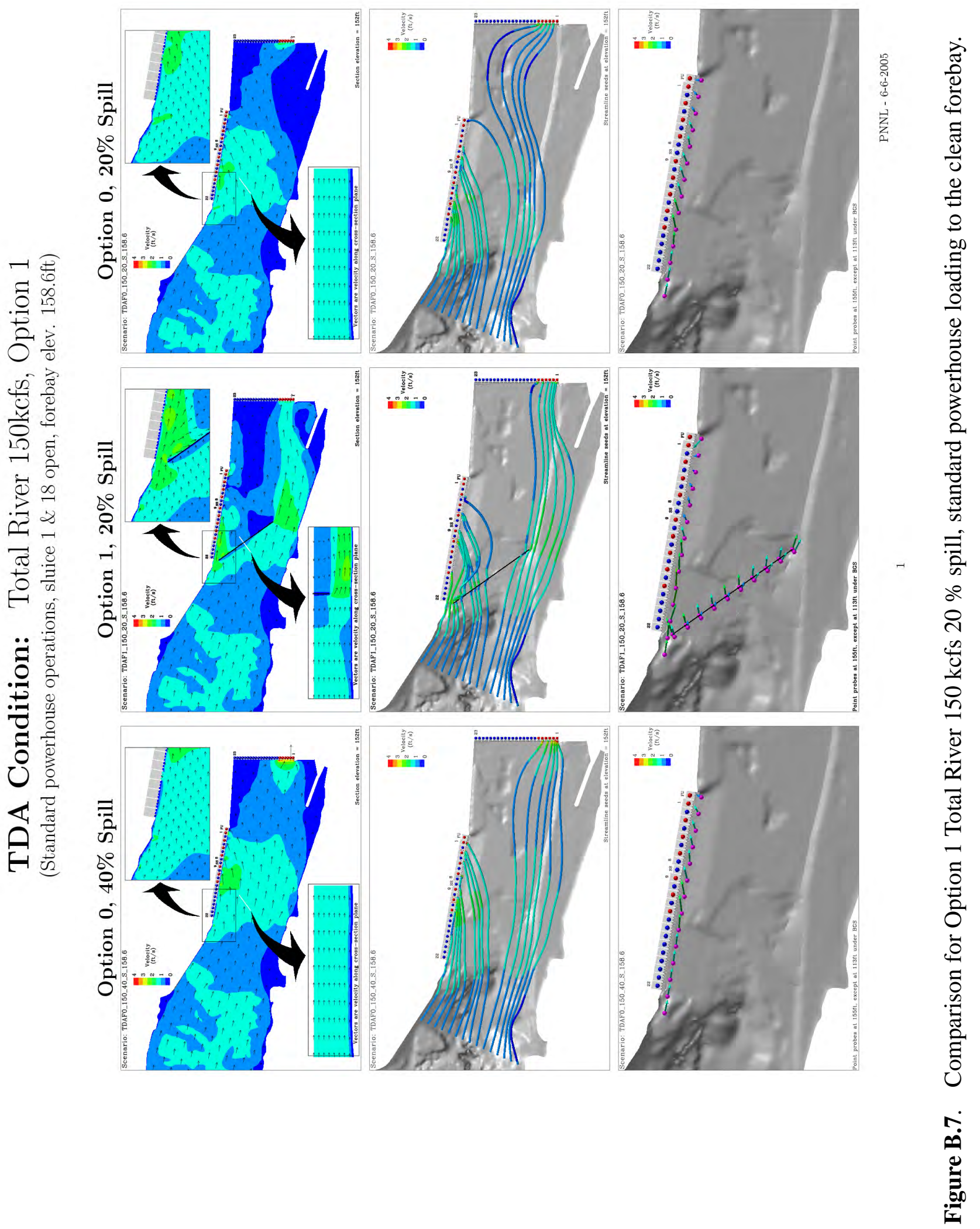




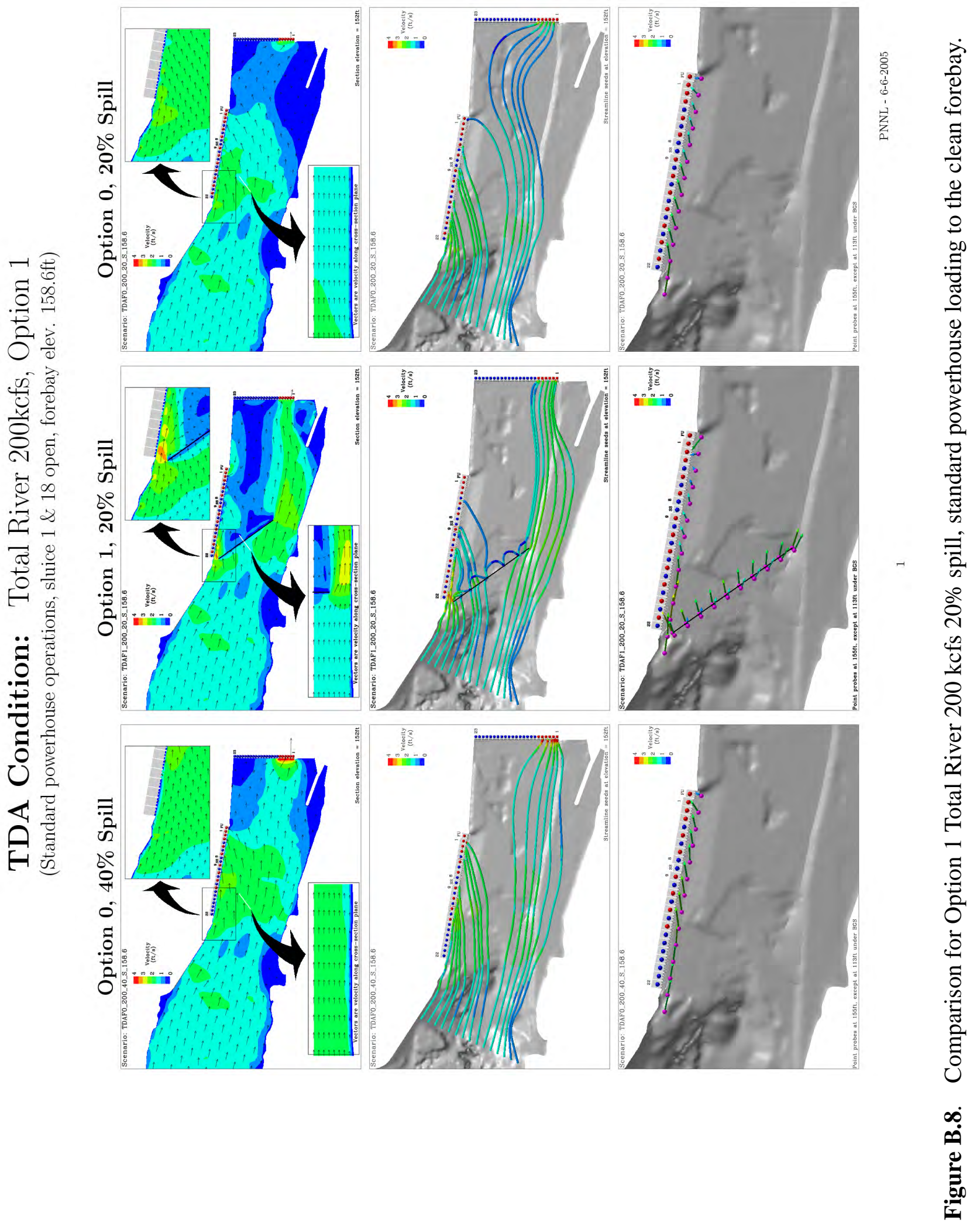

B. 7 


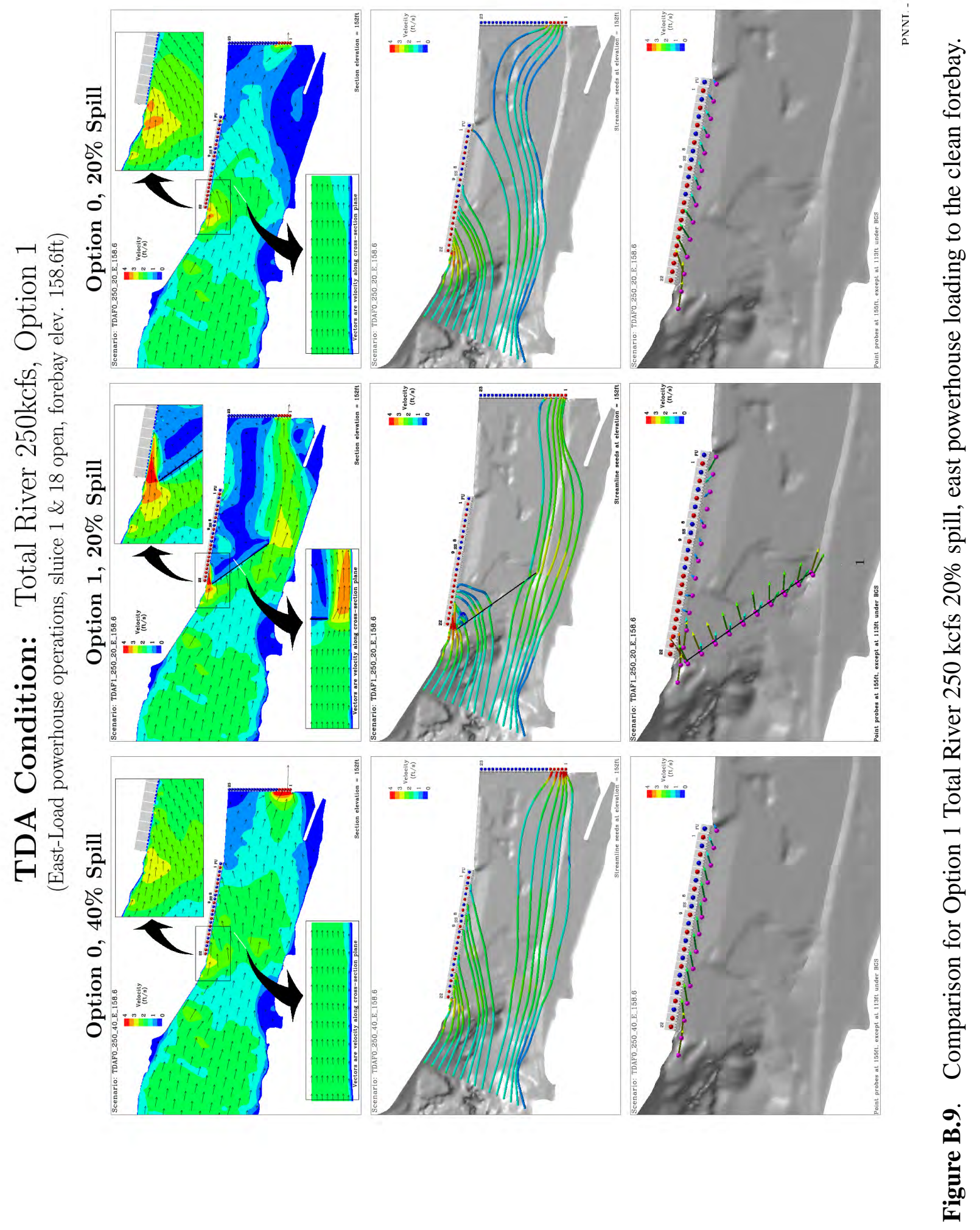




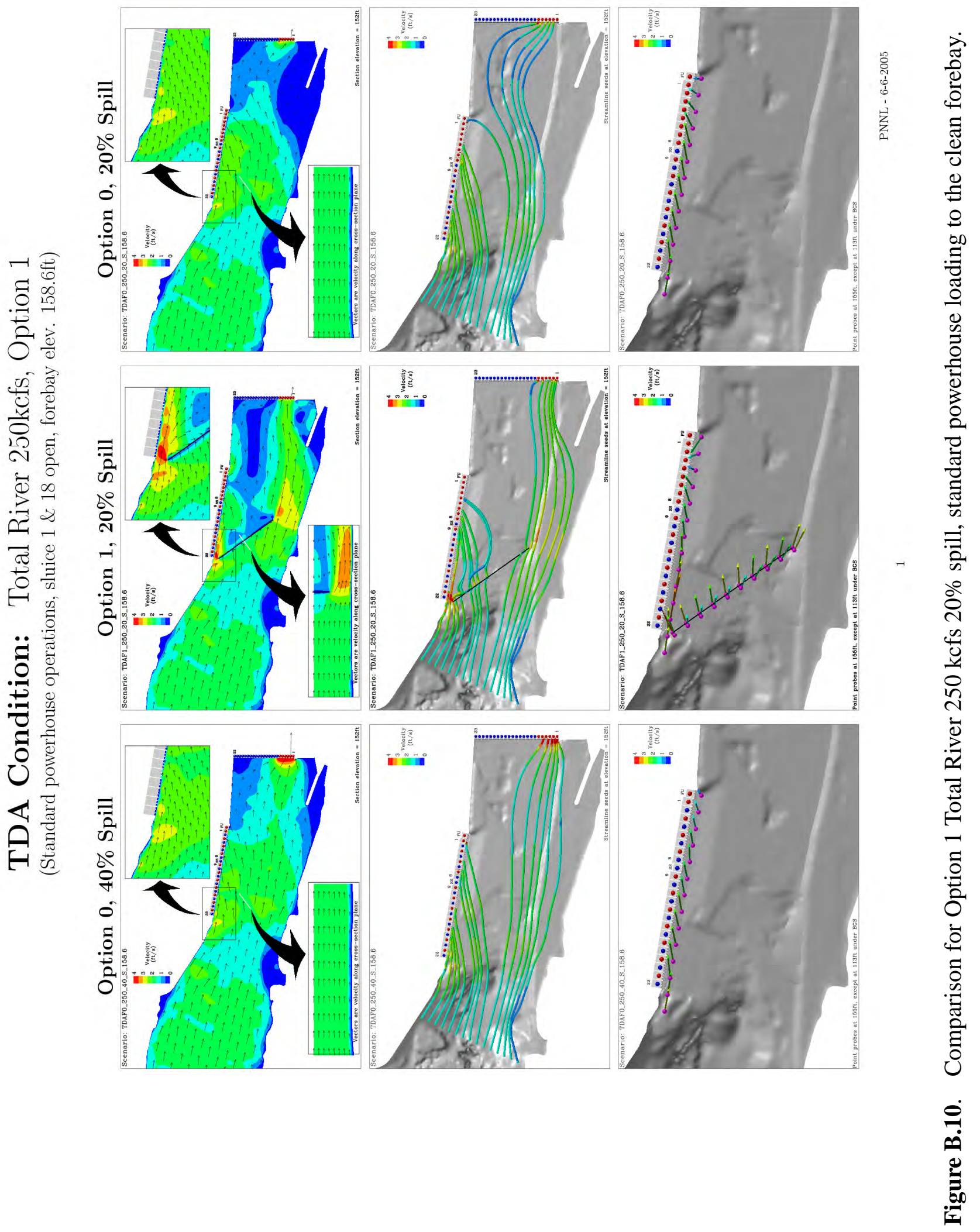



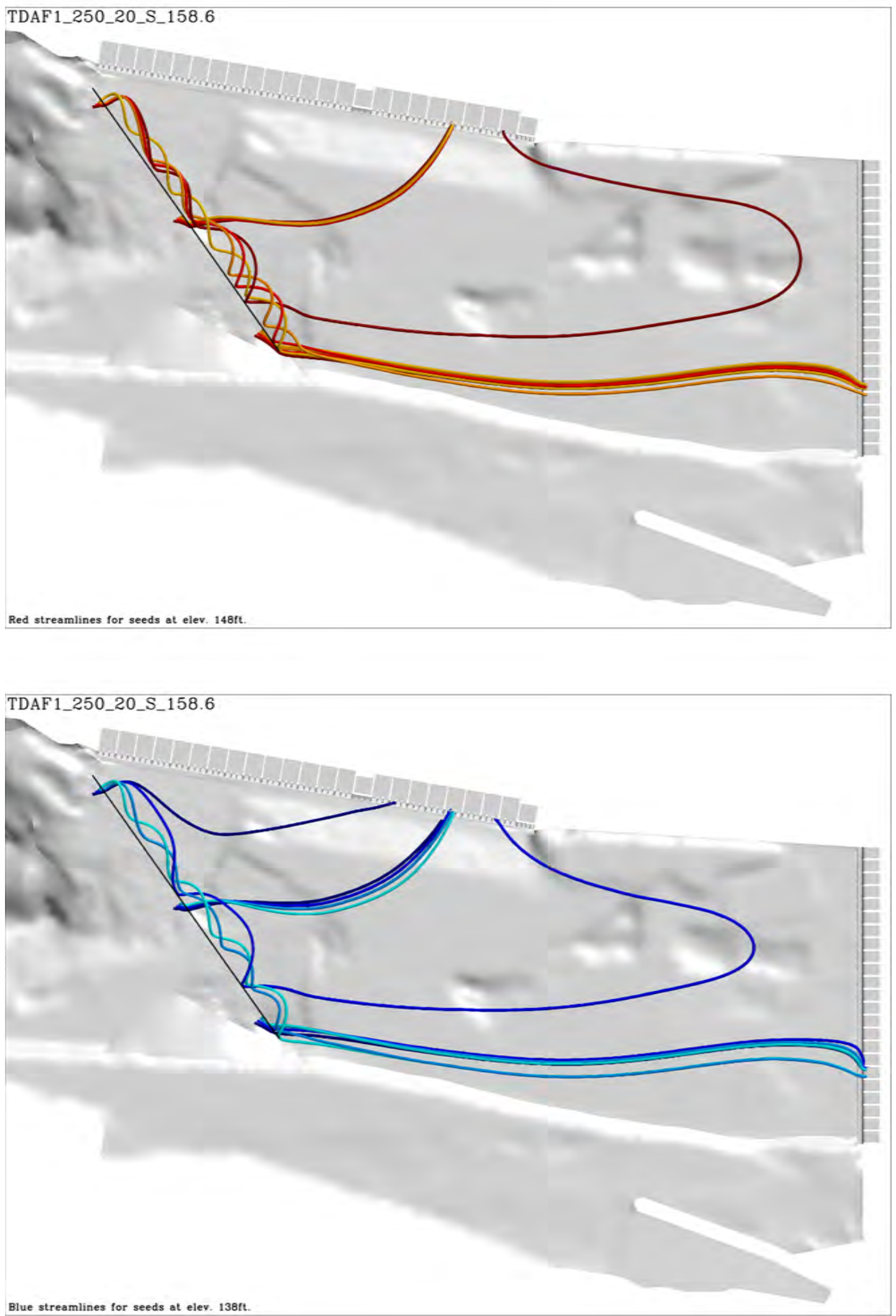

Figure B.11. Option 1 streamlines for Total River $250 \mathrm{kcfs} 20 \%$ spill, standard powerhouse loading at elevation $148 \mathrm{ft}$ (top) and $138 \mathrm{ft}$ (bottom).

B. 10 


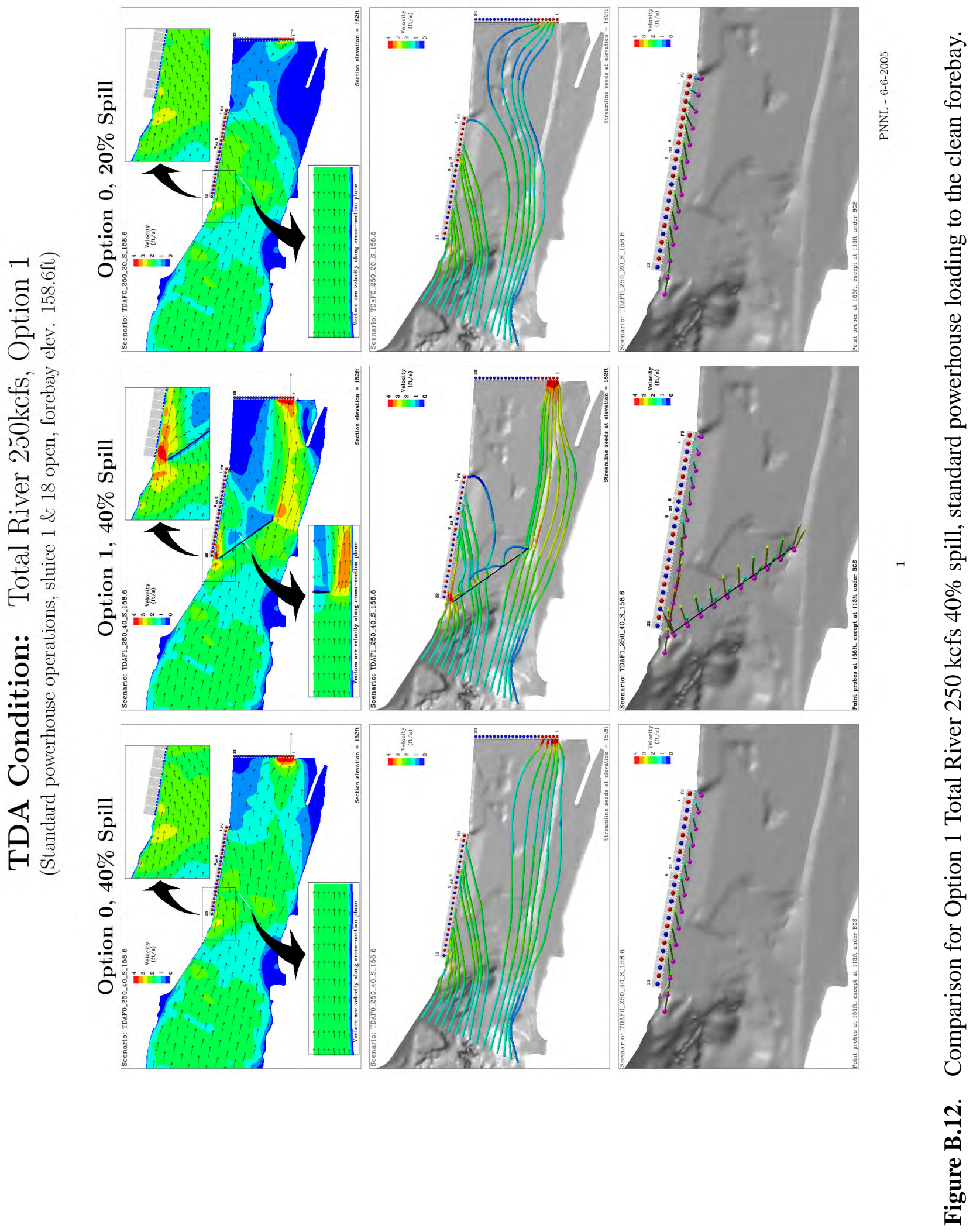




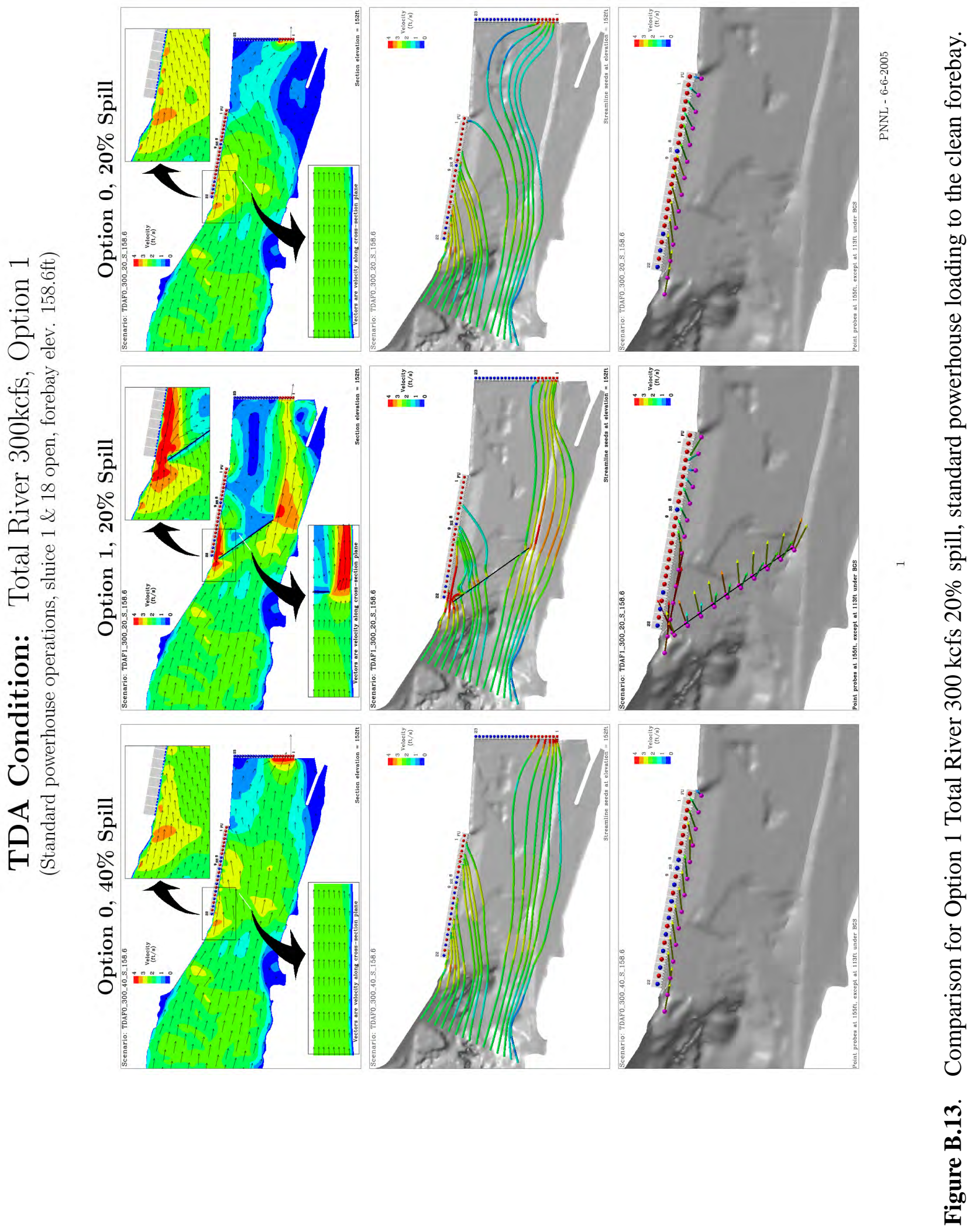




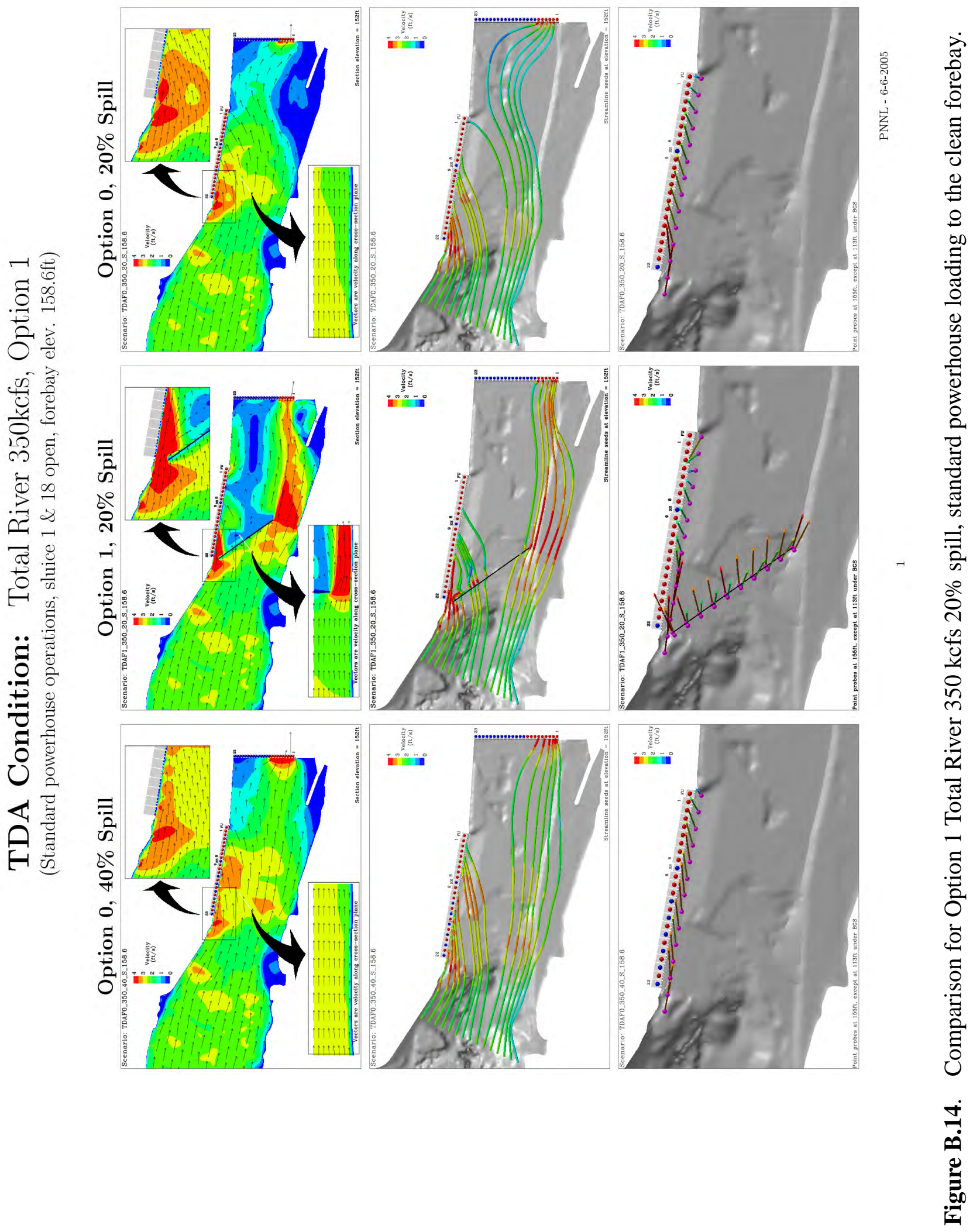




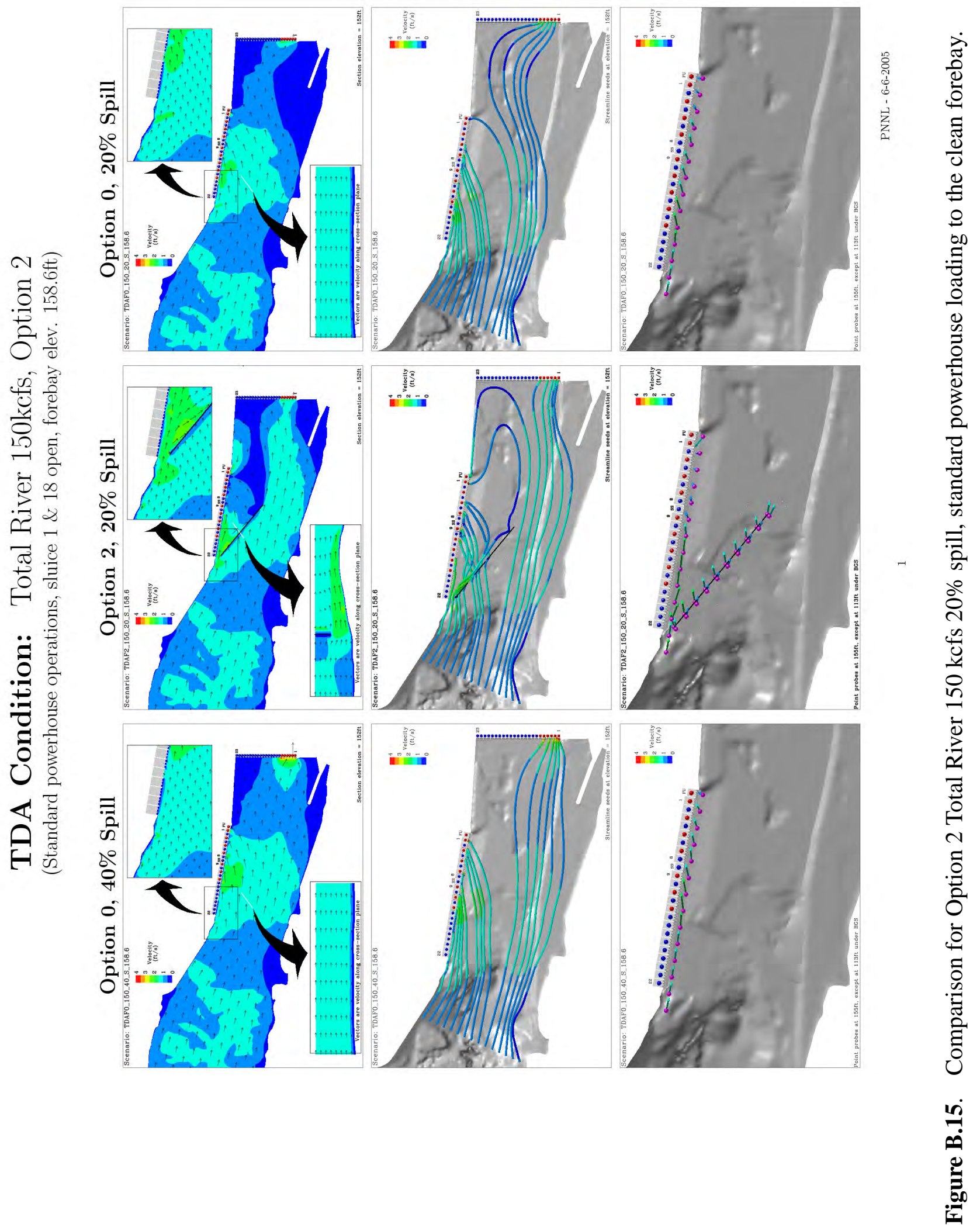




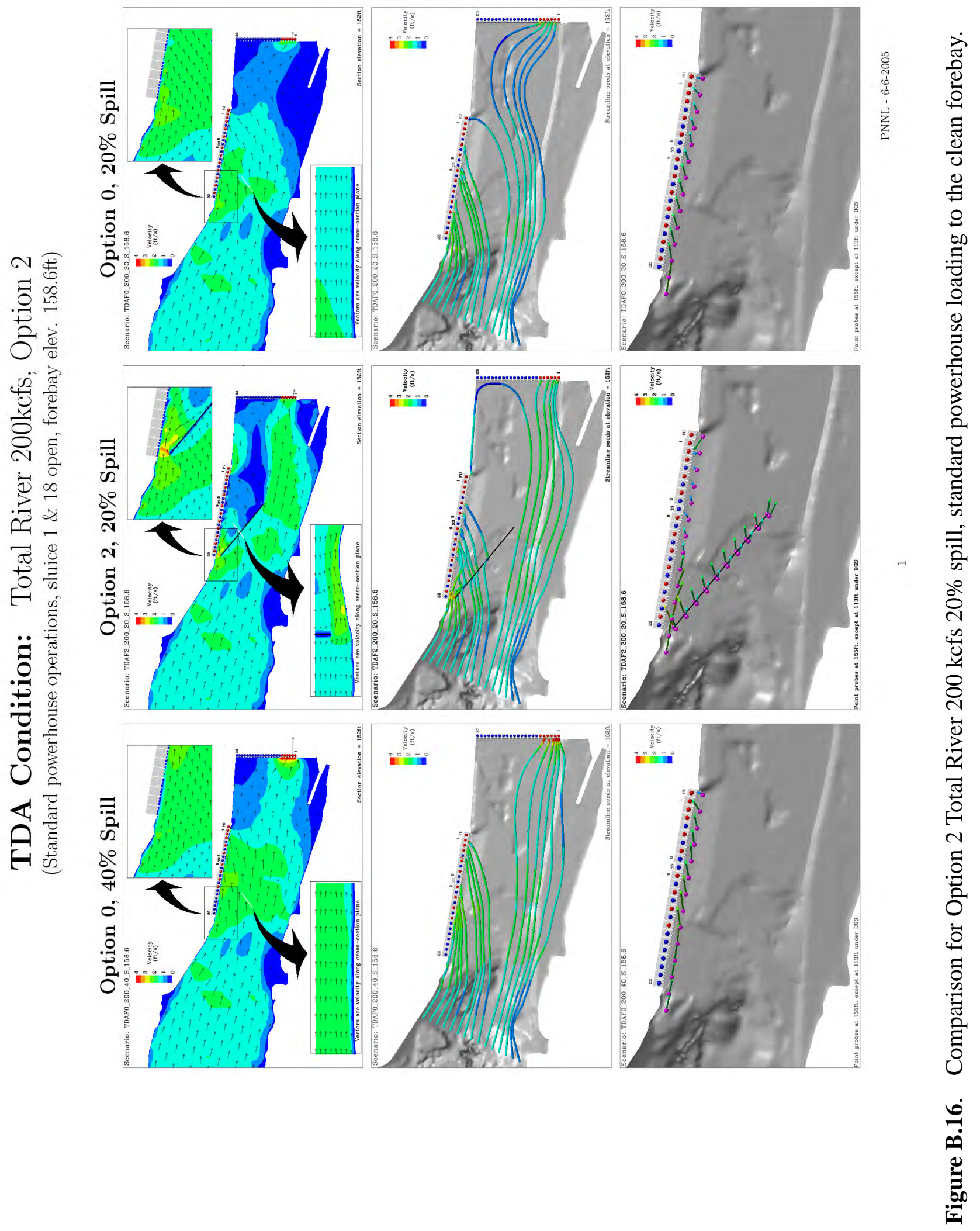




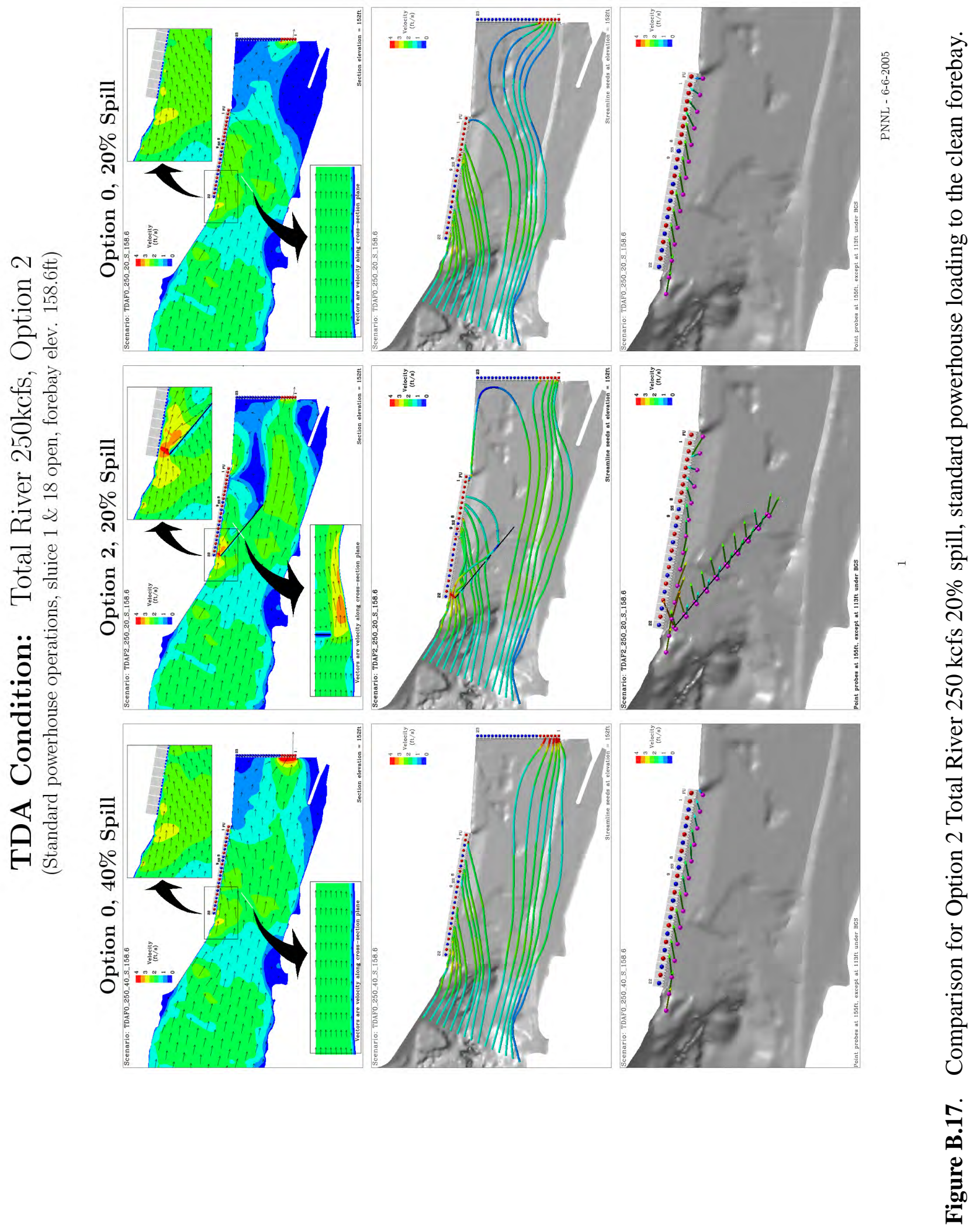



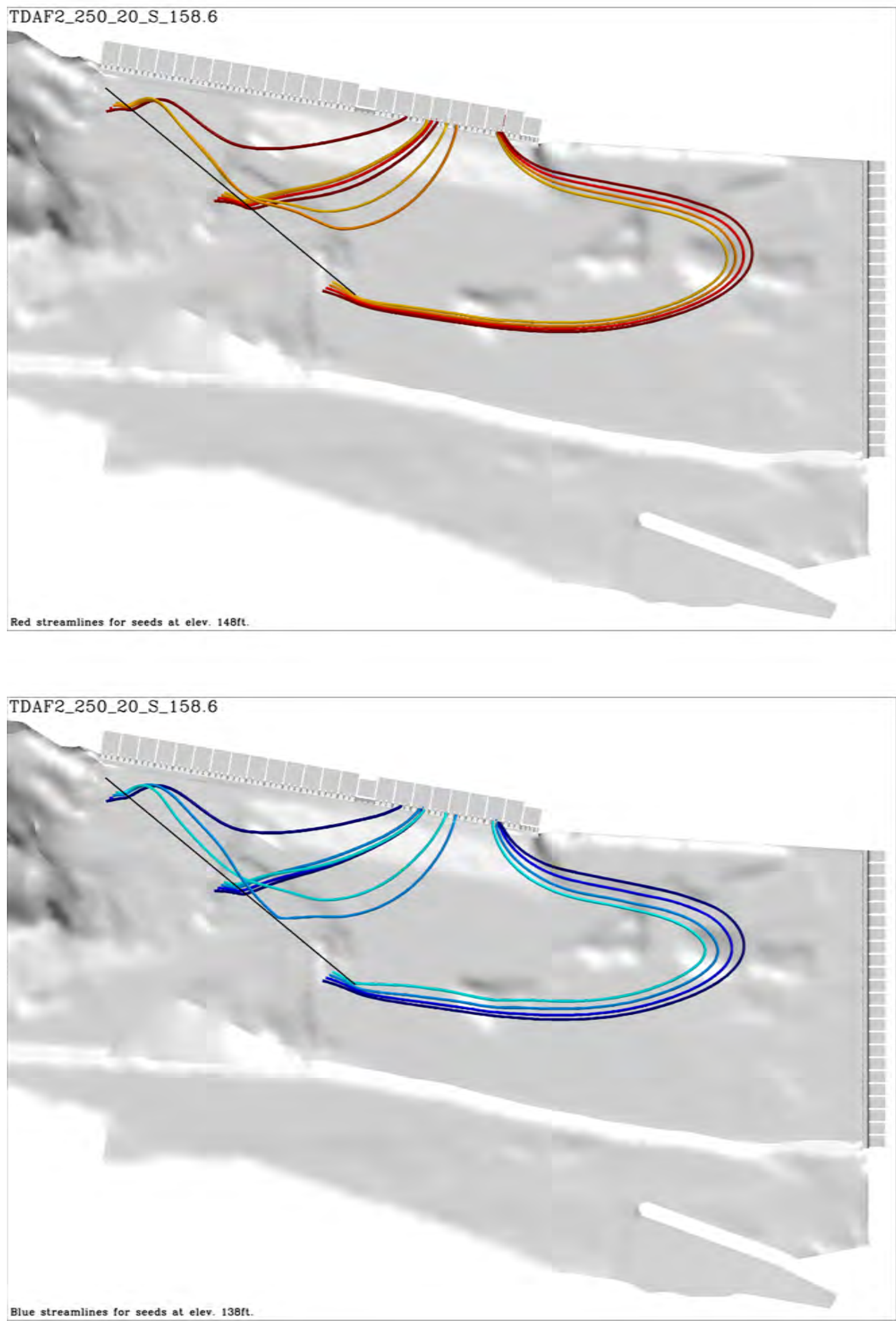

Figure B.18. Option 2 streamlines for particles released near the BGS at elevation $138 \mathrm{ft}$. Total River $250 \mathrm{kcfs} 20 \%$ spill, standard powerhouse loading.

B. 17 


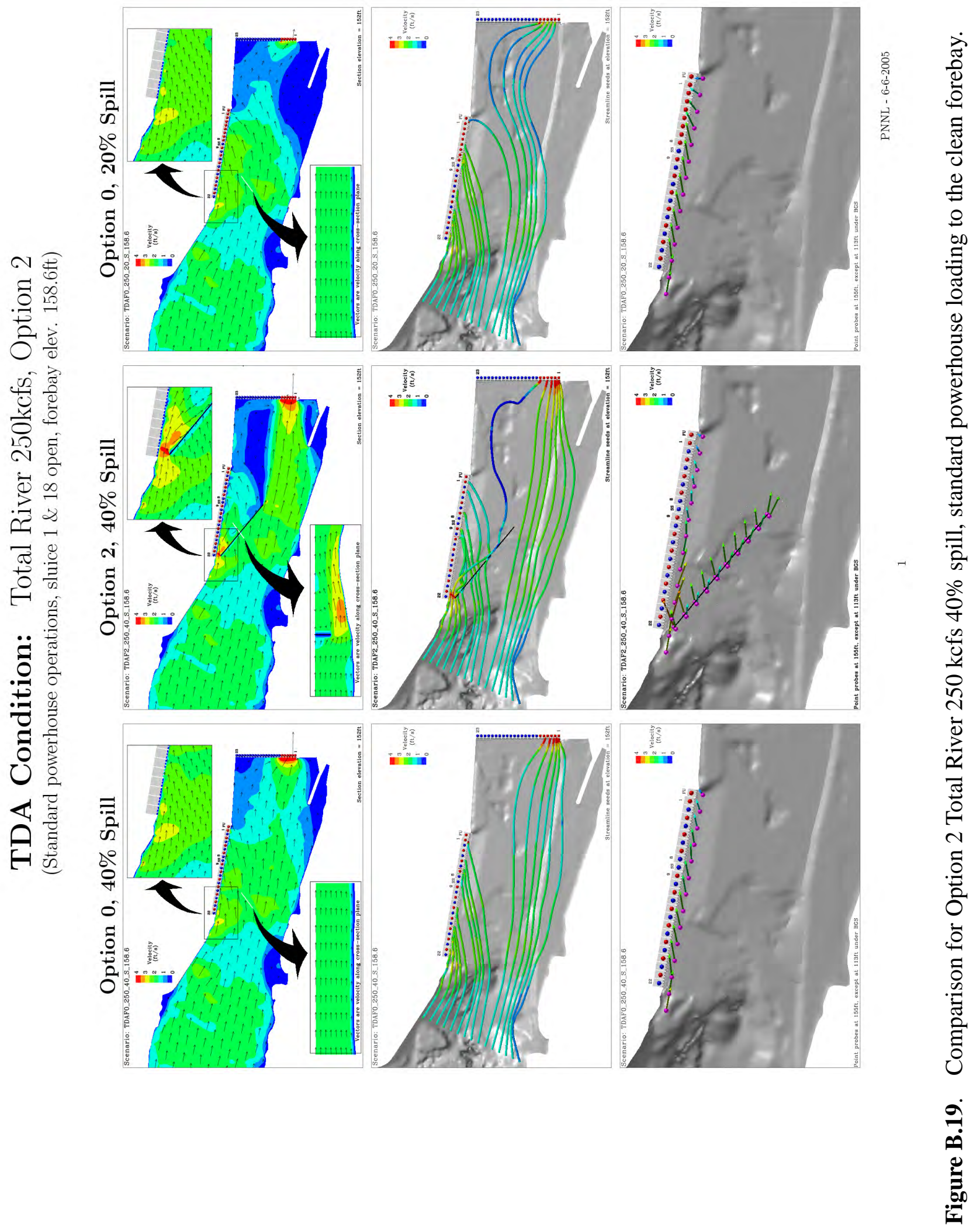




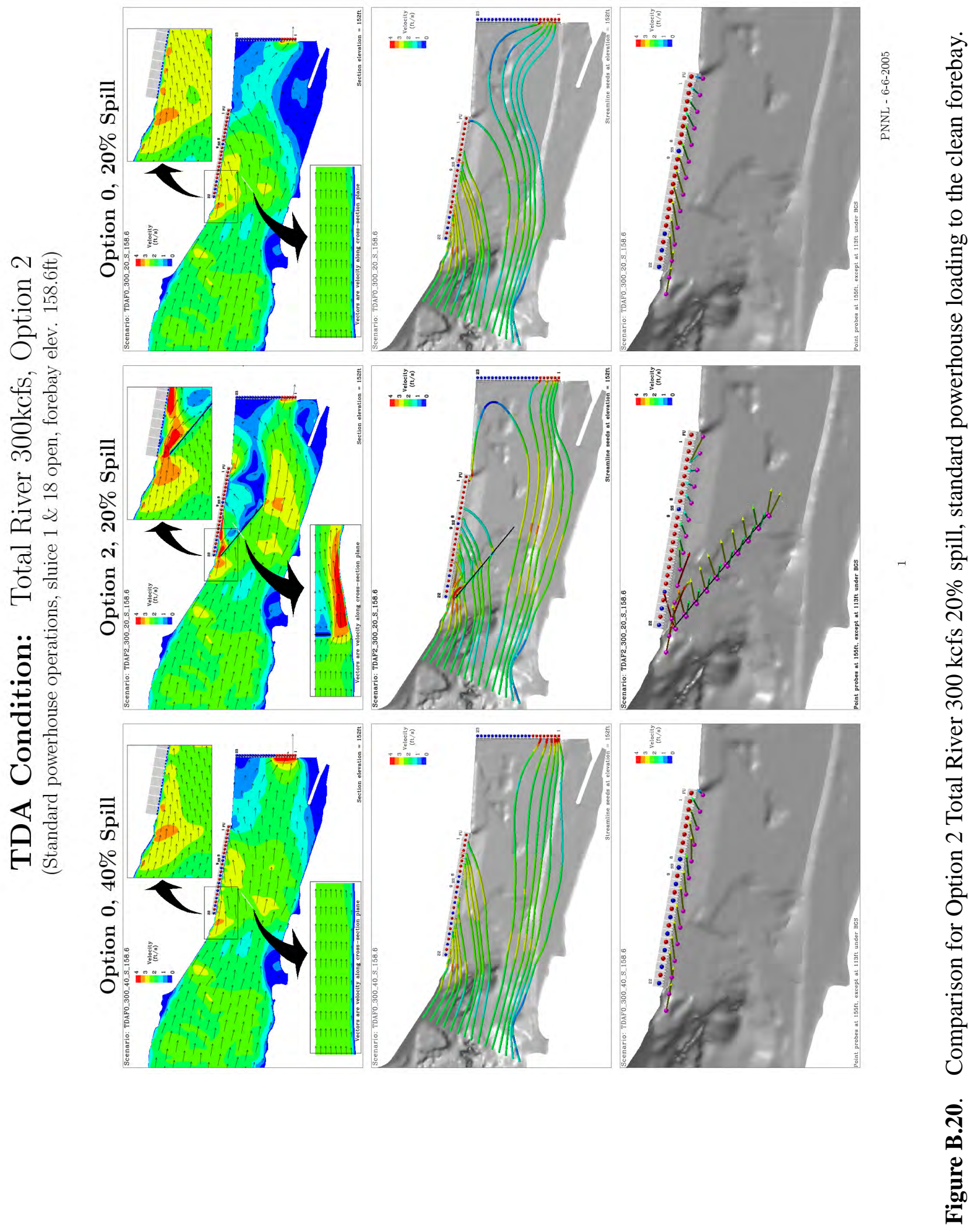




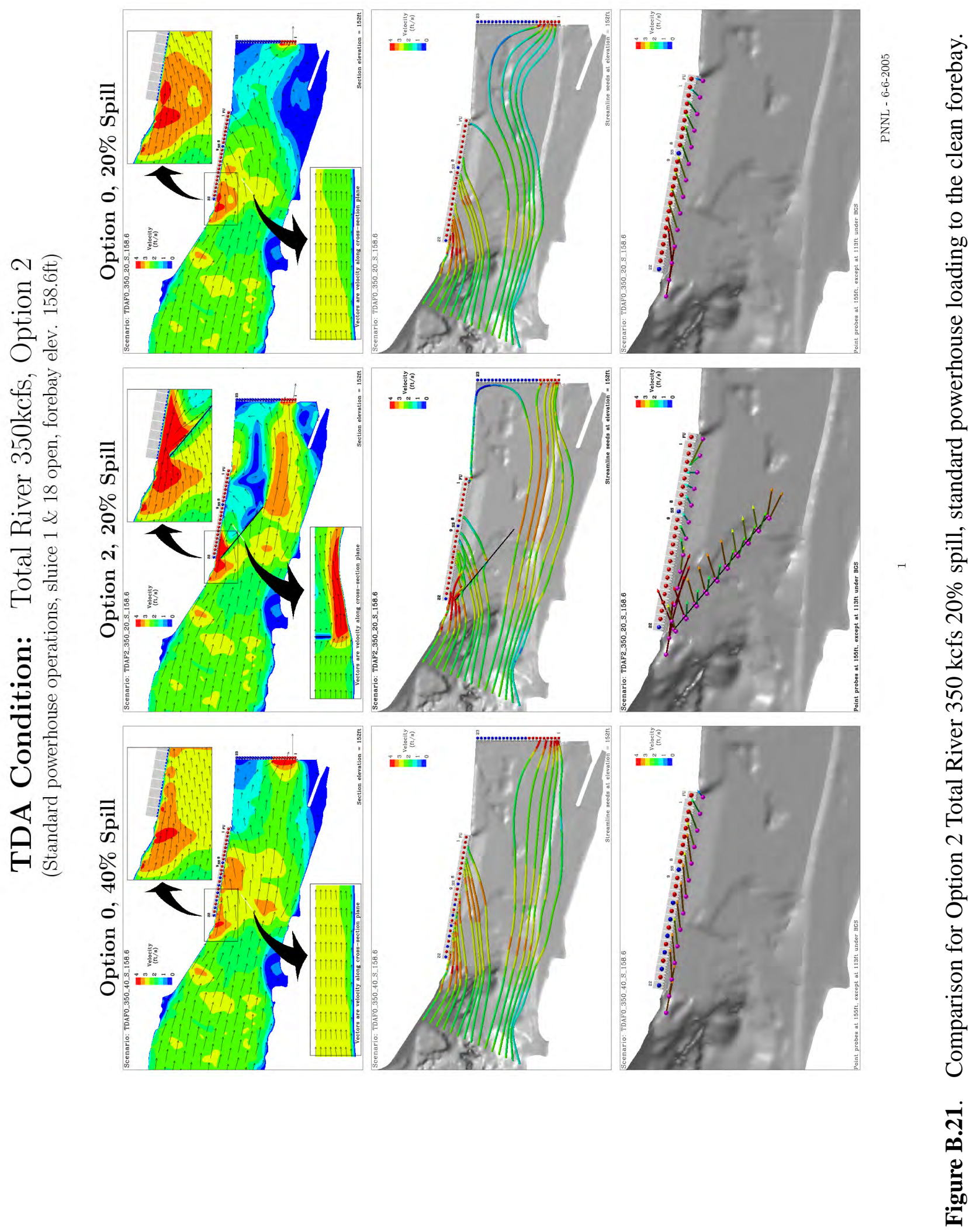




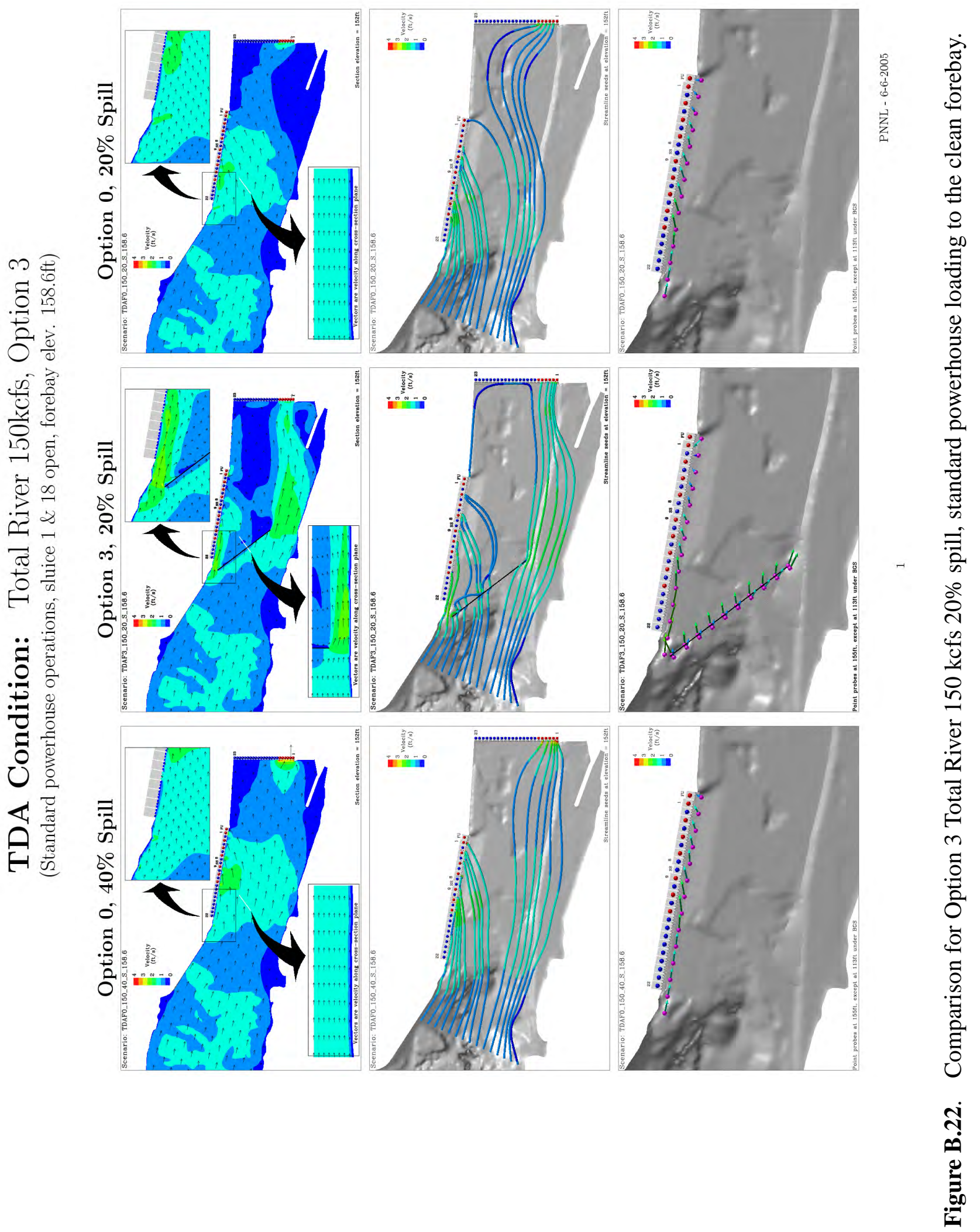




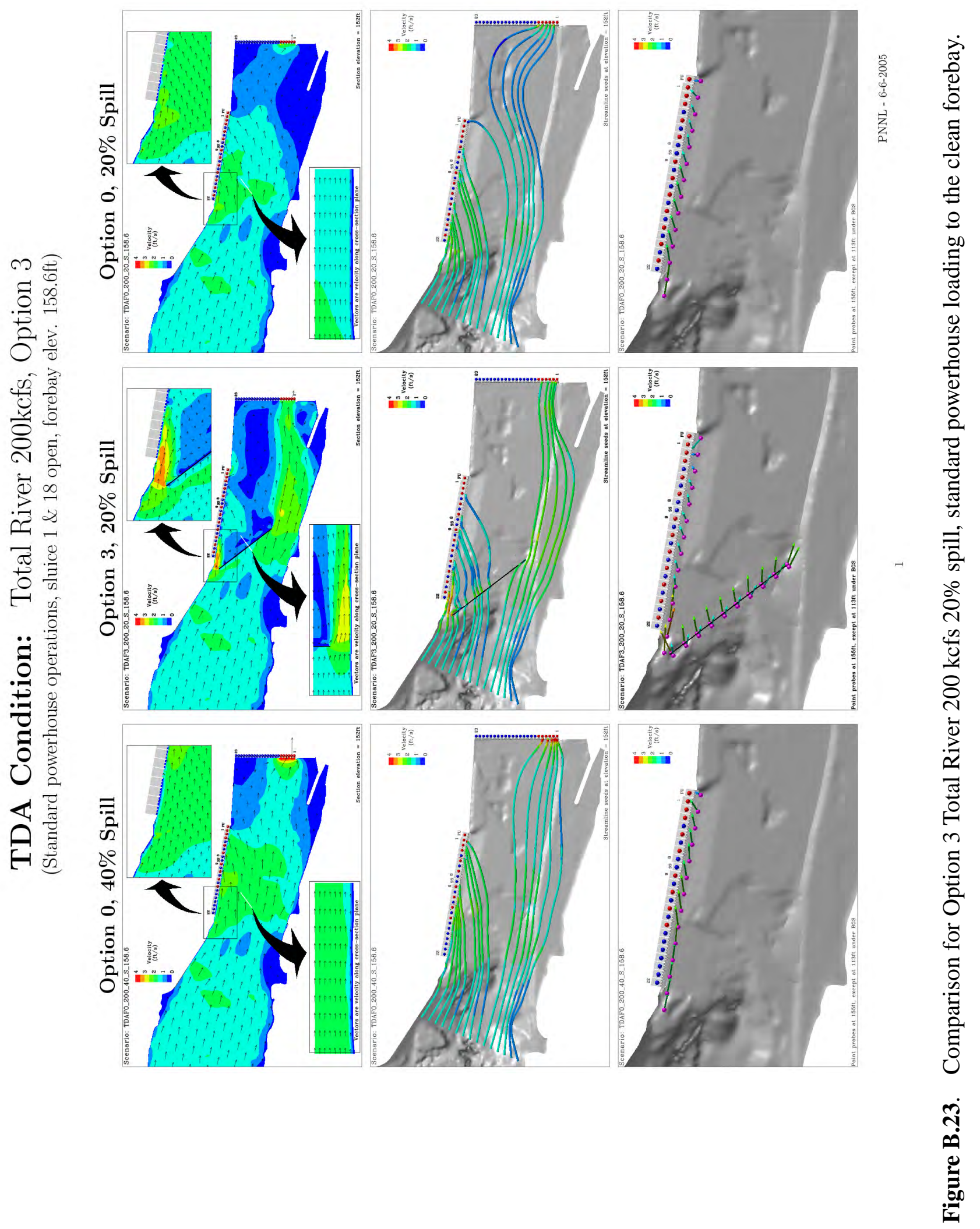




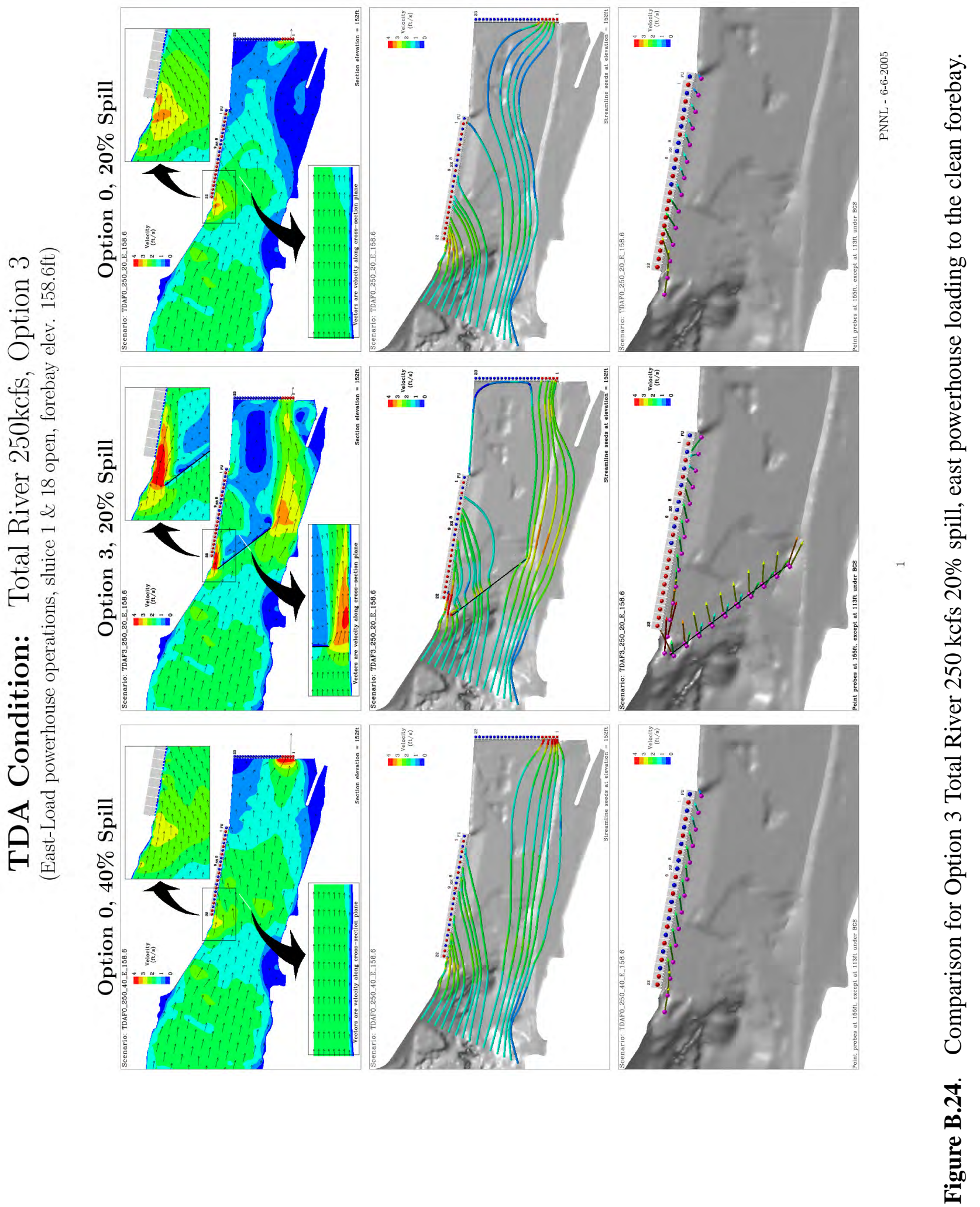




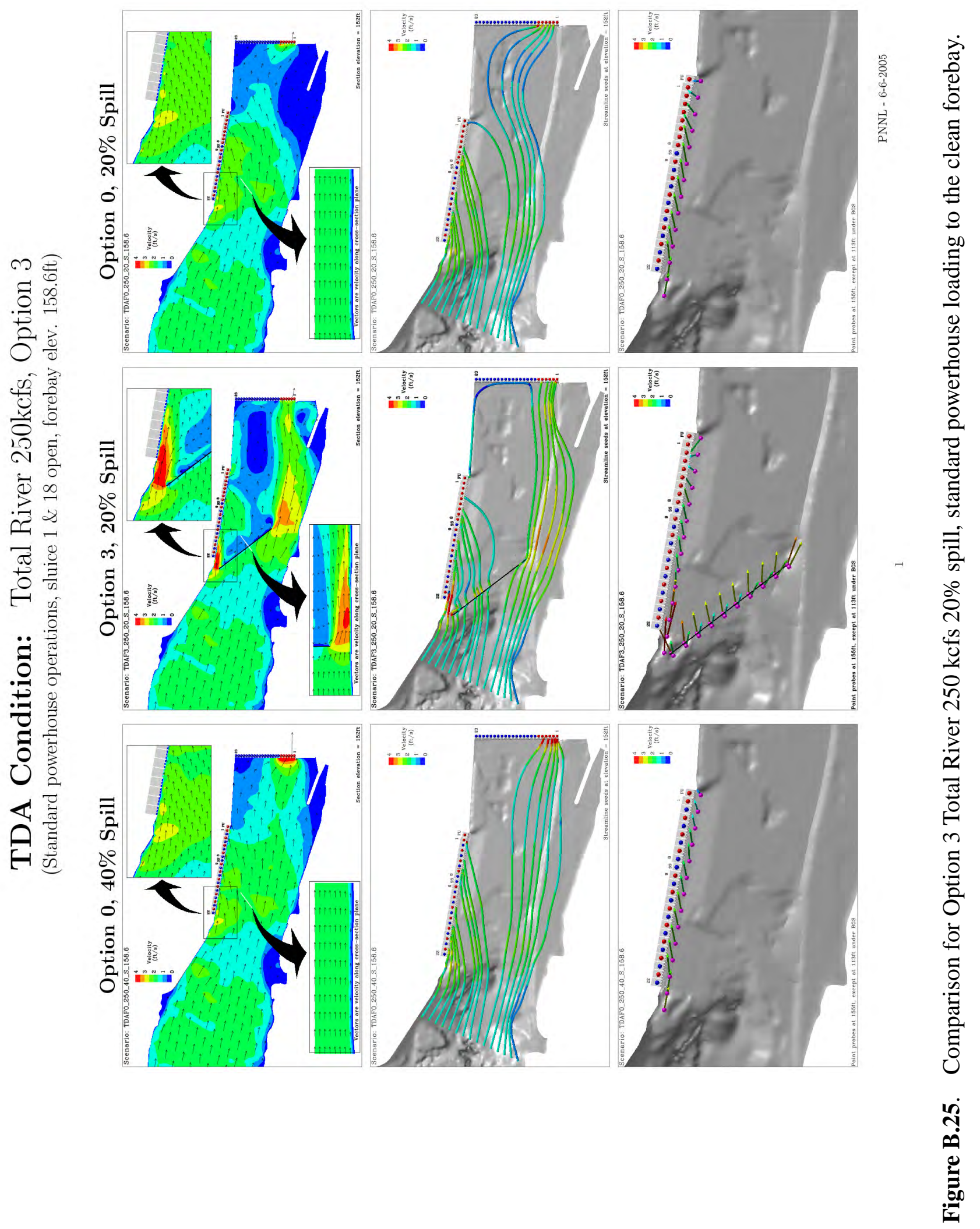



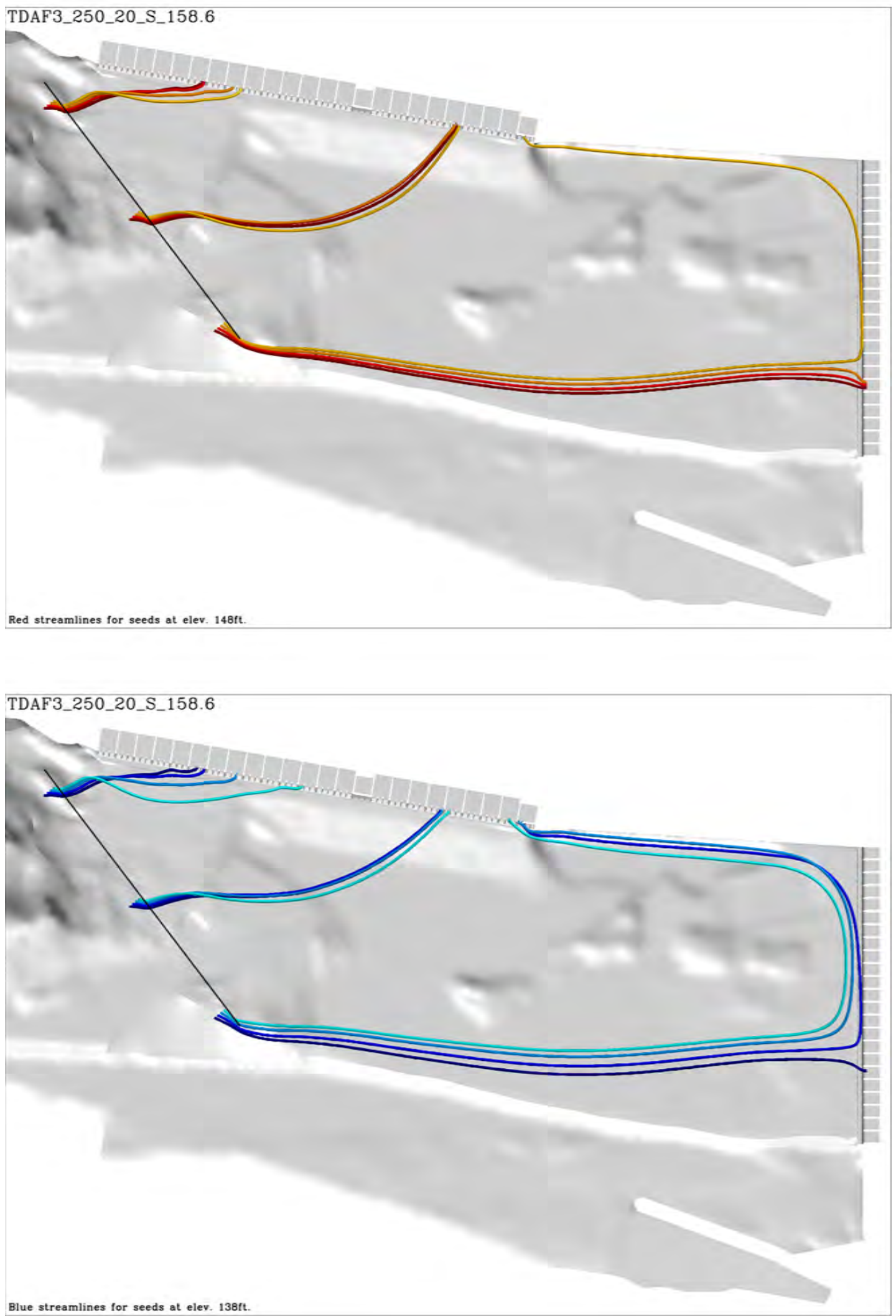

Figure B.26. Option 3 streamlines for particles released near the BGS at elevation $138 \mathrm{ft}$. Total River $250 \mathrm{kcfs} 20 \%$ spill, standard powerhouse loading.

B. 25 


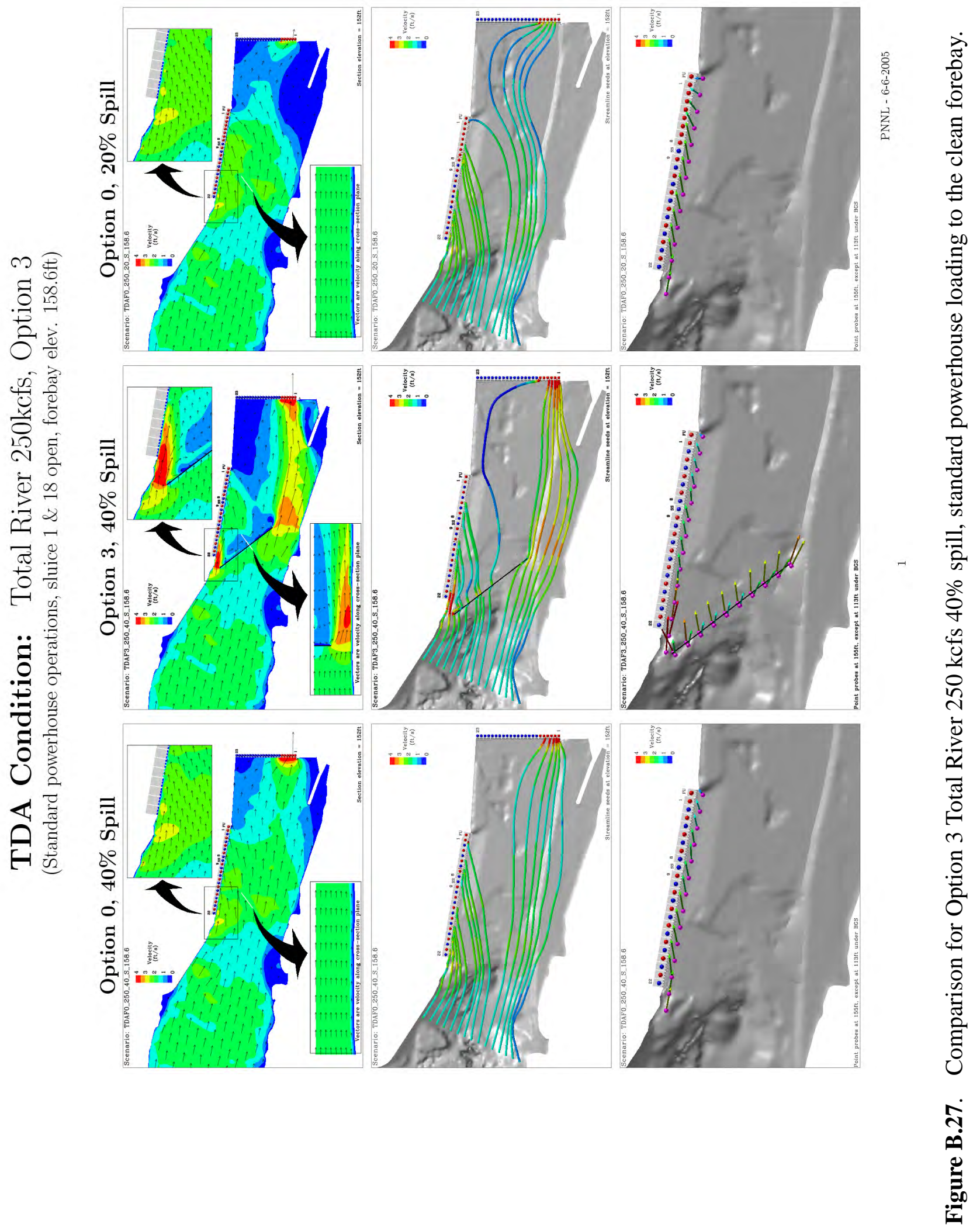




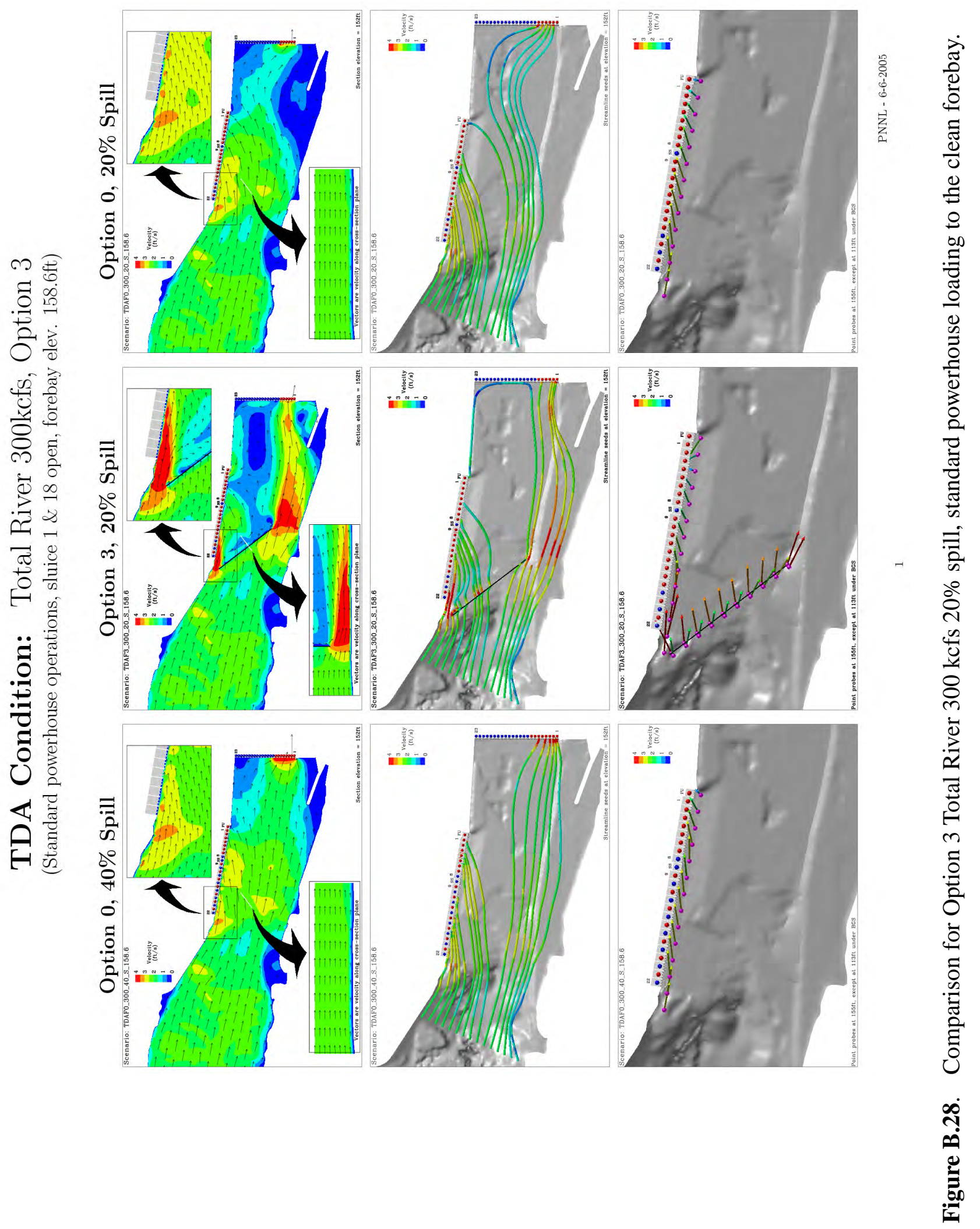




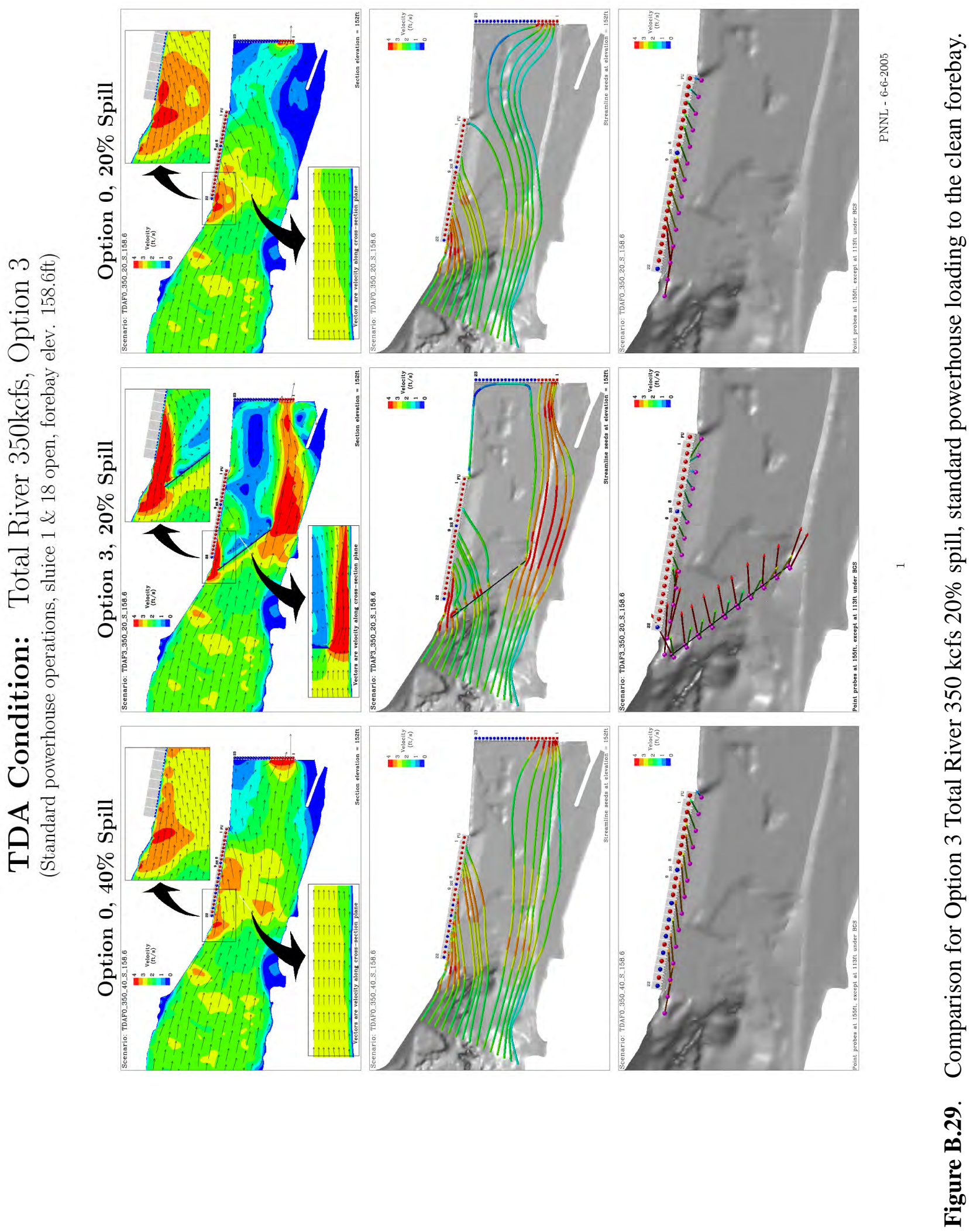




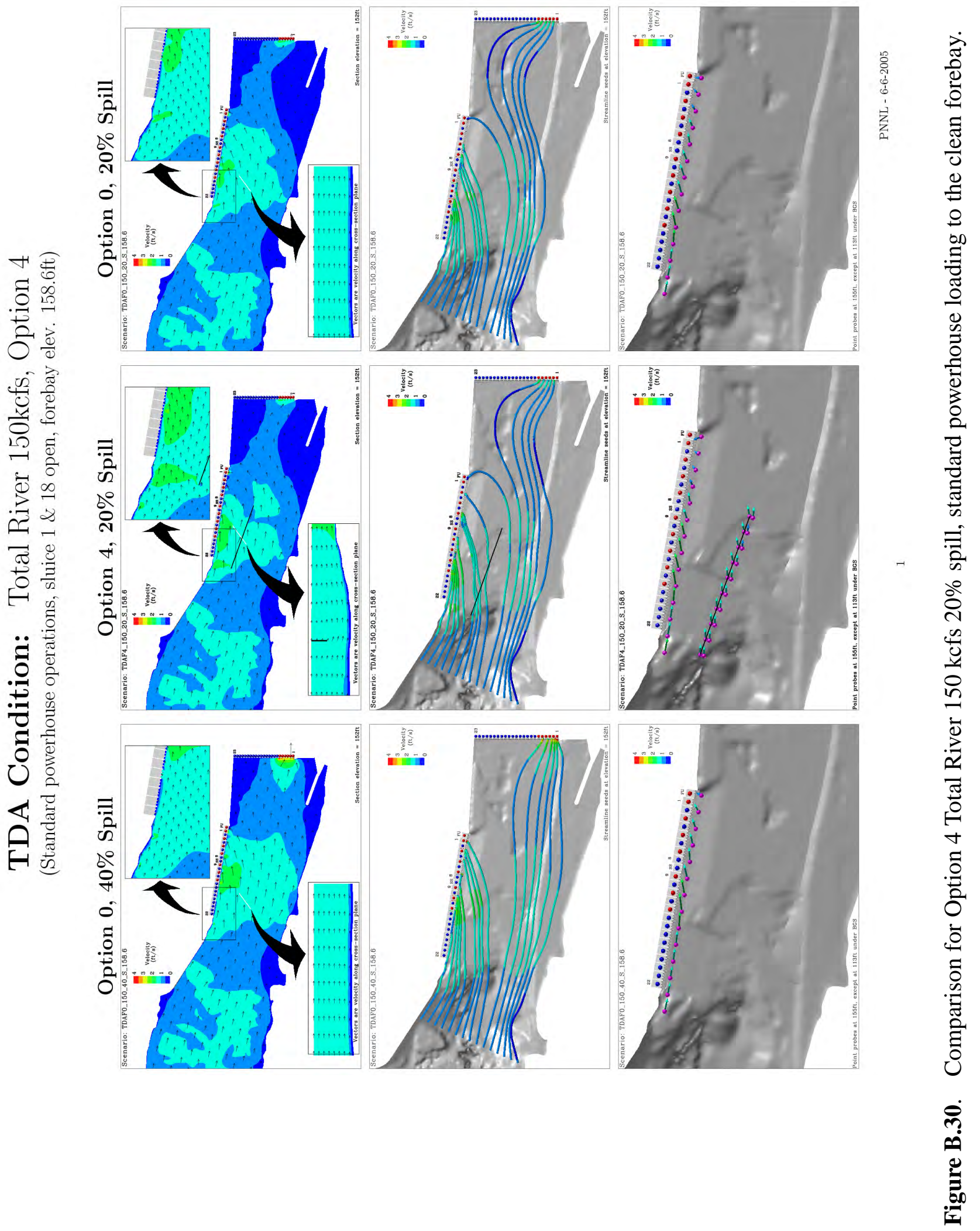




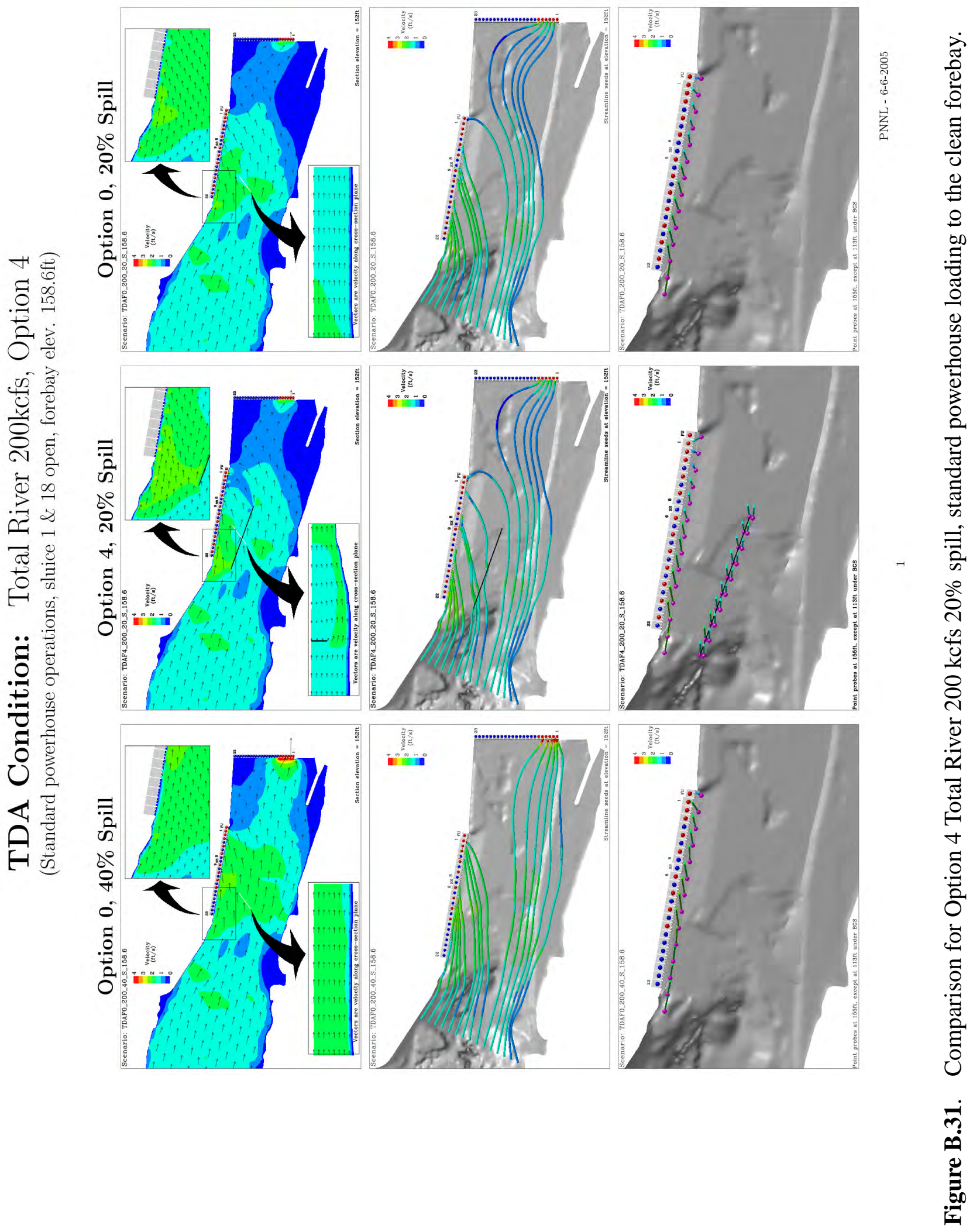




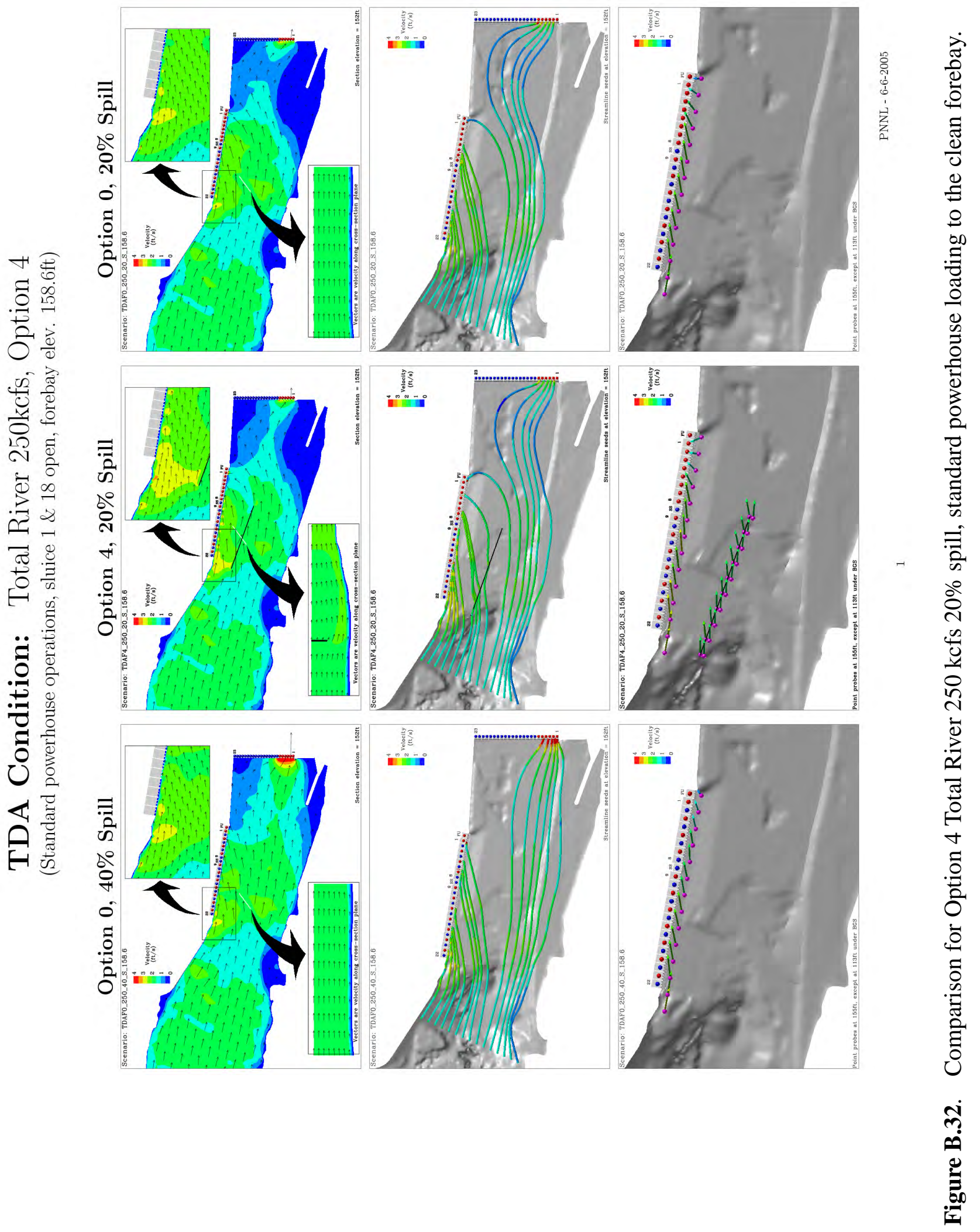



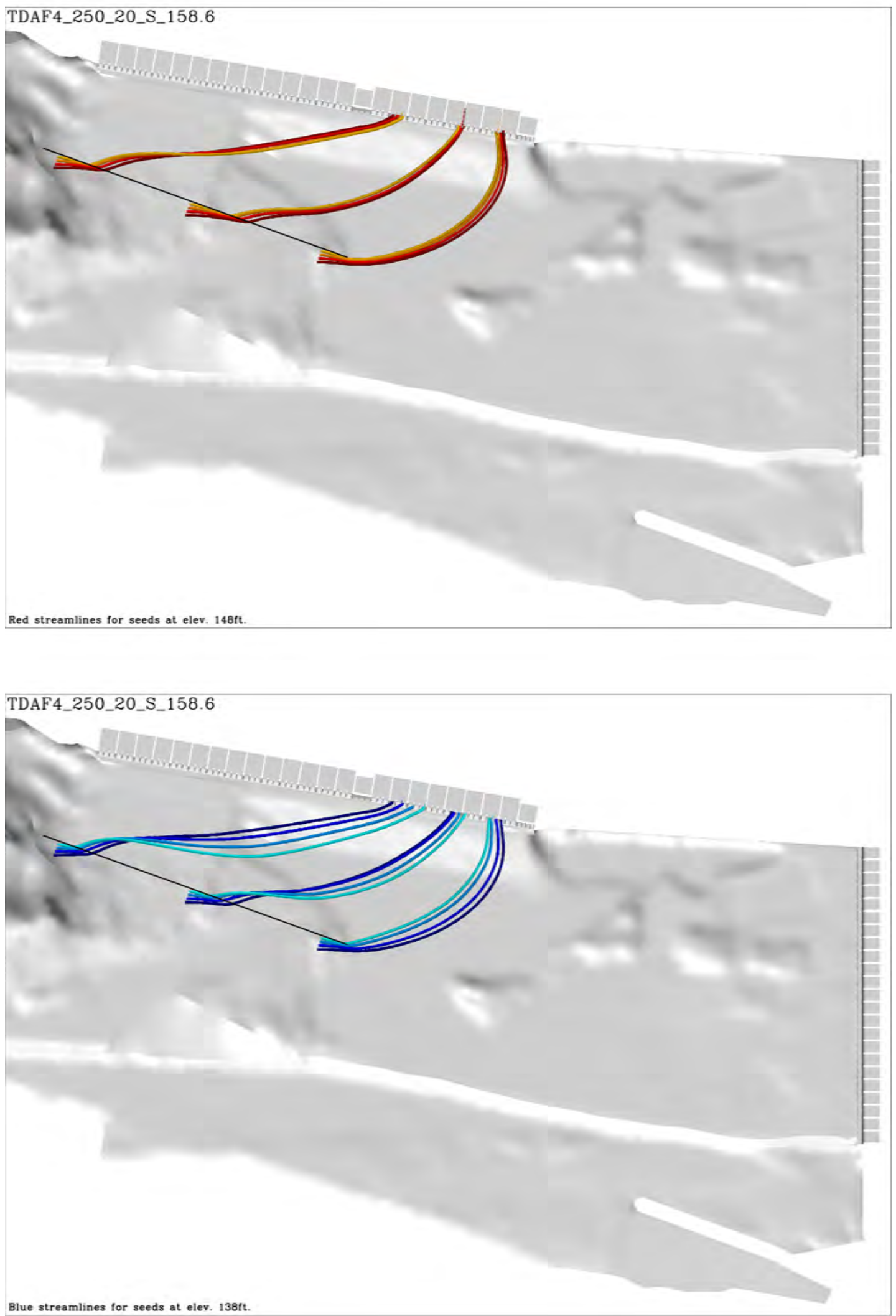

Figure B.33. Option 4 streamlines for particles released near the BGS at elevation $138 \mathrm{ft}$. Total River $250 \mathrm{kcfs} 20 \%$ spill, standard powerhouse loading.

B.32 


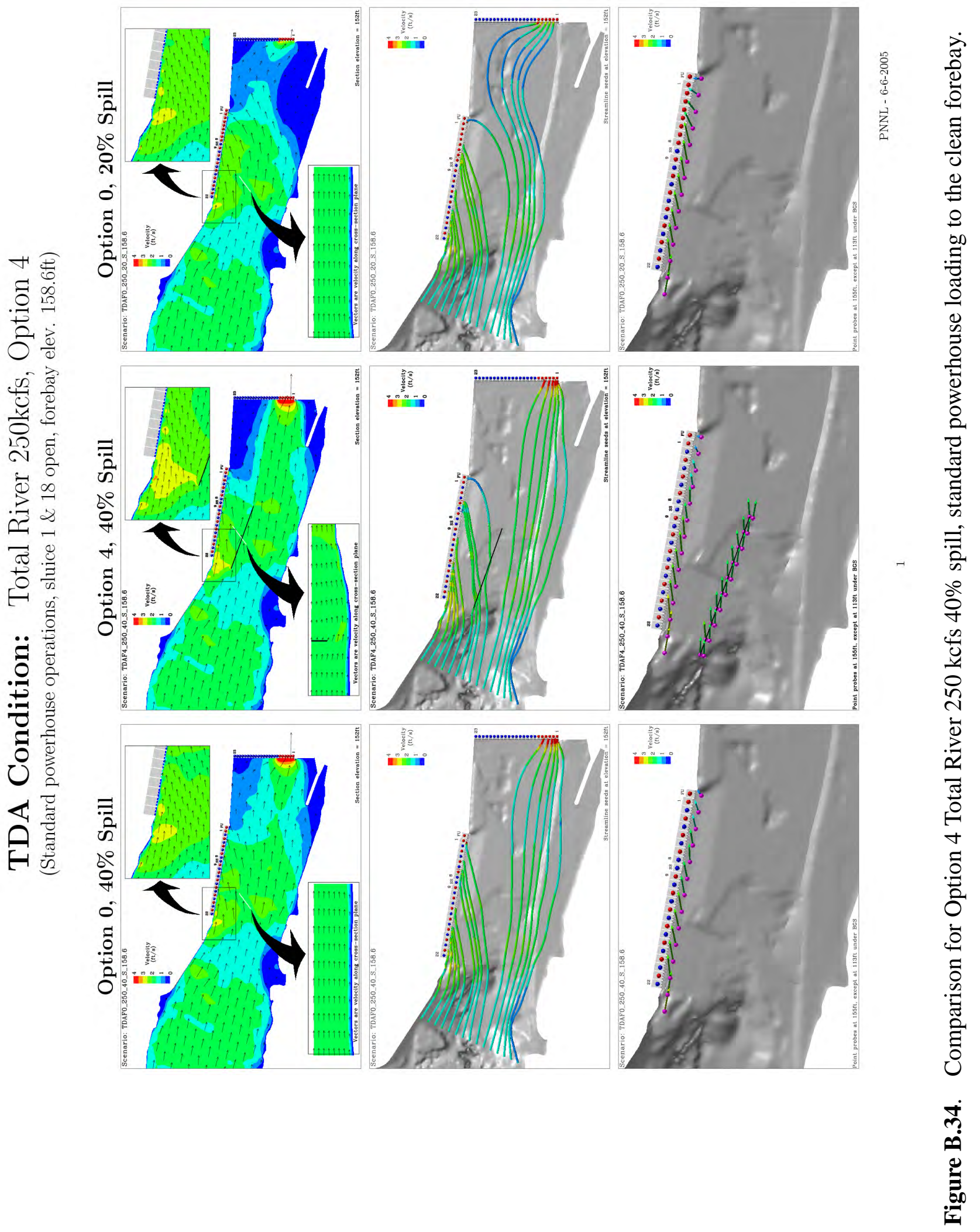




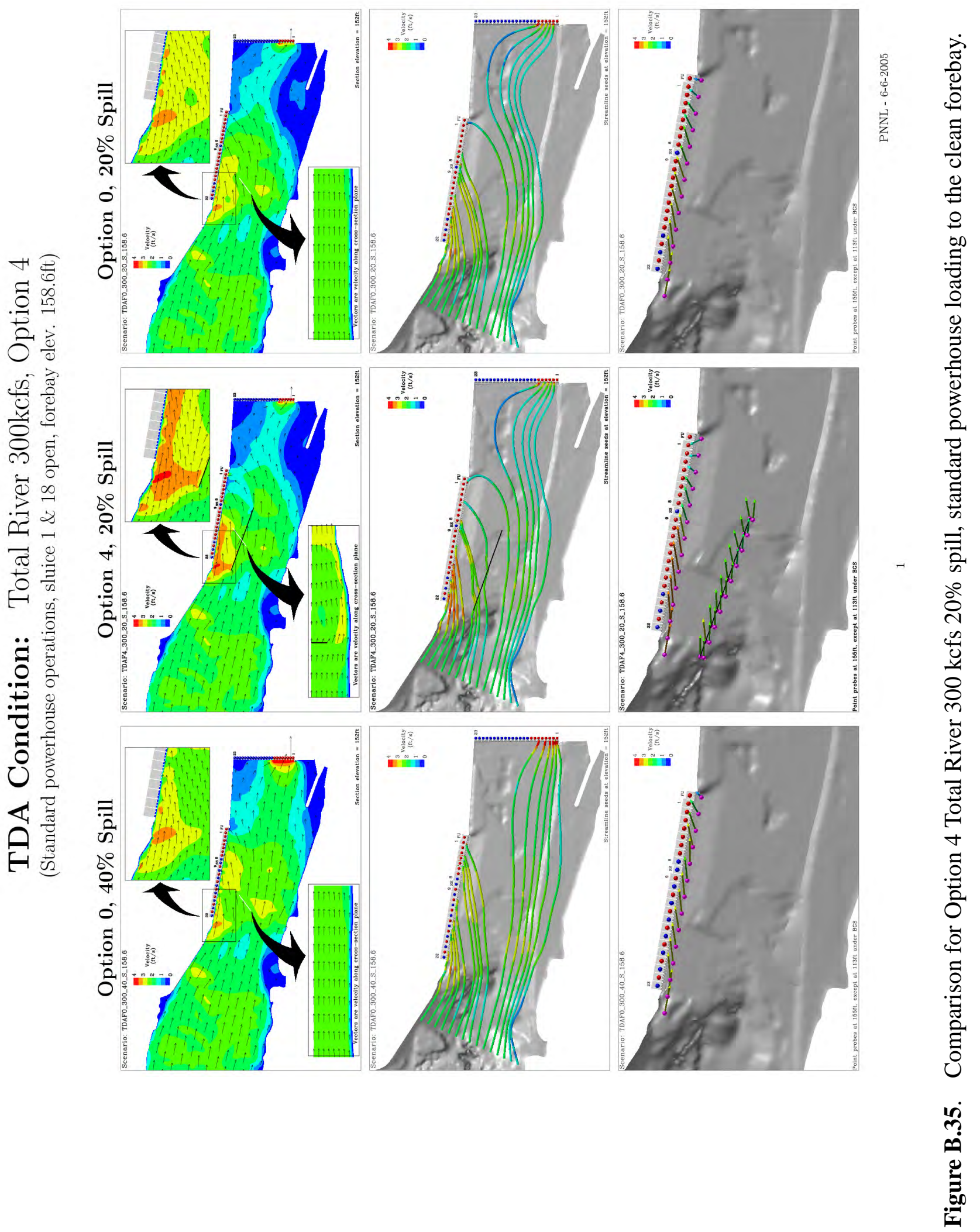




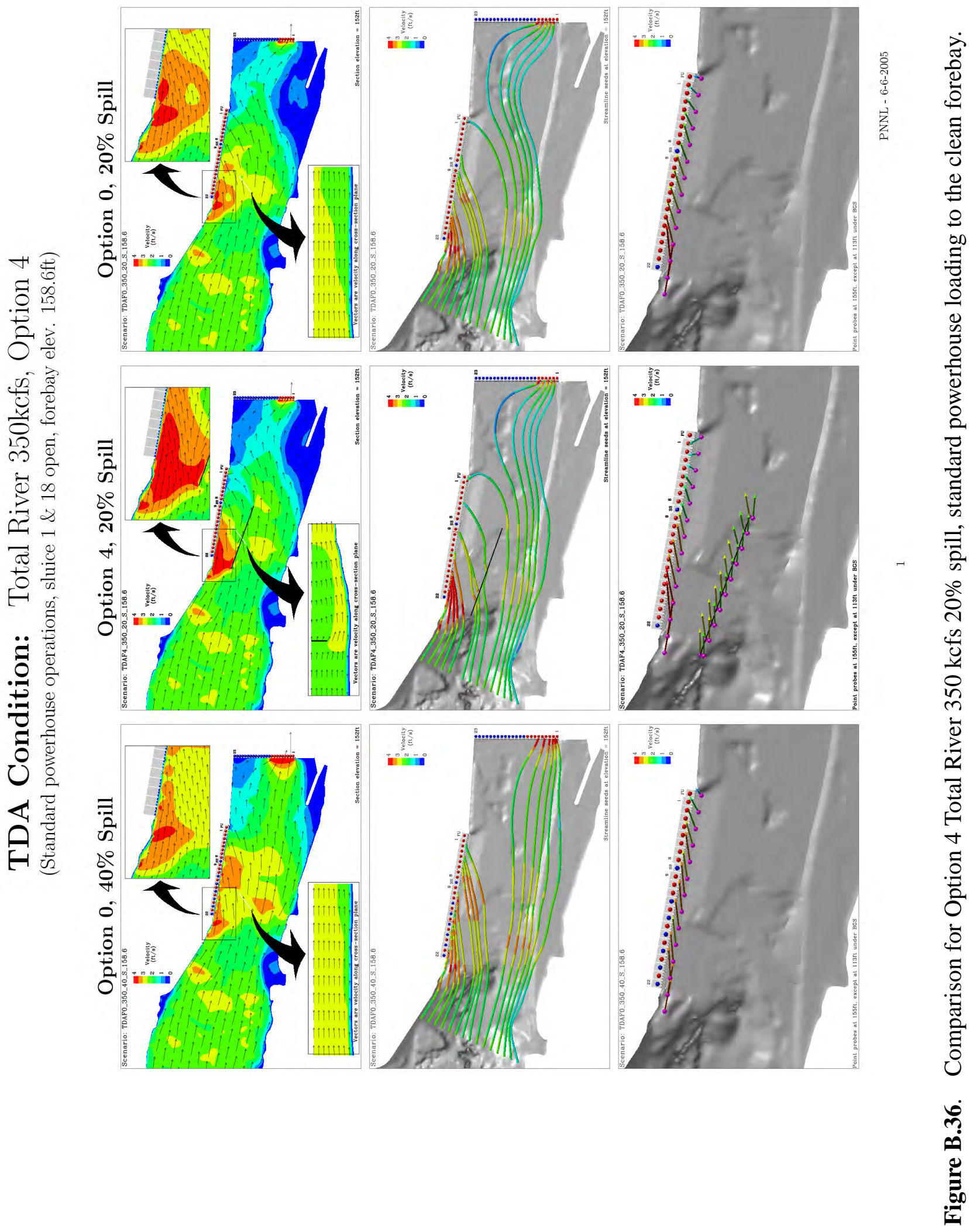




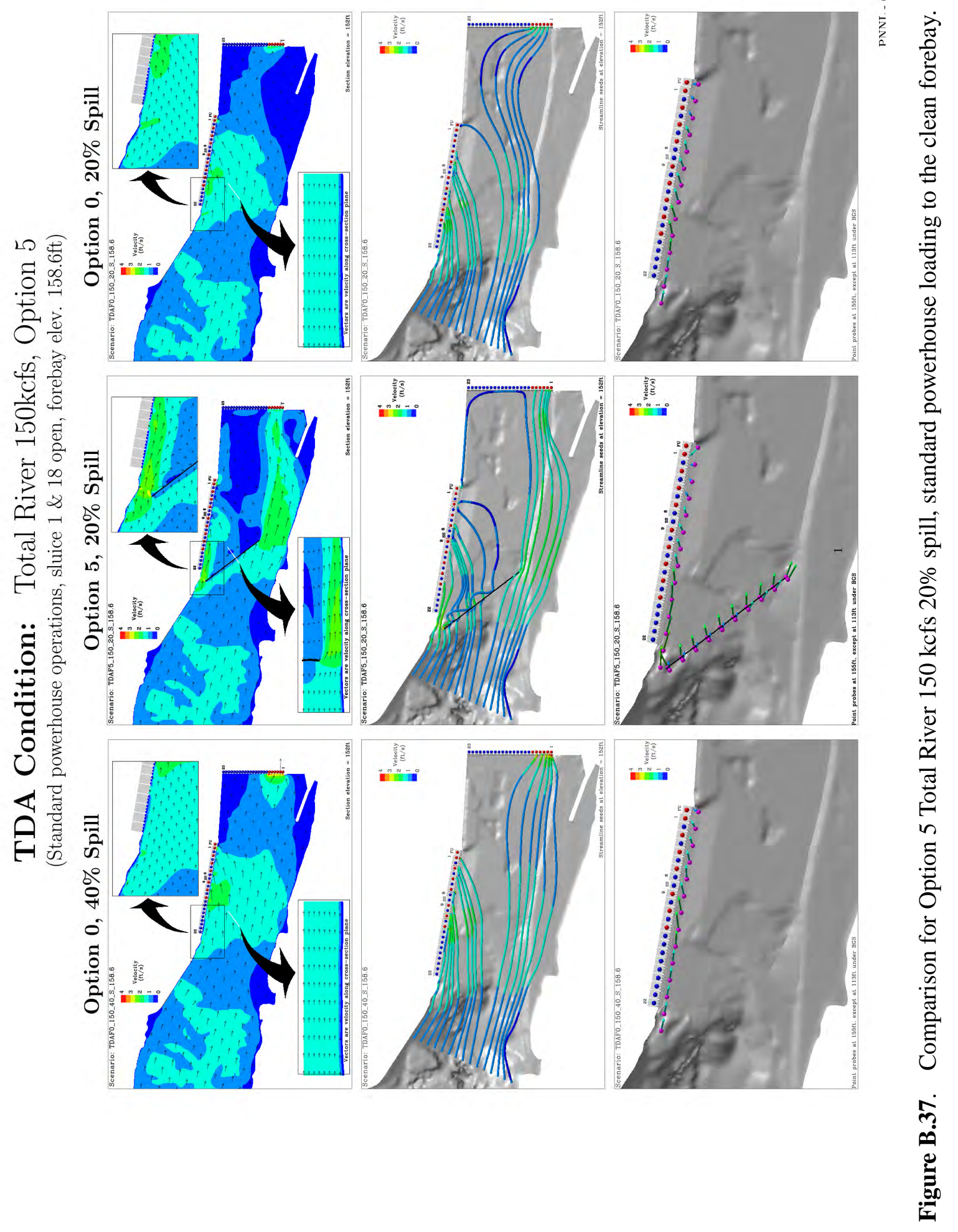




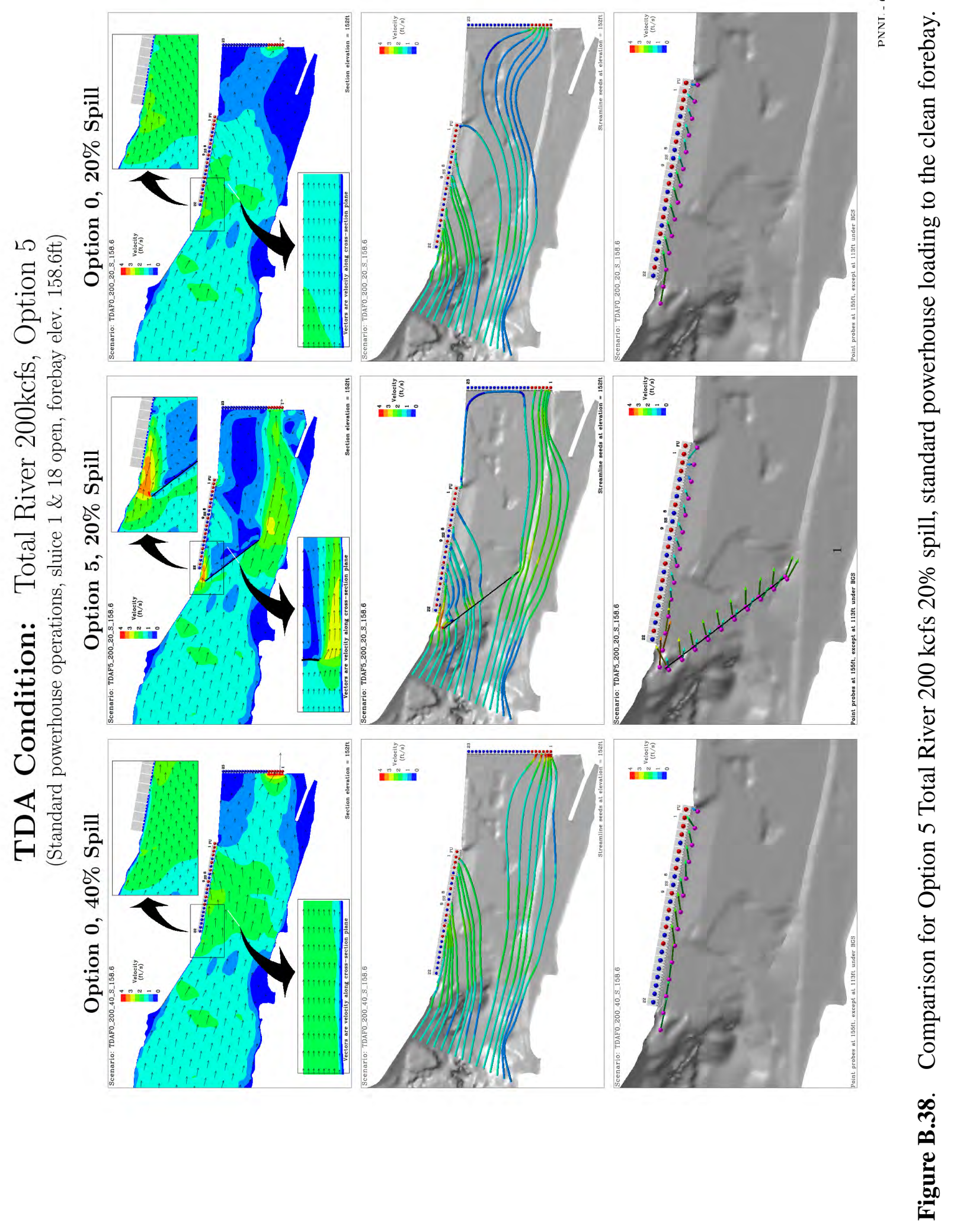




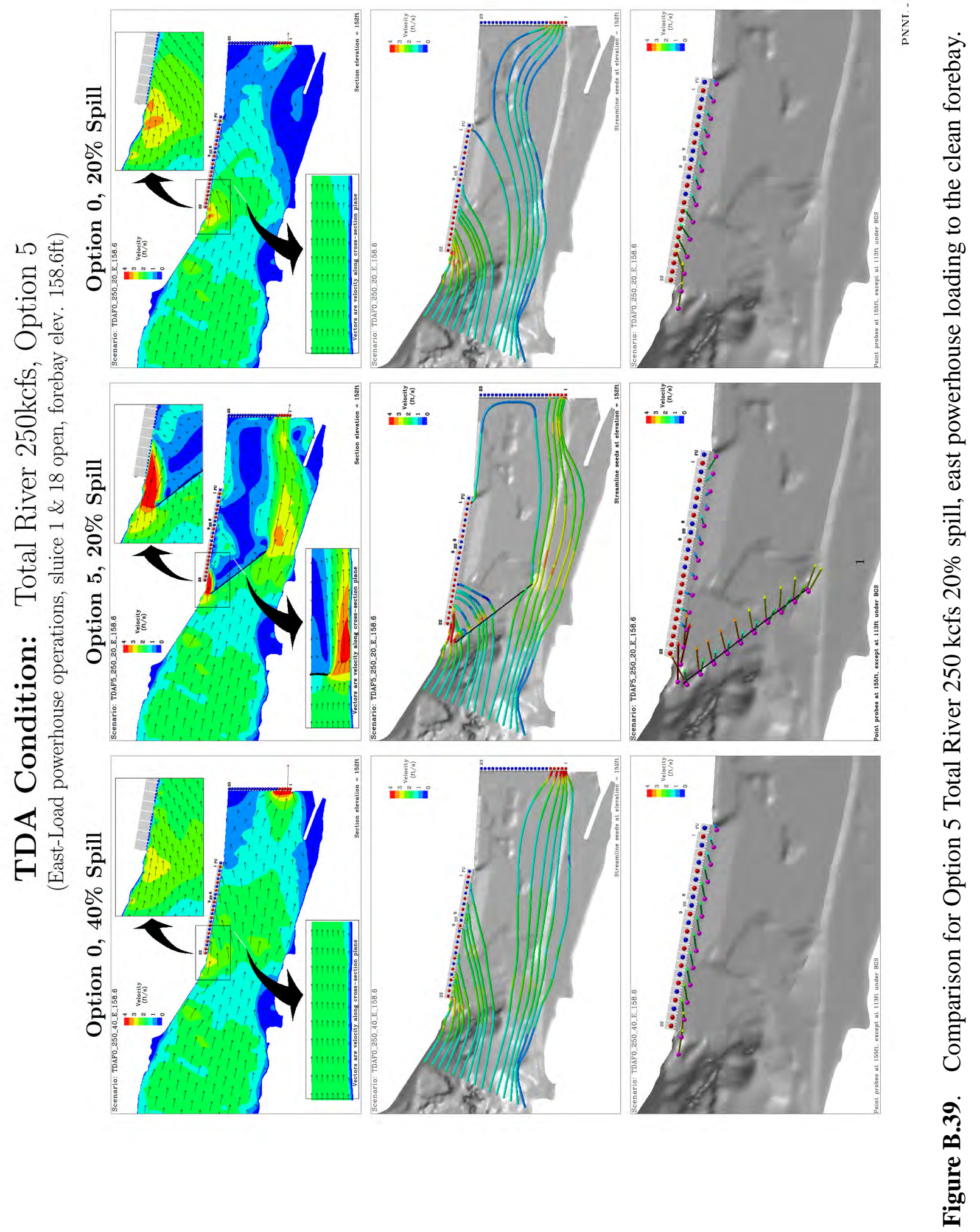




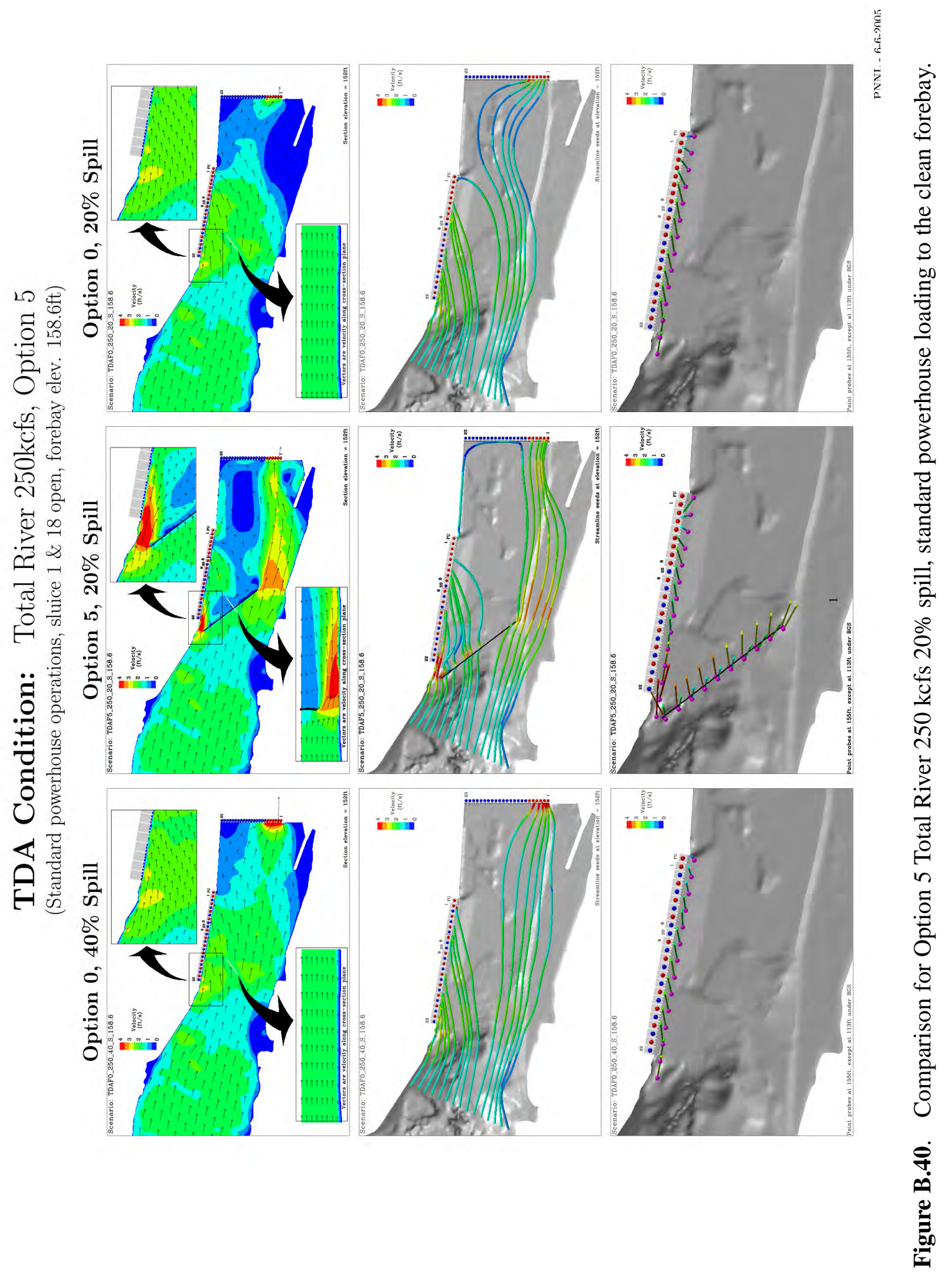




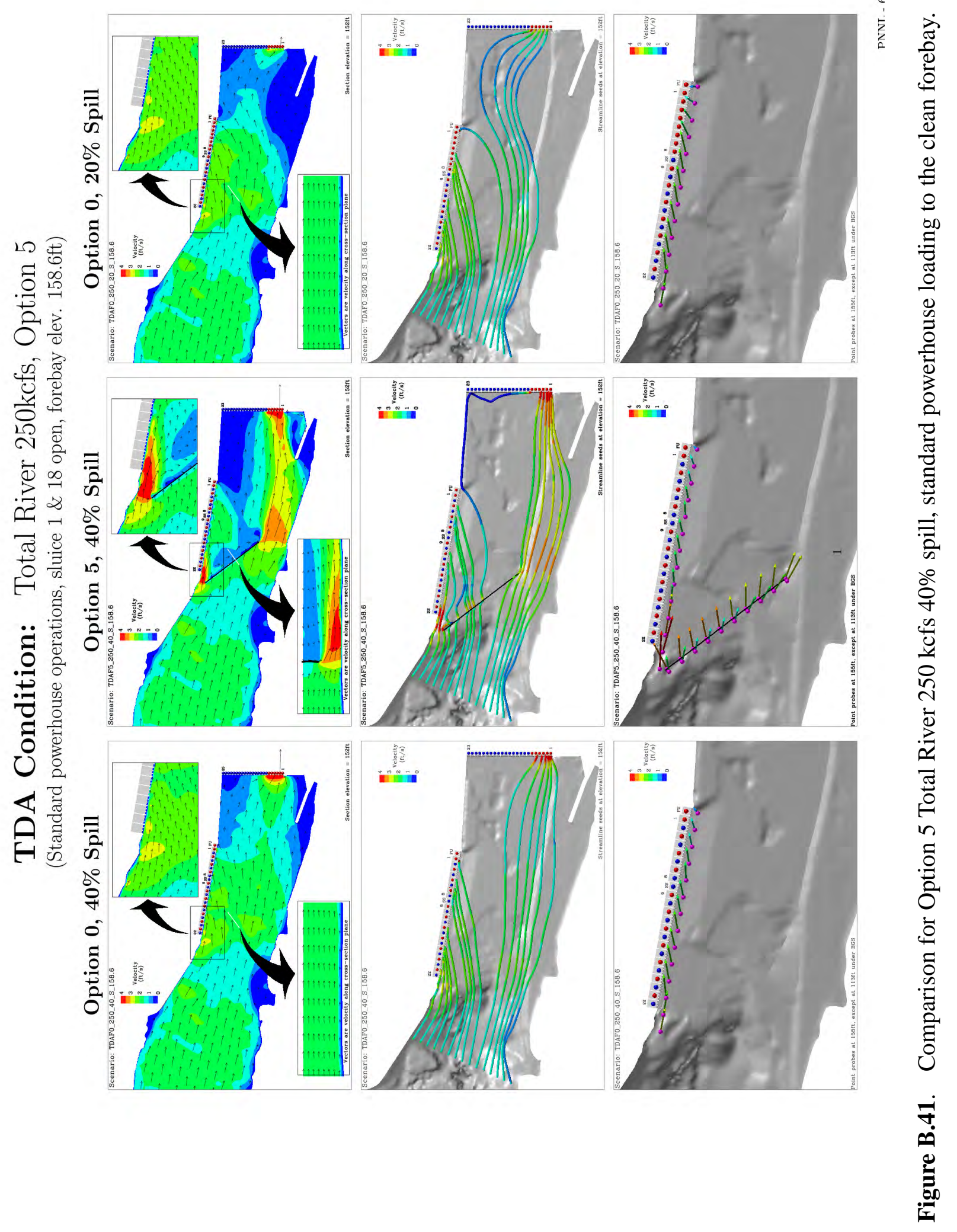




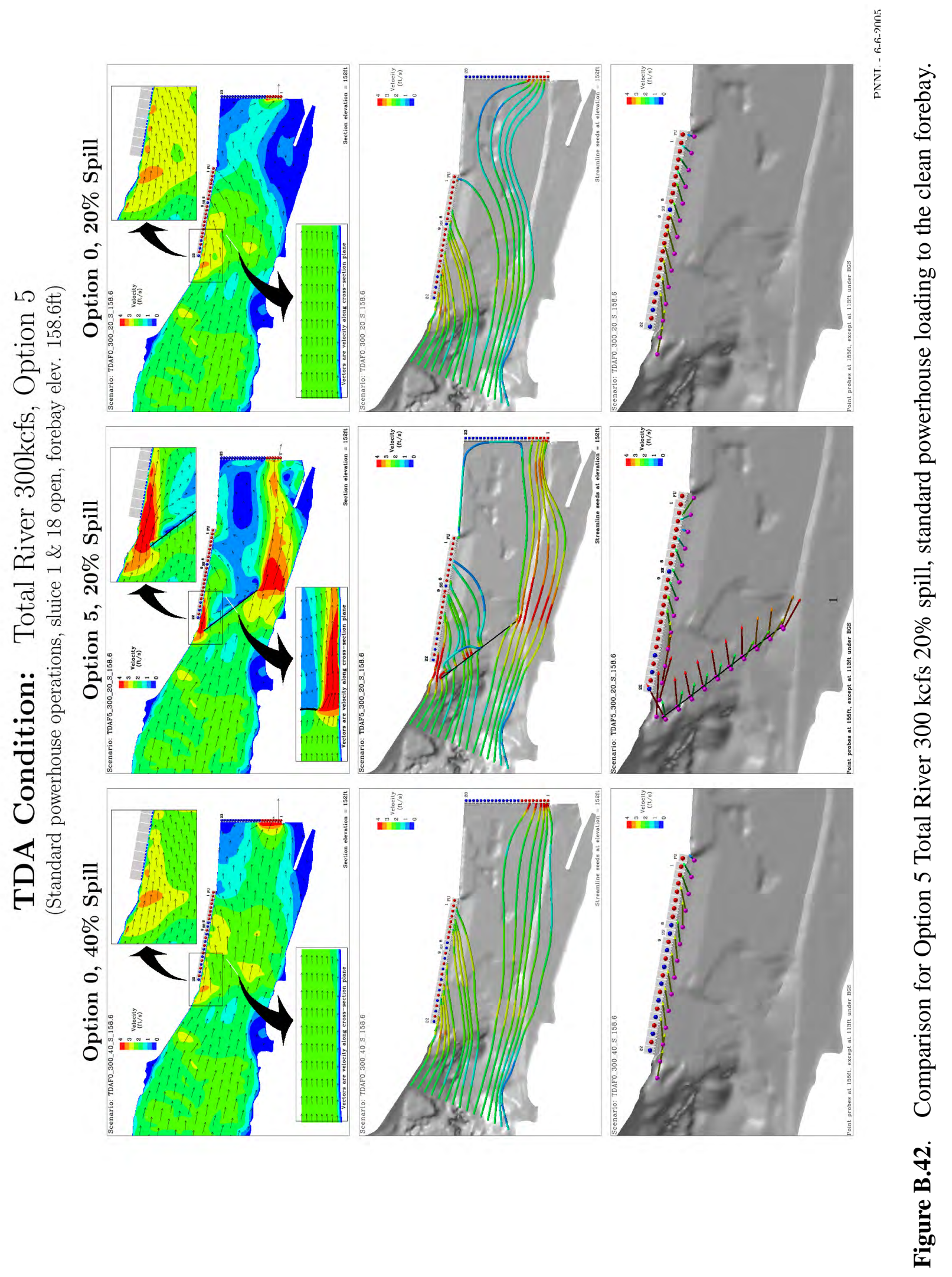




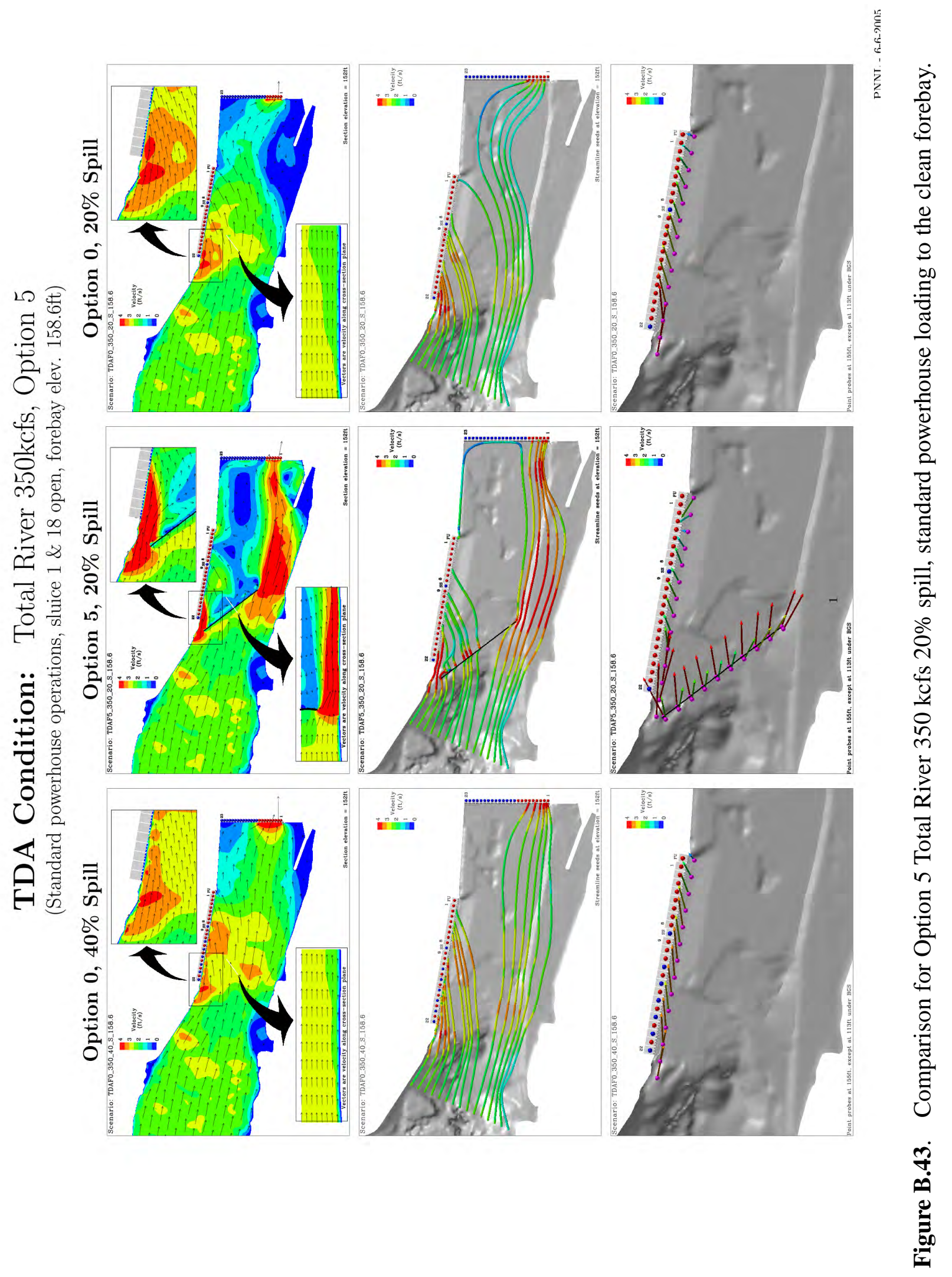




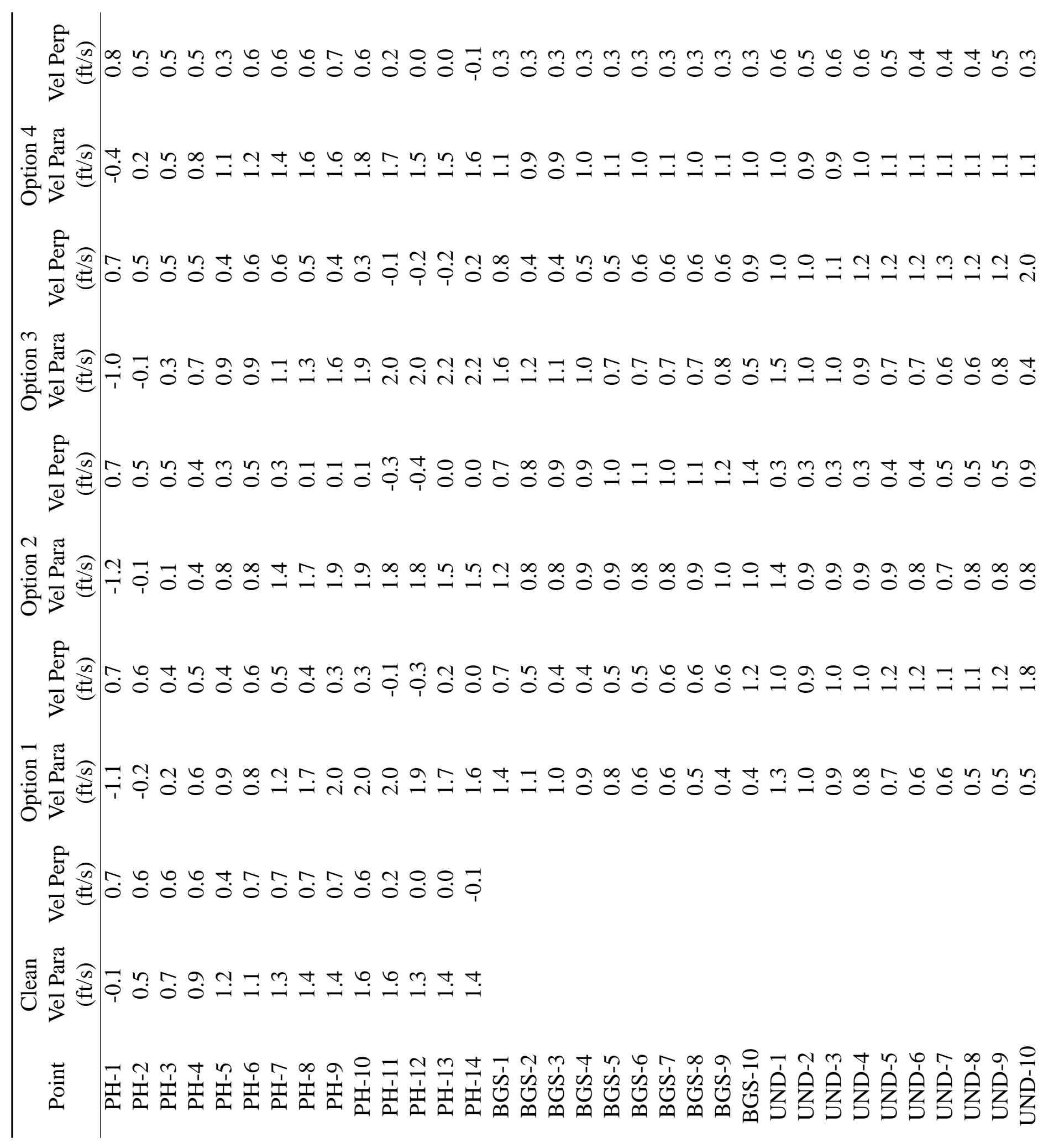




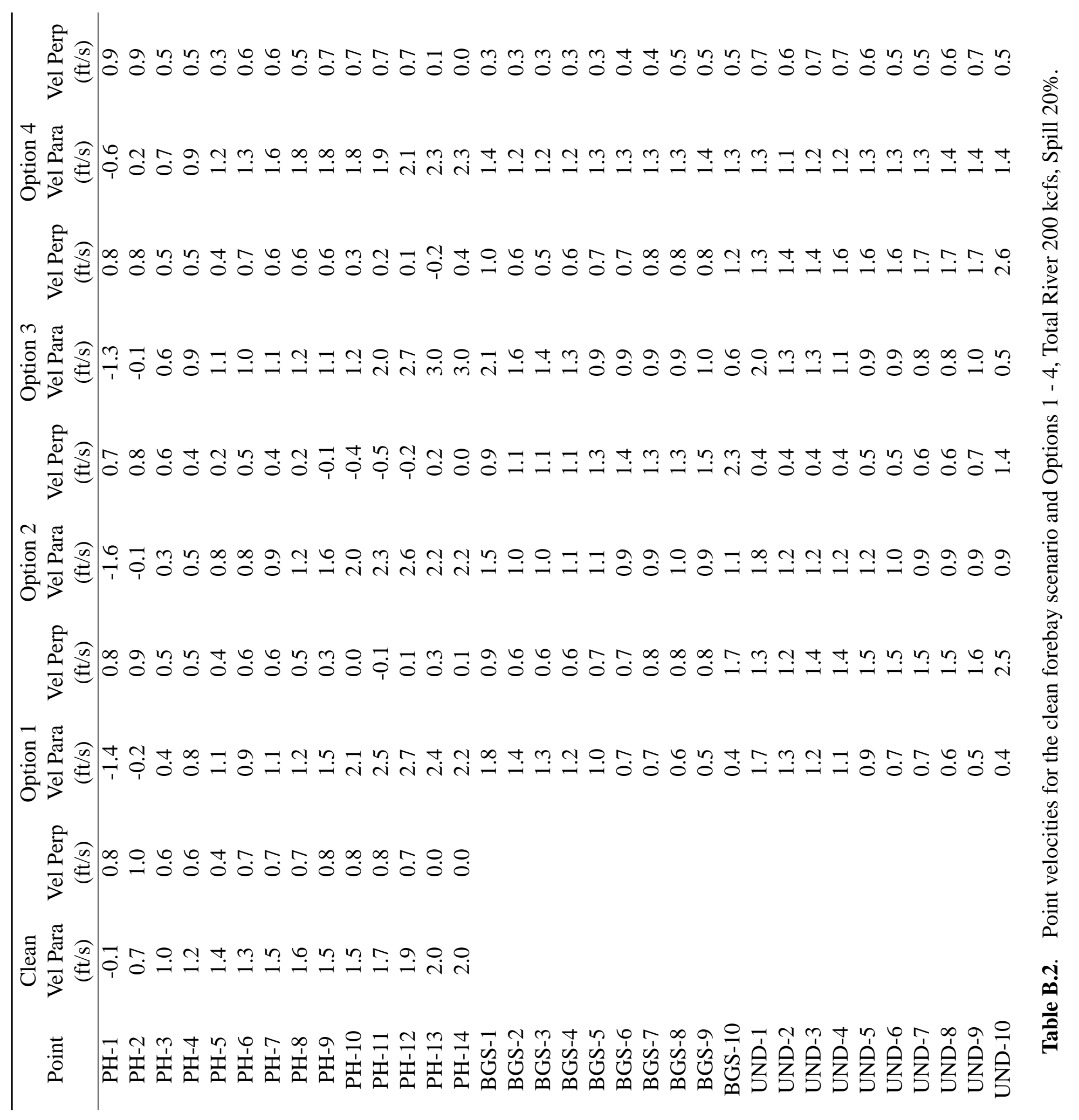




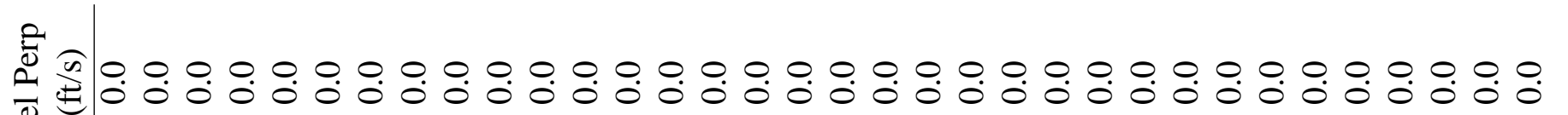
$>$

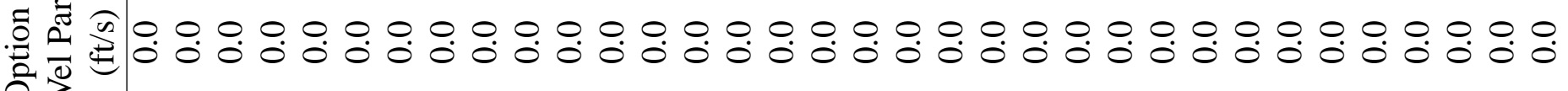

e

Dै

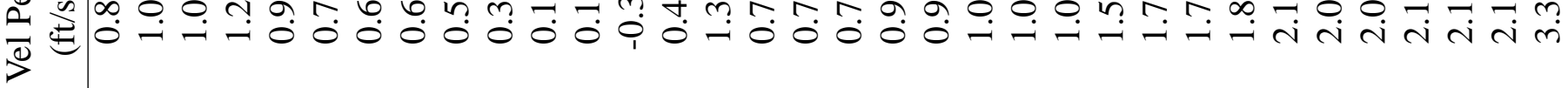

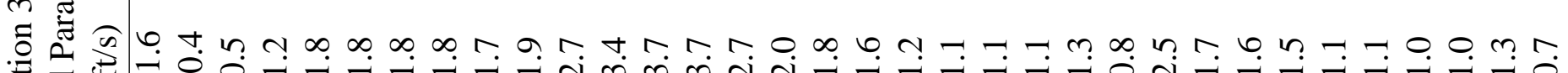

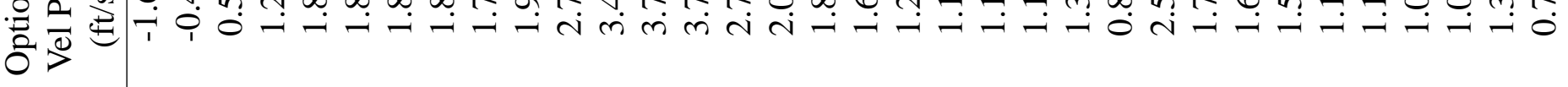

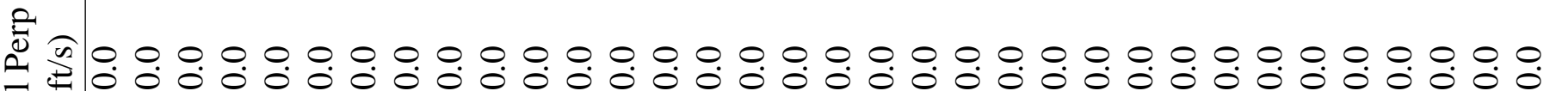

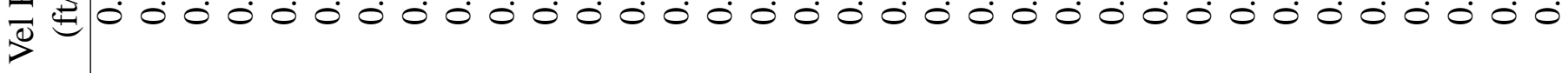

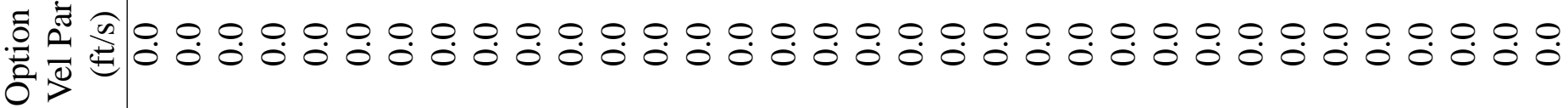

?ำ

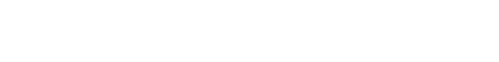

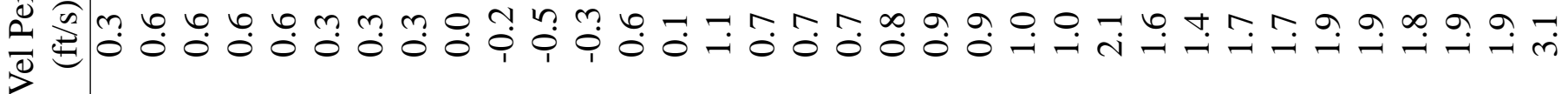

$\overline{7}$

官

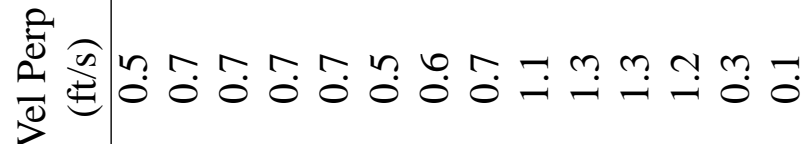

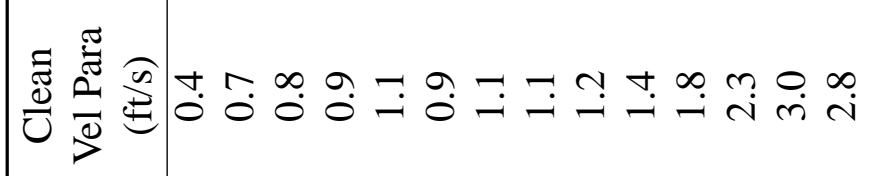

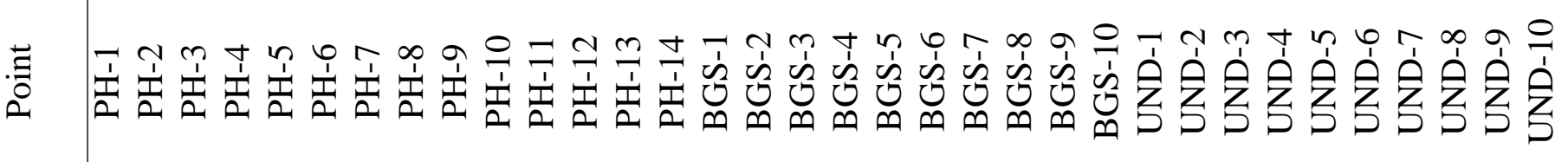




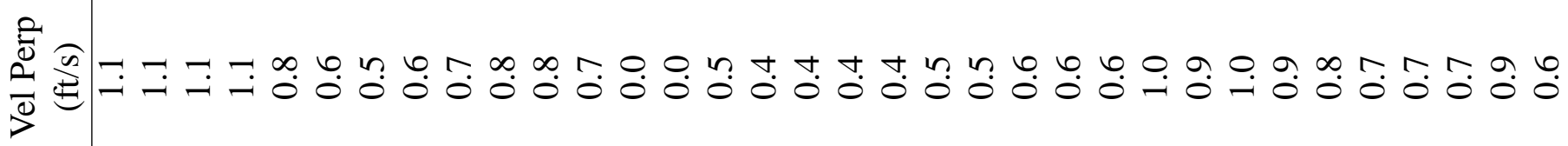

ปี

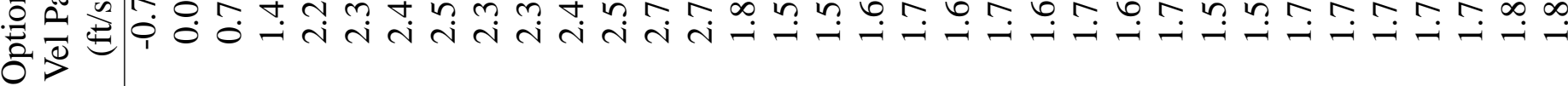

$\stackrel{2}{0}$

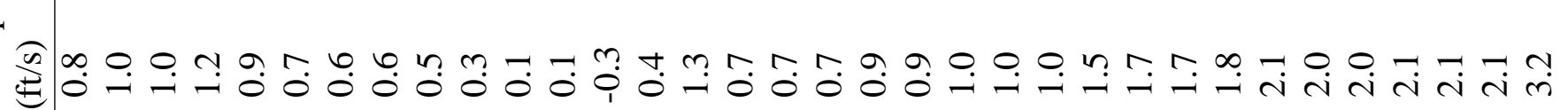
ग

氙

닌

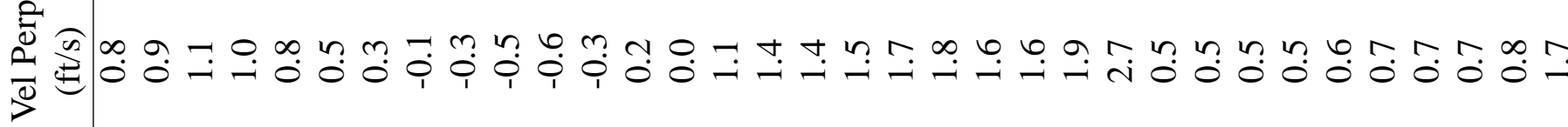

N

oี

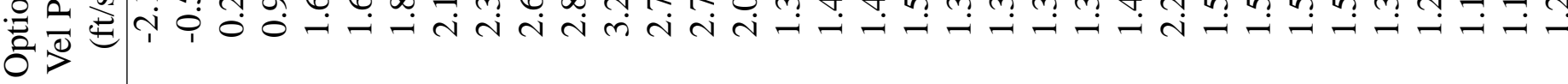

बֶ,

(2)

ए)



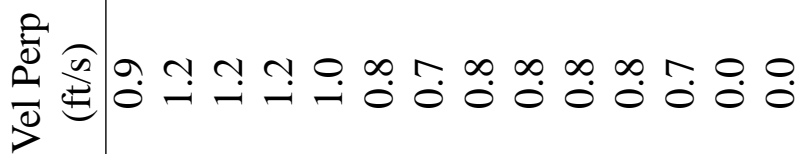

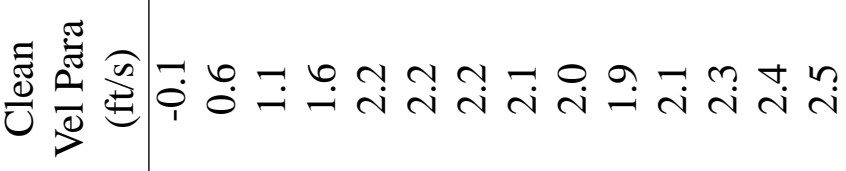

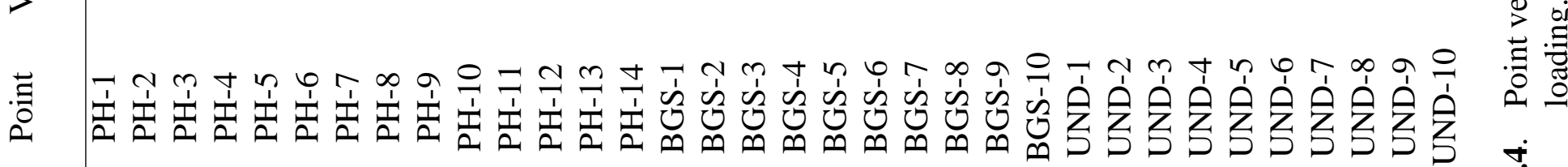




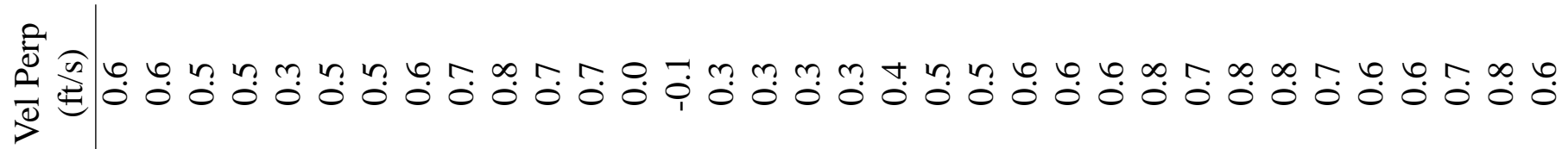

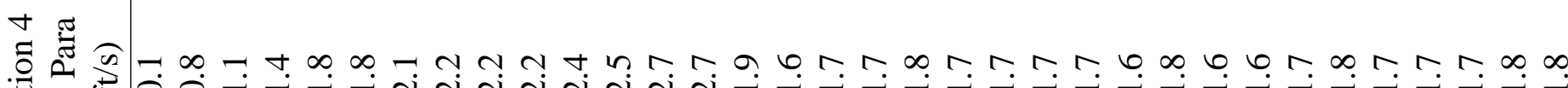

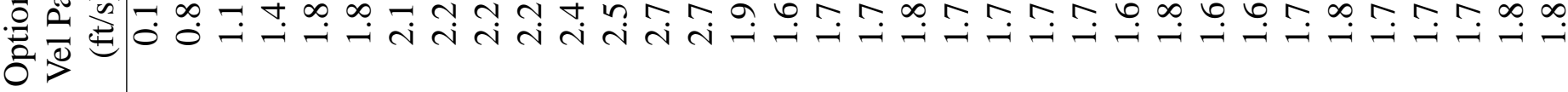

$\stackrel{2}{0}$

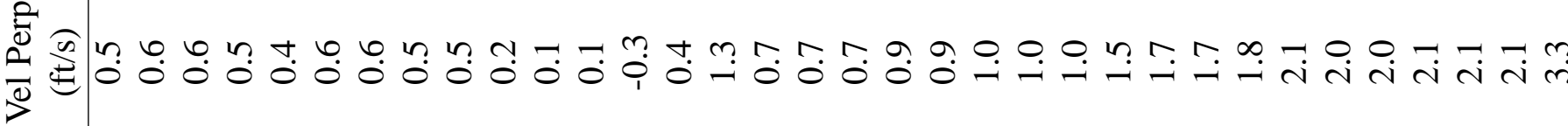

m

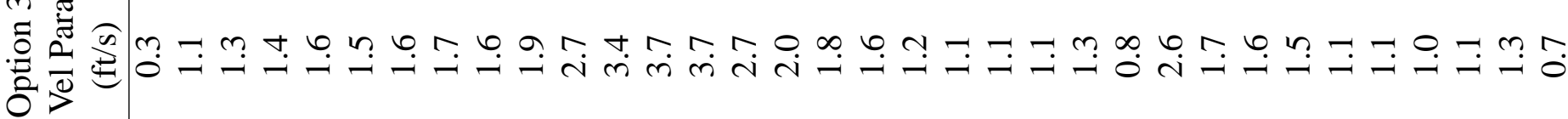

$\stackrel{\varrho}{0}$

อ $\stackrel{\square}{>}$

r

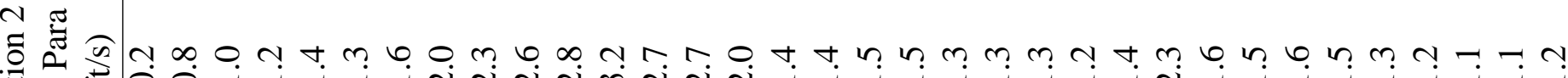

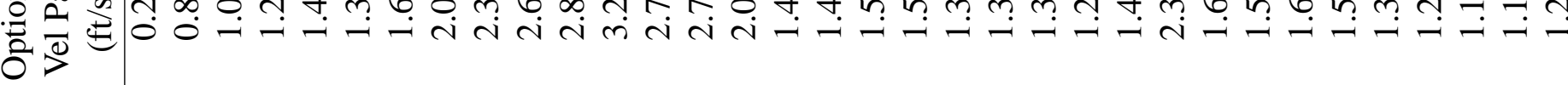

$\stackrel{2}{0}$

落

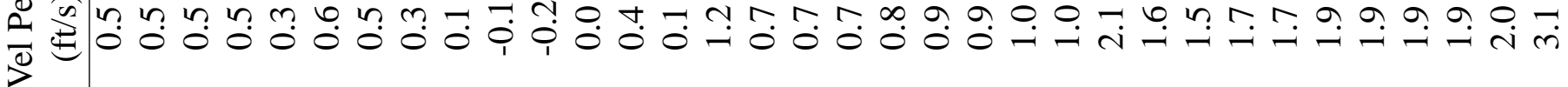

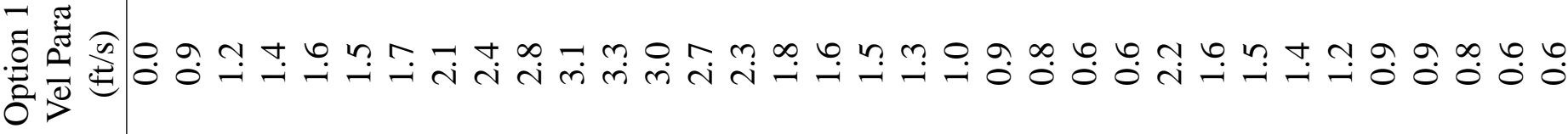

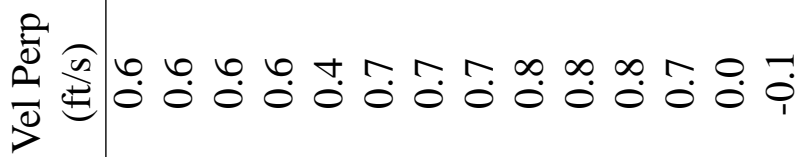

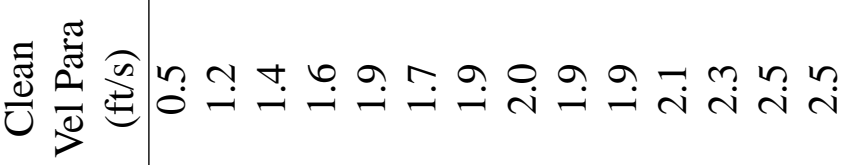

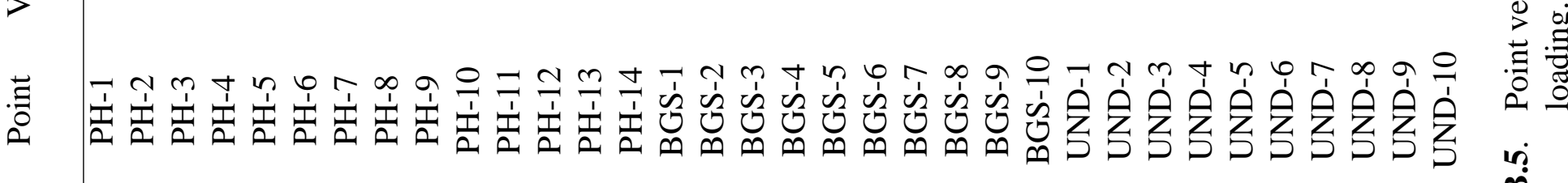




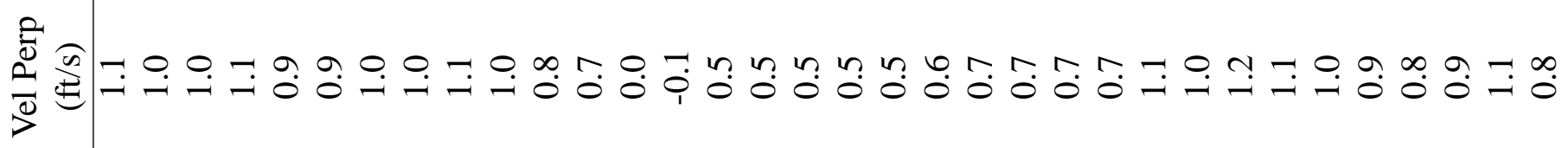

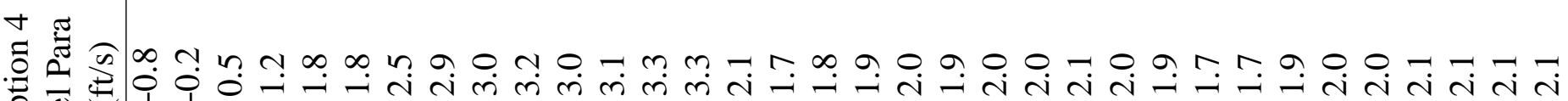

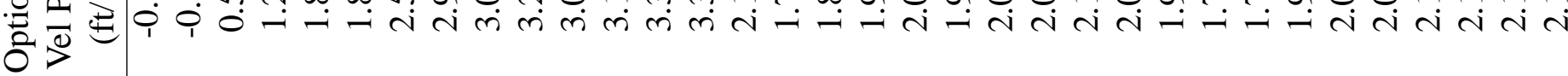

$\stackrel{0}{0}$

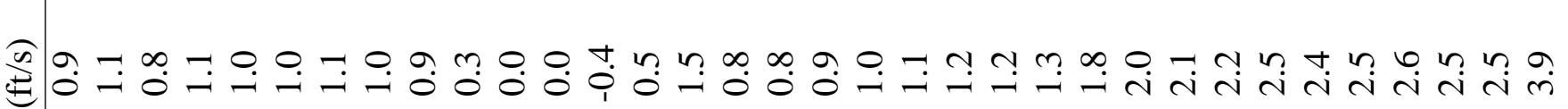

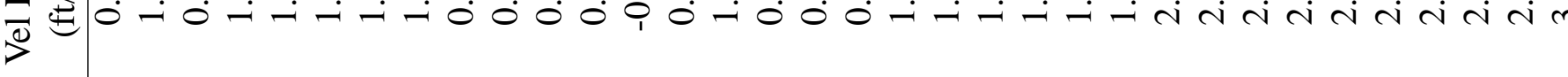

m

흐

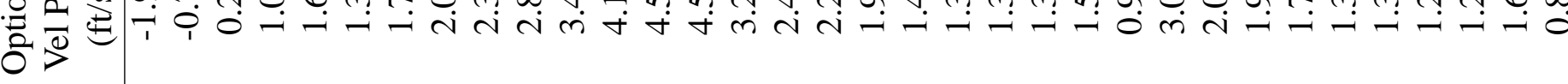

용

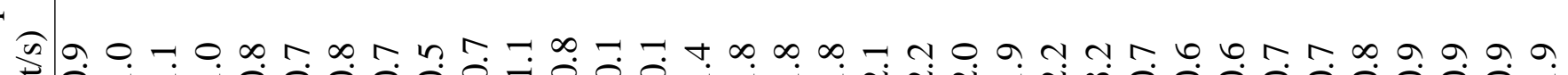

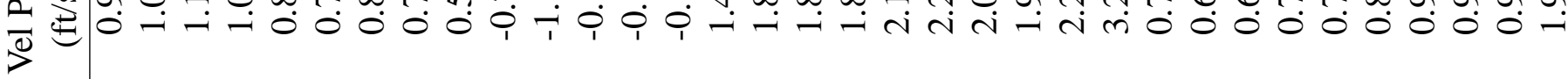

ปี

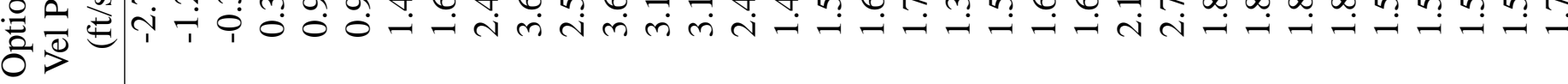

$\stackrel{2}{\bar{d}}$

J

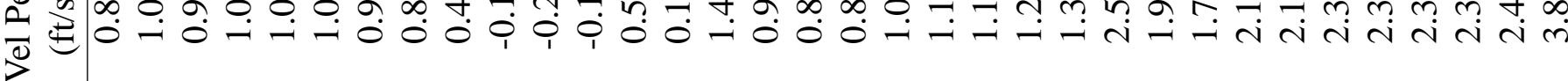

चี

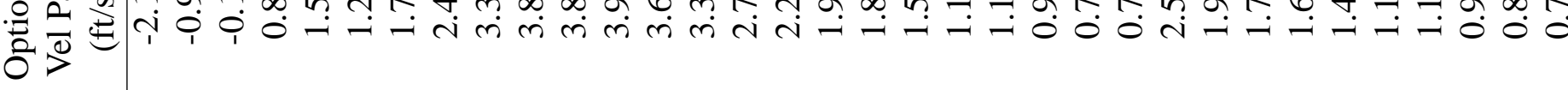

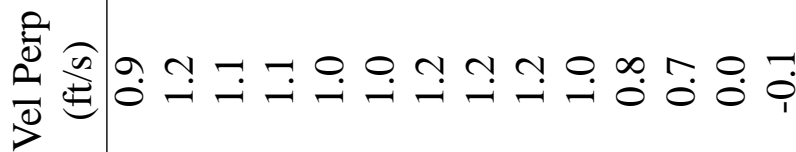

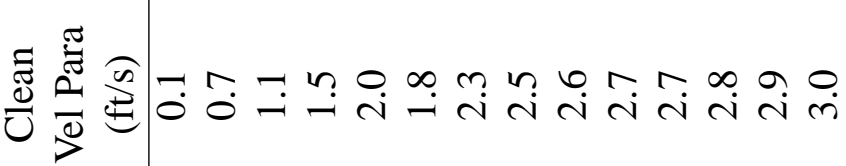

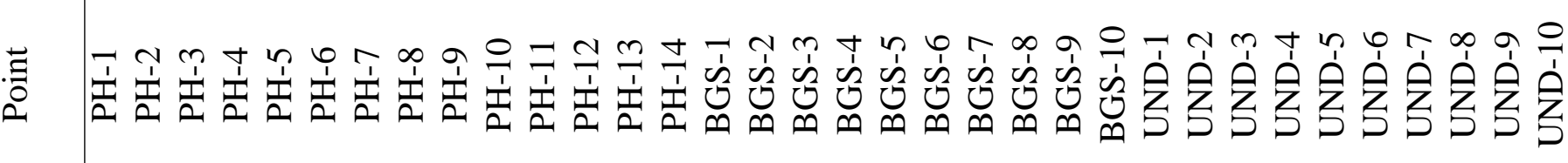


竞

ग)

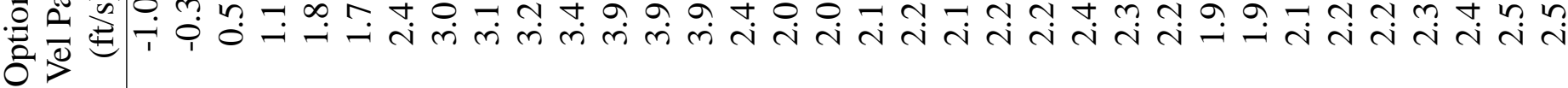

닌

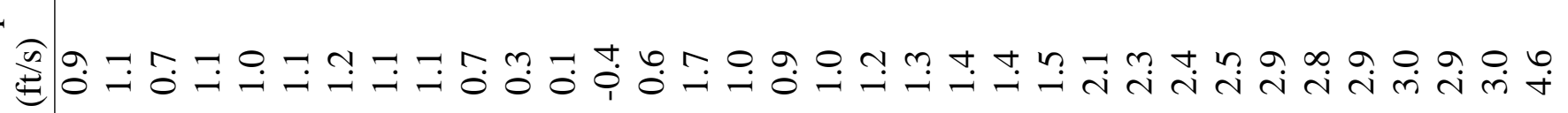

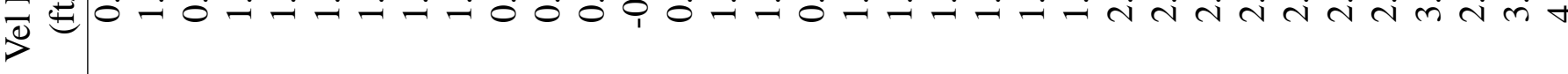

m

.ำ

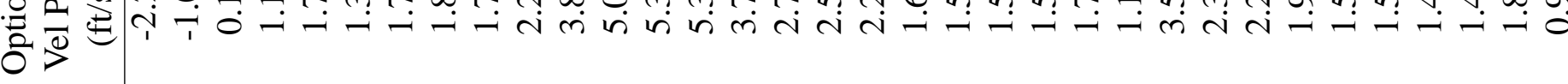

ำ

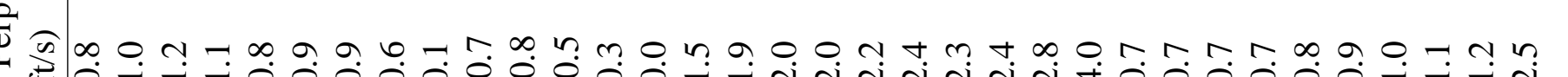

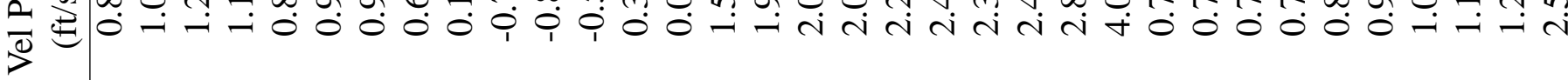

c

กี Ő

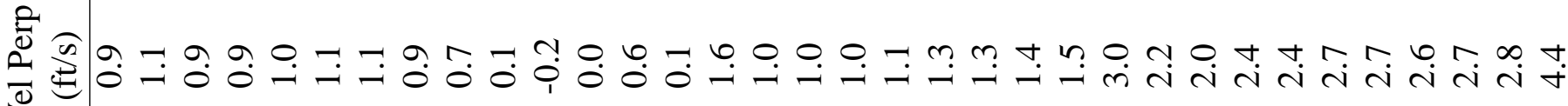

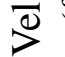



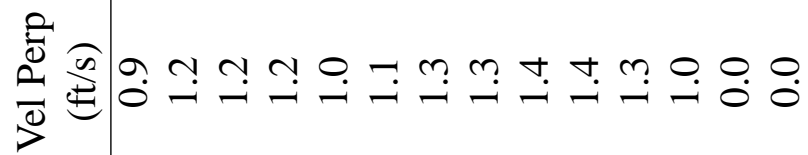

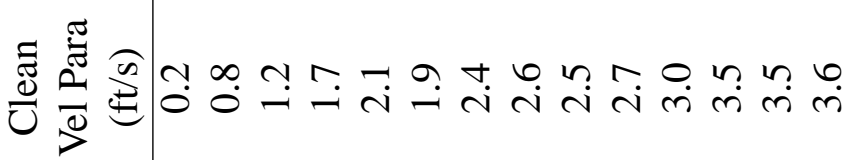

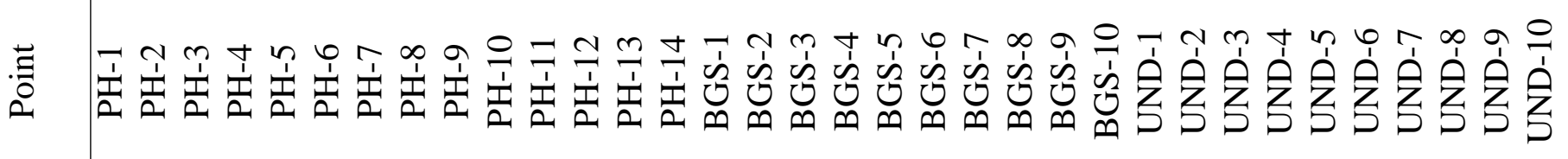





\section{Appendix C}

\section{Option 14 Results}



Appendix C - Option 14 Results

C. 1 


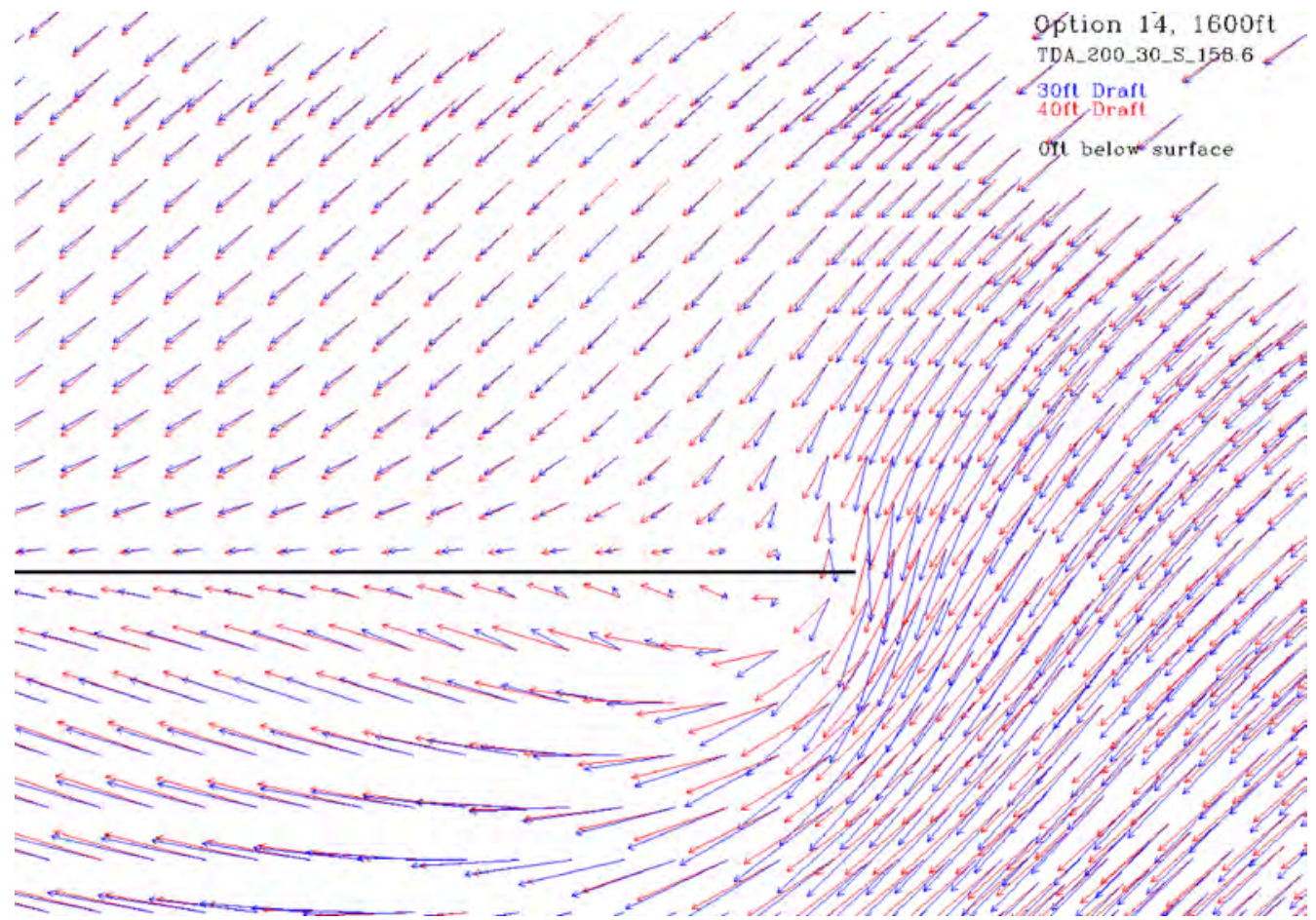

Figure C.1. Comparison of surface vectors for Option 14 Total River $200 \mathrm{kcfs} 30 \%$ spill, standard powerhouse loading for BGS drafts of $40 \mathrm{ft}$ (red) and $30 \mathrm{ft}$ (blue) at the upstream end of the BGS. 


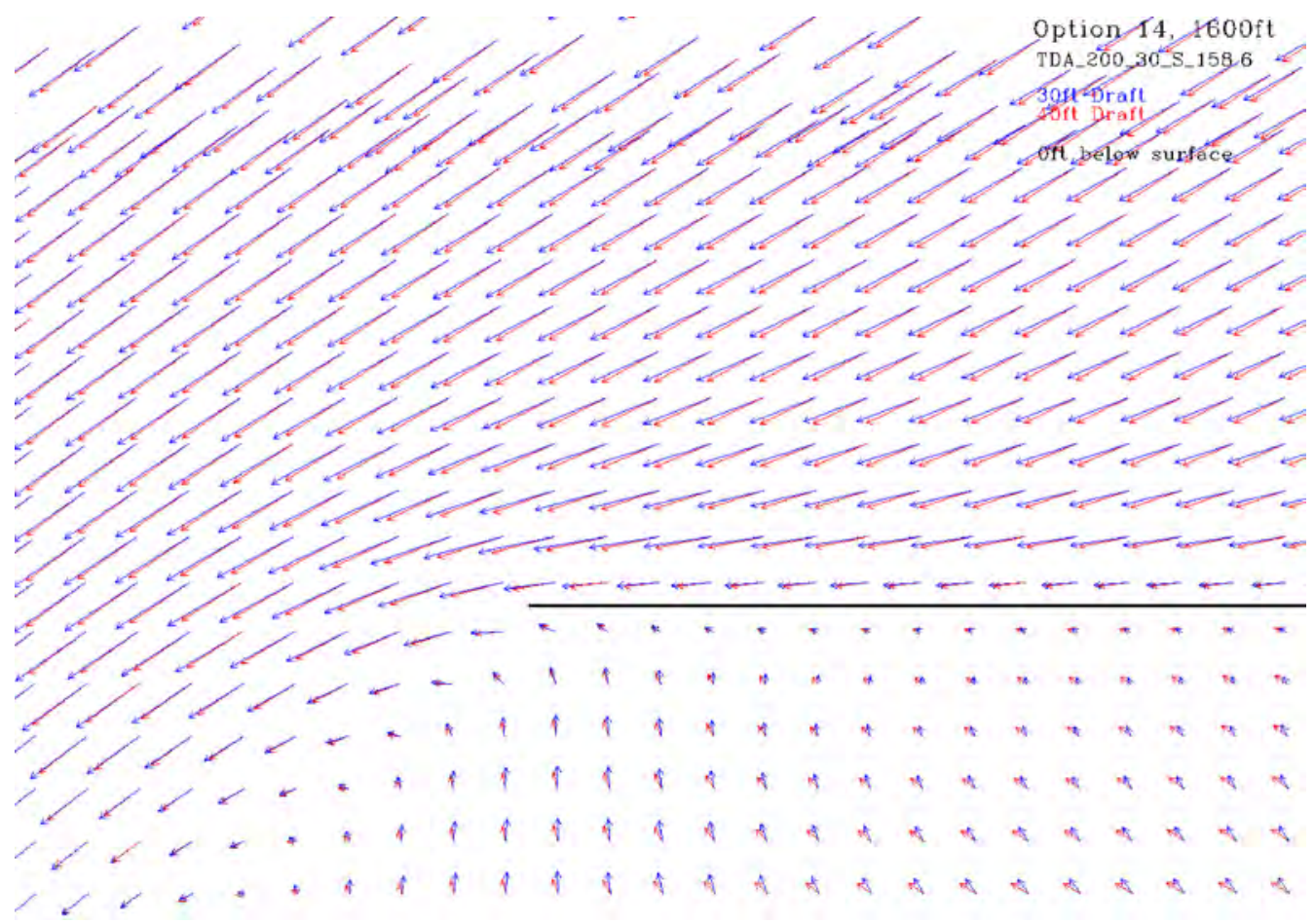

Figure C.2. Comparison of surface vectors for Option 14 Total River $200 \mathrm{kcfs} 30 \%$ spill, standard powerhouse loading for BGS drafts of $40 \mathrm{ft}$ (red) and $30 \mathrm{ft}$ (blue) at the downstream end of the BGS. 


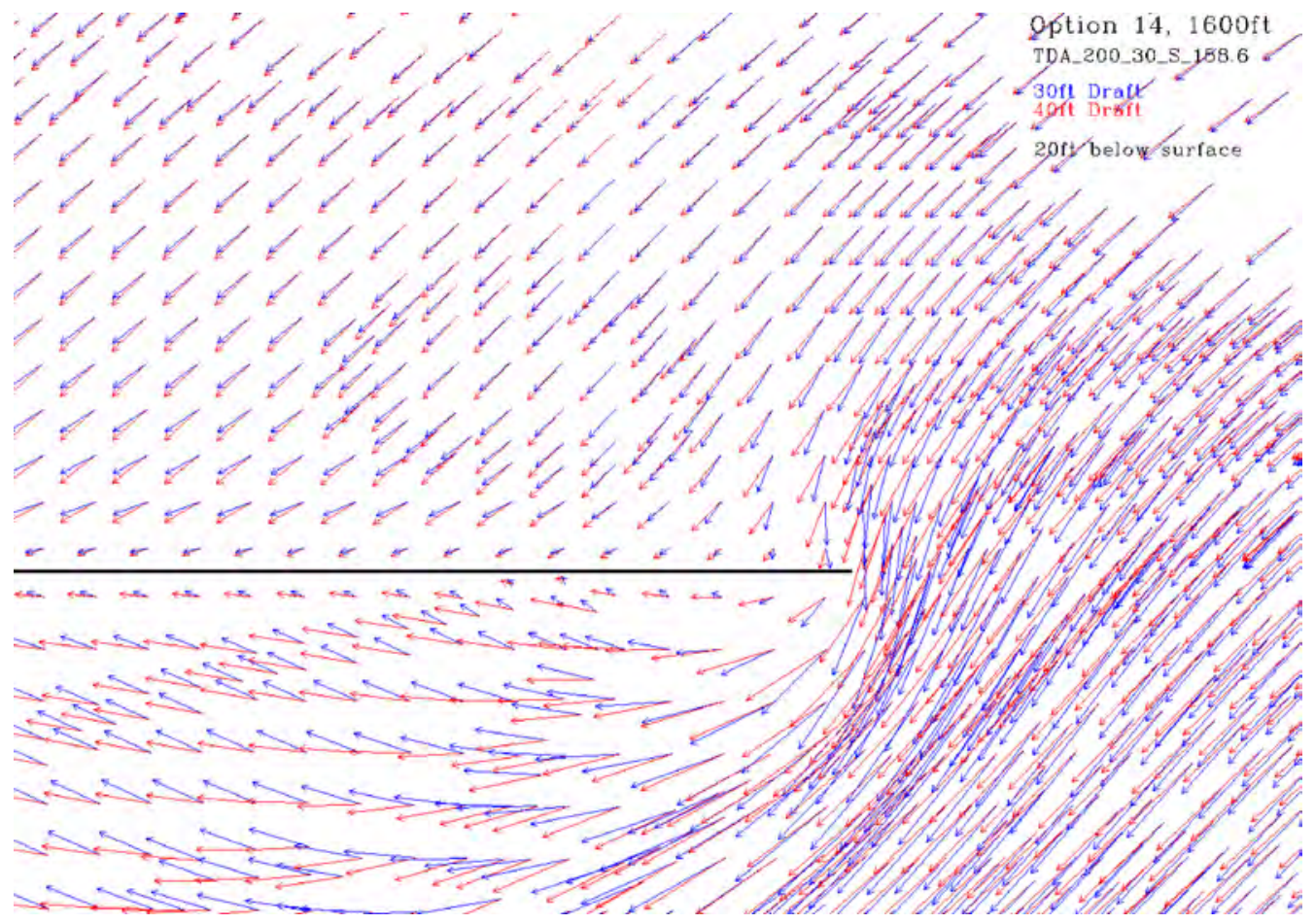

Figure C.3. Comparison of vectors at a $20 \mathrm{ft}$ depth for Option 14 Total River $200 \mathrm{kcfs} 30 \%$ spill, standard powerhouse loading for BGS drafts of $40 \mathrm{ft}$ (red) and $30 \mathrm{ft}$ (blue) at the upstream end of the BGS. 


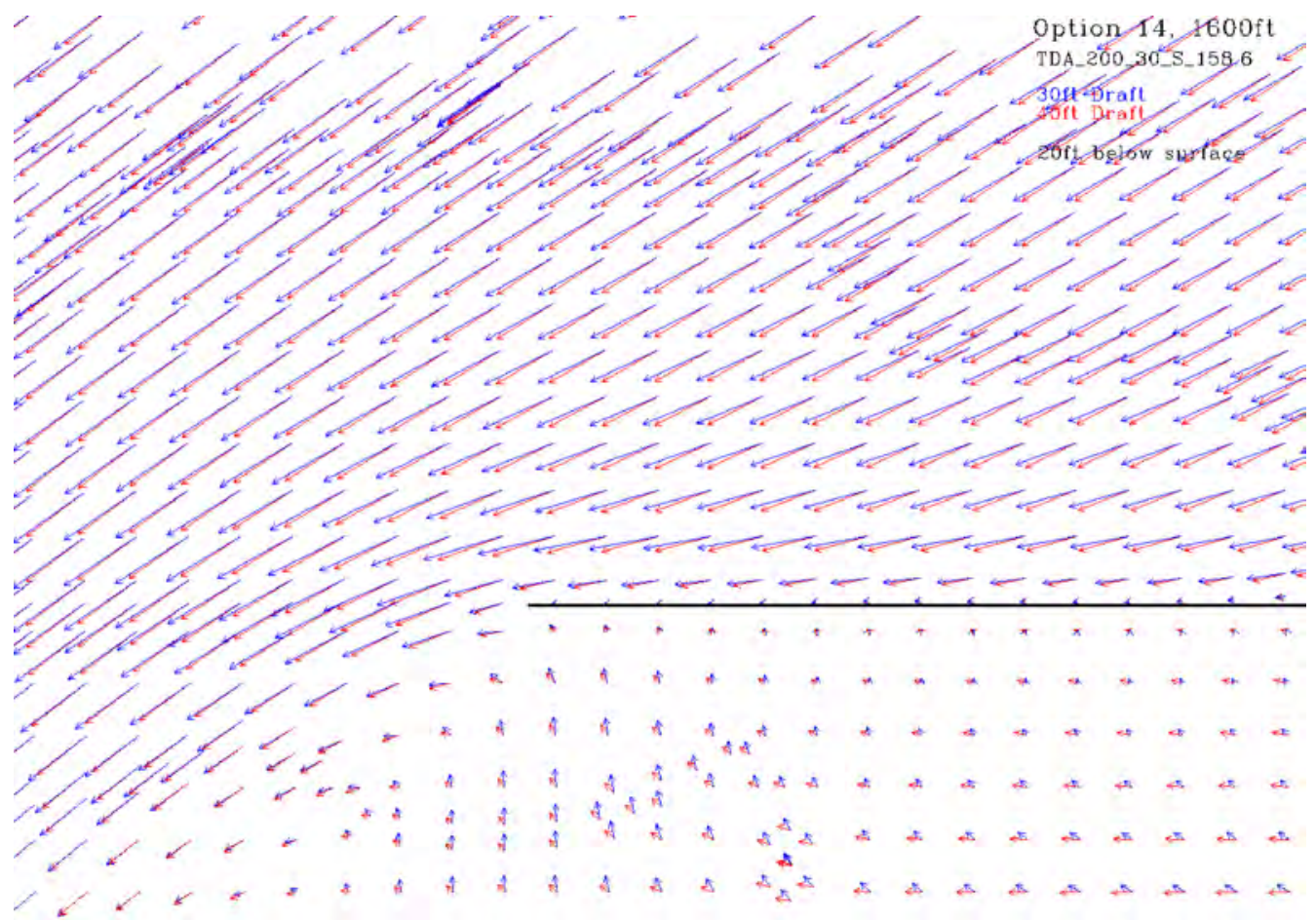

Figure C.4. Comparison of vectors at a $20 \mathrm{ft}$ depth for Option 14 Total River $200 \mathrm{kcfs} 30 \%$ spill, standard powerhouse loading for BGS drafts of $40 \mathrm{ft}$ (red) and $30 \mathrm{ft}$ (blue) at the downstream end of the BGS. 


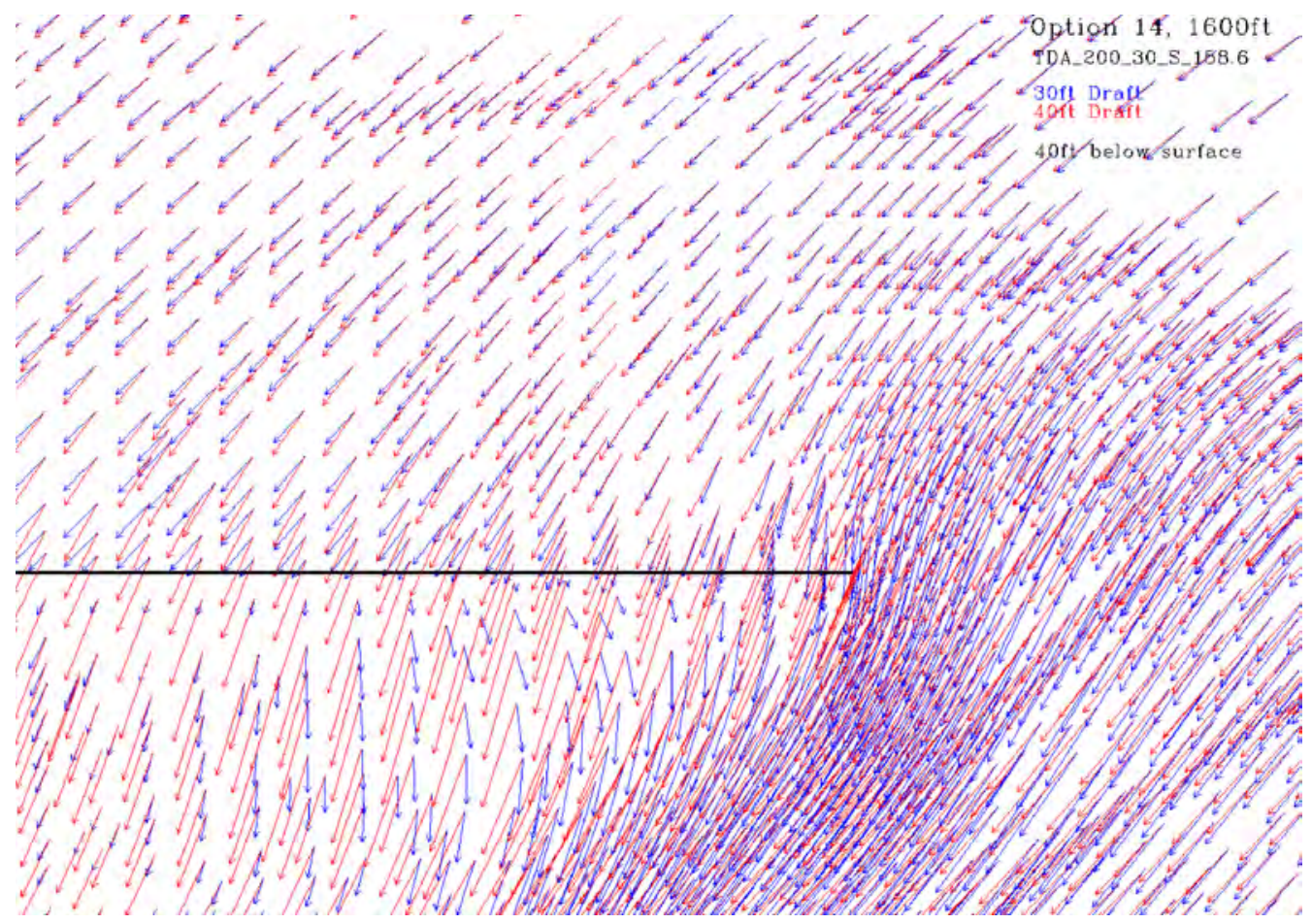

Figure C.5. Comparison of vectors at a $40 \mathrm{ft}$ depth for Option 14 Total River $200 \mathrm{kcfs} 30 \%$ spill, standard powerhouse loading for BGS drafts of $40 \mathrm{ft}$ (red) and $30 \mathrm{ft}$ (blue) at the upstream end of the BGS. 


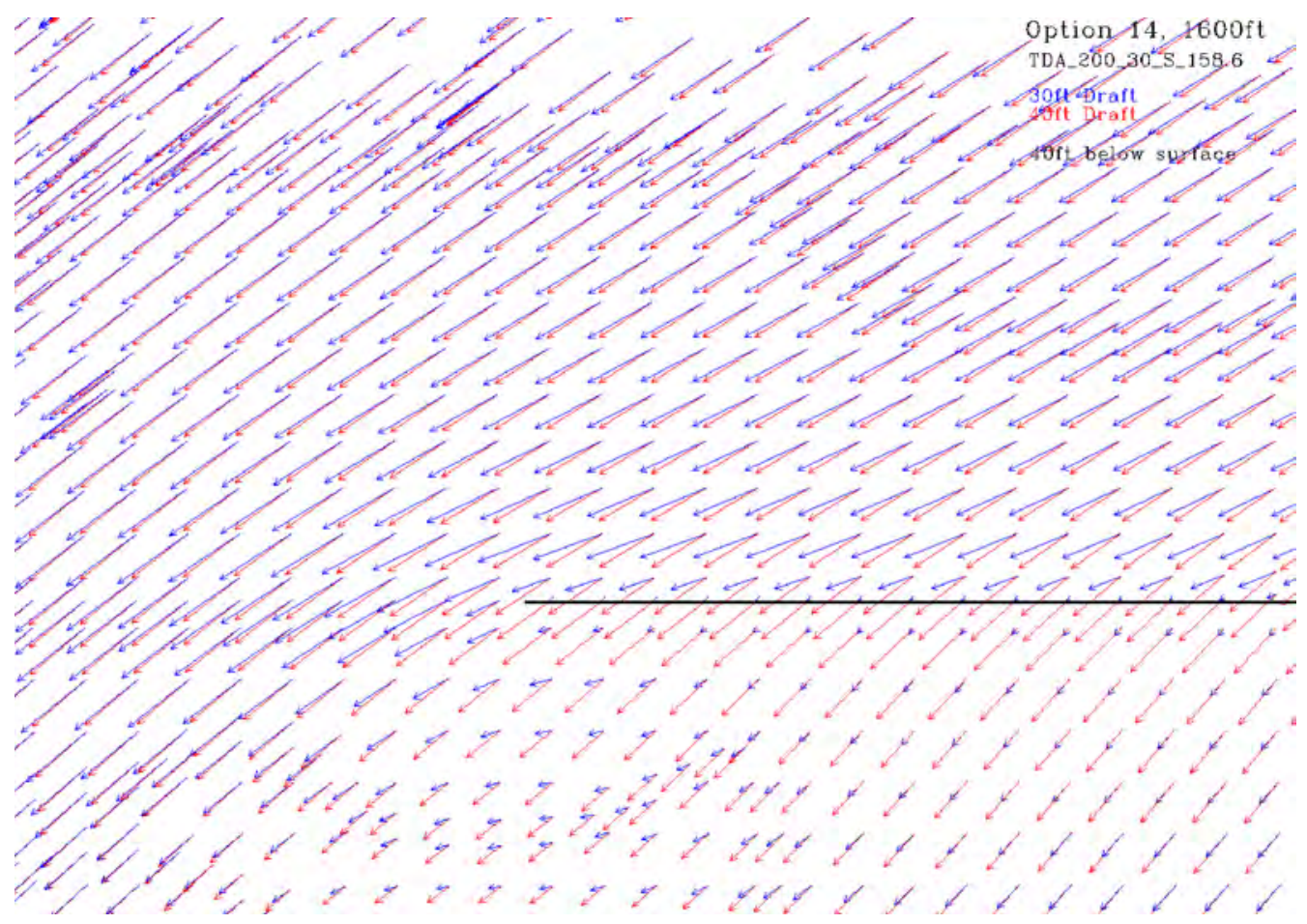

Figure C.6. Comparison of vectors at a $40 \mathrm{ft}$ depth for Option 14 Total River $200 \mathrm{kcfs} 30 \%$ spill, standard powerhouse loading for BGS drafts of $40 \mathrm{ft}$ (red) and $30 \mathrm{ft}$ (blue) at the downstream end of the BGS. 


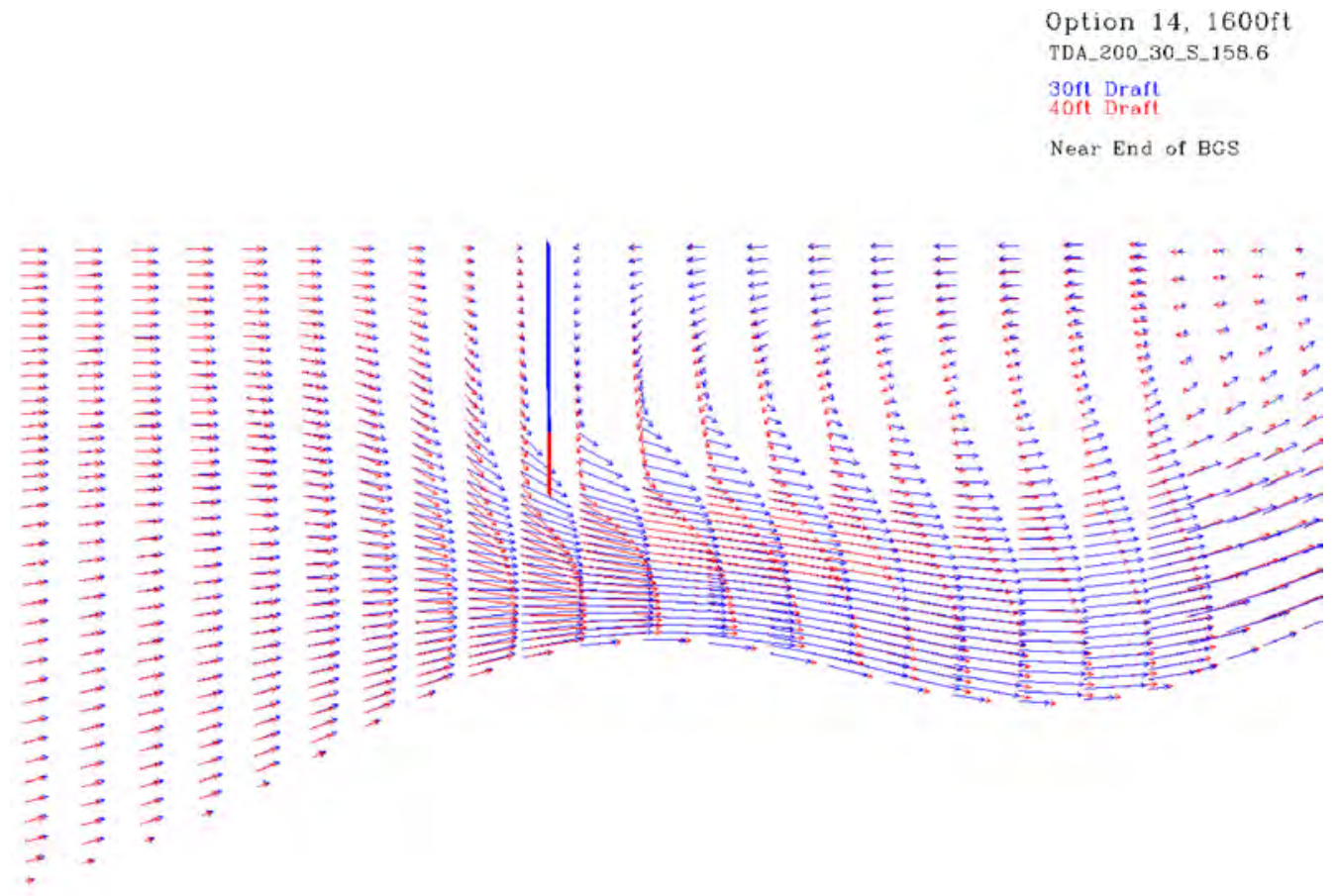

Figure C.7. Comparison for Option 14 Total River $200 \mathrm{kcfs} 30 \%$ spill, vertical slice near the end of the BGS, $40 \mathrm{ft}$ Draft, standard powerhouse loading to the clean forebay.

Option 14,1600 ft

TDA_200_30_S_158.6

$30 \mathrm{ft}$ Draft

Middle of BGS

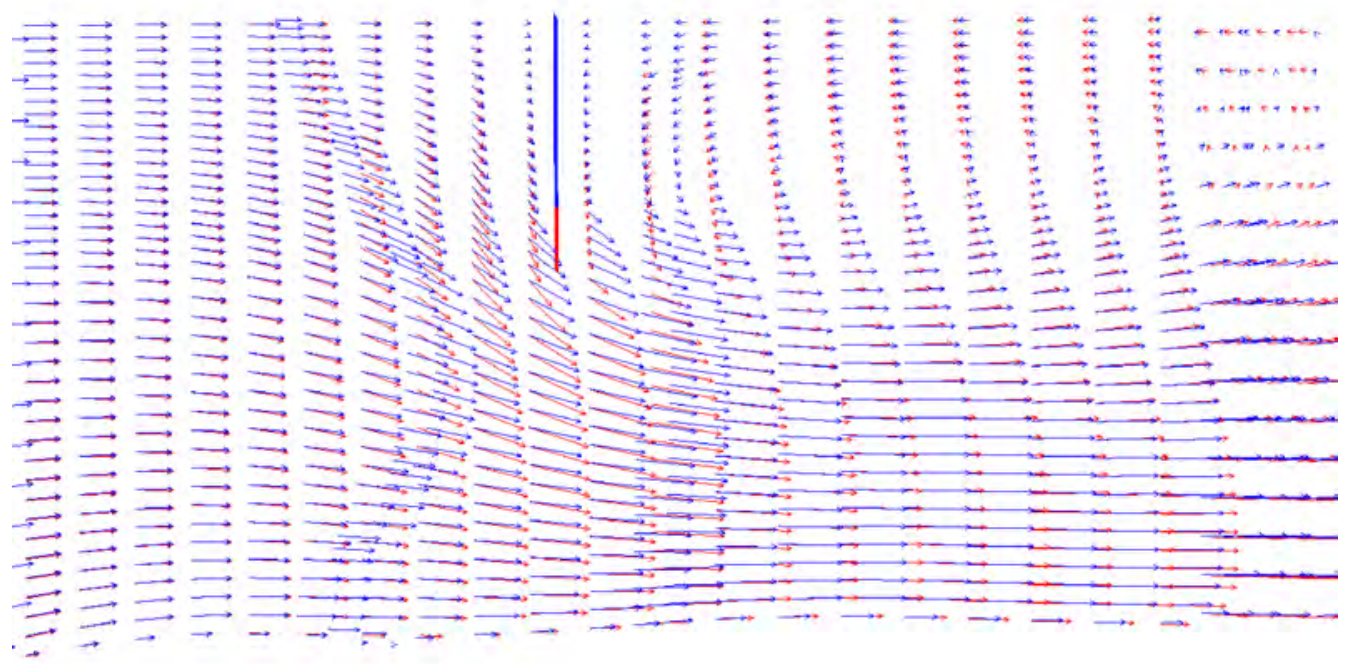

Figure C.8. Comparison for Option 14 Total River $200 \mathrm{kcfs} 30 \%$ spill, vertical slice near the middle of BGS, $40 \mathrm{ft}$ Draft, standard powerhouse loading to the clean forebay. 


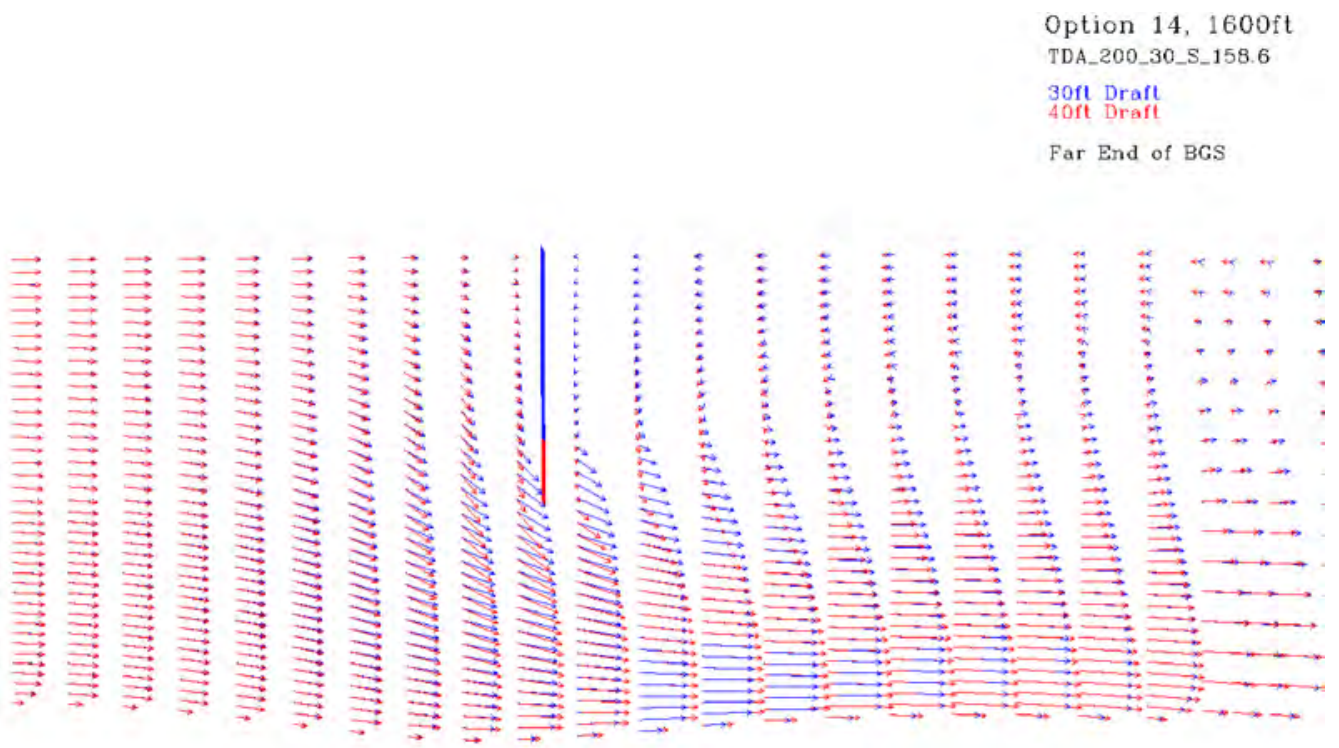

Figure C.9. Comparison for Option 14 Total River $200 \mathrm{kcfs} 30 \%$ spill, vertical slice near the downstream end of BGS, $40 \mathrm{ft}$ Draft, standard powerhouse loading to the clean forebay. 


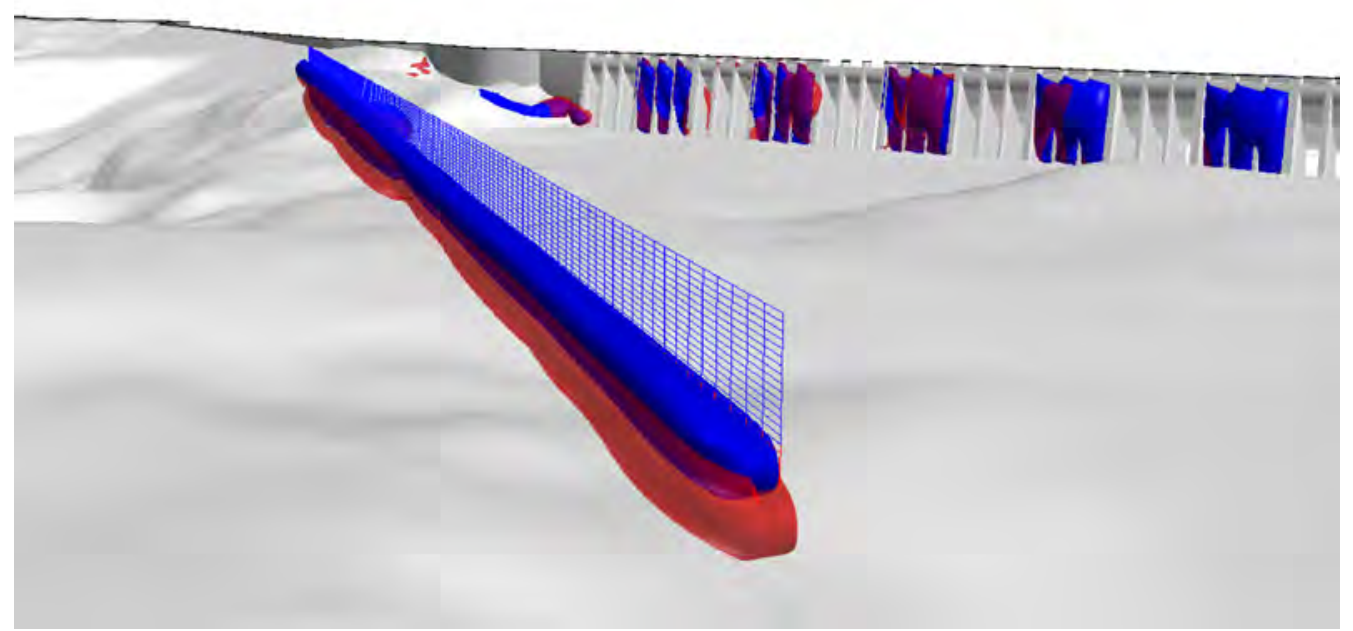

Figure C.10. Comparison for Option 14 Total River $200 \mathrm{kcfs} 30 \%$ spill, $30 \mathrm{ft}$ Draft $40 \mathrm{ft}$ Draft. The isosuface shows where the downward vertical velocities exceed $0.5 \mathrm{ft} / \mathrm{s}$. 


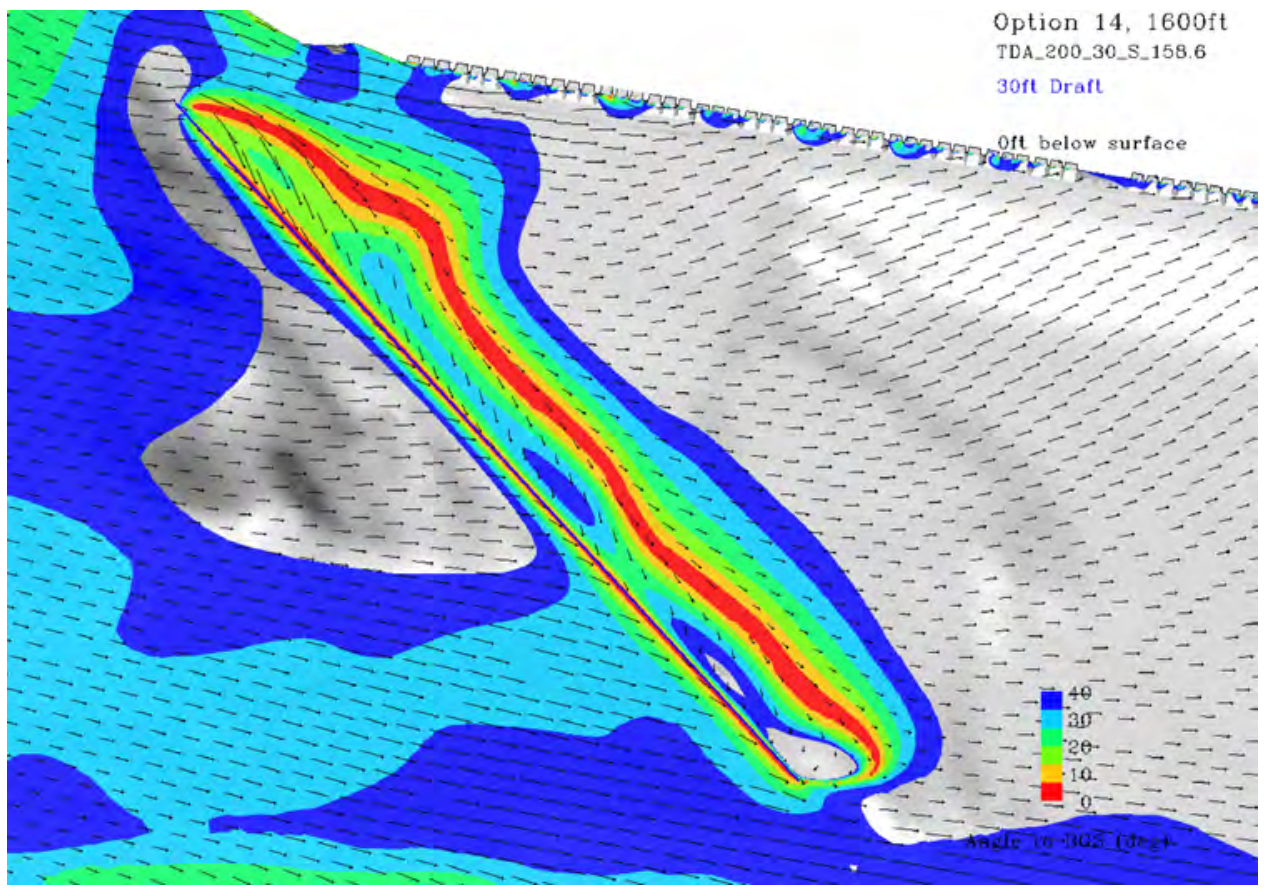

Figure C.11. Angle of flow relative to the BGS at the surface for Option 14 Total River 200 kcfs $30 \%$ spill, $30 \mathrm{ft}$ Draft, standard powerhouse loading. Contours show the angle of the flow relative to the BGS, with the color range from parallel (red) up to 40 degress (blue). Angles greater than 40 degrees are not contoured. 


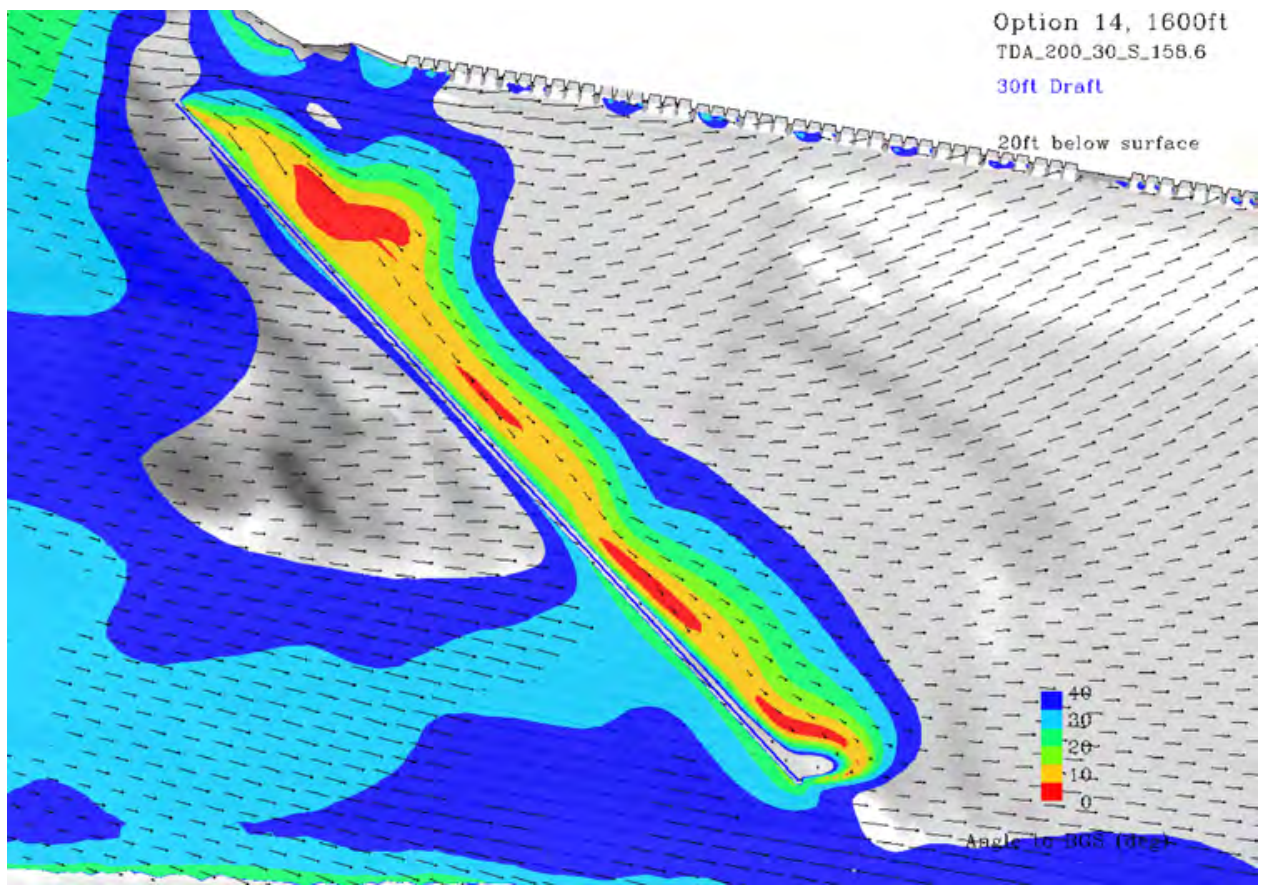

Figure C.12. Angle of flow relative to the BGS at a depth of $20 \mathrm{ft}$. Option 14 Total River 200 $\mathrm{kcfs} 30 \%$ spill, $30 \mathrm{ft}$ Draft, standard powerhouse loading. Contours show the angle of the flow relative to the BGS, with the color range from parallel (red) up to 40 degress (blue). Angles greater than 40 degrees are not contoured. 


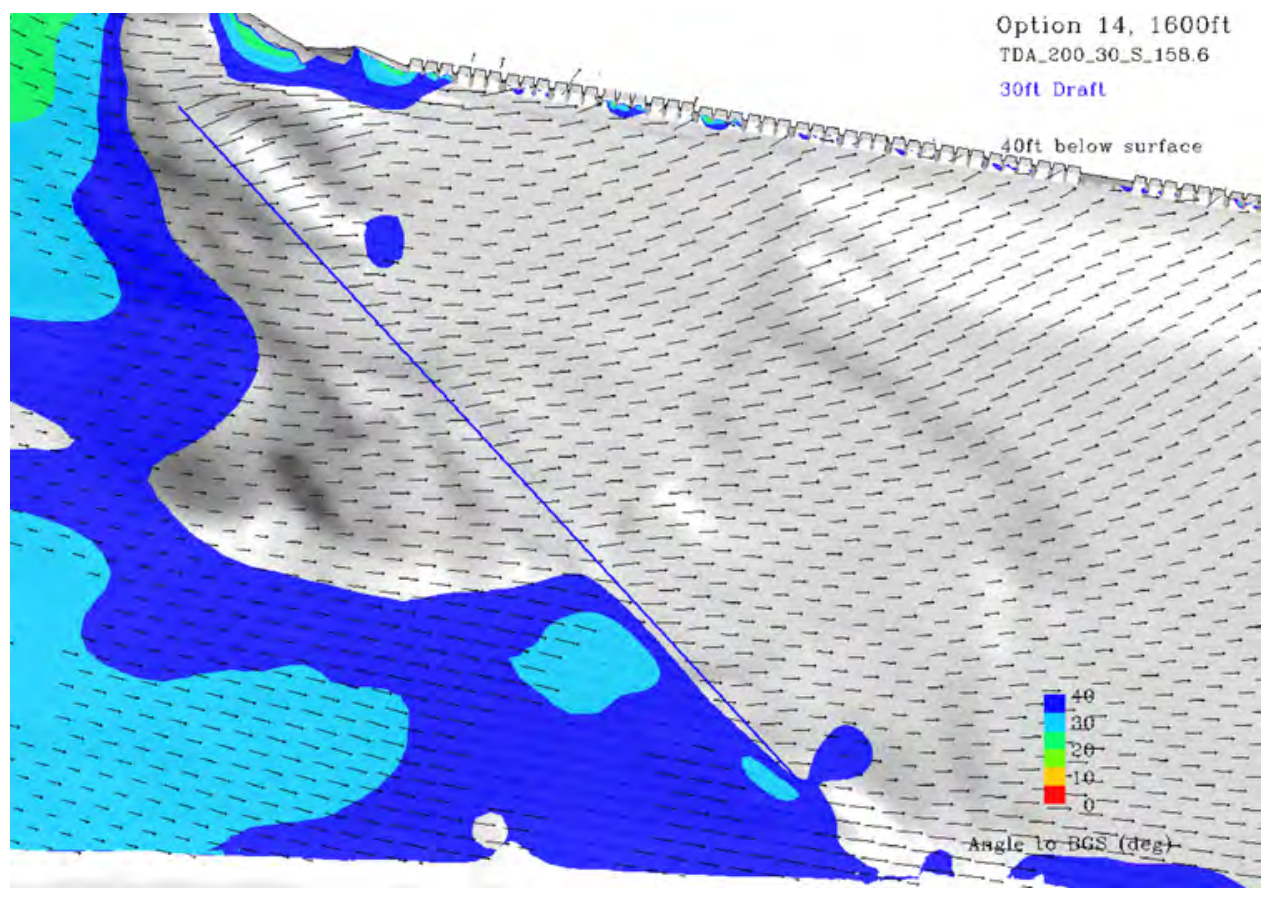

Figure C.13. Angle of flow relative to the BGS at a depth of $40 \mathrm{ft}$ for Option 14 Total River $200 \mathrm{kcfs} 30 \%$ spill, $30 \mathrm{ft}$ Draft, standard powerhouse loading. Contours show the angle of the flow relative to the BGS, with the color range from parallel (red) up to 40 degress (blue). Angles greater than 40 degrees are not contoured. 


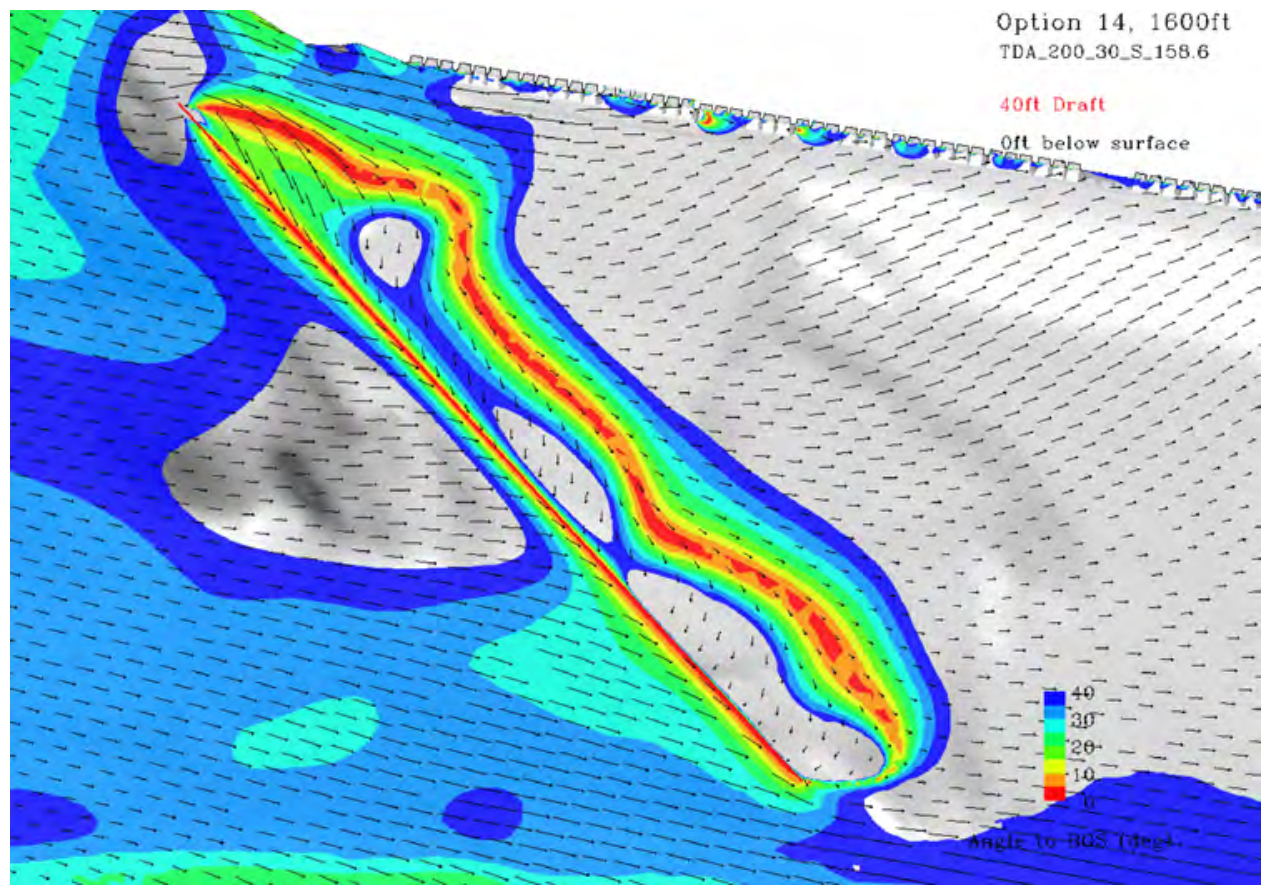

Figure C.14. Angle of flow relative to the BGS at the surface for Option 14 Total River 200 kcfs 30\% spill, $40 \mathrm{ft}$ Draft,standard powerhouse loading. Contours show the angle of the flow relative to the BGS, with the color range from parallel (red) up to 40 degress (blue). Angles greater than 40 degrees are not contoured. 


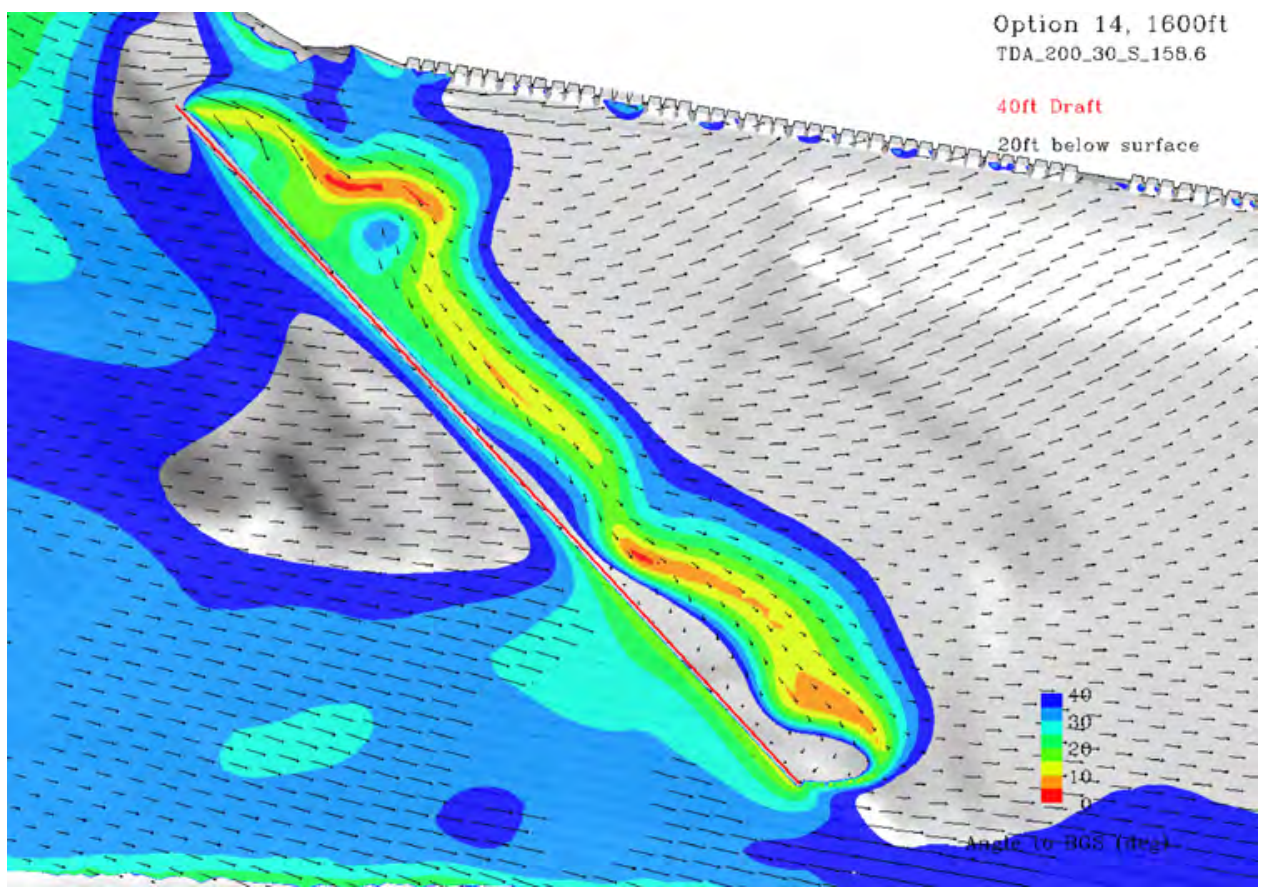

Figure C.15. Angle of flow relative to the BGS at a depth of $20 \mathrm{ft}$ for Option 14 Total River 200 kcfs $30 \%$ spill, $40 \mathrm{ft}$ Draft, $20 \mathrm{ft}$ below surface, standard powerhouse loading.

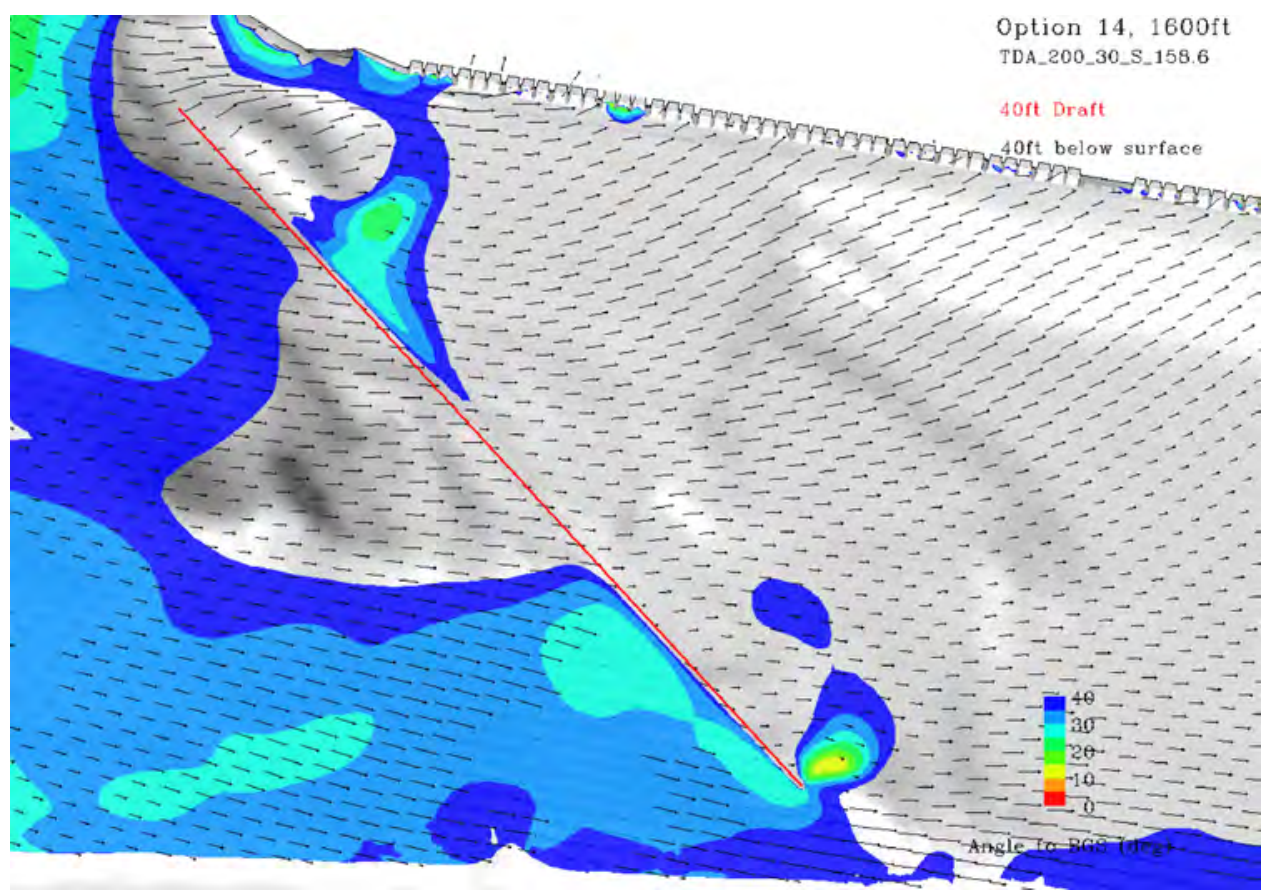

Figure C.16. Angle of flow relative to the BGS at a depth of $40 \mathrm{ft}$ for Option 14 Total River $200 \mathrm{kcfs} 30 \%$ spill, $40 \mathrm{ft}$ Draft, standard powerhouse loading. 


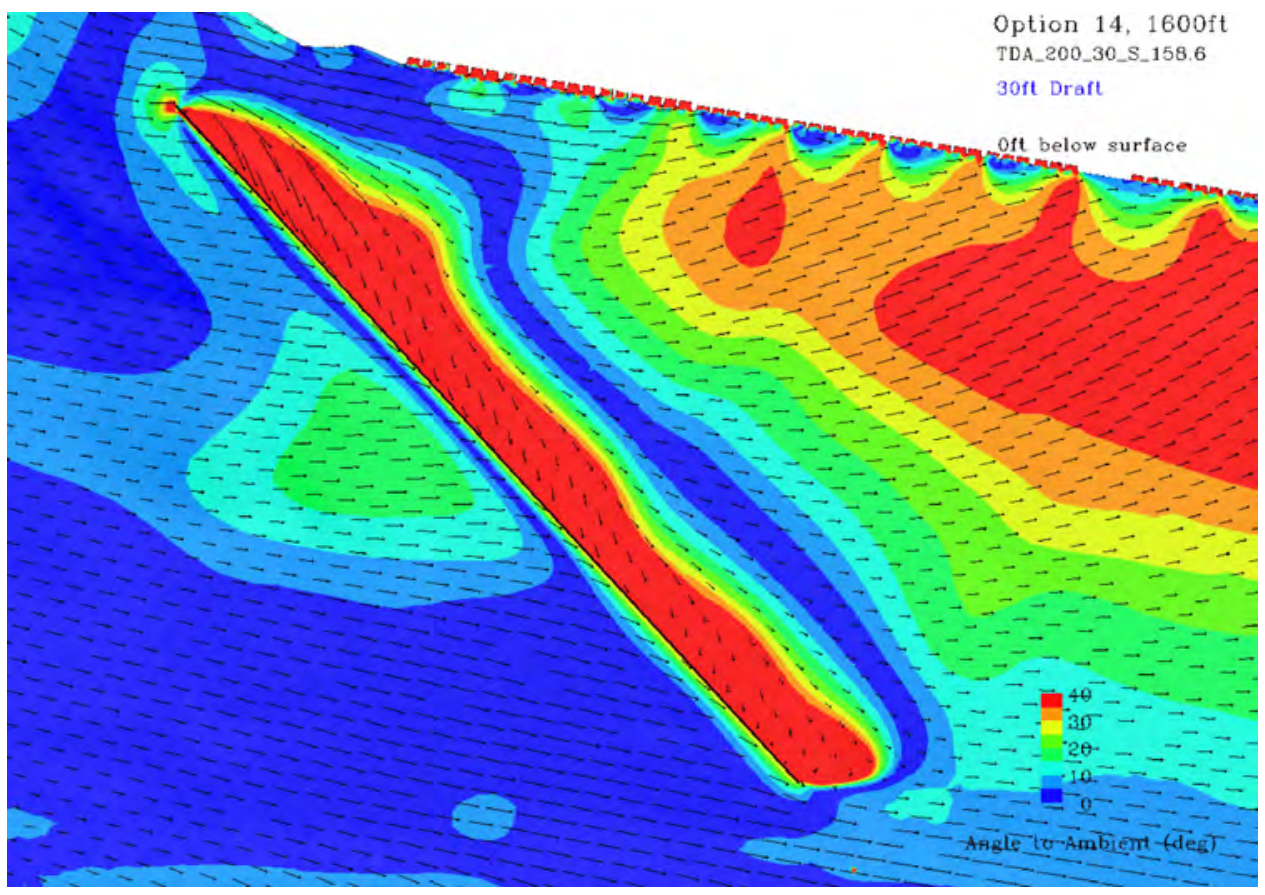

Figure C.17. Angle of flow relative to the clean forebay (ambient) at the surface for Option 14 Total River $200 \mathrm{kcfs} 30 \%$ spill, $30 \mathrm{ft}$ Draft, standard powerhouse loading. 


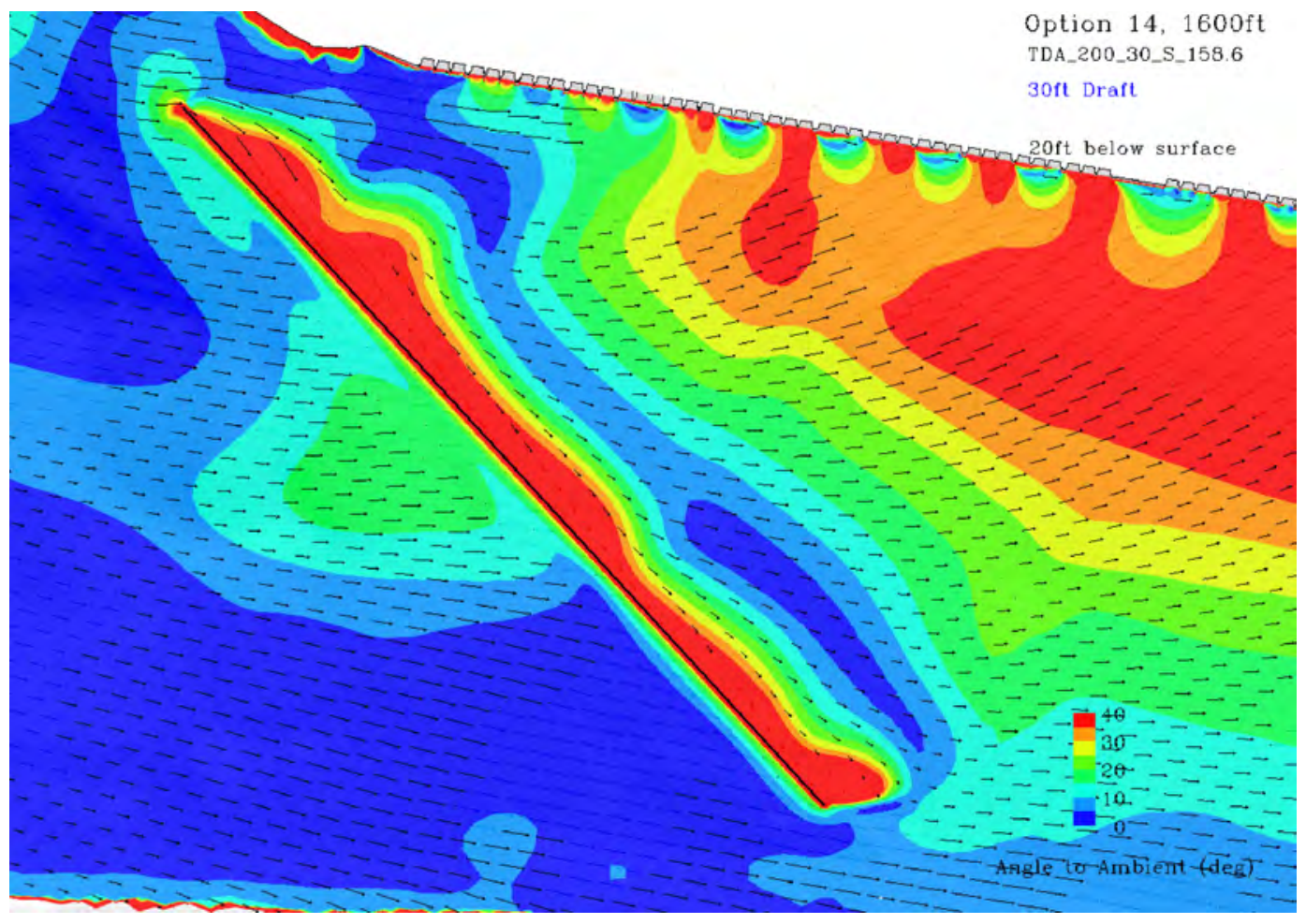

Figure C.18. Angle of flow relative to the clean forebay (ambient) at a depth of $20 \mathrm{ft}$ for Option 14 Total River $200 \mathrm{kcfs} 30 \%$ spill, $30 \mathrm{ft}$ Draft, standard powerhouse loading. 


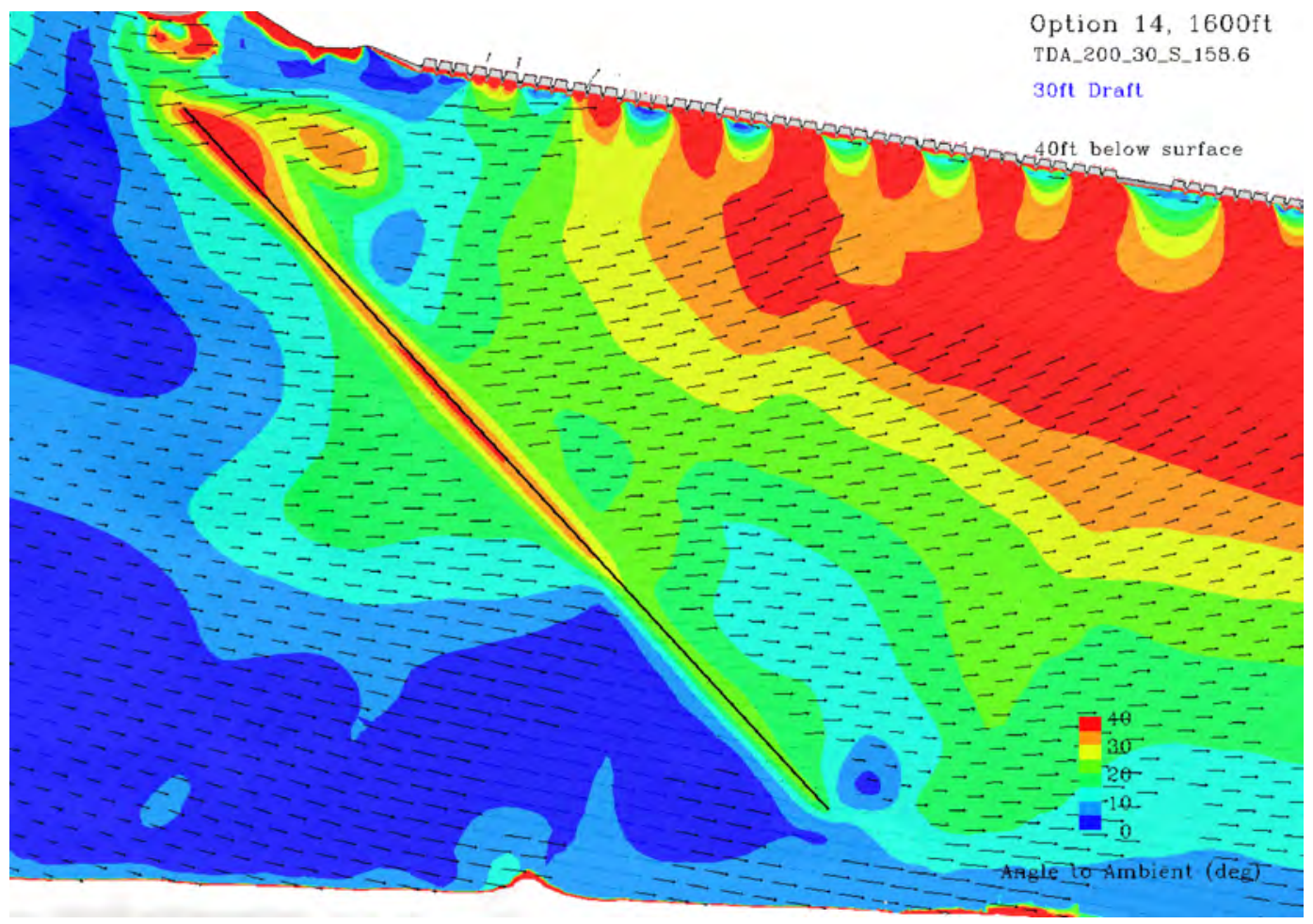

Figure C.19. Angle of flow relative to the clean forebay (ambient) at a depth of $40 \mathrm{ft}$ for Option 14 Total River $200 \mathrm{kcfs} 30 \%$ spill, $30 \mathrm{ft}$ Draft, standard powerhouse loading. 


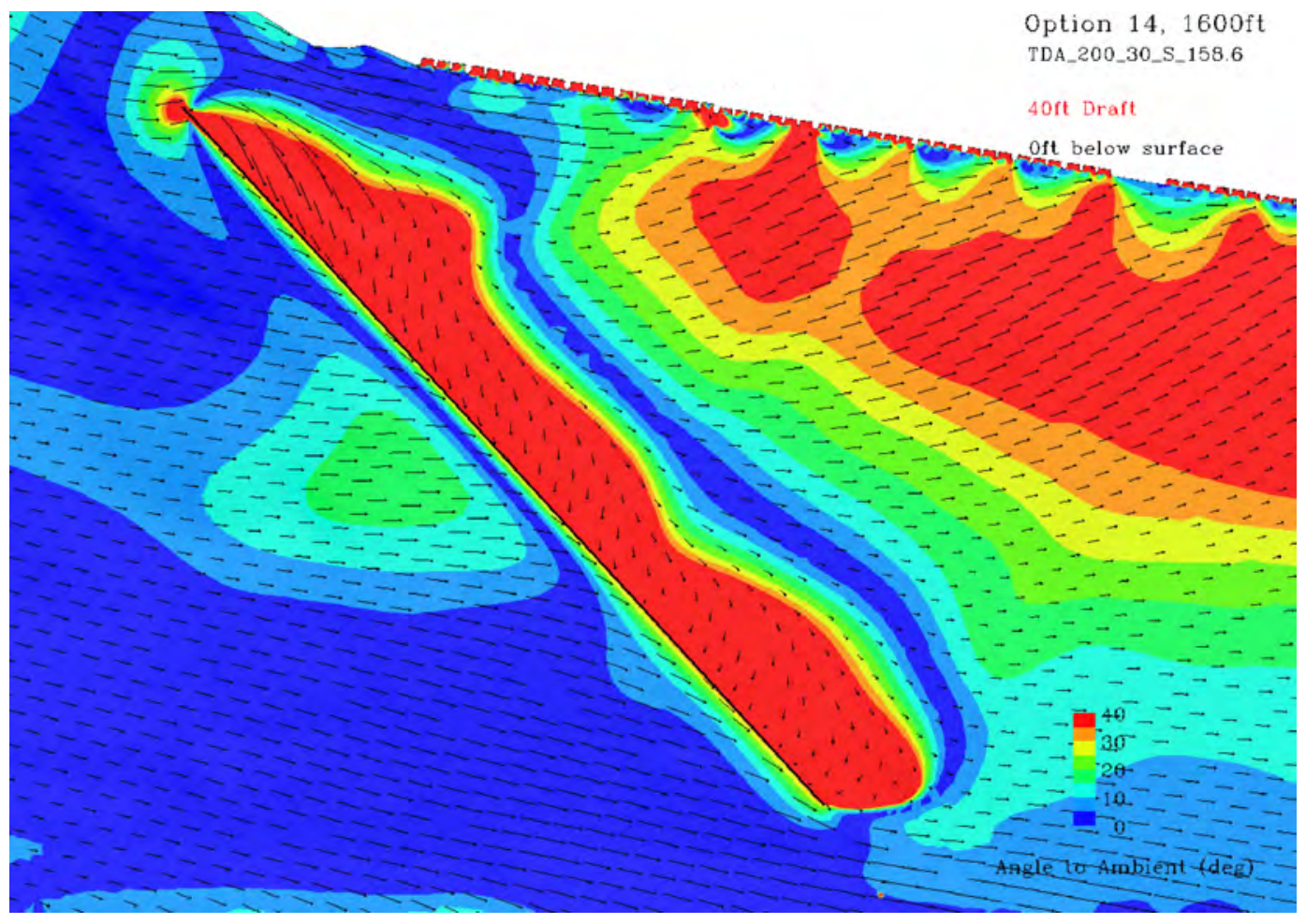

Figure C.20. Angle of flow relative to the clean forebay (ambient) at the surface for Option 14 Total River $200 \mathrm{kcfs} 30 \%$ spill, $40 \mathrm{ft}$ Draft, standard powerhouse loading. 


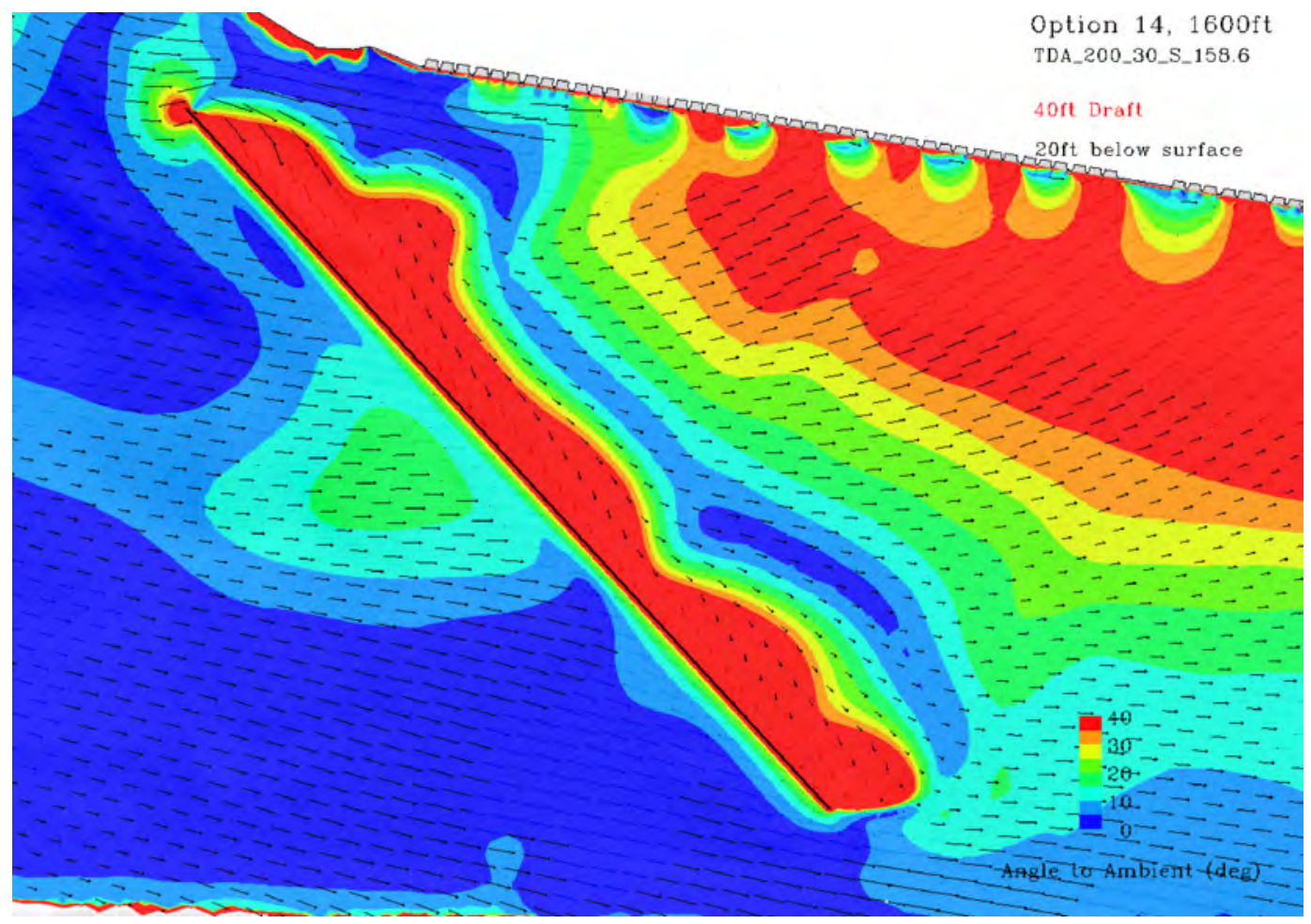

Figure C.21. Angle of flow relative to the clean forebay (ambient) at a depth of $20 \mathrm{ft}$ for Option 14 Total River $200 \mathrm{kcfs} 30 \%$ spill, $40 \mathrm{ft}$ Draft, standard powerhouse loading. 


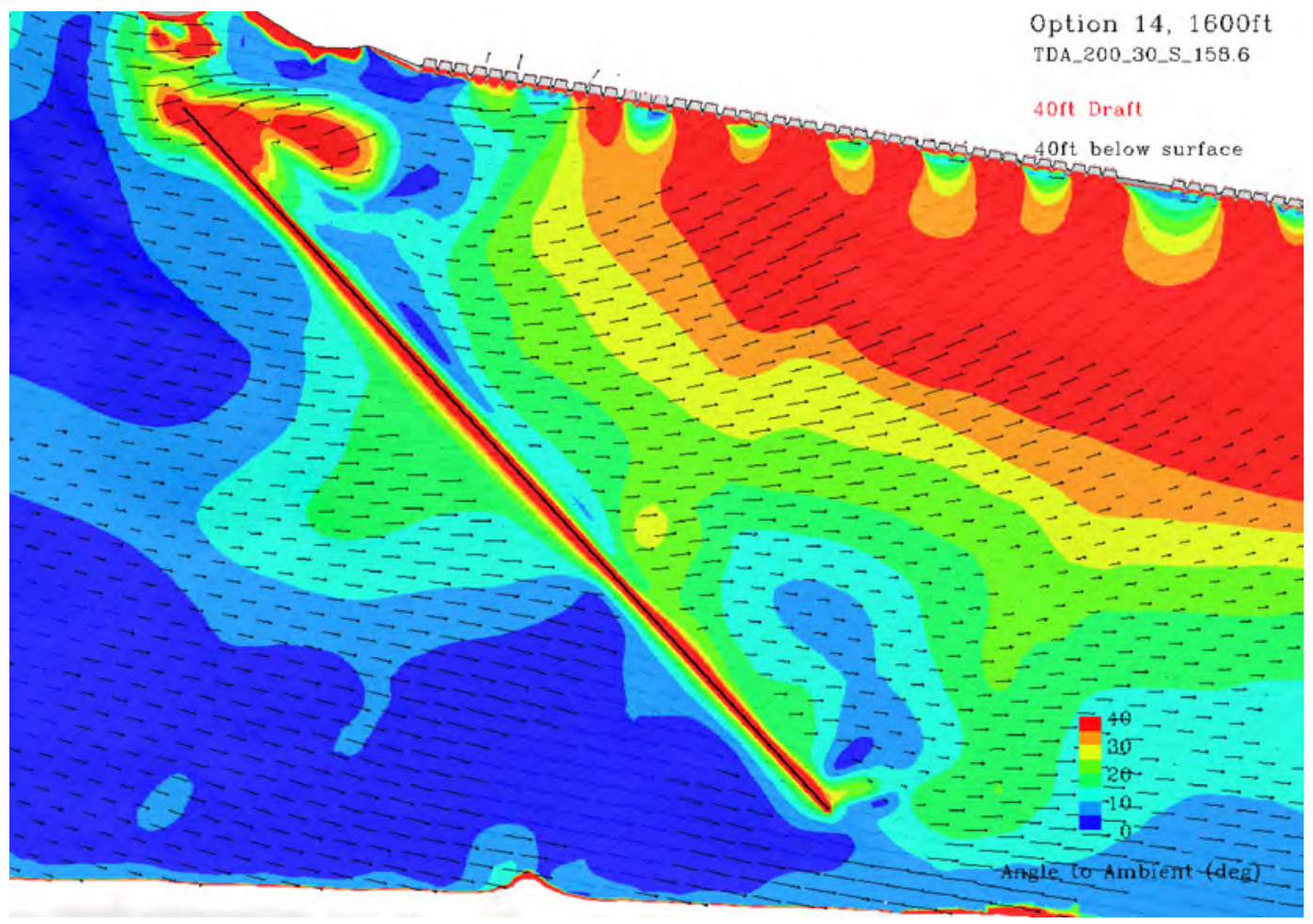

Figure C.22. Angle of flow relative to the clean forebay (ambient) at a depth of $40 \mathrm{ft}$ for Option 14 Total River $200 \mathrm{kcfs} 30 \%$ spill, $40 \mathrm{ft}$ Draft, standard powerhouse loading. 



\section{Appendix D}

Option 14 Navigation Runs and Miscellaneous Runs 

Appendix D - Option 14 Navigation Runs and Miscellaneous Runs

D. 1 


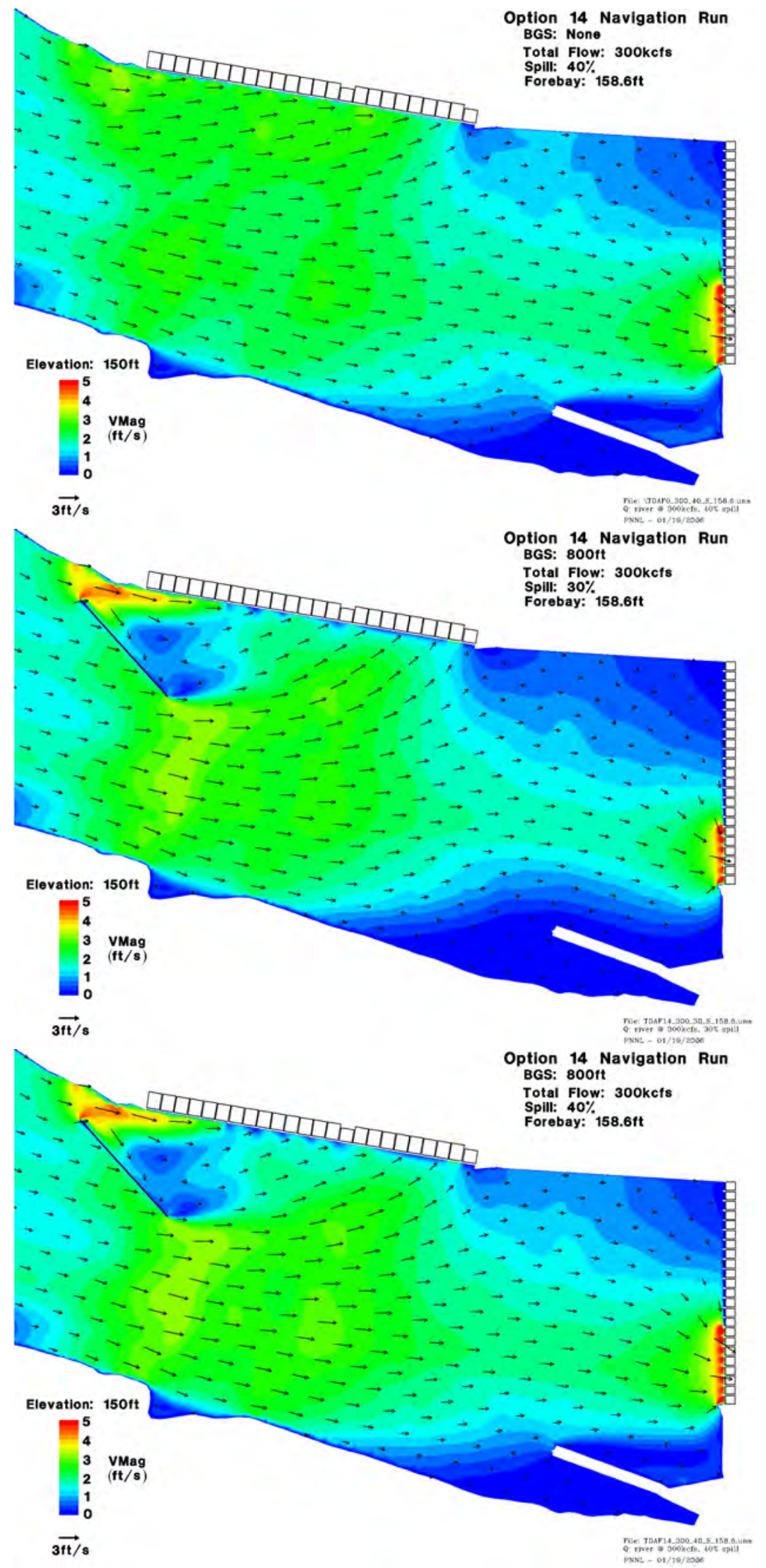

Figure D.1. Simulation results for a Total River of $300 \mathrm{kcfs}$ for the clean forebay (top), $30 \%$ spill with an $800-f t$ BGS (middle) and $40 \%$ spill with a $800-f t$ BGS (bottom).

D.2 


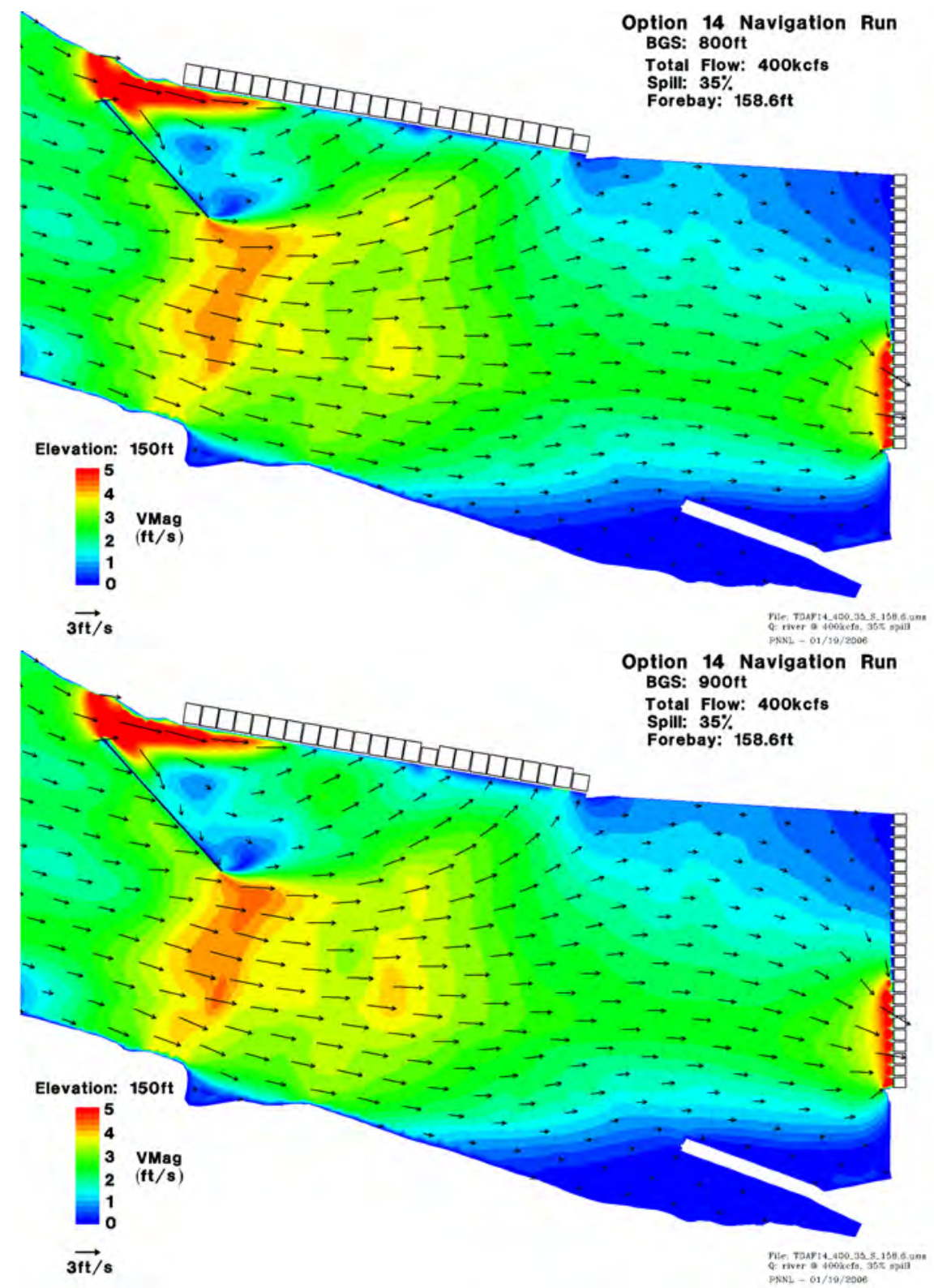

Figure D.2. The BGS simulation results for a Total River of $400 \mathrm{kcfs}$ with $35 \%$ spill for an 800-ft length (top) and 900-ft length (bottom). 

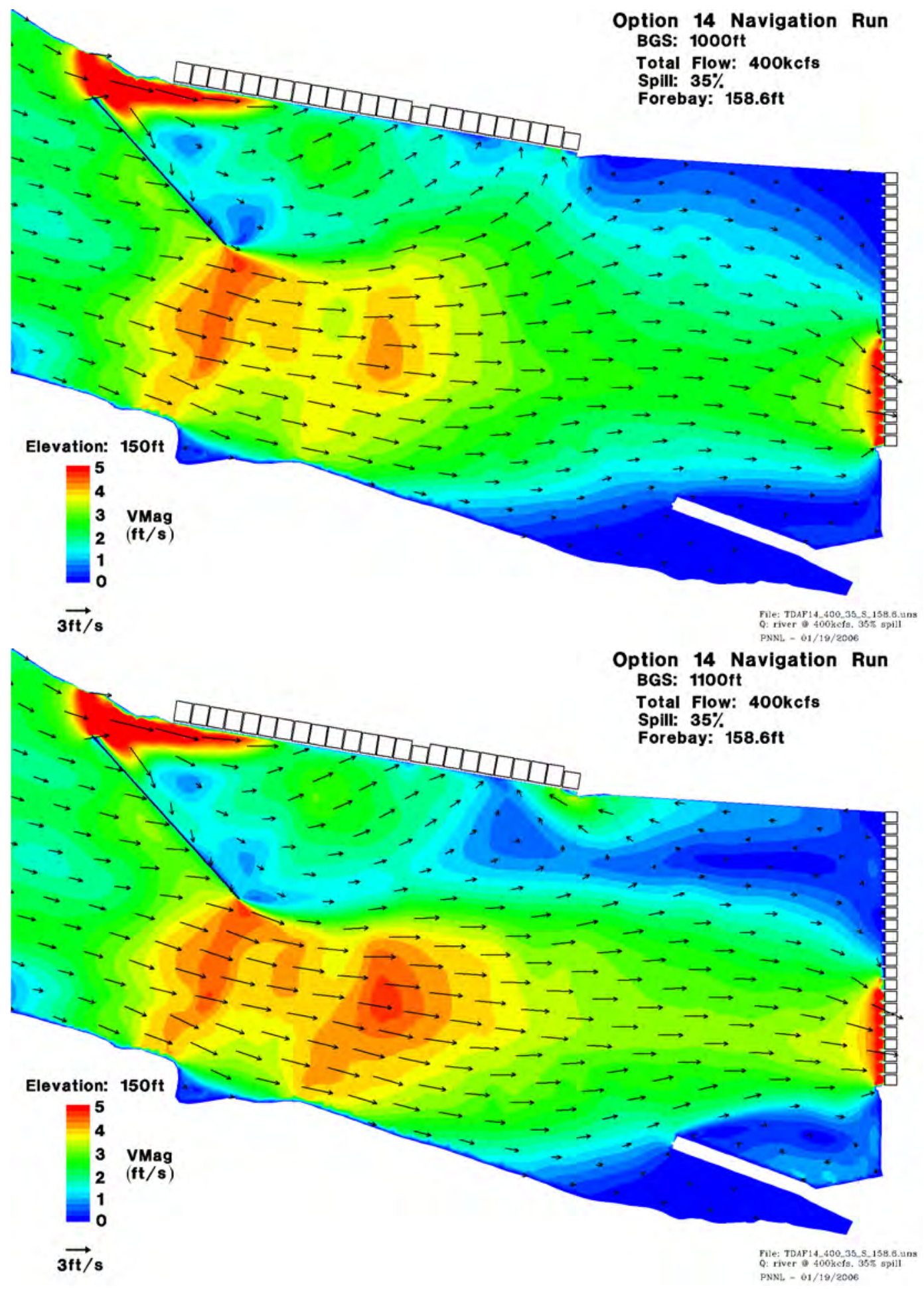

Figure D.3. The 800-ft BGS simulation results for a Total River of $400 \mathrm{kcfs}$ with $35 \%$ spill for a 1000-ft length (top), 1100-ft length (bottom). 


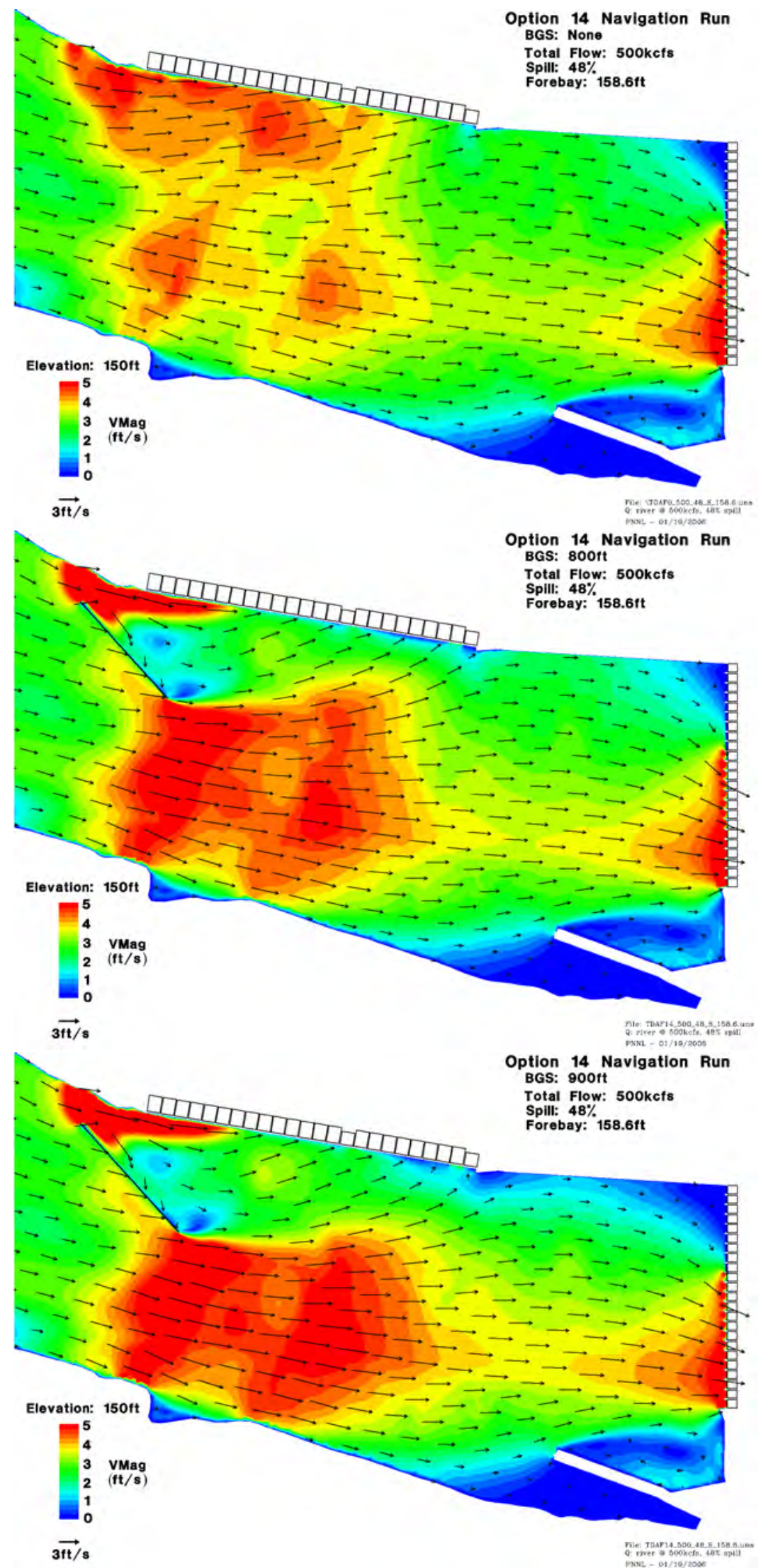

Figure D.4. The BGS simulation results for a Total River of $500 \mathrm{kcfs}$ with $48 \%$ spill for a clean forebay (top), 800-ft length (middle) and 900-ft length (bottom). 

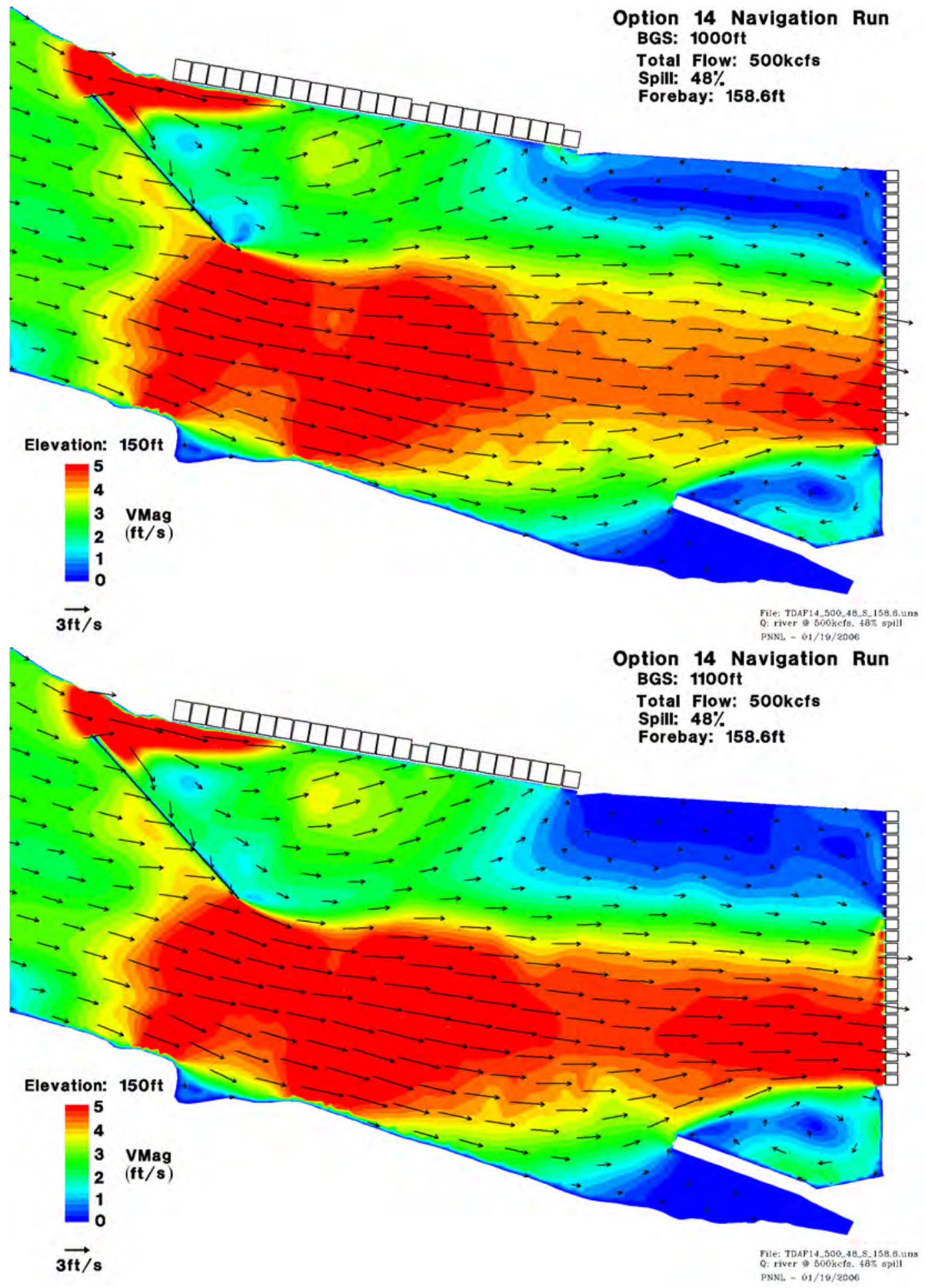

Figure D.5. The BGS simulation results for a Total River of $500 \mathrm{kcfs}$ with $48 \%$ spill for a 1000-ft length (top), 1100-ft length (bottom). 